\title{
PALEOCEANOGRAPHIC HISTORY OF THE SEYMOUR-BELIZE INLET COMPLEX, BRITISH COLUMBIA, CANADA, THROUGH THE LAST 1100 YEARS BASED ON FORAMINIFERAL DATA
}

Natalia Vázquez Riveiros

B. Sc., Universidade de Vigo, Spain, 2000

\begin{abstract}
A THESIS SUBMITTED IN PARTIAL FULFILLMENT OF THE REQUIREMENTS FOR THE DEGREE OF MASTER OF SCIENCES
\end{abstract}

in

THE FACULTY OF GRADUATE STUDIES AND RESEARCH

(Department of Earth Sciences)

\author{
CARLETON UNIVERSITY \\ OTTAWA-CARLETON GEOSCIENCE CENTRE
}

April, 2006

@2006, Natalia Vázquez Riveiros 


$\begin{array}{ll}\begin{array}{l}\text { Library and } \\ \text { Archives Canada }\end{array} & \begin{array}{l}\text { Bibliothèque et } \\ \text { Archives Canada }\end{array} \\ \begin{array}{l}\text { Published Heritage } \\ \text { Branch }\end{array} & \begin{array}{l}\text { Direction du } \\ \text { Patrimoine de l'édition }\end{array} \\ \begin{array}{l}\text { 395 Wellington Street } \\ \text { Ottawa ON K1A 0N4 } \\ \text { Canada }\end{array} & \begin{array}{l}\text { 395, rue Wellington } \\ \text { Ottawa ON K1A ON4 } \\ \text { Canada }\end{array}\end{array}$

Your file Votre référence ISBN: 978-0-494-16504-1 Our file Notre référence ISBN: 978-0-494-16504-1

NOTICE:

The author has granted a nonexclusive license allowing Library and Archives Canada to reproduce, publish, archive, preserve, conserve, communicate to the public by telecommunication or on the Internet, loan, distribute and sell theses worldwide, for commercial or noncommercial purposes, in microform, paper, electronic and/or any other formats.

The author retains copyright ownership and moral rights in this thesis. Neither the thesis nor substantial extracts from it may be printed or otherwise reproduced without the author's permission.
AVIS:

L'auteur a accordé une licence non exclusive permettant à la Bibliothèque et Archives Canada de reproduire, publier, archiver, sauvegarder, conserver, transmettre au public par télécommunication ou par l'Internet, prêter, distribuer et vendre des thèses partout dans le monde, à des fins commerciales ou autres, sur support microforme, papier, électronique et/ou autres formats.

L'auteur conserve la propriété du droit d'auteur et des droits moraux qui protège cette thèse. $\mathrm{Ni}$ la thèse ni des extraits substantiels de celle-ci ne doivent être imprimés ou autrement reproduits sans son autorisation.
In compliance with the Canadian

Privacy Act some supporting forms may have been removed from this thesis.

While these forms may be included in the document page count, their removal does not represent any loss of content from the thesis.
Conformément à la loi canadienne sur la protection de la vie privée, quelques formulaires secondaires ont été enlevés de cette thèse.

Bien que ces formulaires aient inclus dans la pagination, il n'y aura aucun contenu manquant.

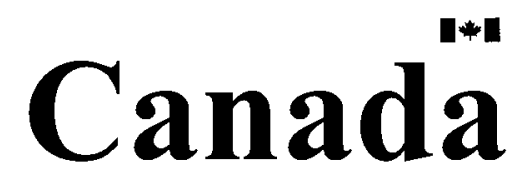




\begin{abstract}
Foraminiferal and thecamoebian faunas from the Seymour-Belize Inlet Complex (SBIC), a fjord network situated in the mainland coast of British Columbia, were studied to asses climatic cycles and trends impacting the area through the $\sim \mathrm{AD}$ 900 - AD 2002 interval. Through cluster analysis, ordination methods, and the use of foraminiferal-based transfer functions, a period of weak estuarine circulation due to diminished precipitation, with feeble, infrequent incursions of ocean water into the basin was recognized to have impacted the area during the Medieval Warm Episode (MWE), which occurred here between AD 900 and 1495. Conversely, in the years between AD 1574 and 1943, a very strong estuarine circulation developed, with frequent renewals of the bottom waters by cold, oxygenated ocean currents enhanced by a strong precipitation pattern. This period is concomitant with the onset of the Little Ice Age (LIA) in western Canada. A reversal towards weaker estuarine flow has happened since AD 1943. A detailed taxonomy of the foraminiferal fauna of the area is also presented, which includes the description of Eggerella belizensis n. sp.
\end{abstract}




\section{Acknowledgements}

First of all, I would like to thank my supervisor, Dr. Tim Patterson, for allowing me to participate in his research project at Carleton University. His help and guidance made this thesis what it is, and for that I am thankful. Rick Thomson and Cindy Wright, from the Pacific Geoscience Centre (Sydney, BC), provided very helpful comments on the discussion; R. Thomson kindly allowed me to use his oceanographic data for Belize Inlet and Alison Sound. J.P. Guilbault, from BRAQStratigraphie (Montreal, QC), aided with the identification of foraminifera. Dr. M. Forbes, Dr. I. Clark and Dr. P. Gammon were as kind as to be present as my thesis committee.

I would like to acknowledge the financial support of Fundación "La Caixa" and the Canadian Council of Graduate Studies, which provided me with funding for the first year of my studies. A Natural Sciences and Engineering Research Council Discovery Grant and Canadian Foundation for Climate and Atmospheric Sciences grant to Dr. Patterson funded the research. Mike's Place provided funding for food and shelter during the last two years, a grad bar truly helping grad students...

On a more personal level, thanks (?) to Sam, without you I wouldn't be here... Many thanks to Delma Holan as well, for her support and handy ideas all this time. I've made many friends during the last three years; it would be impossible to name them all: Andy, Davin, Jen, Lameed, and all the others that offered their sympathy. Stephanie Kale has walked the "thesis path" together with me, her support, encouragement, and late calls for a beer, have made it all enjoyable, despite the pressure.

My friends and family from Spain have been with me every minute, and their support has kept me going. Many thanks especially to my parents, Maria and Pepe, and my brother Diego. This thesis is dedicated to you.

A mis padres. 


\section{Table of contents}

ABSTRACT ........................................................................................................................................... II

ACKNOWLEDGEMENTS …..............................................................................II

TABLE OF CONTENTS ..........................................................................................IV

LIST OF FIGURES …......................................................................................... VII

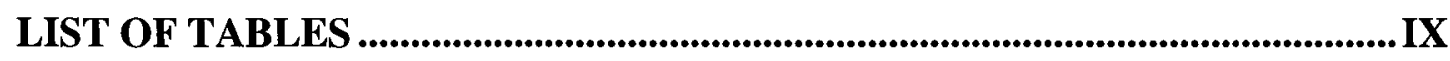

LIST OF PLATES ……..........................................................................................................

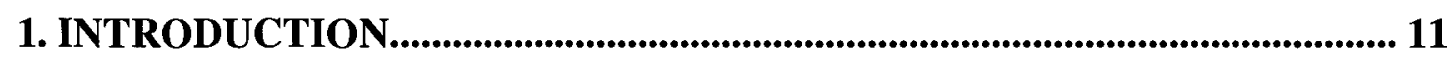

2. GEOGRAPHIC SETTING ........................................................................... 12

3. REGIONAL CLIMATE................................................................................................. 12

4. OCEANOGRAPHIC SETTING …................................................................. 15

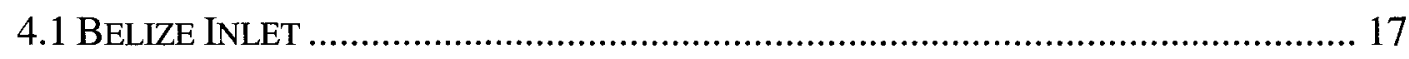

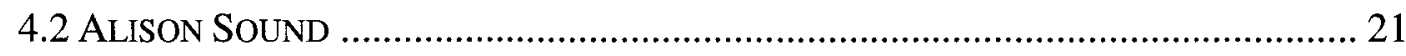

5. PREVIOUS WORK......................................................................................................... 24

6. METHODS AND MATERIALS .............................................................................. 25

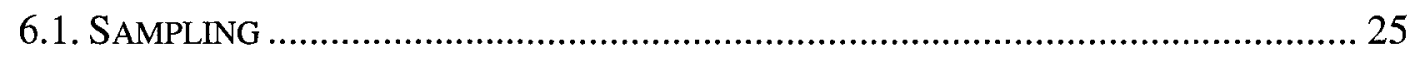

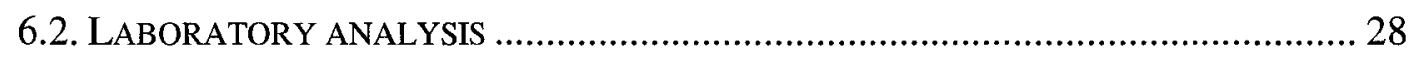

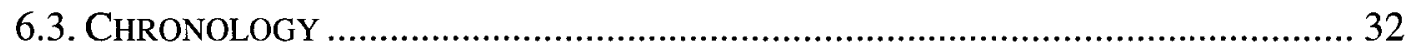

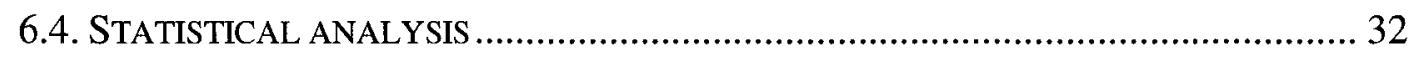




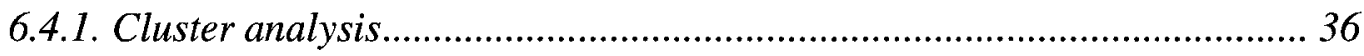

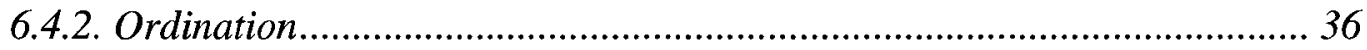

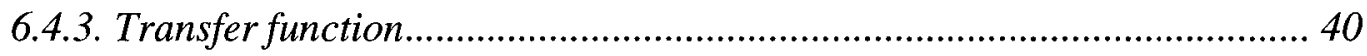

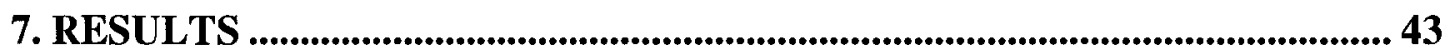

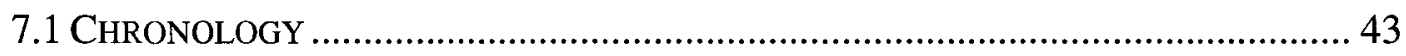

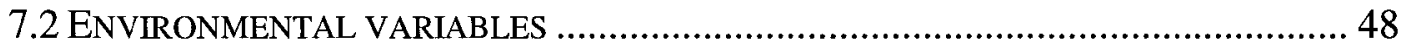

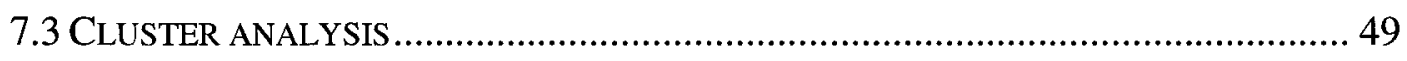

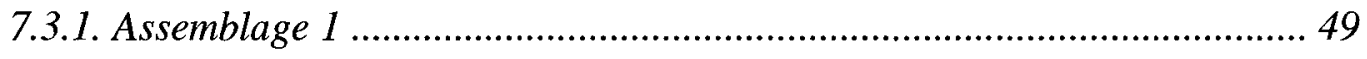

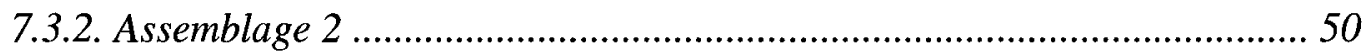

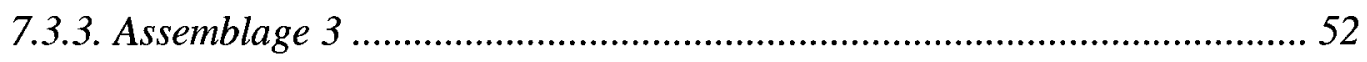

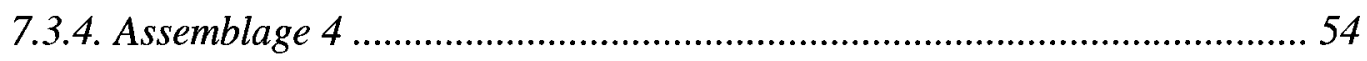

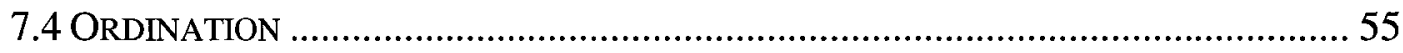

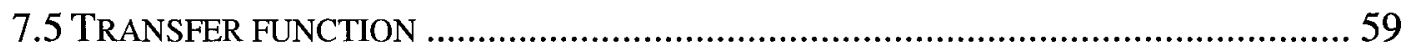

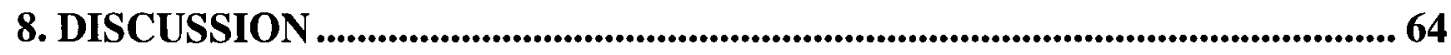

8.1. MODERN DISTRIBUTION OF FORAMINIFERA IN THE SBIC .............................. 64

8.2. PAleoceanographic Changes IN Belize Inlet ( AD 900 - AD 2002) ...... 67

Thecamoebian Distribution in FC04 ................................................ 75

8.3. PALEOCLIMATIC INTERPRETATION ........................................................ 76

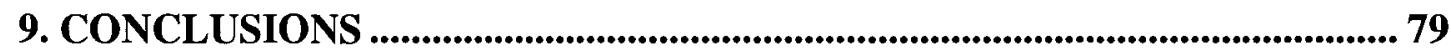

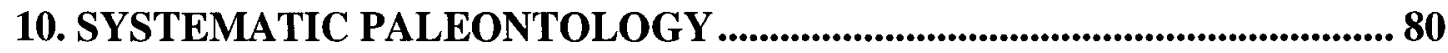

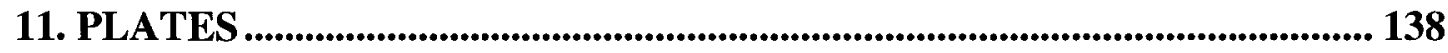




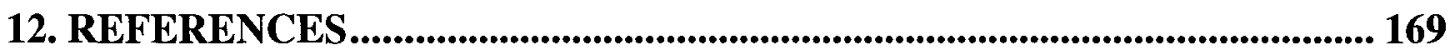

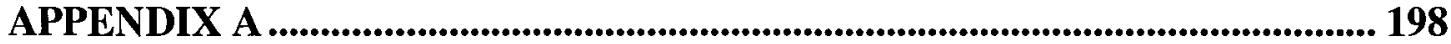

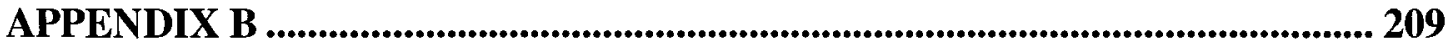




\section{List of figures}

Figure 1: location of study area and sampling site. (a) Map of Canada. (b) Map of Vancouver Island and mainland coastal British Columbia. (c) Map of the Seymour-Belize Inlet Complex, with sampling sites marked with stars.

Figure 2: longitudinal profiles of Belize Inlet, with bathymetric contour. Top, temperature in ${ }^{\circ} \mathrm{C}$. Middle, dissolved oxygen concentration, in $\mathrm{mL} / \mathrm{L}$. Bottom, salinity, in practical salinity units (psu). Y-axis is depth, in $\mathrm{m}$. X-axis is distance from the mouth of the inlet, in $\mathrm{km}$. Vertical lines represent sampling stations. Color scale for each unit at the right side of each profile. .18

Figure 3: longitudinal profiles of Alison Sound, with bathymetric contour. Top, temperature in ${ }^{\circ} \mathrm{C}$. Middle, dissolved oxygen concentration, in $\mathrm{mL} / \mathrm{L}$. Bottom, salinity, in practical salinity units (psu). $\mathrm{Y}$-axis is depth, in $\mathrm{m}$. $\mathrm{X}$-axis is distance from the mouth of the inlet, in $\mathrm{km}$. Vertical lines represent sampling stations. Color scale for each unit at the right side of each profile. Station BE5 in Belize Sound is included at the left side of each diagram .22

Figure 4: stratigraphic column of freeze core FC04, from Belize Inlet. Samples used for cluster analysis are shown. Colors indicate different assemblages from cluster analysis. Dates from ${ }^{210} \mathrm{~Pb}$ chronology, in yr $\mathrm{AD} ; *$ denotes radiocarbon dates, in cal $\mathrm{yr} \mathrm{AD}$; italics indicate extrapolation from ${ }^{210} \mathrm{~Pb}$ chronology, in yr $\mathrm{AD}$. .29

Figure 5: age-depth model for calibrated radiocarbon dates. The sediment accumulation rate derived from the slope of the linear regression line is $1.242 \mathrm{~mm} / \mathrm{yr}$. Horizontal error bars represent the range of ages defined by the probability distribution of the samples' true age.

Figure 6: Q-mode vs. R-mode cluster diagram for FCO4 and surface samples, with fractional abundances of the species indicated by symbols. . .53

Figure 7: CCA triplot, representing the relation between the faunal distribution in the SBIC and temperature, oxygen and silicate. Filled circles represent species; open circles represent samples. 
Figure 8: oxygen (Estimated OXYGEN) and temperature (Estimated TEMP) reconstructions from foraminiferal transfer functions, and foraminiferal and thecamoebian stratigraphy of core FC04. Age down core corresponds to ${ }^{210} \mathrm{~Pb}$ extrapolation. A: stratigraphic zone corresponding to Assemblage 1 of the cluster analysis. B: stratigraphic zone corresponding to Assemblage 2 of the cluster analysis. C: stratigraphic zone corresponding to Assemblage 3 of the cluster analysis. D: stratigraphic zone corresponding to Assemblage 4 of the cluster analysis. The X-axis values for the species are given in fractional abundances. The $\mathrm{X}$-axis values for oxygen and temperature are given in $\mathrm{mL} / \mathrm{L}$ and ${ }^{\circ} \mathrm{C}$, respectively. Buccella: Buccella species; Ccrassa: C. crassa; Cexmagna: C. excavatum forma magna; Cexclav: C. excavatum forma clavata; Cexex: C. excavatum forma excavata; Cforam: C. foraminosum; Csubglob: C. cf. subglobosum; Eggerel: Eggerella species; Evitrea: E. vitrea; Hbradyi: H. bradyi; Nlabrad: N. labradorica; Rturb: $R$. turbinatus; Sbiform: $S$. biformis; Sfeylin: S. feylingi; Thecam: thecamoebian species. 


\section{List of tables}

Table 1: water depth, latitude and longitude of sediment-water interface samples and freeze core FC04 used on this study .27

Table 2: values of environmental variables measured at the sediment-water interface samples. The values marked with * represent values imputed with linear regression using the values for the rest of the stations in the same inlet. .38

Table 3: values for the Pearson correlation coefficient for the environmental variables. **: Correlation is significant at the 0.01 level (2-tailed).*: Correlation is significant at the 0.05 level (2-tailed). 40

Table 4: results of the ${ }^{210} \mathrm{~Pb}$ analysis, showing the ages at different depths on the top section of FC04, and their standard deviation. The sedimentation rate calculated from these dates is $1.52 \mathrm{~mm} / \mathrm{yr} .44$

Table 5: radiocarbon ages and calibrated ages (years $\mathrm{AD}$ ) for the two radiocarbon samples sent to Isotrace Lab. The calibration was done using the program CALIB v. 5.0.1., with the calibration dataset Intcal.04. The calibrated results are reported at the $95.5 \%(2 \sigma)$ confidence interval. The median probability ages are rounded to the nearest year. . .46

Table 6: values for the Canonical Correspondence Analysis (CCA) of the surface samples . .56

Table 7: performance of the two regression models, WA and WA(Tol), with classical (Cla) and inversion (Inv) deshrinking, for the oxygen and temperature reconstructions of the foraminiferal fossil set of FC04. Values in $\mathrm{mL} / \mathrm{L}$ and ${ }^{\circ} \mathrm{C}$, respectively. . .60 


\section{List of plates}

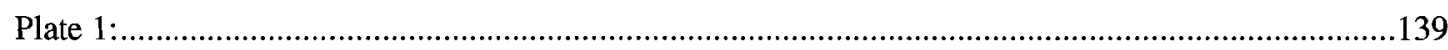

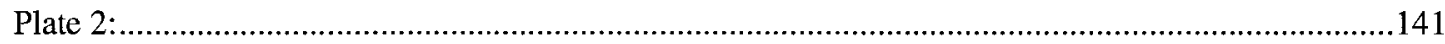

Plate 3:

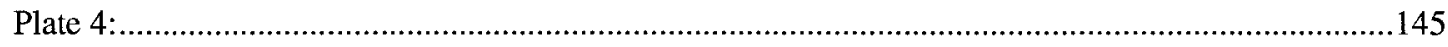

Plate 5:

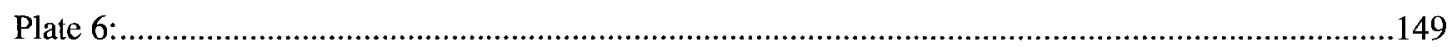

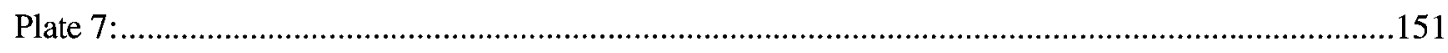

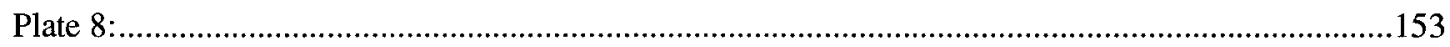

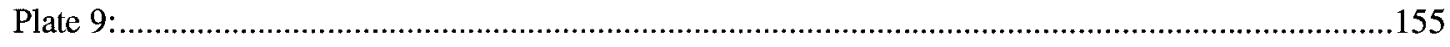

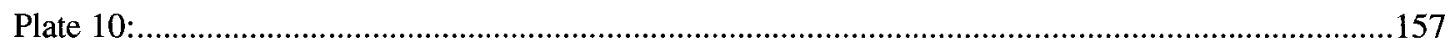

Plate 11:

Plate 12:

Plate 13:

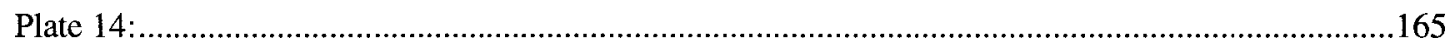

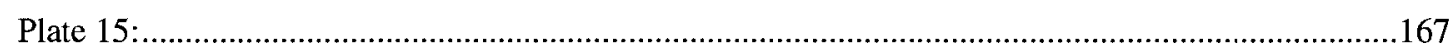




\section{Introduction}

Coastal mainland British Columbia is a geographically complex, vast area, characterized by a mountainous terrain punctuated by numerous fjords that reach far inland. The Seymour-Belize Inlet Complex (SBIC) is one of these fjord systems. The SBIC is the target of an ongoing multidisciplinary project that is mandated to assess climate cycles and trends through the Holocene. Assessing paleoceanographic changes based on variation in foraminiferal faunas over time is an important component of this research. Unfortunately, there is very little baseline foraminiferal distributional data available for this region that can be used to interpret Holocene foraminiferal faunas (e.g., Guilbault et al., 1997; Guilbault et al., 2003; Jonasson and Patterson, 1992; Patterson, 1993; Patterson and Cameron, 1991a; Patterson and Cameron, 1991b; Schafer et al., 1989; Vázquez Riveiros et al., 2006). Thus the primary purpose of the research presented here is to:

1) document and characterize the modern distribution of foraminiferal faunas from the SBIC;

2) use this data to develop a training set to interpret the observed foraminiferal faunas recovered from a freeze core that was collected near the mouth of the SBIC and deposited over the last $\sim 1000$ years; and

3) to provide baseline data that will be used by other researchers to interpret cores deposited through the Holocene in the SBIC. 


\section{Geographic setting}

The SBIC is a network of long and deep steep-sided fjords on the central coast of mainland British Columbia (Figure 1), about $40 \mathrm{~km}$ northeast of Port Hardy, Vancouver Island. The complex lies between latitudes $50^{\circ} 50.2^{\prime} \mathrm{N}$ and $51^{\circ} 10.6^{\prime} \mathrm{N}$, and longitudes $126^{\circ} 30.2^{\prime} \mathrm{W}$ and $127^{\circ} 40.5^{\prime} \mathrm{W}$, and opens to Queen Charlotte Sound in the Pacific Ocean via Slingby and Schooner Channels.

The main arms of the complex are the east-west trending Seymour and Belize inlets, which reach inland about 70 and $50 \mathrm{~km}$ respectively. Alison Sound is a smaller inlet that extends $20 \mathrm{~km}$ off the northern margin of Belize Inlet, in a northeasterly direction before turning towards the east. Small rivers and creeks provide freshwater to the heads of all inlets in the SBIC, with Belize Creek and Waamtx Creek in Belize Inlet, and Waump Creek in Alison Sound being amongst the most important streams. The freshwater input of these rivers, together with numerous waterfalls along the inlets, peaks during the snow-melt period that starts in May and plays an important role in circulation in the SBIC (Thomson, 1981).

\section{Regional climate}

The climate coastal British Columbia is mild, with winter temperatures typically remaining above the freezing point accompanied by frequent rains, and warm days and cool nights in summer (Hare and Thomas, 1979). Mean annual 

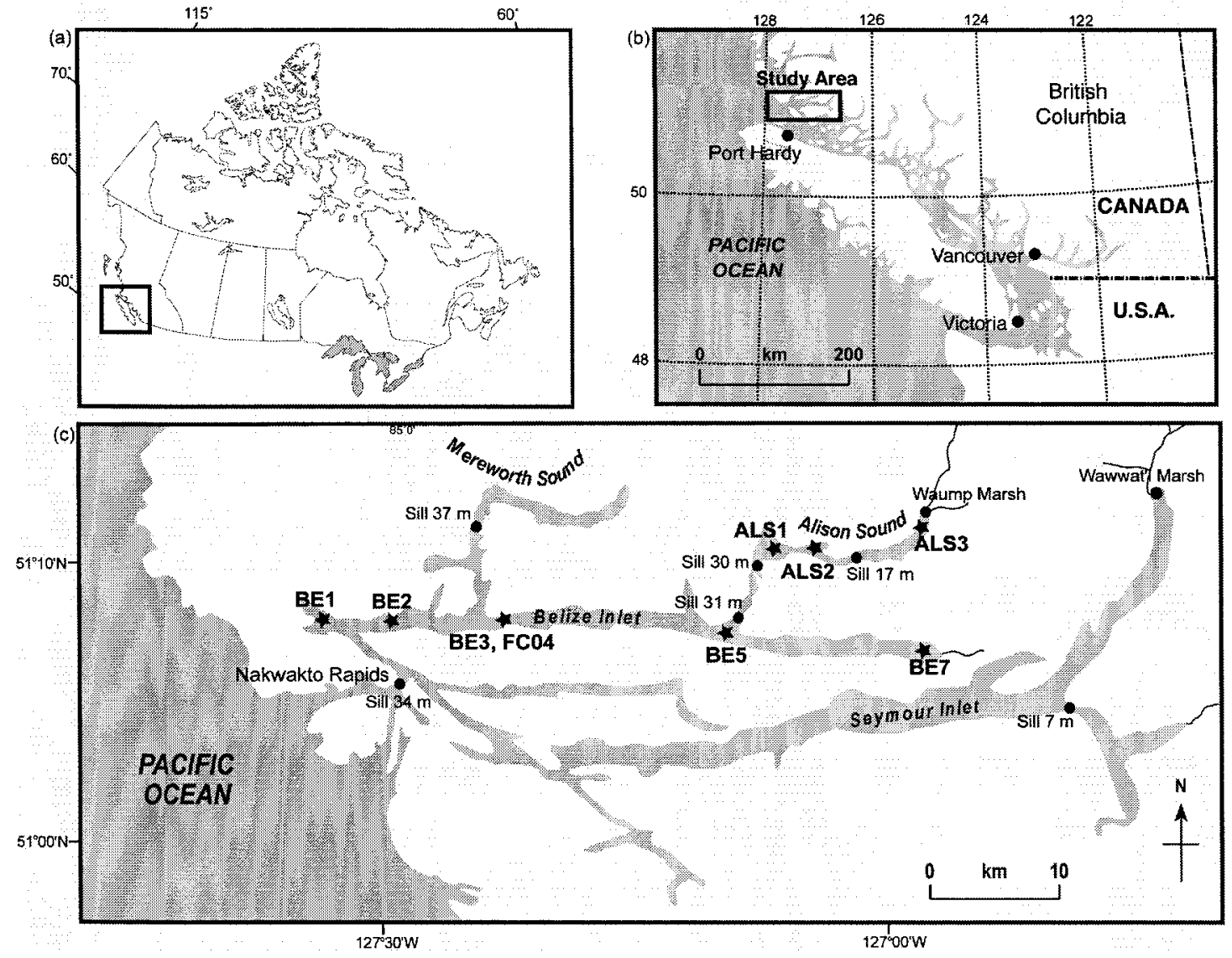

Figure 1: location of study area and sampling site. (a) Map of Canada. (b) Map of Vancouver Island and mainland coastal British Columbia. (c) Map of the Seymour-Belize Inlet Complex, with sampling sites marked with stars. 
precipitation in the SBIC region is $3120 \mathrm{~mm}$ (range between $2009 \mathrm{~mm}$ and 3943 $\mathrm{mm}$ ), with an average annual temperature of $9.1^{\circ} \mathrm{C}$ (range between $5.4^{\circ}$ to $9.4^{\circ} \mathrm{C}$ ) (Green and Klinka, 1994).

Weather systems are seasonally dominated by the counter-clockwise circulating winds that accompany the Aleutian Low (AL) in winter and the clockwise circulating winds that occur with the North Pacific High (NPH) in summer. The relative position of these pressure systems is in turn influenced by shifts in the positioning of the jet stream (Ware and Thomson, 2000), that is influenced by sunspot cycles (Harmeed and Lee, 2003). The mouth of the SBIC is situated at the northern border of the Coastal Upwelling Domain (CUD) (Ware and McFarlane, 1989), where from May through September the northwesterly winds of the NPH displace warm water from the surface, promoting the upwelling of cold, nutrient-rich deep water that greatly enhances productivity in the surface layers. However, because the SBIC is at the northern boundary of the domain and opens to Queen Charlotte Sound instead of the open ocean, the influence of upwelling within the SBIC is virtually nil as compared to more exposed inlets on the west coast of Vancouver Island (e.g., Patterson et al., 2004b). Another type of upwelling occurs when a deep current encounters an underwater ridge that deflects it towards the surface (Thomson, 1981). This localized effect can have a very important influence on circulation in fjord systems such as the SBIC, which have pronounced sills at their entrances.

The AL is also responsible for the frequency and intensity of winter storms that promote cold weather and precipitation at this time of the year (Beamish et al., 1999; Chang and Patterson, 2005; Miller et al., 1994). Storms that form in the ocean 
on the southern edge of the $\mathrm{AL}$ travel northeast towards southern $\mathrm{BC}$ and northern Washington. At the same time, storms that form in the Gulf of Alaska move southeastward towards the coast, due to the clockwise circulation of the Alaska Gyre. Therefore, the coast of $\mathrm{BC}$ receives the highest amount of precipitation when the $\mathrm{AL}$ dominates circulation patterns in the North Pacific (Cayan and Peterson, 1989; Trenberth and Hurrel, 1995). During the spring and summer, when the NPH moves northward and the AL dissipates, less precipitation and clear skies are the dominant features in the area (Chang and Patterson, 2005; Thomson, 1981). Although the position and strength of the AL is characterized by great interannual variability, there have been periods where a strong westward position dominated at longer time scales (Spooner et al., 2003). Cycles of 2, 11, 20 - 30, 50 - 70, 150 and $200-500$ years have been observed in the region that may in part be accounted for by the varying influence of the AL and NPH (Chang and Patterson, 2005; Hu et al., 2003).

\section{Oceanographic setting}

Maximum depths within the SBIC are greater than $600 \mathrm{~m}$ in Seymour Inlet, $300 \mathrm{~m}$ in Belize Sound, and $150 \mathrm{~m}$ in Alison Sound. Oxygen concentrations in the bottom waters of the SBIC range from high oxic in the main arms (more than 6 $\mathrm{mL} / \mathrm{L}$ ) to anoxic conditions in Alison Sound .

An important characteristic of these bathymetrically $\mathrm{U}$-shaped basins is the presence of sills in most of them, formed by crushed rock and silt that were deposited as moraines by advancing glaciers. The sills reduce the input of oxygen-rich ocean water into the inlets, which together with a low-salinity wedge caused by riverine 
input at the surface, results in reduced mixing between surface and bottom waters, forming a stratified water column. It is also typical in these partially mixed estuaries to have the salinity of the surface layer increase down-inlet away from freshwater sources, and the salinity of bottom waters increasing slightly towards the head of the inlet (Pickard and Stanton, 1980; Thomson, 1981). The restricted circulation in these systems enhances the trapping of organic and inorganic material borne by runoff, making these environments effective nutrient traps. Disturbance at the sediment water interface is minimized due to the high residence time and slow circulation of the bottom water, thus creating an ideal setting for paleoenvironmental research.

The main sill at the mouth of the SBIC, the Nakwakto Rapids, is only $34 \mathrm{~m}$ deep and $300 \mathrm{~m}$ wide, and forms a major bottleneck during tidal cycles (Department of Energy, 1979) (Figure 1). During the ebb tide current flow through Nakwakto Rapids can reach velocities of $8 \mathrm{~m} / \mathrm{s}$, making it one of the strongest tidal currents in the world (Thomson, 1981). This tidal constriction at the Nakwakto Rapids is so restrictive that it is impossible for sea level with the SBIC to equalize with that of Queen Charlotte Sound during ebb tidal flow, resulting in a tidal range of more than 2 $\mathrm{m}$ in Queen Charlotte Sound and a maximum of only $1.3 \mathrm{~m}$ in the interior of the SBIC (Fisheries and Oceans, 2003).

There are three sills in Alison Sound (Figure 1), which further restrict circulation into this inlet. The outermost one, located at the juncture of Alison Sound with Belize Inlet, is $31 \mathrm{~m}$ deep; the second, just inside the mouth of Alison Sound, is $30 \mathrm{~m}$ deep, while the last sill, located near the head of the inlet, is only $17 \mathrm{~m}$ deep. 


\subsection{Belize Inlet}

Belize Inlet is a low runoff fjord with an average fresh water discharge of 80 $\mathrm{m}^{3} / \mathrm{sec}$. The level of runoff through the year closely mirrors the seasonal coastal rainfall pattern, with values above average in the spring and winter months, and below average between July and September. The influence of stored runoff (glaciers, snow fields) is minimal in the SBIC (Pickard, 1961).

The penetration of cold oceanic waters into the SBIC is enhanced by the presence of strong estuarine circulation (Pickard, 1961; Thomson, 1981), that in this case is strongly influenced by the seasonal variability in local precipitation patterns. Rainfall acts as a source of low density water to the surface layer, stabilizing the stratification and increasing the horizontal flux of the river runoff as the freshwater moves towards the sea (e.g., Gibbs et al., 2000). The net motion of the surface layer in these environments is always directed towards the ocean as an immediate consequence of the discharge of freshwater into the heads of the inlets. This freshwater creates a low salinity surface layer, enhanced at the head and more diluted towards the mouth, that gains volume and velocity as it entrains saline water from below on its movement towards the sill. This unidirectional flow is superimposed on the tidal current, increasing the speed of the flood tide and decreasing that of the ebb (Pickard, 1961).

As a result of the outflow of surface layer, a subsurface inflow of oceanic waters must take place, in order to preserve the net volume of the inlet (Thomson, 1981). This influx of ocean waters was monitored in April 2002 by researchers aboard the CCGS Vector who noted a prominent plume characterized by colder 

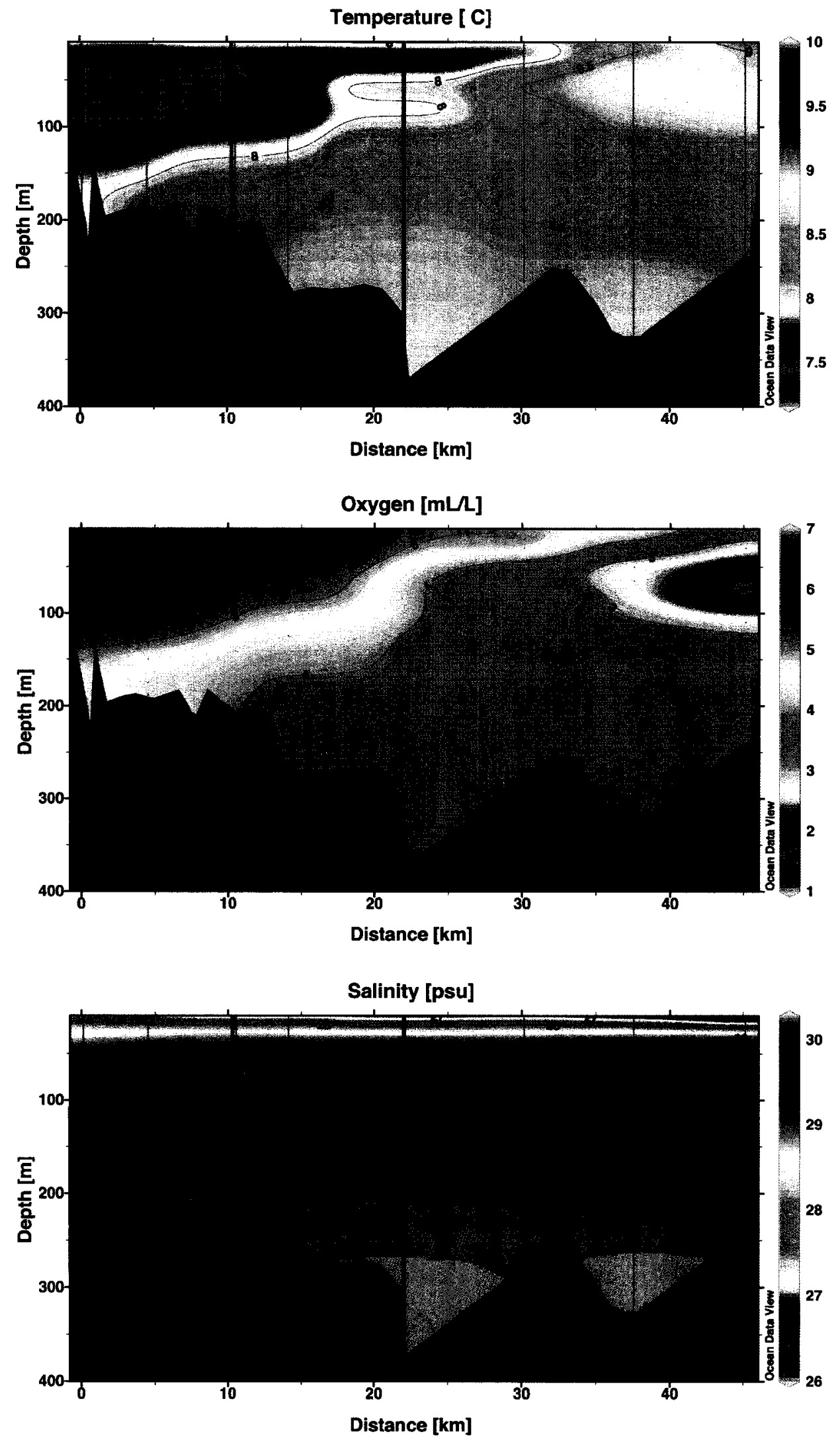
temperatures and high dissolved oxygen concentration at the mouth of Belize Inlet

(Figure 2). The density in the inlets is mainly determined by salinity (Pickard, 1961) so that the more saline, and hence denser, ocean water sinks to the bottom of the inlet effectively "renewing" the deep layer and hindering the development of anoxic conditions. Whether the cold, oxygenated ocean water fills the deep basin, displacing the old water, or is interlayered in the water column, depends on its density relative to the density of the waters of the SBIC (Gillibrand et al., 1996; Neumann et al., 1997). Judging from observations made in April 2002, the density difference between the two water masses was not high enough to promote a renewal through the entire water column, so the oceanic water can be seen as a layer at an average depth of $100 \mathrm{~m}$ (Figure 2).

Time-series measurements carried out in other fjords systems, especially in Europe, have recognized a good correlation between the input of salty oceanic water and oxygen input below the halocline (Neumann et al., 1997). The frequency of deep water renewal in these fjords varies considerably, ranging from a few weeks up to several years (e.g., Gillibrand et al., 1996; Gustafsson and Nordberg, 2000; Lassen et al., 2004; Neumann et al., 1997).

The brackish layer at the surface of Belize Inlet (Figure 2) has a minimum value of $26 \%$ close to the head of the inlet. This layer is restricted to the top $25 \mathrm{~m}$ of the water column, with deeper areas of the inlet being characterized by salinities of $30 \%$. Since the lower salinity surface layer is shallower than the sill depth $(34 \mathrm{~m})$ the flow of oceanic water into the fjord is constrained but not completely blocked, as is 
the case in many fjords elsewhere (e.g., scottish lochs; Gillibrand et al., 1996; Murray et al., 2003). Bottom oxygen concentrations in the inlet range between 3 and $4 \mathrm{~mL} / \mathrm{L}$.

\subsection{Alison Sound}

Oceanographic conditions in Alison Sound, where circulation is more restricted, are quite different from those observed in Belize Inlet (Figures 1, 3). A low salinity surface plume $(26.5 \%$ - $28 \%$ ) is present above a bottom water layer characterized by a constant salinity of $28.5 \%$. The reduced salinity levels at depth relative to those measured in Belize Inlet reflect the reduced oceanic influence within Alison Sound, although a small tongue of colder oceanic water was observed to penetrate a short distance into the sound in April 2002 (Figure 3). In contrast, temperature profiles measured in Alison Sound tend to be more homogeneous than those observed in Belize Inlet, which may in part be related to the shallower depth of the sound.

Oxygen concentration values in excess of $4 \mathrm{~mL} / \mathrm{L}$ characterize the surface water mass of Alison Sound, which easily penetrates from Belize Inlet past both the first and second sills at the mouth of the sound. These sills impact the circulation of deeper water masses, though. Despite there being a lower salinity variation between surface and bottom waters in Alison Sound than observed in Belize Inlet, bottom water oxygen levels of $<2 \mathrm{~mL} / \mathrm{L}$ prevail. At Station ALS3, which is beyond the third and shallowest sill in Alison Sound (17 m; Figure 1) circulation is further restricted, resulting in minimum oxygen values of $0.06 \mathrm{~mL} / \mathrm{L}$. 

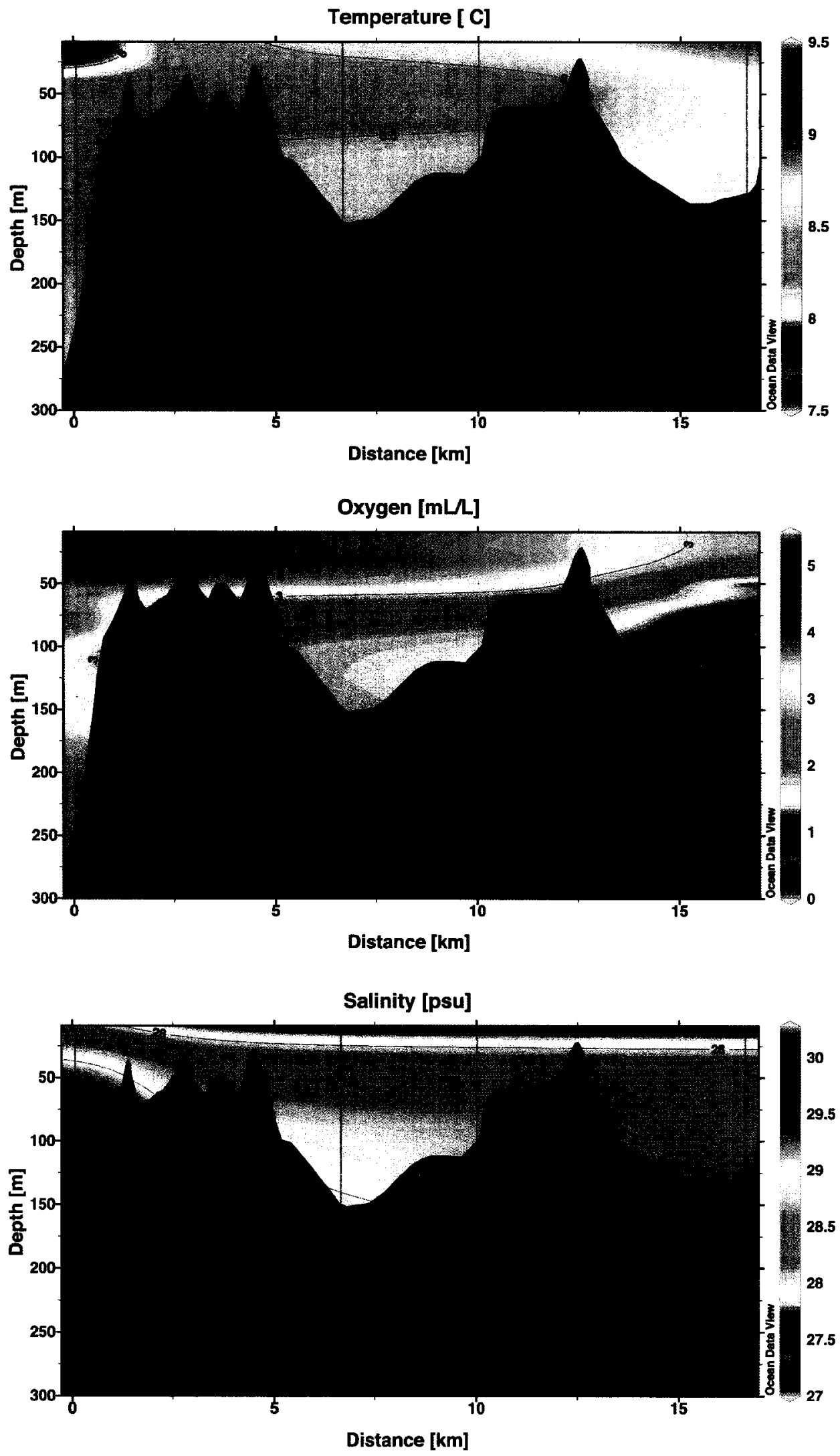


\section{Previous work}

There has been extensive research on foraminifera as paleoecological proxies along the west coast of North America, although very few studies on the distribution of modern foraminifera have been carried out in coastal mainland British Columbia waters. The first published descriptive study on Recent foraminifera from off the coast of British Columbia was that of Cushman (1925), who described a few Recent species found in shallow waters in Queen Charlotte Sound. Cockbain (1963) described two main faunal divisions in Juan de Fuca and Georgia Straits, and linked those assemblages with the physical oceanography of the area. McCulloch (1977) described and illustrated the fauna found in several samples from Vancouver Harbor during her extensive taxonomic research of foraminifera from the Eastern Pacific. Jones and Ross (1979) related the seasonal distribution of foraminifera with different ecological factors in Samish Bay, Washington. A key descriptive study of foraminifera found in coastal British Columbia waters was the illustrated atlas of common benthic foraminifera produced by Patterson et al., (1998).

Several studies have focused on the continental shelf and on the Strait of Georgia in order to determine the Holocene climate history of the area (Guilbault et al., 1997; Guilbault et al., 2003; Mathewes et al., 1993; Patterson, 1993)

More relevant to this study has been the increase in foraminiferal-based paleoceanographic research on inlets and fjords, especially from Vancouver Island. Saanich Inlet, an anoxic fjord on the southeast coast of Vancouver Island has been extensively researched. Blais-Stevens and Patterson (1998) identified five foraminiferal biofacies in sediment-water interface samples that were mainly defined 
by water circulation within the fjord. Foraminifera were also used in Saanich Inlet to identify environmental changes in the last 14000 years from ODP sites 1033B and 1034B (Kumar and Patterson, 2005; Patterson and Kumar, 2002). In Effingham Inlet, on the southwest side of Vancouver Island, different foraminiferal associations were found to be controlled by varying levels of oxygen content in the bottom waters (Patterson et al., 2000). Knight and Bute Inlets, south of the SBIC, were the sites of the only previous study on foraminifera carried out along the coastal mainland (Schafer et al., 1989). These researchers recognized low-diversity arenaceous foraminifera assemblages at the head of both inlets that were replaced by calcareous assemblages near the mouths due to the increasing influence of marine water from the continental shelf (Schafer et al., 1989).

The only previous foraminiferal study carried out in the SBIC was an investigation of the distribution of foraminifera and thecamoebians in two marshes at the heads of Alison Sound and Belize Inlet (Vázquez Riveiros et al., 2006, submitted). However, there have been other recent studies in the SBIC using different micropaleontological proxies (diatoms, pollen) to quantify the nature of climate and sedimentary variability through the Holocene (Galloway, 2006; Patterson et al., 2006, submitted; Wigston, 2006).

\section{Methods and materials}

\subsection{Sampling}

Sampling took place during a research cruise to the SBIC by the CCGS Vector in April 2002. Eight sediment-water interface samples were collected using a Smith- 
Mac grab sampler in Belize Inlet (BE1, BE2, BE3, BE5, BE7) and Alison Sound (ALS1, ALS2 and ALS3; Figure 1; Table 1). In addition, one $145 \mathrm{~cm}$ freeze core, FC04, was collected in Belize Inlet at a water depth of $274 \mathrm{~m}$ (Figure 1). Subsequent to collection, the grab samples were treated with alcohol as a preservative, stored in plastic vials, and shipped by air to Carleton University, where they were stored prior to processing in a cool room at $+4^{\circ} \mathrm{C}$.

The freeze core was stored in a freezer aboard the CCGS Vector until the vessel returned to port, at which point the core was transported to the Pacific Geoscience Centre (PGC) in Sidney, BC. At the PGC, the outer layer of the freeze core was removed in situ to reduce the risk of contamination. The core was then subdivided longitudinally into $\sim 1 \times 2 \mathrm{~cm}$ subsections using a band saw, and then subdivided laterally to facilitate handling and x-raying. One complete set of freeze core subsections was transported frozen to Carleton University for subsequent analysis, where they were kept at a constant temperature of $-6^{\circ} \mathrm{C}$. Water property data profiles of pressure, temperature and transmissivity were measured at each grab and freeze core station (with the exception of BE3), using a Sea-Bird model SBE-911Plus Conductivity, Temperature, Density (CTD) instrument. In addition, bottle samples were obtained through the water column throughout the entire SBIC network using a standard CTD array to collect water property data such as photosynthetically active radiation (PAR), salinity, dissolved oxygen, nitrate plus nitrite, silicate and phosphate. Samples for salinity analysis were analyzed on a Guildline model 8410 Portasal Salinometers, standardized with IAPSO standard seawater. Oxygen analysis was carried out using an automated Winkler titration system, following the procedures of 


\begin{tabular}{cccc}
\hline & DEPTH & LATITUDE & LONGITUDE \\
\hline \hline BE1 & $(m)$ & $\left(^{\circ}\right)$ & $\left({ }^{\prime}\right)$ \\
BE2 & 225 & $51^{\circ} 7.79^{\prime} \mathrm{N}$ & $127^{\circ} 34.19^{\prime} \mathrm{W}$ \\
BE3 & 190 & $51^{\circ} 7.94^{\prime} \mathrm{N}$ & $127^{\circ} 30.38^{\prime} \mathrm{W}$ \\
BE5 & 290 & $51^{\circ} 7.78^{\prime} \mathrm{N}$ & $127^{\circ} 21.95^{\prime} \mathrm{W}$ \\
BE7 & 276 & $51^{\circ} 7.10^{\prime} \mathrm{N}$ & $127^{\circ} 8.82^{\prime} \mathrm{W}$ \\
ALS1 & 245 & $51^{\circ} 6.50^{\prime} \mathrm{N}$ & $126^{\circ} 55.72^{\prime} \mathrm{W}$ \\
ALS2 & 152 & $51^{\circ} 10.00^{\prime} \mathrm{N}$ & $127^{\circ} 5.13^{\prime} \mathrm{W}$ \\
ALS3 & 135 & $51^{\circ} 10.16^{\prime} \mathrm{N}$ & $126^{\circ} 2.48^{\prime} \mathrm{W}$ \\
FC04 & 135 & $51^{\circ} 10.02^{\prime} \mathrm{N}$ & $126^{\circ} 56.79^{\prime} \mathrm{W}$ \\
\hline
\end{tabular}

Table 1: water depth, latitude and longitude of sediment-water interface samples and freeze core FC04 used on this study. 
Carpenter (1965). Nutrient samples were analyzed frozen with a Technicon AAII autoanalyzer, following the method described by Barwell-Clarke and Whitney (1996)

\subsection{Laboratory analysis}

Examination of the grab samples in 2004 revealed no discernable deterioration. Samples from Alison Sound, where dysoxic conditions prevailed, were characterized by a slight sulfurous smell, as well as darker color. Ten $\mathrm{cm}^{3}$ aliquots were taken from each grab sample and wet sieved through a $63 \mu \mathrm{m}$ screen to retain foraminifera and a $500 \mu \mathrm{m}$ screen to remove coarse organic material. The samples were subsequently split into two fractions using a $125 \mu \mathrm{m}$ screen, dried under low heat $\left(50^{\circ} \mathrm{C}\right)$ in an oven and weighted. Splitting dry samples into fractions prior to quantitative analysis was done in order to avoid counting errors, as the focus of the microscope does not have to be continually changed (Schröder et al., 1987).

Freeze core FC04 was also taken out of the freezer in 2004 and inspected. As no visible disturbances were found on the surface, such as desiccation cracks or evidence of mold, it was deemed suitable for analysis. The freeze core was first Xrayed at the Altavista Animal Hospital so that any internal sedimentary structures or laminations could be detected. The sediments comprising the freeze core FC04 were very fine grained and soupy, and would have been impossible to recover using conventional coring methods. Two sections of the core, $80-85 \mathrm{~cm}$, and $93-104 \mathrm{~cm}$, were comprised of laminations that were clearly visible on the X-ray. The organic content of the core increased significantly below $75 \mathrm{~cm}$, and was characterized by an increasing proportion of fecal pellets down core (Figure 4). 


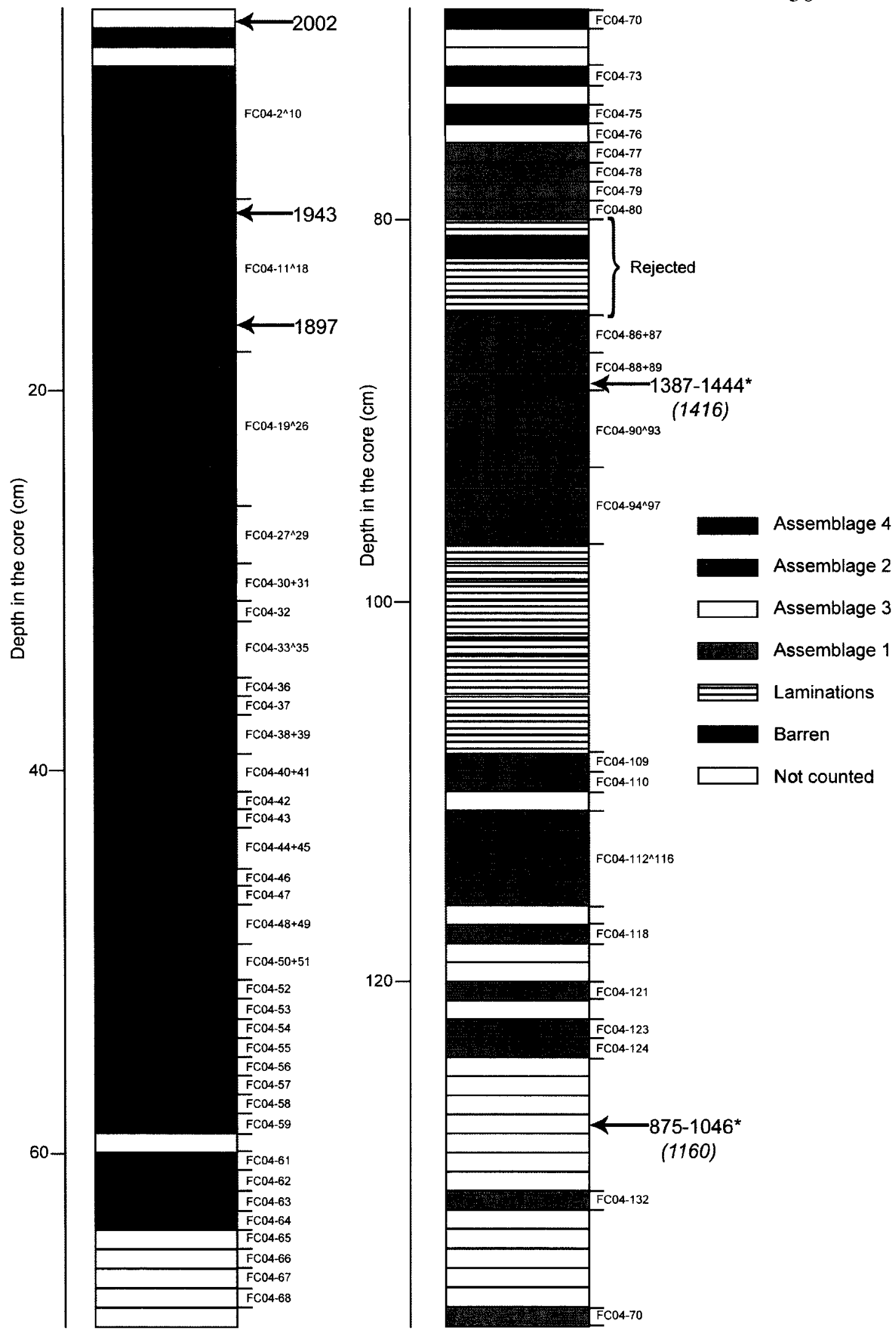


Based on the results of the visual analysis of the X-rays, the $0-138 \mathrm{~cm}$ portion of the core was subdivided using a ceramic knife into $121,1 \mathrm{~cm}$ thick samples for foraminiferal analysis. Ceramic knives are particularly useful for subdividing freeze cores, as the blade is extremely thin and sharp and permits the production of extremely thin slices when required. The $93-104 \mathrm{~cm}$ interval of the core was not subsampled as visual inspection of the $\mathrm{X}$-ray revealed that it was comprised of fine laminations. Based on examination of similar sedimentary intervals in other cores from the area, it was assumed that this interval was deposited under anoxic conditions and would therefore be barren of foraminifera.

With the exception of small portions of 15 aliquot samples that were removed for ${ }^{210} \mathrm{~Pb}$ dating (see below) all freeze core samples were subsequently sieved and processed using the same procedure as described above for the grab samples. These sediment-water interface grab and freeze core samples were quantitatively analyzed for foraminifera under an Olympus SZH10 stereo microscope. All foraminiferal specimens were picked and stored on gridded micropaleontological slides, and identified following the classification of Loeblich and Tappan (1987). Scanning electron photomicrographs were obtained using a JEOL 6400 Scanning Electron Microscope at the Carleton University Research Facility for Electron Microscopy (CURFEM). These digital images were converted into plates using Adobe (C) Photoshop 7.0 and Adobe (C) Illustrator 10.0.3 (Plates 1 to 15). 


\subsection{Chronology}

The ${ }^{210} \mathrm{~Pb}$ dating method is routinely used for the high resolution dating of marine sediments. Due to the short half-life of ${ }^{210} \mathrm{~Pb}$, it is limited to sediments deposited during the last 150 years (Appleby, 2001; Sorgente et al., 1999). However, as the method involves the dating of several samples over many centimeters of core, it is possible to determine sedimentation rates that may permit the estimation of ages in older sediments, particularly if corroborating ${ }^{14} \mathrm{C}$ dates are available down core, as was the case here. The fifteen subsamples removed for ${ }^{210} \mathrm{~Pb}$ dating were weighed wet and then dried in the oven at $50^{\circ} \mathrm{C}$ without sieving. After reweighing of the dry residue, the samples were stored in inert vials and sent to MyCore Scientific Inc. (Dunrobin, $\mathrm{ON}$ ) for measurement of ${ }^{210} \mathrm{~Pb}$ using alpha ray spectroscopy. Two additional subsamples from FCO4 were submitted for accelerated mass spectrometry (AMS) ${ }^{14} \mathrm{C}$ analysis at IsoTrace Laboratory (Toronto, $\mathrm{ON}$ ). The first sample from FC04, at $89 \mathrm{~cm}$ depth, was a wood fragment, while the second sample, at $128 \mathrm{~cm}$, consisted of bulk sediment, as no other dateable wood or shell were available lower in the core.

\subsection{Statistical analysis}

One hundred and one samples, eight from surface grabs and 93 from the freeze core, were utilized in the statistical analysis of this study. All eight surface grab samples were found to contain foraminifera. Of the 121 samples obtained from core FC04, 97 samples presented foraminifera, and four were found to be barren. Of the 41 samples not quantified for foraminifera (out of the $138 \mathrm{~cm}$ of the core), seven were 
utilized in chronostratigraphic dating, leaving no residue suitable for micropaleontological analysis. An additional eleven samples were comprised of laminated sediments deposited under anoxic conditions and were not processed, as examination of some laminated sediments from elsewhere in this core revealed laminated horizons to be either barren or to contain statistically insignificant foraminiferal populations. The remaining 23 samples not quantified were from portions of the core where there was very little stratigraphic change in the foraminiferal content. As little variability in faunal makeup occurred here, assemblage continuity was interpolated from adjacent samples.

Many samples were found to have low foraminiferal abundances, so an important first step was to determine which samples contained statistically significant populations. The probable error (pe) for each of the samples was calculated using the following formula:

$$
p e=1.96\left(\frac{s}{\sqrt{X_{i}}}\right)
$$

where $\mathrm{s}$ is the standard deviation of the population counts and $\mathrm{X}_{\mathrm{i}}$ is the number of counts at each sample i. A sample was judged to have a statistically significant population if the total counts for each sample were greater than the probable error. Fifty-seven samples were found to have statistically significant population, although 44 other samples, all from FC04 and representing more than $43 \%$ of the total, were rejected. To reduce the rate of sample rejection, and since the primary purpose of this study was to determine the major faunal changes down core and compare them with the different assemblages present in surface samples, the 
combination of adjacent samples was deemed to be a better solution than the rejection of such a significant portion of freeze core samples.

A first attempt at merging contiguous samples, with the subsequent calculation of pe, resulted in 17 samples being rejected as not statistically significant. Visual inspection of the faunal makeup of these samples revealed that most of them contained low numbers of specimens of well-defined assemblages and that none of them was stratigraphically close to any major faunal shifts. Therefore, it was deemed that a second pass at amalgamating adjacent samples should be carried out to minimize the loss of information due to the discarding of samples. In the end only one group of five samples was not utilized in the statistical analysis (Figure 4).

In these samples, 100 benthic foraminiferal species, four planktic foraminiferal species and ten freshwater thecamoebian species were identified. The relative fractional abundance $\left(\mathrm{F}_{\mathrm{i}}\right)$ of each species was calculated for each sample as follows:

$$
F_{i}=\frac{C_{i}}{N_{i}}
$$

where $C_{i}$ is the species count and $N_{i}$ is the total of all the species count for that sample. Using this information, the standard error $\left(S_{\mathrm{xi}}\right)$ at the $95 \%$ confidence level (Patterson and Fishbein, 1989) associated with each species was calculated using the following formula:

$$
S_{x i}=1.96 \sqrt{\frac{F_{i}\left(1-F_{i}\right)}{N_{i}}}
$$

If the calculated standard error was greater than the fractional abundance for a particular species in all samples then that species was not included in successive 
multivariate analysis. Subsequently, 67 species were rejected from further consideration because they did not have statistically significant numbers in any samples. This number included four planktic foraminiferal species and seven species of thecamoebians. Since all of the planktic foraminifera and thecamoebians were considered allochtonous, it was deemed that their presence or absence might provide some information on transport mechanisms in the area. The different planktic species were therefore grouped together under the generic heading "planktic species", and the ten species of thecamoebians were similarly grouped under "thecamoebian species". A recalculation of fractional abundances and standard errors resulted in 51 species, including the groupings of "planktic species" and "thecamoebian species", being present in statistically significant numbers (Appendix A).

The Shannon-Weaver diversity index (SDI) was used to assess environmental stability based on the proportion and diversity of species found at each sample station within the marshes. This index was calculated using the Shannon and Weaver (1949) formula:

$$
S D I=-\sum_{1}^{S}\left(\frac{F_{i}}{N_{i}}\right) \times \ln \left(\frac{F_{i}}{N_{i}}\right)
$$

where $S$ is equal to the species richness of the sample. The SDI in natural environments normally ranges between 1 and 3.5 , with high values corresponding to stable environments, and low values indicating stressed conditions (Sageman and Bina, 1997). 


\subsubsection{Cluster analysis}

Once the reduced number of statistically significant samples and species were determined, cluster analysis was carried out on the resulting matrix. Cluster analysis is a commonly used multivariate analytical technique in foraminiferal research; it classifies entities (samples or species) into "naturally occurring" groups, and quantifies the relation between groups (Parker and Arnold, 1999). R-mode and Qmode cluster analyses were carried out on the reduced dataset using SPSS 11 for Mac OS X (SPSS, 2005). Q-mode cluster analysis was used to group samples with significantly similar variables (i.e., species), using a proximity matrix with Ward's minimum variance method measured as Square Euclidean Distances (Fishbein and Patterson, 1993). R-mode analysis was carried out using the same methodology to determine which species were most closely related to others, and thus best characterized a particular assemblage.

\subsubsection{Ordination}

Ordination methods represent species distributions related to gradients of environmental change. If data for environmental variables affecting the population are known, a constrained ordination analysis is used, where the variability of the population is represented with respect to the environmental variables measured. If no measured environmental data are accessible, unconstrained analysis will show any variation within the species data along axes that represent gradients of environmental change. The determination of which variables correlate best with the axes is left to the researcher. The results are normally displayed in an ordination diagram that shows the 
axes of the environmental gradients, and the positions of samples and species relative to them.

For this study, a dataset comprised of the surface grab samples and the environmental variables measured for them (depth, temperature, salinity, oxygen content, nitrate + nitrite, silicate and phosphate) was available, although for sample BE3 only the water depth was measured. In order not to lose the valuable information that the species composition of this sample provided, the values for the other variables were imputed by building a multiple regression model, using the samples with no missing values as predictors (Leps and Smilauer, 2003). The procedure was utilized for sample ALS3 as well and its missing values for nitrate + nitrite, silicate and phosphate. The synthetic predictors developed for these two samples were derived from other samples from the same inlet, to minimize dispersion of the data (Table 2).

Ordination analysis commenced with a dataset containing the fractional abundances of statistically significant species for the surface samples, and the environmental variables dataset, using the computer program CANONO 4 (ter Braak and Smilauer, 1998a). The parameter "Depth" was chosen to be interpreted as a covariable, so the ordination diagram showed the relationship between the response variables (species) and environmental variables after eliminating the effect of depth on the sample composition (partial correspondence analysis) (ter Braak and Prentice, 1988).

In order to determine if the response of the species to the environmental variables is unimodal or linear, a preliminary test run was done, selecting Detrended 


\begin{tabular}{ccccccc}
\hline Sample & $\begin{array}{c}\text { Temperature } \\
\left({ }^{\circ} \mathrm{C}\right)\end{array}$ & $\begin{array}{c}\text { Salinity } \\
(p s u)\end{array}$ & $\begin{array}{c}\text { Oxygen } \\
(\mathrm{mL} / \mathrm{L})\end{array}$ & $\begin{array}{c}\text { Nitrate } \\
+ \text { Nitrite } \\
(\mu \mathrm{mol} / \mathrm{L})\end{array}$ & $\begin{array}{c}\text { Silicate } \\
(\mu \mathrm{mol} / \mathrm{L})\end{array}$ & $\begin{array}{c}\text { Phosphate } \\
(\mu \mathrm{mol} / \mathrm{L})\end{array}$ \\
\hline \hline BE1 & 7.84 & 30.05 & 4.95 & 20.9 & 44.0 & 2.20 \\
BE2 & 8.38 & 30.16 & 4.16 & 23.0 & 46.1 & 2.51 \\
BE3 & $8.57^{*}$ & $30.23^{*}$ & $3.70^{*}$ & $22.5^{*}$ & $51.0^{*}$ & $2.43^{*}$ \\
BE5 & 8.61 & 30.23 & 3.71 & 23.0 & 51.8 & 2.45 \\
BE7 & 8.52 & 30.21 & 3.74 & 22.3 & 46.7 & 2.52 \\
ALS1 & 8.55 & 28.83 & 1.67 & 23.3 & 61.9 & 3.23 \\
ALS2 & 8.56 & 28.80 & 1.72 & 23.6 & 61.2 & 3.24 \\
ALS3 & 8.76 & 28.52 & 0.06 & $23.6^{*}$ & $61.2^{*}$ & $3.24 *$ \\
\hline
\end{tabular}

Table 2: values of environmental variables measured at the sediment-water interface samples. The values marked with * represent values imputed with linear regression using the values for the rest of the stations in the same inlet. 
Correspondence Analysis (DCA) on all the response and predictor variables, with depth as a covariable. The gradient length on the first axis showed a value of 4.089 , indicating a large beta diversity in community composition along the individual independent gradients. Use of a linear method would not have been appropriate for the present analysis, since too many species deviate from the assumed model of linear response to the variable (Leps and Smilauer, 2003). The unimodal response method assumes that the species has an optimum on the environmental gradient, with a symmetric bell-shaped response around it. Therefore, the chosen method of analysis was partial Canonical Correspondence Analysis (constrained unimodal ordination with covariables).

A problem arose when the table of Variance Inflation Factors of the environment variables on the DCA log was considered. These factors are related to the (partial) multiple correlation between one environmental variable an the others in the analysis, and all values were extremely high, indicating that the variables were almost perfectly correlated with each other. They therefore do not provide a unique contribution to the regression equation (ter Braak and Smilauer, 1998b). In order to ascertain the influence that the environmental variables have on each other, the correlations between them were calculated with SPSS 11 for Mac OS X (SPSS, 2005), using a two-tailed bivariate correlation with Pearson's coefficient. The result showed that there was a high degree of correlation between several of the variables (Table 3). "Temperature", "oxygen" and "silicate" were the variables subsequently chosen to be retained in the analysis, even though there was a degree of correlation between oxygen and silicate. Partial Canonical Correspondence Analysis was then 


\begin{tabular}{ccccccccc}
\hline \multirow{2}{*}{ DEPTH } & DEPTH & TEMP & SALIN & OXY & NITR & SILICAT & PHOSPH \\
& Pearson Correlation & 1 & -0.18 & $0.889^{* *}$ & $0.741^{*}$ & -0.55 & -0.681 & $-0.844^{* *}$ \\
& Sig. (2-tailed) &. & 0.67 & 0.003 & 0.036 & 0.158 & 0.063 & 0.008 \\
TEMP & N & 8 & 8 & 8 & 8 & 8 & 8 & 8 \\
& Pearson Correlation & -0.18 & 1 & -0.406 & -0.693 & $0.866^{* *}$ & 0.655 & 0.604 \\
& Sig. (2-tailed) & 0.67 & - & 0.318 & 0.057 & 0.005 & 0.078 & 0.113 \\
SALIN & N & 8 & 8 & 8 & 8 & 8 & 8 & 8 \\
& Pearson Correlation & $0.889^{* *}$ & -0.406 & 1 & $0.928^{* *}$ & -0.633 & $-0.908^{* *}$ & $-0.951^{* *}$ \\
& Sig. (2-tailed) & 0.003 & 0.318 & - & 0.001 & 0.092 & 0.002 & 0 \\
OXY & N & 8 & 8 & 8 & 8 & 8 & 8 & 8 \\
& Pearson Correlation & $0.741^{*}$ & -0.693 & $0.928^{* *}$ & 1 & $-0.781^{*}$ & $-0.926^{* *}$ & $-0.942^{* *}$ \\
& Sig. (2-tailed) & 0.036 & 0.057 & 0.001 &. & 0.022 & 0.001 & 0 \\
NITR & N & 8 & 8 & 8 & 8 & 8 & 8 & 8 \\
& Pearson Correlation & -0.55 & $0.866^{* *}$ & -0.633 & $-0.781^{*}$ & 1 & $0.793^{*}$ & $0.805^{*}$ \\
& Sig. (2-tailed) & 0.158 & 0.005 & 0.092 & 0.022 &. & 0.019 & 0.016 \\
SILICAT & N & 8 & 8 & 8 & 8 & 8 & 8 & 8 \\
& Pearson Correlation & -0.681 & 0.655 & $-0.908^{* *}$ & $-0.926^{* *}$ & $0.793^{*}$ & 1 & 0.947 \\
& Sig. (2-tailed) & 0.063 & 0.078 & 0.002 & 0.001 & 0.019 &. & 0 \\
PHOSPH & N & 8 & 8 & 8 & 8 & 8 & 8 & 8 \\
& Pearson Correlation & $-0.844^{* *}$ & 0.604 & $-0.951^{* *}$ & $-0.942^{* *}$ & $0.805^{*}$ & $0.947^{* *}$ & 1 \\
& Sig. (2-tailed) & 0.008 & 0.113 & 0 & 0 & 0.016 & 0 &. \\
& N & 8 & 8 & 8 & 8 & 8 & 8 & 8 \\
\hline
\end{tabular}

Table 3: values for the Pearson correlation coefficient for the environmental variables. **: Correlation is significant at the 0.01 level (2-tailed).*: Correlation is significant at the 0.05 level (2-tailed).

applied to the dataset composed of fractional abundances of statistically significant species from the surface samples, and the environmental variables "temperature", "oxygen" and "silicate", with "depth" as a covariable.

\subsubsection{Transfer function}

Recent developments in quantitative paleoenvironmental reconstruction employing transfer functions have permitted the reconstruction of past values for a suite of environmental variables. The development of transfer functions has generally 
focused on diatoms and their utility as indicators of hydrochemical characteristics

(e.g. Birks et al., 1990; Campeau et al., 1999; Gasse et al., 1995), though they have been applied as well with foraminifera to determine past sea levels (e.g., Edwards and Horton, 2000; Gehrels, 2000; Patterson et al., 2004a).

The use of microfossils in paleoenvironmental reconstruction is based on the assumption that the modern relation between indicator species and environmental variables of interest has not changed through time. In this way, by quantifying the present distribution of indicators (foraminifera in this case) with respect to the target variables, their distribution in paleoenvironments can be used as a proxy for former environmental conditions, given that the fossil assemblages have analogues in the surface fauna.

This is a two-step process. First, the response of modern foraminifera with respect to environmental variables is modeled with regression analysis. The resultant coupled assemblage-variable data constitutes a training set. Secondly, the modeled responses are used to infer past conditions from the composition of fossil foraminifera assemblages through calibration. The set of mathematical equations that achieve this calibration is the transfer function.

To estimate the error of the transfer function, cross-validation is performed on the datasets. However, due to the very small size of the training set used on this study (only eight samples), the software was not able to perform the validation; therefore, the reconstructions of past environmental data values are shown here without error estimates. 
In this study, transfer functions were derived using the computer program C2 (Juggins, 2005). The program calculates the transfer function using two methods: weighted averaging (WA) and weighted averaging with tolerance downweighting (WA (Tol)). Both techniques are suitable for species that display an unimodal response to the environmental variables in question (Birks et al., 1990), as shown by the CCA results to be the case in the present study. WA (Tol) is a modification of WA where species with narrow ranges are given more weight, because they have a better indicator value.

The statistical parameters produced by $\mathrm{C} 2$ are the apparent root mean square error (RMSE), a coefficient of determination $\left(\mathrm{r}^{2}\right)$, and values for average and maximum bias. The RMSE is a measure of the predictive accuracy of the model (Wallach and Goffinet, 1989), which is the average square difference between observed values and values predicted by the model. The maximum bias is the largest difference between mean observed and predicted values along the environmental gradient in question. Both WA and WA(Tol) analyses were performed on the data set, with classical and inverse deshrinking. Deshrinking is necessary in WA reconstructions because the averages are taken twice, once in regression and once in calibration, which results in shrinkage of the range of inferred environmental values (Birks et al., 1990).

The modern data set is the same one used in the ordination analysis, and the dataset used to calibrate the function comprises the fractional abundances of statistically significant species found in core $\mathrm{FCO4}$, as shown in the cluster analysis methodology. 


\section{Results}

\subsection{Chronology}

The ${ }^{210} \mathrm{~Pb}$ dates were calculated using the constant rate of supply (CRS) method, which assumes that the rate of supply of ${ }^{210} \mathrm{~Pb}$ to the sediments is constant, regardless of changes in the sedimentation rate (Table 4). The calculated value for the sedimentation rate with this method was $1.52 \mathrm{~mm} / \mathrm{yr}$.

The radiocarbon dates obtained were the average of two separate analyses, and were corrected for ${ }^{13} \mathrm{C} /{ }^{12} \mathrm{C}$ isotope fractionation. They were calibrated using the radiocarbon calibration program CALIB, version 5.0.1 for Mac OS X, with the Intcal.04 calibration data set (Reimer et al., 2004). CALIB makes the conversion from radiocarbon age to calibrated calendar years by calculating the probability distribution of the samples' true age (Stuiver et al., 2005). The dates are reported as calendar years $\mathrm{AD}$ (cal yr AD), and as the median probability of the $95.5 \%(2 \sigma)$ confidence interval (Table 5). No marine reservoir effect was applied to the bulk sediment

\begin{tabular}{cccccc}
\hline Sample & $\begin{array}{c}\text { Depth } \\
(\mathrm{cm})\end{array}$ & $\begin{array}{c}{ }^{\mathbf{2 1 0}} \mathbf{P b} \\
(\mathrm{B} q / \mathrm{g})\end{array}$ & $\begin{array}{c}\text { Precision } \\
\mathbf{1} \text { std } \\
(\%)\end{array}$ & $\begin{array}{c}\text { Age } \\
(\text { year } A D)\end{array}$ & $\begin{array}{c}\text { STD in date } \\
(\text { years })\end{array}$ \\
\hline \hline FC04-1 & 1 & 0.204 & 4.9 & 2002 & 0.0 \\
FC04-2 & 2 & & & 2001 & \\
FC04-3 & 3 & 0.127 & 5.0 & 2000 & 0.7 \\
FC04-4 & 4 & & & 1999 & \\
FC04-5 & 5 & 0.214 & 5.6 & 1995 & 1.3 \\
FC04-6 & 6 & & & 1990 & \\
FC04-7 & 7 & 0.145 & 6.2 & 1979 & 6.5
\end{tabular}




\begin{tabular}{lccccc} 
FC04-8 & 8 & & & 1972 & \\
FC04-9 & 9 & 0.125 & 3.8 & 1964 & 12.3 \\
FC04-10 & 10 & & & 1956 & \\
FC04-11 & 11 & 0.083 & 3.9 & 1943 & 37.0 \\
FC04-12 & 12 & & 1932 & \\
FC04-16 & 16 & 0.078 & 5.7 & 1897 & 76.2 \\
FC04-20 & 20 & 0.045 & 5.4 & & \\
FC04-23 & 23 & 0.051 & 8.9 & & \\
FC04-28 & 28 & 0.039 & 8.9 & & \\
FC04-31 & 31 & 0.051 & 7.5 & & \\
FC04-35 & 35 & 0.076 & 6.9 & & \\
FC04-40 & 40 & 0.033 & 5.7 & \\
FC04-42 & 42 & 0.018 & 8.0 & \\
FC04-81 & 81 & 0.027 & 9.0 & \\
\hline
\end{tabular}

Table 4: results of the ${ }^{210} \mathrm{~Pb}$ analysis, showing the ages at different depths on the top section of FC04, and their standard deviation. The sedimentation rate calculated from these dates is $1.52 \mathrm{~mm} / \mathrm{yr}$.

sample derived date, since there are no studies in the variations of reservoir effects in enclosed fjords such as the SBIC. Even though areas of strong upwelling such as the east coast of Vancouver Island tend to have strong marine reservoir effects (up to 1200 years, Hutchinson et al., 2004), values for estuaries are very much affected by the freshwater inflow, especially at boundaries between different ocean circulation regimes, such as the SBIC (Ingram and Southon, 1996). 
An age-depth model based on calibrated radiocarbon dates was constructed using linear interpolation, since this method has been demonstrated to provide the best performance when the number of dates is low (Telford et al., 2004). A depth of 0 $\mathrm{cm}$ was included in the linear regression as the year $\mathrm{AD} 2002$, a value corroborated by the ${ }^{210} \mathrm{~Pb}$ dating. The fact that the first radiocarbon date (FC04-89) was chosen from a depth where there is a change in sediment lithology strengthens the validity of the model (Telford et al., 2004). The sedimentation rate was calculated from the slope of the regression curve, giving a result of $1.24 \mathrm{~mm} / \mathrm{yr}$, in close agreement with the ${ }^{210} \mathrm{~Pb}$ data (Figure 5). 


\begin{tabular}{|c|c|c|c|c|c|c|c|}
\hline $\begin{array}{c}\text { Sample } \\
\text { name }\end{array}$ & $\begin{array}{c}\text { Lab } \\
\text { number }\end{array}$ & $\begin{array}{l}\text { Depth } \\
(\mathrm{cm})\end{array}$ & Sample type & $\begin{array}{c}\text { Radiocarbon } \\
\text { age } \\
(y r B P)\end{array}$ & $\begin{array}{c}\text { Calibrated Calendar } \\
\text { Date } \\
\text { (cal yr } A D)\end{array}$ & $\begin{array}{c}\text { Median } \\
\text { Probability } \\
\text { Date } \\
(y r A D)\end{array}$ & $\begin{array}{c}\text { error } \\
\text { 2sigma } \\
(y r)\end{array}$ \\
\hline FC04-89 & TO- 12566 & 89 & Wood & $530 \pm 40$ & $1387-1444$ & 1415 & 28 \\
\hline FC04-128 & TO-12567 & 128 & Sediment & $1060 \pm 50$ & $875-1046$ & 960 & 85 \\
\hline
\end{tabular}

Table 5: radiocarbon ages and calibrated ages (years AD) for the two radiocarbon samples sent to Isotrace Lab. The calibration was done using the program CALIB v. 5.0.1., with the calibration dataset Intcal.04. The calibrated results are reported at the $95.5 \%(2 \sigma)$ confidence interval. The median probability ages are rounded to the nearest year. 


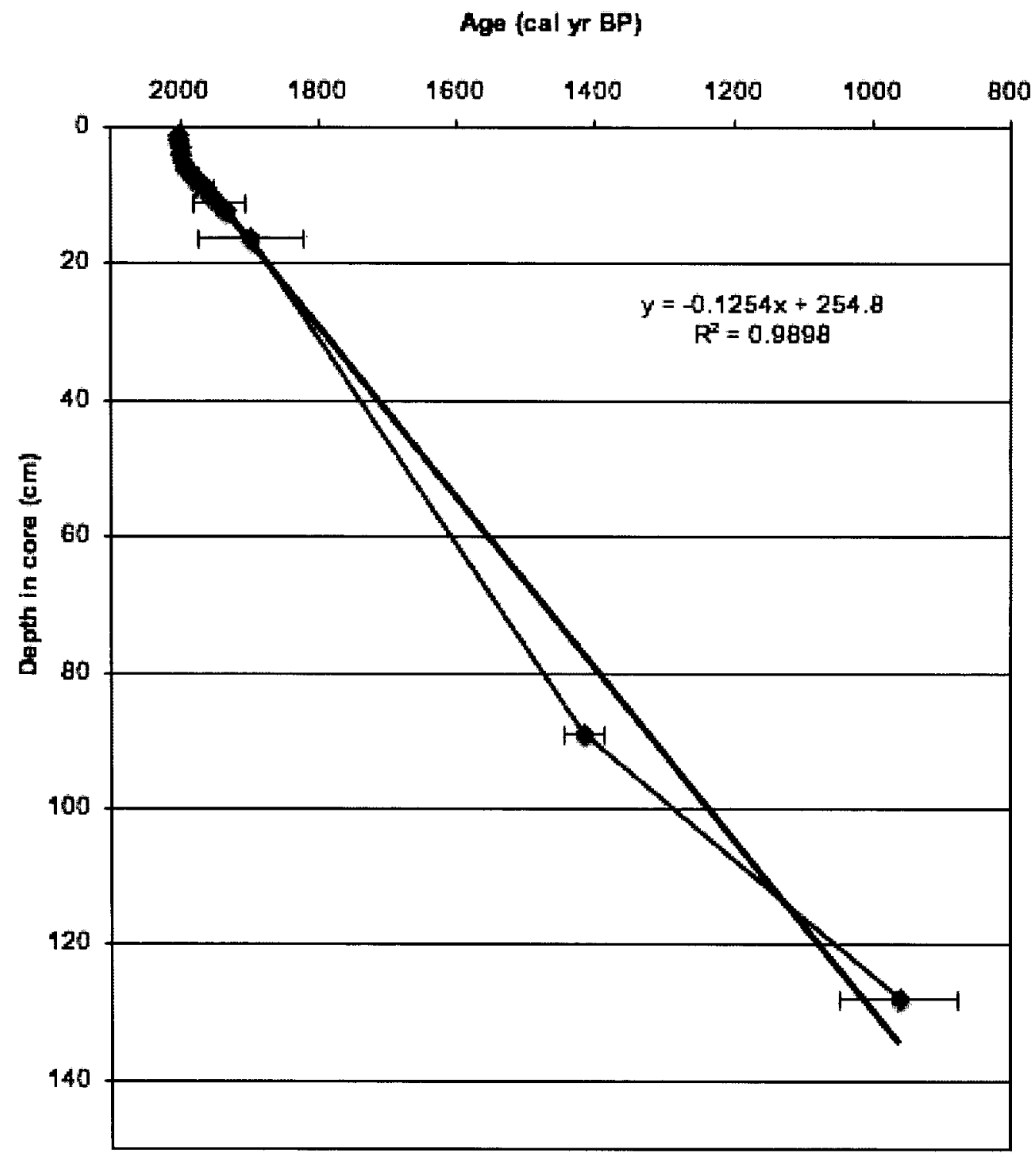

Figure 5: age-depth model for calibrated radiocarbon dates. The sediment accumulation rate derived from the slope of the linear regression line is $1.242 \mathrm{~mm} / \mathrm{yr}$. Horizontal error bars represent the range of ages defined by the probability distribution of the samples' true age. 


\subsection{Environmental variables}

The data for different environmental variables were kindly provided by Dr. R.E. Thomson and C. Wright from the Institute of Ocean Sciences (Sydney, BC), and they were plotted for both Belize Inlet (Figure 2) and Alison Sound (Figure 3) using Ocean Data View, version 3.0.4 for Mac OS X (Schlitzer, 2004).

The profiles for Belize Inlet (Figure 2) show a marked wedge of ocean water entering the inlet, with temperature values lower than $8^{\circ} \mathrm{C}$ and a high oxygen content (more than $5 \mathrm{~mL} / \mathrm{L}$ ). Towards the head of the inlet, an oxygen minimum zone at middepth can be observed, with the lowest values of the profile $(1 \mathrm{~mL} / \mathrm{L})$. This minimum appears to be an intermittent feature in low runoff fjords of the coast of British Columbia. It was first supposed that high oxygen demand in the surface water depleted the oxygen in the lower water column, but a steady flow of dense oxygenated water sinks to the bottom and replenishes the values there (Pickard and Stanton, 1980). Recent surveys indicate that the oxygen minimum zone may be the result of water leaking from a salt water marsh at the head of Belize Inlet and settling in at that density layer (Cindy W. Right, written communication, 2006). Oxygen values in the deeper portions of the inlet do not fall below $\sim 3 \mathrm{~mL} / \mathrm{L}$.

The salinity profile displays a low-salinity wedge in the surface water (less than $30 \mathrm{~m}$ deep), strengthened towards the head of the inlet. Salinity at depth remains fairly constant, with average values of $30 \%$. This profile is consistent with the input of freshwater from rivers and creeks up the fjord.

In Alison Sound (Figure 3), temperature values were relatively constant. Only towards station ALS3 was an increase from $8.5^{\circ} \mathrm{C}$ to $9^{\circ} \mathrm{C}$ observed, probably 
reflecting the shallower depth of the inlet. Oxygen concentration, however, is lower when compared with Belize Sound, undergoing a sharp gradient from surface to bottom waters. Minimum values close to $0 \mathrm{~mL} / \mathrm{L}$ appear at depth at the head of the inlet, whereas input of oxygenated water $(>3 \mathrm{~mL} / \mathrm{L})$ coming from Belize Inlet is manifest at stations ALS1 and ALS2. The low salinity wedge is also present in Alison Sound, although the overall salinity values are lower than those in Belize Inlet, with a maximum of $29 \%$.

\subsection{Cluster analysis}

The results of cluster analysis show a clear partition of the samples into four different assemblages, some of which are represented in both core and surface samples (Figure 6). The stratigraphic order of the assemblages is represented in Figure 4. The value of the SDI for all the assemblages remained between 1.41 and 1.84 , indicating a moderately stable environment.

\subsubsection{Assemblage 1}

The first assemblage defined comprises 19 samples and includes samples FC04-77 to FC04-138 in the core (the basal portion) as well as samples ALS1 and ALS3. It is dominated by Eggerella advena (Cushman, 1922), with an average occurrence of $29.7 \%$ (range $15.7 \%-47.15 \%$ ), and Eggerella belizensis n. sp., with an average of $24.3 \%$ (range $0.0 \%$ - 34.78\%). Another important species is Cribrostomoides cf. subglobosum (Cushman, 1910a) (average 9.0\%, range 0.0\% $23.9 \%$ ), with more than $15 \%$ of the total assemblage in five samples. Recurvoides turbinatus (Brady, 1881) is present in 17 of the 19 samples, ranging between $5.7 \%$ 
and $23.3 \%$ (average of 11.0\%). Spiroplectammina biformis (Parker and Jones, 1865 ) is significantly represented as well, comprising a total of $7.1 \%$ of the population on average (range between $0.0 \%-22.4 \%$ ). Other important species are Cribrostomoides jeffreysii (Williamson, 1858) (average of $1.0 \%$, range $0.0 \%-11.0 \%$ ) and Ammodiscus gullmarensis Höglund (1948) (average of 1.5\%, range $0.0 \%-8.1 \%$ ).

Thecamoebians are present in $50 \%$ of the samples, with an average abundance of $5.7 \%$, and ranging between $1.0 \%$ and $26.5 \%$. Planktic foraminiferal species appear in a lone sample, making up $1.9 \%$ of the counts in that sample $(0.1 \%$ of the total assemblage).

Other agglutinated foraminiferal species present in lone samples are Portatrochammina bipolaris (Brönnimann and Whittaker, 1980), Cribrostomoides crassimargo (Norman, 1892), Miliammina fusca (Brady and Robertson, 1870), Cribrostomoides sp. A, Trochammina globigeriniformis (Parker and Jones, 1865), Trochammina nana (Brady, 1881), and the calcareous species Stainforthia feylingi Knudsen and Seidenkrantz, 1994.

All the samples in this assemblage are dominated by agglutinated foraminiferal species, with the exception of sample FC04-77, that presents a few planktonic specimens, and sample FC04-138, where $S$. feylingi appears, contributing to $4.8 \%$ of that sample. The SDI has a value of 1.49 .

\subsubsection{Assemblage 2}

This assemblage is comprised of 29 samples collected from FC04, at $11 \mathrm{~cm}$ to $64 \mathrm{~cm}$ core depth. The most representative species in this group is Buccella frigida 
(Cushman, 1922), which appears in every sample, with an average concentration of 27.3\% (range 52.3\%-6.3\%). The second most abundant species is Cribroelphidium excavatum (Terquem, 1876) forma 'magna' (Miller et al., 1982), which comprises $21.6 \%$ of the population, ranging between $44.1 \%$ and $6.7 \%$. Cribroelphidium excavatum forma 'clavata' (Cushman, 1930) follows closely, with an average abundance of $15.0 \%$ (range $0.0 \%$ - 27.9\%). Nonionellina labradorica (Dawson, 1860) is significantly represented as well, forming $9.5 \%$ of the population on average, reaching up to $36.8 \%$ in some depths.

Another abundant species is Cribroelphidium foraminosum (Cushman, 1939), which ranges between $0.0 \%$ and $11.6 \%$ (average of $3.0 \%$ ). Cribroelphidium excavatum forma 'excavata' (Terquem, 1876), also a member of the C. excavatum family, is present in eight of the samples of this assemblage; its total average is $1.9 \%$ (range $0.0 \%-9.2 \%$ ). Cassidulina crassa d'Orbigny, 1939 is an important indicator species in this assemblage, with an average of $2.0 \%$, reaching a maximum of $16.2 \%$. Buccella tenerrima (Bandy, 1950) represents $1.2 \%$ of the assemblage (range $0.0 \%$ $7.4 \%)$

A proportion of $0.8 \%$ of the assemblage is made up of Epistominella vitrea Parker, 1953 (range $0.0 \%-6.3 \%$ ). Other species that represent less than $1 \%$ of the population in this assemblage include Lobatula fletcheri (Galloway and Wissler, 1927) (average $0.5 \%$; range $0.0 \%-3.7 \%$ ), Cribroelphidium excavatum forma 'selseyensis' (Heron-Allen and Earland, 1911) (average 0.4\%; range 0.0\%-9.1\%), Neouvigerina cf. proboscidea (Schwager, 1866) (average $0.4 \%$; range $0.0 \%-7.4 \%$ ), Lobatula mckannai (Galloway and Wissler, 1927) (average 0.3\%; range 0.0\% - 
8.5\%), Bolivina minuta Natland, 1938 (average 0.3\%; range 0.0\% - 6.3\%), Euuvigerina peregrina (Cushman, 1923) (average 0.2\%; range 0.0\% - 2.4\%), undifferentiated variants of C. excavatum (average $0.1 \%$; range $0.0 \%-4.0 \%$ ), Buccella inusitata Andersen, 1952 (average 0.1\%; range 0.0\% - 3.0\%), Elphidiella hannai Cushman and Grant, 1927 (average 0.1\%; range 0.0\%-4.4\%), and S. feylingi (average $0.1 \%$; range $0.0 \%-2.6 \%$ ).

All the species of this assemblage are calcareous benthic foraminifera.

\subsubsection{Assemblage 3}

This assemblage comprises only five samples from $\mathrm{FC} 04$, at core depths 65 to $68 \mathrm{~cm}$ (both inclusive) and $76 \mathrm{~cm}$. It is a mixed assemblage, where agglutinated foraminifera make up on average $13 \%$ of the population.

The distinctiveness of the assemblage lies with the very high numbers of $S$. feylingi, which incorporates almost half of the population on average (49.3\%; range $40.6 \%-57.0 \%$ ). The following most abundant species is Haplophragmoides bradyi (Brady, 1887), with an average of $10.4 \%$ (range $8.2 \%-15.7 \%$ ). C. excavatum 'clavata' represents $9.9 \%$ of the assemblage, with values between 4.3 and $14.3 \%$ in different samples. Other members of the $C$. excavatum family, such as $C$. excavatum 'magna' (average 2.6\%; range $0.0 \%-4.6 \%$ ) and C. excavatum 'excavatum' (average $2.2 \%$; range $0.0 \%-5.5 \%$ ), make up almost $5 \%$ of the population when factored together. B. frigida represents a close $4.9 \%$ (range $1.2 \%-7.2 \%$ ), while C. crassa follows closely with an average of $4.7 \%$ (range $2.1 \%-6.8 \%$ ). N. labradorica accounts for $3.2 \%$ of the population (range $0.0 \%-5.6 \%$ ). Both E. vitrea and $B$. 


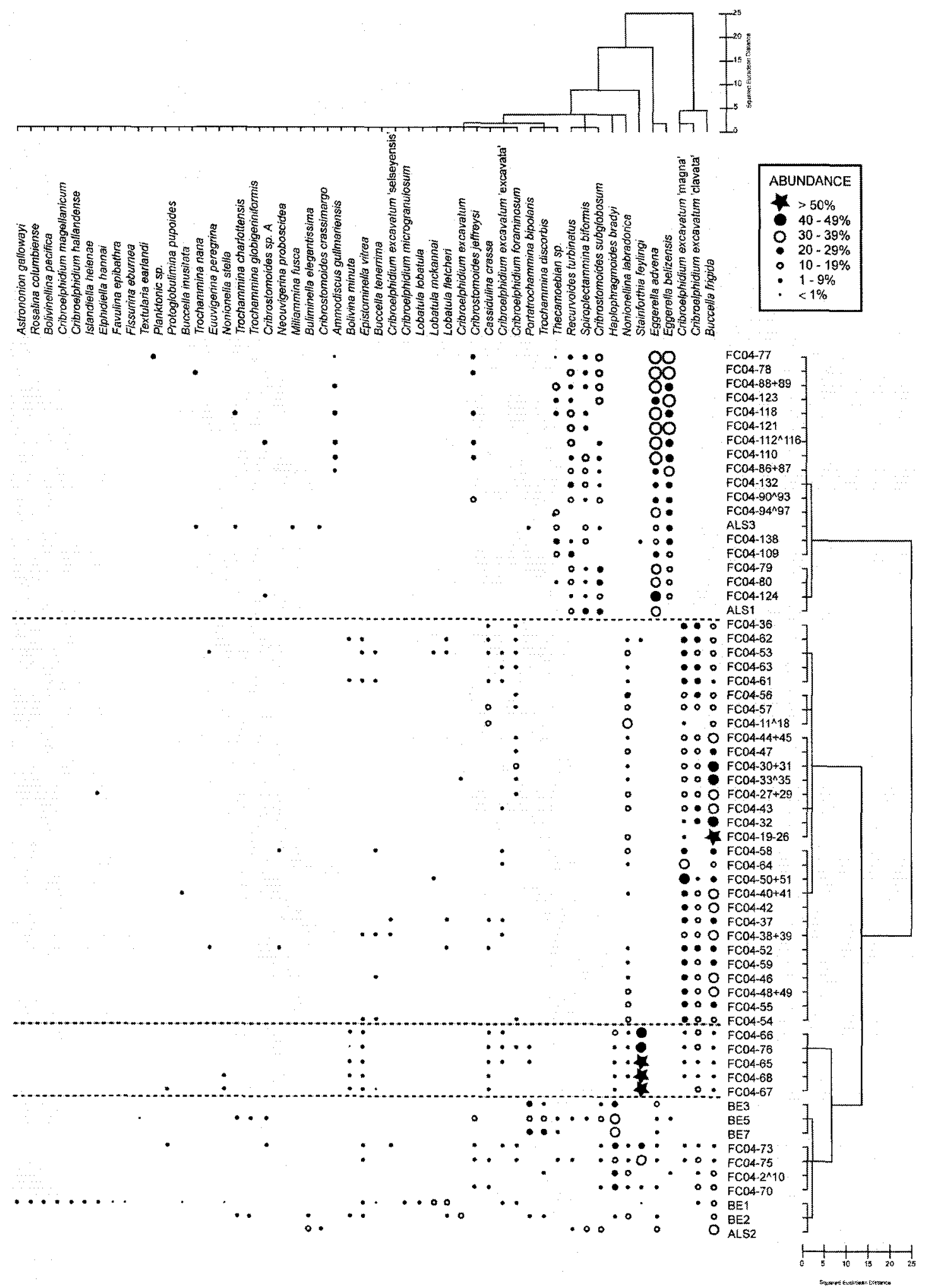

Figure 6: Q-mode vs. R-mode cluster diagram for FCO4 and surface samples, with fractional abundances of the species indicated by symbols. 
minuta are present in all the samples of this assemblage, with averages of $2.2 \%$ and $1.6 \%$ respectively (ranges of $1.5 \%-2.7 \%$ and $1.0 \%-2.0 \%$ ). More scarcely abundant species are Nonionella stella (Cushman and Moyer, 1930) (average 1.4\%; range 0.0\% - 5.8\%), C. foraminosum (average 0.9\%; range 0.0\%-4.7\%), P. bipolaris (average $0.5 \%$; range $0.0 \%-1.2 \%$ ), Protoglobulimina pupoides (d'Orbigny, 1846) (average $0.3 \%$; range $0.0 \%-1.3 \%$ ) and $B$. tenerrima (average $0.2 \%$; range $0.0 \%-0.9 \%$ ).

\subsubsection{Assemblage 4}

Assemblage 4 groups together surface samples from Belize Inlet, as well as sample ALS2, and from FC04, the 2 to $10 \mathrm{~cm}$, and 70 to $75 \mathrm{~cm}$ intervals.

This assemblage has the most diverse fauna of all assemblages (SDI $=1.84$ ), with $H$. bradyi and $B$. frigida being the dominant species (average $18.8 \%$; range $0.0 \%$ $-37.6 \%$, and average $10.5 \%$; range $0.0 \%-33.2 \%$ respectively).

Other important contributors to the fauna of this assemblage are $S$. feylingi (average $6.4 \%$; range $0.0-32.2 \%$ ) and $E$. advena (average $5.6 \%$; range $0.0-15.0 \%$ ). P. bipolaris and Trochammina discorbis Earland, 1934 reach similar numbers, both with averages of $5.5 \%$ each (ranges of $0.0-20.5 \%$ and $0.0-23.9 \%$ respectively). $N$. labradorica has an average abundance of $4.1 \%$, ranging between 0.0 and $17.5 \%$. Four percent of the assemblage is made of $C$. cf. subglobosum individuals (range $0.0-$ $14.2 \%$ ), and $3.7 \%$ of C. excavatum 'clavata' (range $0.0-11.8 \%$ ). The only other species that surpasses $2 \%$ of the total population is C. jeffreysii (average 2.3\%; range $0.0-14.2 \%$ ); L. fletcheri is on the borderline (average $2.0 \%$; range $0.0-10.6 \%$ ). Five species range between $1 \%$ and $2 \%$ of the total counts: $C$. excavatum $(1.8 \%), R$. 
turbinatus (1.4\%), Buliminella elegantissima (d'Orbigny, 1839) (1.4\%), L. mckannai (1.2\%) and S. biformis (1.2\%). Thecamoebians form $1.2 \%$ of this assemblage (range $0.0-8.5 \%$ ).

There are 28 other species with average values of less than $1 \%$ of the total population (see Appendix A).

The percentage of agglutinated foraminifera averages $58 \%$ in this assemblage; it varies, however, between samples with $100 \%$ of agglutinated species to samples with $100 \%$ of calcareous foraminifera.

\subsection{Ordination}

The chosen axes of environmental variability explain $74.4 \%$ of the total variance in the species data (total inertia, 2.294, Table 6). The first axis is the most important one, explaining $41 \%$ of the variance, with an eigenvalue of 0.741 . This axis is very well correlated with the environmental data $(r=0.978)$. The second axis, characterized by a smaller eigenvalue (0.36), explains an additional $19.9 \%$ of the variance, and is also strongly correlated $(\mathrm{r}=0.947)$. These correlations suggest that the data set is governed by these two dominant gradients (Leps and Smilauer, 2003). The difference between the total variation explained by the axis and the total inertia of the dataset $(2.294-1.807)$ is explained by the covariables of the analysis, in this case depth, whose effect is removed from the other variables.

The percentage variance explained by the axes of the ordination analysis are very close to those explained by the axes of the unconstrained DCA (e.g., 41 in comparison with 43.3 ); the species-environment correlation is only slightly higher. 


\begin{tabular}{|c|c|c|c|c|c|}
\hline Axes & 1 & 2 & 3 & 4 & $\begin{array}{c}\text { Total } \\
\text { inertia }\end{array}$ \\
\hline Eigenvalues & 0.741 & 0.36 & 0.244 & 0.21 & 2.294 \\
\hline Species-environment correlations : & 0.978 & 0.947 & 0.98 & 0 & \\
\hline \multicolumn{6}{|l|}{ Cumulative percentage variance } \\
\hline of species data & 41 & 60.9 & 74.4 & 86 & \\
\hline of species-environment relation: & 55.1 & 81.8 & 100 & 0 & \\
\hline Sum of all unconstrained eigenvalues & & & & & 1.807 \\
\hline Sum of all canonical eigenvalues & & & & & 1.344 \\
\hline
\end{tabular}

Table 6: values for the Canonical Correspondence Analysis (CCA) of the surface samples 
This suggests that the measured environmental variables are the ones responsible for the variation in species composition.

The position of the environmental variable vectors in relation to the axes summarizes the relative weight of each variable in determining each axis (Figure 7). From the triplot, it can be observed that temperature is highly negatively correlated with the first axis, whereas oxygen and silicate are both correlated with axis 1 and axis 2 , oxygen positively and silicate negatively. Hence, the diagram can be divided in two ways. In the first one, the left side of the diagram shows an affinity for higher temperatures, but when values move towards the right side, the optimum temperature values for the species diminish. With regards to oxygen and silicate, the upper right quadrant is populated with species with an affinity to high oxygen concentrations and low silicate values; the opposite is true for the lower left quadrant. If the vectors of the environmental variables are extended, and perpendicular lines linking them with the species scores drawn, it is possible to infer a qualitative position of the optimum for that species regarding that particular variable. The fact that there are several species occupying the same point on the triplot (Ihellen, Cexex, Cmicrogr, Lmckan, Llobat) indicates that their relative abundances are judged identical by the method in different samples.

The relative position of samples and species indicates the tendency of some of the species to occur in certain samples. From the figure, it can be seen that the agglutinated foraminifera and thecamoebians occur in settings of higher temperature relative to the mean (samples from Alison Sound and BE3, BE5 and BE7). Most of the calcareous foraminifera appear to prefer colder temperatures. As well, species 


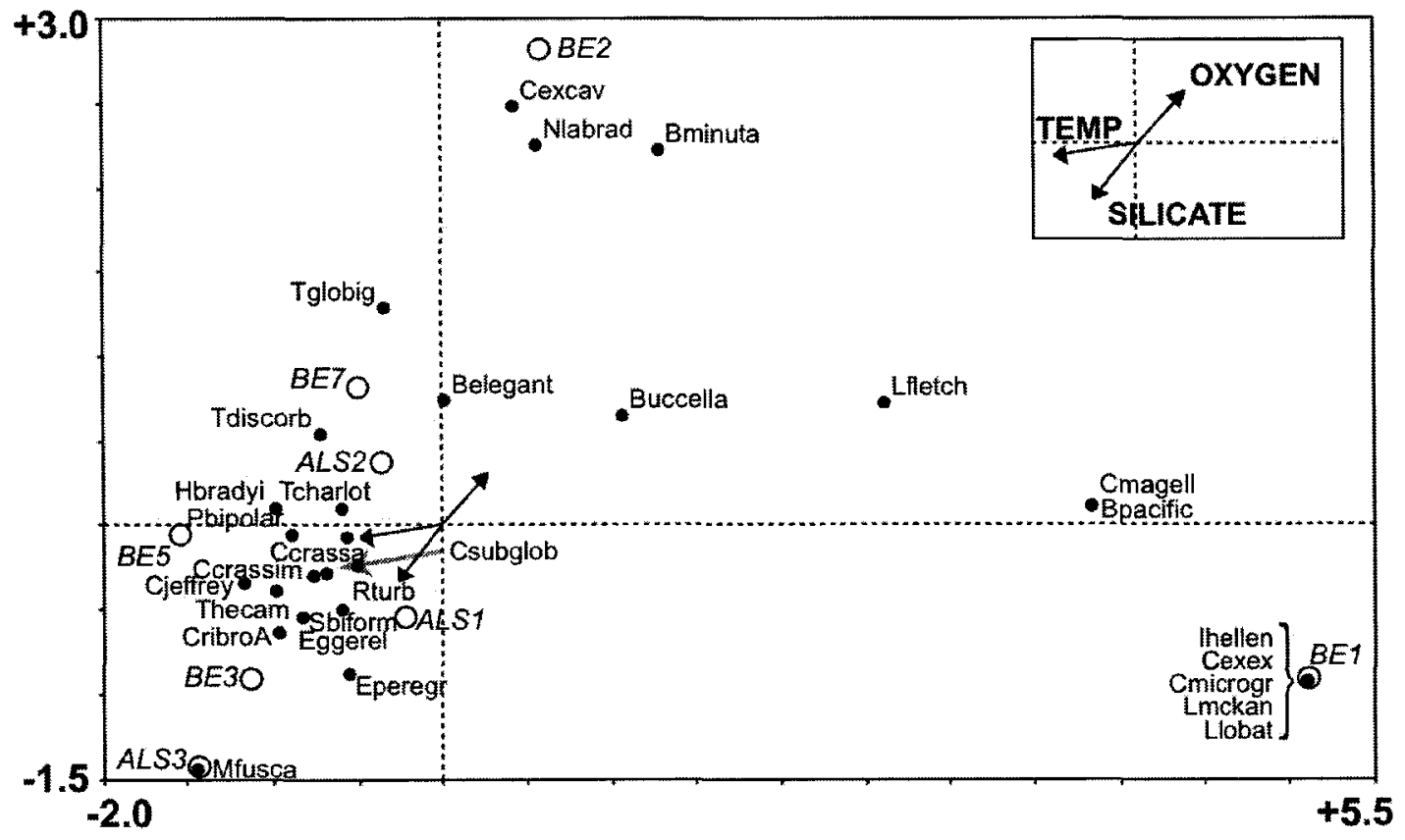

Figure 7: CCA triplot, representing the relation between the faunal distribution in the SBIC and temperature, oxygen and silicate. Filled circles represent species; open circles represent samples. 
such as E. advena, C. crassimargo, C. subglobosum, S. biformis, M. fusca, E. peregrina and thecamoebians are abundant in low-oxygen high-silicate environments; the opposite is true for Buccella sp., $N$. labradorica, members of the Cribroelphidium and Lobatula groups and B. elegantissima, that thrive in relatively higher oxygen settings.

\subsection{Transfer function}

WA regression was used to describe the response of species (optima and range) as a function, first of oxygen and secondly of temperature.

Table 7 shows the values of RMSE, $\mathrm{r}^{2}$ and maximum bias for both functions using the four different models described above. Inversion deshrinking gives better results for both the RMSE and $\mathrm{r}^{2}$ for the two models. With respect to the model type, however, WA with tolerance downweighting performs better for oxygen, while temperature is best represented by WA.

The reconstructions for oxygen and temperature in core FC04 are shown in Figure 8, along with the stratigraphic values of key foraminiferal species. They can be correlated with the groups of samples as estimated by cluster analysis.

From the bottom of the core (depth of $138 \mathrm{~cm}$ ) to a depth of $77 \mathrm{~cm}$, the oxygen concentration seems to have been much lower than today, with a fairly constant average of $\sim 1.0 \mathrm{~mL} / \mathrm{L}$. The predicted values for water temperature, on the other hand, are slightly higher $\left(8.6^{\circ}\right)$ than at present. This zonation corresponds with a complete dominance of agglutinated foraminifera, such as $C$. cf. subglobosum, Eggerella sp., R. turbinatus and S. biformis (Assemblage 1). Thecamoebians are very 


\begin{tabular}{lccc}
\hline Oxygen & & & \\
\hline & RMSE & $\mathrm{r}^{2}$ & Max. bias \\
\hline WA (Inv) & 0.4225 & 0.9239 & 0.7529 \\
WA (Cla) & 0.4396 & 0.9239 & 0.7769 \\
WATOL (Inv) & 0.2553 & 0.9722 & 0.5120 \\
WATOL (Cla) & 0.2589 & 0.9722 & 0.4436 \\
\hline & & & \\
\hline Temperature & & & \\
\hline & RMSE & $\mathrm{r}^{2}$ & Max. bias \\
\hline \hline WA (Inv) & 0.0532 & 0.9578 & 0.0842 \\
WA (Cla) & 0.0544 & 0.9578 & 0.0753 \\
WATOL (Inv) & 0.0663 & 0.9346 & 0.1360 \\
WATOL (Cla) & 0.0685 & 0.9346 & 0.1255 \\
\hline
\end{tabular}

Table 7: performance of the two regression models, WA and WA(Tol), with classical (Cla) and inversion (Inv) deshrinking, for the oxygen and temperature reconstructions of the foraminiferal fossil set of $\mathrm{FC} 04$. Values in $\mathrm{mL} / \mathrm{L}$ and ${ }^{\circ} \mathrm{C}$, respectively. 
abundant, and a marginal occurrence of $S$. feylingi can be observed at the base of the core.

At a depth of $77 \mathrm{~cm}$, a drastic change takes place. Oxygen concentration values increase significantly to $\sim 4 \mathrm{~mL} / \mathrm{L}$, while temperatures drop around $0.6^{\circ}$. This depth corresponds to Assemblage 3. High abundances of S. feylingi are observed, and calcareous species begin to appear.

At cm. 74, the species' proportions change to those of Assemblage 4 and abundances of $S$. feylingi, although still high, become reduced with respect to Assemblage 3, and $H$. bradyi plays a dominant role. A smaller increase in temperature is noticeable, though oxygen values do not change significantly. The lack of change in temperature and oxygen concentration values with regard to the previous one is probably a reflection of the absence of surface analogues for Assemblage 3 (Figure 5). Stainforthia feylingi, the dominant species, does not appear as profusely anywhere in the surface samples. The closest assemblage is that of cluster 4 , which includes smaller abundances of $S$. feylingi, so the values of temperature and oxygen for zone D mirror those of zone C (Figure 8).

The faunal composition changes again to Assemblage 3 at $68 \mathrm{~cm}$ : temperatures decrease, and oxygen seems to undergo a slight increase.

At $\mathrm{cm}$. 64, oxygen values rise to almost $5 \mathrm{~mL} / \mathrm{L}$. Temperatures remain around $8.1^{\circ}$, though the trend seems to be quite noisy. The fauna changes completely to that of Assemblage 2, with complete dominance of calcareous species. 

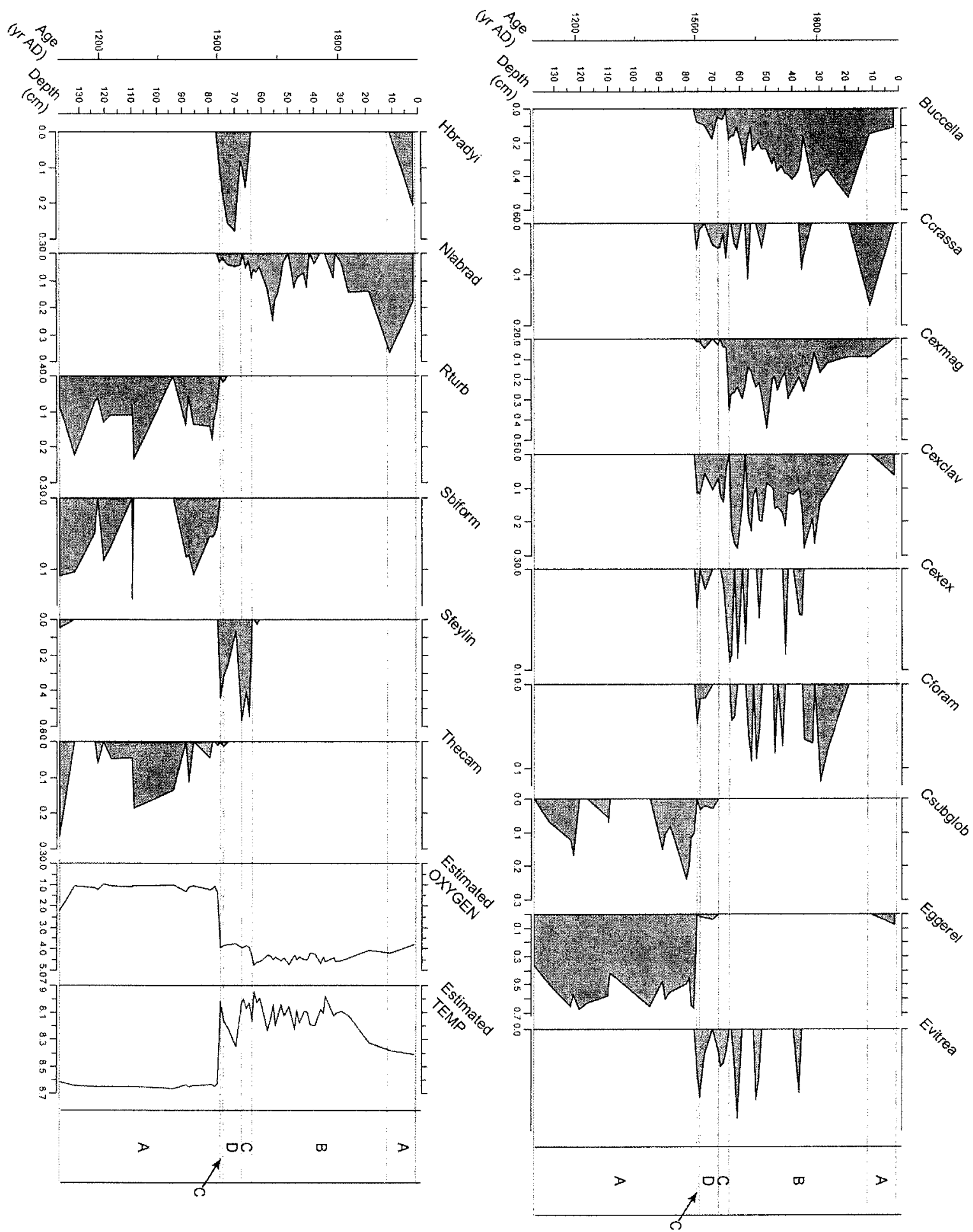
At $11 \mathrm{~cm}$, both temperature and oxygen values tend towards those of zone A. In fact, the dominant species in the top of the core are the same as those in the bottom (Assemblage 1)

\section{Discussion}

\subsection{Modern Distribution of Foraminifera in the SBIC}

The distribution of foraminiferal assemblages in both Belize Inlet and Alison Sound follow a common trend in many other higher latitude estuarine environments. In these environments, low diversity agglutinated faunas typically dominate deepwater, brackish areas where dysoxic conditions often prevail, and a higher diversity calcareous fauna is more common in areas where there is more open marine influence (Sen Gupta, 1999).

All foraminiferal assemblages found in the modern sediment-water interface samples from Belize Inlet correspond to Assemblage 4, the most faunally diverse assemblage observed in this study. This result is not unexpected, as salinity $(30 \%$ ) and oxygen concentrations $(\sim 3 \mathrm{~mL} / \mathrm{L})$ (Figure 2 ) observed in the bottom waters of Belize Inlet most closely approach salinity and oxygen concentration values found in stable open shelf environments (Alve, 1995; Alve, 2000; Schafer et al., 1989; Sen Gupta, 1999). The high abundance of Buccella species and C. excavatum, particularly in samples BE1 and BE2, also clearly indicates the open shelf nature of the present day Belize Inlet. Buccella frigida has been observed to be a characteristic species of the open shelf in coastal British Columbia in cool, near shore environments with close to normal salinities (Patterson, 1993; Patterson et al., 2000). Similarly, C. excavatum 
is found in shallow waters of both polar and temperate seas where it appears in cold, normal salinity marine waters (Husum and Hald, 2004; Patterson, 1993; Patterson and Kumar, 2002; Sen Gupta, 1999).

The most abundant species toward the head of Belize Inlet (samples BE3, BE5 and BE7) is $H$. bradyi. This generalist species normally prefers cool muddy environments containing low concentrations of organic matter in waters that are deeper than 50 m (Klitgaard-Kristensen and Buhl-Mortensen, 1999; Murray, 1973). Although $H$. bradyi is well adapted to dysoxic conditions (Sen Gupta and MachainCastillo, 1993) the measured oxygen values $(3 \mathrm{~mL} / \mathrm{L}$ at the time of collection $)$ and the presence of other foraminiferal species that prefer more oxygenated environments, indicates that bottom water oxygen conditions in this part of Belize Inlet consistently remain high enough to maintain the observed fauna (Figure 2). The much lower bottom water oxygen concentration found at both stations ALS1 and ALS3 in Alison Sound is indicated by the presence of foraminiferal faunal Assemblage 1, which is characterized by very low species diversity and is comprised entirely of agglutinated forms. In the ordination triplot diagram (Figure 7) agglutinated species group together in the lowermost left quadrant. The foraminiferal training set developed from the analysis of water property data indicates that any samples and species plotting in this quadrant are tolerant of low oxygen conditions. Conditions at Station ALS3, where an oxygen concentration of $0.06 \mathrm{~mL} / \mathrm{L}$ prevailed, and which plots on the farther corner of this quadrant, typify the environmental significance of this faunal distribution.

Eggerella advena, the dominant species observed in Assemblage 1, is a generalist, tolerant of brackish water conditions and often found in environments 
contaminated by organic matter where oxygen concentrations are frequently low (Blais-Stevens and Patterson, 1998). Eggerella advena is morphologically very similar to Eggerella scabra (Williamson, 1858), a common species in fjords and inner shelves of Northern Europe (Alve and Nagy, 1986). Eggerella scabra is another generalist that seems to have no specific substrate preference, tolerates highly variable organic matter content, and can thrive under very low oxygen concentrations, but the species is most common in environments where salinity ranges from $29-35 \%$ o (Alve and Nagy, 1986). Another common species found in the Assemblage 1 samples from Alison Sound is Cribrostomoides jeffreysii, a species typical of artic waters at depths of between 60 - 360 m (Alves Martins and Ruivo Dragão Gomes, 2004). This species is also tolerant of dysoxic environments $(<0.1 \mathrm{~mL} / \mathrm{L})$, as so is $S$. biformis $(<$ $0.5 \mathrm{~mL} / \mathrm{L} ;$ Sen Gupta and Machain-Castillo, 1993)

The foraminiferal fauna found at Station ALS 2 in Alison Sound is also comprised primarily of agglutinated species. However, it groups together with samples that comprise Assemblage 4 (Figure 5), due to the higher proportion of $B$. frigida present. The shallower water depth of this sample station, coupled with the highest bottom water oxygen concentrations $(1.72 \mathrm{~mL} / \mathrm{L})$ recorded in Alison Sound, account for this mixed assemblage. Bottom water temperatures also play an important role in controlling the distribution of foraminifera in Belize Inlet and Alison Sound. The foraminiferal training set developed from the analysis of water property data indicates that any samples plotting in the right quadrant of the ordination triplot diagram (e.g. samples BE1 and BE2 and the dominant calcareous species found in Belize Inlet; Buccella sp., C. excavatum group, N. labradorica, Lobatula group, I. 
helenae) can be closely correlated with cooler water masses (Figure 7). In contrast, samples from stations BE3, BE5, BE6, BE7, ALS1, ALS2 and ALS3, where bottom water temperatures were measured in 2002 to be above $8.5^{\circ} \mathrm{C}$ (Figures 2 and 3) clustered in the left quadrant of the ordination triplot diagram.

\subsection{Paleoceanographic Changes in Belize Inlet ( AD $900-A D 2002)$}

Utilization of the training set developed based on the surface distribution of foraminifera in Belize Inlet and Alison Sound permitted a high-resolution determination of paleoceanographic change in freeze core FC04 from Belize Inlet. Of particular note was a dramatic and sudden shift from dysoxic/anoxic conditions to well-oxygenated conditions at $\sim$ AD 1495 (77 cm core depth). There has been a steady decline in the level of oxygen in bottom waters through the last century, as dysoxic conditions seem to be slowly redeveloping in the open areas of Belize Inlet.

Several lines of evidence indicate that anoxic and dysoxic conditions prevailed during deposition of the basal portion of FC04 (138 - $77 \mathrm{~cm}$ core depth) that was deposited between $\sim \mathrm{AD} 900$ and $\mathrm{AD} 1495$. The presence of intervals of laminated sediments through portions of the basal section of FC04 indicates the existence of sustained anoxic bottom water conditions, where there would have been few if any intrusions of cold, high oxygen level oceanic water taking place. Similar occurrences of laminated sediments has been documented in many fjord environments where there is little exchange with open oceanic waters, resulting in dysoxic to fully anoxic bottom water conditions (e.g., Effingham Inlet, Vancouver Island, Chang and Patterson, 2005; Havstens and Koljö Fjord, Sweden, Gustafsson 
and Nordberg, 2002; Saanich Inlet, Vancouver Island, Nederbragt and Thurow, 2001; Patterson et al., 2004b; Frederick Sound, SBIC, Wigston, 2006). The presence of these generally non-fossiliferous laminations, coupled with the low diversity, lowoxygen tolerant species of the assemblage found in the more homogeneous sections of this part of the core (Assemblage 1), suggest little exchange with oceanic waters. Results of the transfer function analysis also indicate that oxygen concentration levels were never above $\sim 1 \mathrm{~mL} / \mathrm{L}$ during deposition of this entire unit, except at the base of the core (Figure 8).

There are two possible hypotheses that may explain the presence of anoxic/dysoxic conditions in the bottom waters of Belize Inlet during this interval. First, upwelling may have been suppressed in the area, in which case, the density of ocean waters would have been too similar to the water masses found within the SBIC to favor circulation exchange. However, at present upwelling conditions prevail in the open water areas outside the SBIC and do not penetrate past the restricted entrance at Nakwakto Rapids, where very strong seaward currents dominate (Thomson, 1981). As the bottom waters in the more open areas of the SBIC are currently well oxygenated, this hypothesis is negated. A second possible explanation hinges on the hypothesis that estuarine flow was severely reduced during deposition of the lower unit. This scenario would unfold if precipitation in the area became reduced, resulting in the low salinity layer that forms within the surface waters at present to become poorly developed. This more homogenous water mass would have a reduced tendency to flow toward the open ocean, which in turn would result in a reduction of return flow at depth of denser and well oxygenated subsurface water over the sill at 
Nakwakto Rapids. This reduced flow into the SBIC would have quickly resulted in the development of stagnant bottom-water conditions and a concomitant decrease in oxygen levels, which would have given an ecological advantage to opportunistic foraminiferal species tolerant of low-oxygen concentration (e.g., E. advena, $S$. biformis or Cribrostomoides sp.) Even if full anoxic conditions dominated bottom water conditions for a significant part of the year, some foraminifera are known to be able to survive with only infrequent exposure to oxygenated water (Alve, 2000; Bernhard and Sen Gupta, 2000; Sen Gupta and Machain-Castillo, 1993). The abundance of fecal pellets is very high below $77 \mathrm{~cm}$ in the core, indicating conditions of high productivity in the surface waters, which may also have contributed to the development of reduced oxygen levels at depth. Weak estuarine circulation and high levels of productivity are consistent with a warm, low precipitation climatic regime.

The result of the application of the foraminifera training set derived transfer function to samples from $\mathrm{FCO} 4$ indicates that the estimated paleo-oxygen concentrations and paleo-temperature values were quite stable through the agglutinated foraminifera dominated $138-77 \mathrm{~cm}$ portion of the core (Figure 8). Paleo-oxygen concentration values estimated for this portion of the core ranged from a high of $\sim 2.2 \mathrm{~mL} / \mathrm{L}$ for the lowermost sample, gradually decreasing to $\sim 1 \mathrm{~mL} / \mathrm{L}$ up core. Speculation as to whether this lowermost sampled horizon represents the final phase of a previous interval when elevated oxygen concentrations existed that was not penetrated by $\mathrm{FCO} 4$ is entirely conjectural. The estimated paleo-temperature values remained at a uniform $\sim 8.6^{\circ} \mathrm{C}$ through the entire interval of the core below $77 \mathrm{~cm}$, 
supporting the hypothesis that there was little input of oceanic water during this phase.

The foraminiferal fauna in FCO4 changed significantly in the $76-65 \mathrm{~cm}$ (AD 1495 to $\mathrm{AD}$ 1574) core interval, from a fauna dominated by agglutinated taxa to a calcareous dominated assemblage, albeit comprised primarily of taxa most commonly found under dysoxic conditions. This faunal transition was concomitant with a transfer function derived estimate of oxygen concentration that jumped from $1 \mathrm{~mL} / \mathrm{L}$ in the unit below to $4 \mathrm{~mL} / \mathrm{L}$, and a water temperatures decline from $8.6^{\circ} \mathrm{C}$ to $8.0^{\circ} \mathrm{C}$. This interval is primarily comprised of Assemblage 3, which is dominated by $S$. feylingi, frequently making up more than $50 \%$ of the fauna. The estimated oxygen concentration value of $4 \mathrm{~mL} / \mathrm{L}$ for this interval may be too high though. As discussed below, most species found in Assemblage 3 are dysoxic tolerant generalists, suggesting that the oxygen concentration may have in reality been lower in this interval. A major difficulty for the interpretation of this interval using the transfer function was that there was no close modern analogue with similar abundances of $S$. feylingi in the surface samples examined. For any paleoenvironmental analysis involving a transfer function, the accuracy of paleo-estimates is directly related to the presence of analogues in the training set; the wider the environmental range of samples utilized, the greater the predictive power of the function (Birks et al., 1990; Edwards et al., 2004; Gasse et al., 1995). For the same reason, the validity of the estimated drop in temperature to $8.0^{\circ} \mathrm{C}$ is similarly suspect.

As discussed above, the occurrence of $S$. feylingi has been correlated with low-oxygen environments, appearing even under fully anoxic conditions (Patterson et 
al., 2000; Patterson and Kumar, 2002). Patterson et al., (2000) observed a Stainforthia dominated assemblage under fully anoxic (with $\mathrm{H}_{2} \mathrm{~S}$ ) conditions in Effingham Inlet. Based on this evidence they concluded that even the most isolated basins of that fjord were periodically oxygenated. This hypothesis was later corroborated when long-term monitoring of physical water property data was carried out in Effingham Inlet (Chang and Patterson, 2005; Patterson et al., 2004b). Stainforthia fusiformis (Williamson, 1858), a species closely related to $S$. feylingi, is a typical dweller in fjords of Norway, where it frequently appears as the first recolonizer in formerly anoxic areas (Alve, 1995; Alve, 2000; Alves Martins and Ruivo Dragão Gomes, 2004; Sen Gupta and Machain-Castillo, 1993). This species has also been found to thrive during periods of high primary productivity, which contribute to the organic content of the sediment (Alve, 2000). Other species dominant in this portion of the FCO4 core included $H$. bradyi and $N$. labradorica, which have become adapted to dysoxic conditions due to their infaunal habitat (Sen Gupta and Machain-Castillo, 1993). Research has indicated that $N$. labradorica has accomplished this adaptation through the sequestration of algal chloroplasts in its cytoplasm, though the exact mechanism is unknown (Guilbault et al., 2003). Epistominella vitrea is also common in this core interval and it too has previously been reported as living in dysoxic environments in Swedish fjords (Gustafsson and Nordberg, 2000), although it is also abundant in outer neritic zones along the Pacific and Atlantic coasts where high sedimentation rates prevail (Alves Martins and Ruivo Dragão Gomes, 2004; Patterson, 1993). The overwhelming dominance of S. feylingi and other dysoxia tolerant species indicates that although the environment at the time 
of deposition was dysoxic, oxygen concentrations were higher than in the lower unit of the core. The dramatic increase in the proportion of calcareous species, particularly $S$. feylingi at the lowermost $76 \mathrm{~cm}$ horizon of this interval probably represents, as has been observed elsewhere (e.g., Alve, 1995), a pioneering stage colonization event as the previously stressed very low oxygen environment $(\sim 1$ $\mathrm{mL} / \mathrm{L}$ ) received a prolonged injection of more oxygenated waters and rapidly became habitable for a calcareous foraminiferal assemblage. Another contributing factor to the explosive development of a calcareous fauna at the $76 \mathrm{~cm}$ horizon may have been related to an increase in organic matter in the substrate. The closely related $S$. fusiformis has been observed in Norwegian fjords to double its population in a short period of time following an increase in the input of organic matter and can grow to adult size in less than a month (Gustafsson and Nordberg, 2000). Thus, in addition to the opportunistic colonization of a new ecospace, the sudden abundance peak of $S$. feylingi may therefore also in part be related to the climatological change that was going on at that time as the atmospheric conditions shifted from a dryer to higher precipitation regime. During the transition, conditions may have been optimal for phytoplankton blooms in the surface waters that would have in turn increased the rain of organic material to the bottom of the inlet.

The interval of the core from $75-70 \mathrm{~cm}$ is characterized by the transition from an Assemblage 3 to Assemblage 4 dominated fauna. Although high concentrations of $S$. feylingi are still present in this assemblage, $H$. bradyi is also important. Species of Haplophragmoides are common in muddy shelf environments on both Atlantic and Pacific Ocean coasts (Murray, 1991). The diversity of 
foraminiferal species increases through this zone and may indicate that the faunal succession that was initiated with the first calcareous assemblages at $76 \mathrm{~cm}$ is reaching a climax phase of an ecological succession as bottom water conditions in the inlet changed. A transition back to a more S. feylingi dominated assemblage from 69 $64 \mathrm{~cm}$ in the core indicates that bottom-water circulation patterns during the $\sim 80$ year span of this transitional phase were unstable with intervals of dysoxic and low oxic conditions prevailing.

The foraminiferal faunas found in the interval of FC04 from $64-11 \mathrm{~cm}$ (AD 1574 - AD 1943) are typical of higher oxygenation and colder temperature regimes. The introduction of well oxygenated water at depth was probably triggered by an increase in precipitation within the SBIC catchment area, which is the main variable that influences the extent of the brackish layer within a low run off inlet such as Belize Inlet (Pickard, 1961). Any increase in freshwater input results in development of a thicker brackish surface layer, which, on its way to the sea, entrains a higher amount of deeper saline water that gains velocity towards the mouth of the inlet ( $R$. Thomson, written communication, 2006). The outflow of a large volume of low salinity surface water through the mouth of the SBIC at Nakwakto Rapids results in a return flow over the sill of cold, well oxygenated oceanic water from Queen Charlotte Sound in the subsurface layer. As long as precipitation levels remain high, estuarine flow is enhanced, which keeps oxygen levels in the bottom waters of Belize Inlet high, promoting the development of a diverse and primarily calcareous foraminiferal assemblage. The transfer function reconstruction of oxygen concentrations and average temperature through this interval are $\sim 4.5 \mathrm{~mL} / \mathrm{L}$, and $8.1^{\circ} \mathrm{C}$ respectively, 
which are very similar to conditions in adjacent Queen Charlotte Sound (Thomson, 1981).

The most dominant species, $B$. frigida and $C$. excavatum are species typical in normal open marine cool-water conditions. The range of $C$. excavatum forma clavata is restricted to a high northern latitude belt in both the Pacific and Atlantic Oceans (Sen Gupta, 1999). Nonionella labradorica, present in most samples of this assemblage, has been recorded in sediments from Drammensfjord (Norway) associated with normal saline deep water conditions (Alve, 1991; Gustafsson and Nordberg, 2002). Although, as mentioned before, this species is well adapted to dysoxic conditions because of its ability to use opportunistically the increased organic loads generally associated with dysoxia, it is present in oxic environments as well, although its numbers are often reduced due to competition with other species (Sen Gupta and Machain-Castillo, 1993). Species of Lobatula are also found through this section. These epifaunal suspension feeders are most abundant in environments with good circulation, as the increased oxygen concentrations estimated for this interval suggest (Polyak et al., 2002).

Many foraminiferal specimens recovered from samples through this section were highly etched, to the point of being unrecognizable in many instances, suggesting that dissolution may be a taphonomic biasing factor through this interval of the core. Dissolution of calcareous tests is a process enhanced by macrofaunal reworking of the sediments, which prevents $\mathrm{CaCO}_{3}$ saturation of the porewaters (Green et al., 1993). The etched foraminiferal specimens therefore provide further 
corroborative evidence that a healthy benthos had developed at this site following the increase in levels of oxygenation of the bottom water.

There is an increase in the proportion of agglutinated foraminifera in FC04 in sediments deposited after AD $1943(11-2 \mathrm{~cm})$, suggesting that estuarine circulation began to break down again, with a return to conditions as existed in the inlet in the mid- $16^{\text {th }}$ century, but not as weak, at least as of yet, to conditions that existed prior to AD 1495 (Figure 8). The foraminiferal transfer function indicates that since AD 1943 there has been a decrease in oxygen concentration from above $4 \mathrm{~mL} / \mathrm{L}$ to slightly below, and an increase in temperature of $\sim 0.1^{\circ} \mathrm{C}$ (Figure 8).

A trend similar to that observed in FC04 has been documented in cores from the Skagerrak Basin, NE North Sea (Alve, 1991; Alve, 1996). In that basin there are periodic shifts between agglutinated and calcareous foraminiferal faunas that have been interpreted to reflect varying bottom water oxygenation conditions brought on by infrequent deep water renewal and increased organic matter in the basin.

\section{Thecamoebian Distribution in FC04}

The relatively high abundance of freshwater thecamoebian tests, which are only found in the basal $138-77 \mathrm{~cm}$ interval of the base of the core deposited prior to AD 1495 is difficult to explain. Since thecamoebians are freshwater organisms that cannot survive in salinities higher than 5\%o (Scott et al., 2001), the whole fauna was transported to the basin from soil and freshwater habitats on the margins of the fjord by runoff. The intuitive assumption would be that intervals characterized by higher

numbers of thecamoebians would correspond with periods of higher precipitation, 
conditions that did not exist during deposition of the basal unit of the core. More thecamoebians probably do get washed into the inlet during intervals when precipitation is higher (e.g., the post-77 $\mathrm{cm}$ interval of FC04). However, due to the high velocity of the low salinity surface waters above the pycnocline, they are most likely flushed out of the basin before they have time to settle to the bottom. This hypothesis is based on the observation that the distance that a particle will be carried in a surface water mass will depend on the time that the particle remains in suspension; the faster the velocity of the surface layer, the longer the particles will remain in suspension (Syvitski, 1989). This process has previously been documented in Sandsfjord, Norway, during an analysis of the impact of freshwater runoff on physical oceanography and plankton distribution. Kaartvedt and Svendsen (1990) found that when freshwater runoff increased, due to controlled discharge from a hydroelectric plant at the head of the fjord, the phytoplankton of the upper layers was flushed seawards. Therefore, the absence of freshwater thecamoebians on the SBIC during periods of high estuarine circulation and high precipitation is explained here as the result of them being flushed out of the basin by the high velocity of the surface layer.

\subsection{Paleoclimatic Interpretation}

Changes over time in the position of the respective centers of action (COA; Patterson et al., 2004b) of the AL and NPH strongly influence atmosphere/ocean circulation patterns in the North Pacific region, which in turn affect the amount of rainfall and ultimately streamflow occurring in coastal BC (Cayan and Peterson, 
1989; Trenberth and Hurrel, 1995). Changes in the COA and strength of the AL and NPH may therefore provide a good explanation for the climatic variability observed in the SBIC through the last $\sim 1100$ years. During an interval when the AL was weakened, or when the NPH was stronger, there would have been a diminished estuarine circulation, resulting in a reduced exchange with more open ocean waters, as occurred in the SBIC during the AD 900 - AD 1495 interval. This interval correlates well with the Medieval Warm Episode (MWE). In contrast, periods of a stronger or more persistent AL, accompanied by an increase in precipitation over coastal BC, would have enhanced estuarine circulation within the SBIC, as occurred beginning at $\mathrm{AD} 1495$.

This period of strengthened AL influence that impacted the SBIC between AD 1495 and AD 1943 correlates well with the Little Ice Age (LIA), which has been described as occurring between AD 1500 and 1850 in western Canada (Bradley and Jones, 1995). Though the determination of the initiation of the LIA is controversial, and seems to vary locally, there is a general agreement that the period between the $15^{\text {th }}$ and late $19^{\text {th }}$ century was cooler and/or wetter than at present in most areas of British Columbia. Clague et al., (2004) observed that glaciers from the region were at their greatest extent of the last 3000 years, and perhaps the last 10000 years, during the LIA, and recognized evidence of a gradual climatic amelioration commencing in the $20^{\text {th }}$ century. A second study that utilized varve thickness as a proxy for precipitation in Saanich Inlet, Vancouver Island, also correlated a period of increased precipitation after $\mathrm{AD} 1450$ with the LIA, which ties in with the SBIC record (Nederbragt and Thurow, 2001). 
Analysis of an oxygen isotope record from lacustrine carbonates at Jelly Bean Lake in the Yukon Territory also records similar climatic transitions, although the events there began a little later (ca. AD 1700) and terminated slightly earlier (ca. AD 1900) than observed in the SBIC and other areas to the south (Anderson et al., 2005). The authors correlated the observed sharp transition at $c a$. AD 1700 in the Jelly Bean Lake record with an initial eastward shift of the COA of the AL, which caused precipitation in the area to increase. When the COA of the AL eventually shifted westward again at $c a$. AD 1900 , the amount of precipitation decreased in the area, marking the "end of the LIA".

At the hemispheric scale, there are many similar paleoclimatic proxy records of increased/decreased precipitation through the last millennium that were also influenced by changes in atmosphere-ocean circulation, which can be correlated with both the MWE and the LIA. For example, in the eastern Barents Sea region, there was an extended period of glacial retreat that has been linked to the comparatively mild climate that characterized the MWE in the Northern Hemisphere prior to AD 1400 (Polyak et al., 2004). The subsequent expansion of these glaciers during the LIA was the result of increased precipitation, which in turn originated with an intensification of the Icelandic Low (Polyak et al., 2004). In another study, Lassen et al., (2004) carried out a high-resolution stratigraphic analysis of foraminifera deposited during the last millennium in Igaliku Fjord, South Greenland, which revealed several distinct climatic episodes. Of particular relevance to the present study in the SBIC, where MWE warmer and drier conditions prevailed from AD 900 to AD 1495, Lassen et al., (2004) found evidence of a period of MWE correlated climatic warming and 
increased vertical mixing in the water column that occurred from $\mathrm{AD} 885$ to $\mathrm{AD}$ 1235. The transition at Igaliku Fjord from this warm period to the LIA occurred in two steps, with conditions warming slightly by AD 1520 before a subsequent maximum cooling took place (Lassen et al., 2004). The results from the SBIC provide further evidence that the MWE and the LIA were at least hemispheric phenomena, although the timing of initiation and termination seems to vary.

Although the present record is too short to indicate climatic fluctuations on a centennial scale, it is possible that the period between 1574 and 1943 corresponds to a well documented $\sim 500$ years solar cycle. This cycle between lower and higher solar irradiance levels have been correlated with wetter/drier conditions and an intensified/weakened AL (Patterson et al., 2004b). The cycle is prevalent in the Northern Hemisphere (Hu et al., 2003), and it broadly matches the LIA and Medieval Warm Period in the North Atlantic (Bond et al., 2001).

\section{Conclusions}

High resolution analysis of Recent and fossil foraminifera from the SBIC has provided evidence of the both the MWE and LIA. The presence of these global climate phenomena in coastal BC seems to have been controlled in large part by the relative strength, and long-term migration of the COA's of both the NPH and AL. Reduced precipitation in the SBIC catchment during the MWE from AD $900-$ AD 1495 resulted in weakened estuarine circulation and the development of dysoxic and anoxic conditions in the bottom waters as indicated by the low diversity agglutinated foraminiferal fauna characterizing this interval. There was a major increase in 
precipitation in the SBIC area after AD 1495 as the COA of the AL migrated eastward. This change in atmospheric - ocean circulation is marked in the core by a transitional interval that terminates by $\mathrm{AD} 1574$. Conditions during this $\sim 80$ year transitional interval varied though as there were not only episodes when cold, well oxygenated water entered the fjord but episodes when anoxia prevailed as well. Strong estuarine circulation permanently prevailed in the SBIC after AD 1574 as reflected by almost the diverse calcareous foraminiferal fauna in the core. Estuarine circulation seems to be weakening in the post AD 1943 interval suggesting a possible future return to conditions that prevailed during the MWE, although precipitation levels and bottom water oxygen levels are not as low yet in the SBIC as they were during the $10^{\text {th }}-15^{\text {th }}$ centuries.

The present study shows the potential of high resolution foraminiferal research in the development of accurate climate chronologies. Cluster analysis proves to be a resourceful qualitative tool in the description of assemblages, and ordination methods are useful to determine the environmental factors affecting those assemblages. The use of transfer functions has great potential, both as a validation of previously defined clusters and as a quantitative instrument to estimate past values of environmental variables.

\section{Systematic paleontology}

Suprageneric classification follows that of Loeblich and Tappan (1987). Illustrated specimens are housed in the Department of Earth Sciences, Carleton University, Ottawa, Ontario. 
Order FORAMINIFERIDA Eichwald, 1830

Suborder TEXTULARIINA Delage and Hérouard, 1896

Superfamily ASTRORHIZACEA Brady, 1881

Family SACCAMMINIDAE Brady, 1884

Subfamily SACCAMMININAE Brady, 1884

Genus Saccammina Carpenter, 1869

Saccammina atlantica (Cushman, 1944)

Proteonina atlantica CUSHMAN, 1944, p. 5, Pl. 1, fig. 4.

Saccammina atlantica (Cushman, 1944). RODRIGUES, 1980, p. 69, PI. 3-1, fig. 11.

Saccammina cf. atlantica (Cushman, 1944). BLAIS, 1995, p. 92, Pl. 2.3, fig. 4.

Description: test free, single elongate, oval or pyriform chamber; wall agglutinated, fairly coarse; aperture very small, at tapered end of chamber; no distinct neck, but gradually contracted toward apertural end; circular in section.

Saccammina sphaerica Sars, 1872

Saccammina sphaerica SARS, 1872, p. 250, figure in Carpenter, 1875, p. 532, fig. 272; HÖGLUND, 1947, p. 50, Pl. 3, fig. 7; SCHRÖDER, 1986, p. 37, Pl. 10, fig. 4; JONASSON, 1994, p. 47, Pl. 2, fig. 5.

Description: test free, single globular chamber, spherical or pyriform; wall agglutinated, fine, smooth; aperture rounded, may be nearly flush or on short neck; inner organic wall layer modified in living specimens to an oral apparatus or entosolenian tube around opening.

Superfamily AMMODISCACEA Reuss, 1862

Family AMMODISCIDAE Reuss, 1862 


\title{
Subfamily AMMOVOLUMMININAE Chernykh, 1967
}

\author{
Genus Ammodiscus Reuss, 1862
}

Ammodiscus gullmarensis Höglund, 1948

Plate 1, figure 1

Ammodiscus planus HÖGLUND, 1947, p. 123, Pl. 8, fig. 2,3,8; Pl. 28, fig, 17,18.

Ammodiscus gullmarensis HÖGLUND, 1948, p. 45.

Description: test free, small, flattened but tending to irregular coiling in last whorls; wall arenaceous with fairly large amount of cement; 7 to 9 whorls; sutures distinct, proloculum central and subspherical.

Superfamily RZEHAKINACEA Cushman, 1933

Family RZEHAKINIDAE Cushman, 1933

Genus Miliammina Heron-Allen and Earland, 1930

Miliammina fusca (Bradyi, 1870)

Quinqueloculina fusca BRADY, in BRADY and ROBERTSON, 1870, p. 286, pl. 11, fig. 2.

Miliammina fusca (Brady, 1870) MURRAY, 1971, p. 21, Pl. 3, fig. 1-6; PATTERSON, 1990, p. 240, pl. 1, fig. 4.

Description: test elongate ovate; narrow chambers one-half coil in length, quinqueloculine arrangement; wall thick, very finely agglutinated; aperture at end of chamber, large and conspicuous, equal in size to transverse section of chamber.

Superfamily HORMOSINACEA Haeckel, 1894

Family HORMOSINIDAE Haeckel, 1894

Subfamily REOPHACINAE Cushman, 1910 
Genus Reophax de Montfort, 1808

Reophax catella Höglund, 1947

Plate 4, figure 3

Reophax catella HÖGLUND, 1947, p. 97, fig. 77,78; ALVE, 1990, p. 693, Pl. 1, fig. $16,18$.

Leptohalysis catella (Höglund, 1947). BLAIS, 1995, p. 91, Pl. 2-1, fig. 6.

Description: test free, elongate, slender, tapering, circular in section; wall agglutinated, thin; numerous (up to 20) chambers, increasing in size, arranged in straight line or slightly curved; chambers short and broad, height equaling or slightly exceeding the breadth, chamber sides convex, slightly converging upward, contact surface between chambers broad; aperture a simple rounded opening at top of chamber.

\section{Reophax gracilis (Kiaer, 1900)}

Nodulina gracilis KIAER, 1900, p. 24, fig. 1,2.

Reophax gracilis (Kiaer, 1900). ALVE, 1990, p. 693, Pl. 1, fig. 17.

Description: test free, elongate, composed of about 19 loosely sutured segments, at the outset short and wide, becoming elongated and pointed towards top, with almost horizontally sectioned basal parts; wall agglutinated, smooth.

Remarks: $R$. gracilis is differentiated of $R$. catella and $R$. scottii by basal part of its chambers, which look almost horizontally sectioned.

Reophax scottii Chaster, 1892

Reophax scottii CHASTER, 1892, p. 57, Pl.1, fig. 1; MURRAY, 1971, p. 17, Pl. 1, fig. 6-8; ALVE, 1990, p. 693, Pl. 1, fig. 19. 
Description: test free, elongate, narrow; wall agglutinated, very delicate, transparent, flexible when moist; 10-20 chambers arranged in a line, gradually increasing in size; chambers somewhat pyriform, abruptly truncated below; aperture small.

\author{
Superfamily LITUOLACEA de Blainville, 1827 \\ Family HAPLOPHRAGMOIDIDAE Maync, 1952 \\ Genus Cribrostomoides Cushman, 1910 \\ Cribrostomoides crassimargo (Norman, 1892) \\ Plate 1, figure 2
}

Haplophragmium crassimargo NORMAN, 1892, p. 17, Pl. 7-8.

Labrospira crassimargo (Norman, 1892). HÖGLUND, 1947, p. 141, P1, 11, fig. 1.

Alveolophragmium crassimargo (Norman, 1892). LOEBLICH and TAPPAN, 1953, p. 29, Pl. 3, fig. 1-3.

Cribrostomoides crassimargo (Norman, 1892). TODD and LOW, 1967, p. 15, Pl. 1, fig. 24.

Description: test free, planispiral, partially involute; wall agglutinated, thick, coarse, with large sand grains, sometimes of orange color; 2 to 4 whorls, 8 to 10 chambers in last whorl; sutures straight, slightly depressed; umbilicus depressed; periphery rounded, lobulate; aperture interio-aereal, forming an oblong, curved slit, upper and lower lip well developed

Cribrostomoides jeffreysii (Williamson, 1858)

Plate 1, figures $4 a-c$

Nonionina jeffreysii WILLIAMSON, 1858, p. 34, Pl. 3, fig. 72,73. 
Alveolophragmium jeffreysii Williamson, 1858. LOEBLICH and TAPPAN, 1953, p. 31, Pl. 3, fig. 4-7.

Cribrostomoides jeffreysii (Williamson, 1858). MURRAY, 1971, p. 23, Pl. 4, fig. 1-5. Description: test free, planispiral, almost involute, compressed laterally; wall finely agglutinated, yellow to brown; 6 to 8 chambers in last whorl, with triangular shape; periphery rounded, slightly lobulate; sutures depressed and radial; aperture a lipped slit near base of apertural face.

Cribrostomoides cf. subglobosum (Cushman, 1910a)

Plate 1, figures 5a-b

Haplophragmoides subglobosum CUSHMAN, 1910, p. 105, fig. 162-164.

Labrospira subglobosa (Cushman, 1910). HÖGLUND, 1947, p. 144, Pl. 11, fig. 2.

Cribrostomoides subglobosus (Cushman, 1910). SCHRÖDER, 1986, p. 48, Pl. 17, fig. 15, 16; JONASSON, 1994, p. 53, Pl. 5, fig. 8.

Cribrostomoides subglobosum (Cushman, 1910a). POAG, 1981, p. 57, Pl. 11, fig. 2.

Description: test free, planispiral, involute, depressed at the umbilicus; wall agglutinated, somewhat roughened but variable; chambers broad and low, usually 4 to 8 in last whorl, making test as whole subglobular; aperture interio-aereal, forming oblong, very narrow curved slit immediately above of inner margin of apertural face, with well developed lips.

Remarks: although $C$. subglobosum is reported to be of a bigger size than the specimens present on the SBIC (J. P. Guilbault, oral communication, 2006), the general shape of these specimens agrees well with the description of C. subglobosum. However, the apertural face in most specimens was covered by debris, making 
impossible to recognize the shape of the aperture. They are therefore named as $C$. cf. subglobosum, until a better designation is found.

Cribrostomoides wiesneri (Parr, 1950)

Plate 2, figures 1a-c

Labrospira wiesneri PARR, 1950, p. 272, P1. 4, fig. 25, 26.

Cribrostomoides wiesneri (Parr, 1950). SCHRÖDER, 1986, p. 48, Pl. 17, fig. 10, 12; POAG, 1981, p. 57, Pl. 9, fig. 1.

Description: test free, planispiral, not completely involute; wall agglutinated, fine, with excess of yellow to reddish brown cement, smooth; umbilical region depressed, with chambers of earlier whorls visible; about 3 whorls; periphery slightly lobulate; 7 to 9 chambers in last whorl; sutures distinct, slightly depressed; aperture a short narrow slit slightly above base of apertural face.

\section{Cribrostomoides sp. A}

Plate 1, figures $3 \mathrm{a}, 3 \mathrm{~b}$

Description: test free, planispiral, involute, depressed at the umbilicus; wall agglutinated, somewhat roughened but variable; chambers broad and low, usually 5 to 7 in last whorl; last chamber much inflated and wider, protruding strongly on both sides on apertural view, rest of the chambers more compressed; periphery rounded; aperture interio-aereal, forming a curved slit immediately above of inner margin of apertural face.

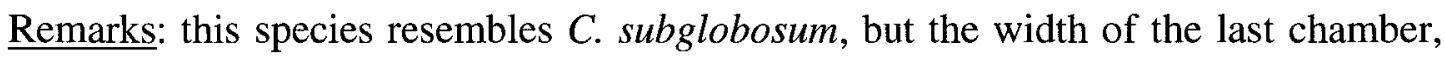
very prominent in all specimens, sets it apart.

Genus Haplophragmoides Cushman, 1910 
Haplophragmoides bradyi (Brady, 1887)

Plate 1, figures $6 \mathrm{a}-\mathrm{c}$

Trochammina robertsoni BRADY, 1887, p. 893, Pl, 20, fig. 4.

Trochammina bradyi ROBERTSON, 1891, p. 388.

Haplophragmoides bradyi (Brady, 1887). HÖGLUND, 1947, p. 134, Pl. 10, fig. 1; MURRAY, 1971, p. 24, Pl, 5, fig. 1,2; SCHRÖDER, 1986, p. 46, Pl. 17, fig. 8.

Description: test free, planispiral, partly evolute, discoidal or compressed, nearly symmetrical bilaterally; wall agglutinated, very fine, brown, very smooth; 5 chambers in outer whorl, somewhat inflated; sutures distinct, depressed; aperture interiomarginal, lipped.

Superfamily HAPLOPHRAGMIACEA Eimer and Fickert, 1899

Family AMMOSPHAEROIDINIDAE Cushman, 1927

Subfamily RECURVOIDINAE Alekseychik-Mitskevich, 1973

Genus Recurvoides Earland, 1934

Recurvoides turbinatus (Brady, 1881)

Plate 1, figures $7 \mathrm{a}, \mathrm{b}$

Lituola (Haplophragmium) turbinatum BRADY, 1881, p. 50, P1. 35, fig. 9.

Recurvoides turbinatus (Brady, 1881). LOEBLICH and TAPPAN, 1953, p. 27, Pl. 2, fig. 11; RODRIGUES, 1980, p. 66, P1. 3-3, fig. 8; JONASSON, 1994, p. 58, P1. 7, fig. 2.

Description: test free, streptospiral, involute on one side and evolute on the other; wall agglutinated, somewhat roughened but variable; chambers not inflated but 
somewhat irregular in shape; periphery rounded; aperture an elongated aereal slit set at an angle on periphery.

Superfamily SPIROPLECTAMMINACEA Cushman, 1927

Family SPIROPLECTAMMINIDAE Cushman, 1927

Subfamily SPIROPLECTAMMININAE Cushman, 1927

Genus Spiroplectammina Cushman, 1927

Spiroplectammina biformis (Parker and Jones, 1865)

Plate 4, figures 6a-c

Textularia agglutinans d'Orbigny var. biformis PARKER and JONES, 1865, p. 370, Pl. 15, fig. 23, 24.

Spiroplectammina biformis (Parker and Jones, 1865). HÖGLUND, 1947, p. 163, P1. 12, fig. 1; LOEBLICH and TAPPAN, 1953, p. 34, Pl. 4, fig. 1-6; SCHRÖDER, 1986, p. 51, Pl. 21, fig. 14 .

Description: test free, elongate, narrow, ovoid in section, margins broadly rounded, sides nearly parallel; wall agglutinated, solid; large early planispiral coil of few chambers followed by biserially arranged chambers, coil commonly of greater breadth than first few parts of biserial chambers; chambers very slightly inflated; sutures somewhat indistinct, only slightly depressed; aperture a low arch at inner margin of final chamber.

Superfamily TROCHAMMINACEA Schwager, 1877

Family TROCHAMMINIDAE Schwager, 1877

Subfamily TROCHAMMININAE Schwager, 1877

Genus Portatrochammina Echols, 1971 
Portatrochammina bipolaris BRÖNNIMANN and WHITTAKER, 1980, pp. 181, 183, fig. $15,16,18,19,20-31$.

Description: test free, trochospiral; wall agglutinated, imperforate; about 14 chambers, 6 to 8 chambers in the final whorl, increasing rapidly in size; shallow umbilicus covered by flap from each successive chamber; elongate-ovate in outline, final portion somewhat lobulate; compressed, almost flat spirally, concave umbilically; periphery rounded to sub-acute; final chamber characteristically flat on spiral side and strongly convex on umbilical side; radial sutures straight to sinuous on umbilical side and slightly curved on spiral side; color dark brow grading into light brown; aperture begins as low interiomarginal opening near periphery, extends as slit around umbilical flap.

Genus Trochammina Parker and Jones, 1859

Trochammina charlottensis Cushman, 1925

Plate 2, figures $4 \mathrm{a}-\mathrm{c}$

Trochammina charlottensis CUSHMAN, 1925, p. 39, Pl. 6, fig. 4a, b.

Trochammina charlottensis CUSHMAN, 1925. BLAIS, 1995, p. 92, Pl. 2-3, fig. 1; PATTERSON, BURBIDGE and LUTERNAUER, 1998, p. 4, Pl. 26, fig. 5,6.

Description: test free, compressed, very flat trochospiral; wall coarsely agglutinated, opaque; sutures radiate and depressed, especially on the umbilical side; all chambers visible on spiral side, last 6 chambers visible on the umbilical side; aperture a low interiomarginal arch opening into the open umbilicus. 
Remarks: this species is easily distinguishable by the very big, inflated last chamber.

Trochammina discorbis Earland, 1934

Plate 2, figures 6a-c; Plate 3, figure 4

Trochammina discorbis EARLAND, 1934, p. 104, Pl. 3, fig. 28-31; BLAIS, 1995, p. 93, Pl. 2-3, fig. 7, 8.

Description: test free, minute, trochospiral; wall agglutinated, very fine with much cement; surface smooth but not very highly polished; 3 or 4 whorls visible on spiral side, 4 or 5 chambers from final whorl visible on dorsal side; dorsal side highly convex, umbilical side nearly flat but with deeply sunk umbilicus; sutures recurved on dorsal side, straight on ventral; periphery subacute; aperture small slit on inner edge of final chamber on ventral side.

Trochammina globigeriniformis (Parker and Jones, 1865)

Plate 3 , figures $7 \mathrm{a}, \mathrm{b}$

Lituola nautiloidea var. globigeriniformis PARKER and JONES, 1865, p. 40.7, Pl. 15, fig. 46,47 .

Trochammina cf. globigeriniformis (Parker and Jones, 1865). SCHRÖDER, 1986, p. 52, P1. 19, fig. 5-8.

Description: test free, trochospiral, varying from depressed to slightly conical; wall medium to coarsely arenaceous with finer grained matrix; 2 or 3 whorls; chambers rapidly increasing in size; periphery rounded; aperture simple at inner margin on umbilical side of last chamber opening into narrow umbilicus.

Trochammina grisea Earland, 1934 
Trochammina grisea EARLAND, 1934, p. 100, P1. 3, fig. 35-37.

Description: test free, large, trochospiral; wall agglutinated, fine, smooth, unpolished; 3 whorls with 6 chambers each on dorsal side, only 6 last chambers visible on umbilical side, very slightly inflated; dorsal side flattened, umbilical side deeply depressed at umbilicus; sutures on dorsal side straight and distinct, slightly depressed, sutures more depressed on umbilical side; periphery round, slightly lobulate at last few chambers; aperture a narrow slit on inner apertural face of last chamber.

Trochammina inflata (Montagu, 1808)

Plate 2, figures 2a, b

Nautilus inflatus MONTAGU, 1808, p. 81, Pl. 18, fig. 3

Trochammina inflata (Montagu, 1808). MURRAY, 1971, p. 35, Pl. 10, fig. 3-6; PATTERSON, 1990, p. 241, Pl. 1, fig. 8-10.

Description: test free, trochospiral; wall very finely arenaceous, very smoothly finished; 2 or 3 whorls, with 4 to 5 chambers in last whorl; chambers extremely inflated; periphery rounded; sutures distinct but only slightly depressed, nearly radial; aperture a narrow slit on ventral side, at base of last-formed chamber.

Trochammina nana (Brady, 1881)

Plate 2, figures $5 a, b$

Haplophragmium nana BRADY, 1881, p. 50; BRADY, 1884, p. 311, pl. 35, fig. 6-8;

Trochammina nana (Brady, 1881). LOEBLICH and TAPPAN, 1953, p. 50, Pl. 8, fig. 5; PATTERSON, BURBIDGE and LUTERNAUER, 1998, p. 4, Pl. 1, fig. 1-3.

Description: test free, trochospiral, with spiral side almost flattened and umbilical side more convex; wall agglutinated, opaque, of medium-size grains, with some larger 
clear quartz grains, quite smooth; lobulate periphery; two-and-one-half whorls, all chambers visible on spiral side, only final 6 or 7 visible on umbilical side; chambers somewhat inflated; sutures distinct, nearly straight and radiate ventrally, curving backwards to periphery on dorsal side; aperture low interiomarginal arch extending into very open umbilicus.

Trochammina nitida Brady, 1881

Plate 3, figures $1 \mathrm{a}, \mathrm{b}$

Trochammina nitida BRADY, 1881, p. 52, figure in Brady, 1884, Pl. 41, fig. 5, 6; SNYDER, HALE and KONTROVITZ, 1990, p. 277, Pl. 7, fig. 3.

Description: test free, low trochospiral, compressed; wall agglutinated, thin and fragile; 2 or 3 whorls on dorsal side, final whorl with 9 chambers, increasing rapidly in size as added; dorsal side flat, umbilical side convex, somewhat excavated at umbilicus; periphery rounded, slightly depressed at sutures; aperture a curved or angled slit, beginning at base of apertural face in equatorial position and curving openly upward onto umbilical side of chamber.

Trochammina ochracea (Williamson, 1858)

Plate 3, figures 3a-c

Rotalina ochracea WILLIAMSON, 1858, p. 55, Pl. 5, fig. 113.

Lepidodeuterammina ochracea (Williamson, 1858). LOEBLICH and TAPPAN, 1987, Pl. 135, fig. 10-14.

Trochammina ochracea (Williamson, 1858). MURRAY, 1971, p. 37, Pl. 11, fig. 1-5;

ALVES MARTINS and RUIVO DRAGÃO GOMES, 2004, p. 29, fig. 2.12. 
Description: test free, trochospiral, depressed; wall agglutinated; two-and-one-half whorls in dorsal side, with 8 or 9 chambers each, filled with dark organic matter on umbilical side; slightly convex on dorsal side, correspondingly concave on ventral side; periphery round, very slightly lobulate at last chambers; sutures sometimes raised, arcuate, flexuous and very prominent; aperture a peripheral interiomarginal arch, secondary umbilical apertures at umbilical inflated portions of chambers.

Trochammina pacifica Cushman, 1925

Plate 3, figures 5a-d

Trochammina pacifica CUSHMAN, 1925, p. 39, Pl.6, fig. 3; PATTERSON, 1990, p. 240, Pl. 1, fig. 5-7; SNYDER, HALE and KONTROVITZ, 1990, p. 273, Pl. 5, fig. 1; BLAIS, 1995, p. 93, Pl. 2.2, fig. 7-8.

Description: test free, trochospiral; wall coarsely arenaceous, smoothly finished; 2 or 3 whorls, with 4 to 5 chambers in last whorl; chambers extremely inflated; periphery rounded; sutures distinct but only slightly depressed, nearly radial; aperture a narrow slit on ventral side, at base of last-formed chamber.

Trochammina rotaliformis Heron-Allen and Earland, 1911

Plate 3, figures $6 a, b$

Trochammina rotaliformis HERON-ALLEN and EARLAND, 1911, p. 309; LOEBLICH and TAPPAN, 1953, p. 51, Pl. 8, fig. 6-9; MURRAY, 1971, p. 39, Pl. 12, fig. 1-5; BLAIS, 1995, p. 93, Pl. 2-3, fig. 1-3.

Description: test free, trochospiral; wall agglutinated, imperforate; 20 elongated chambers arranged in 3 whorls on dorsal side, 5 chambers broadly triangular on umbilical side; strongly convex on dorsal side, shallow-concave on umbilical side; 
periphery rounded, slightly lobulate; sutures not well defined, more depressed on umbilical side; umbilical depression start-shaped, open and deep with 5 arms; primary aperture interiomarginal extraumbilical, secondary posterior aperture umbilicalsutural.

Trochammina squamata Jones and Parker, 1860

Plate 3, figures 2a, b

Trochammina squamata JONES and PARKER, 1860, fig. in HEDLEY, HURDLE and BURDETT, 1964, p. 422, fig. 1, p. 424, fig. 1-3.

Trochammina astrifica Rhumbler, 1938. HÖGLUND, 1947, p. 206, Pl. 15, fig. 2.

Trochammina squamata Jones and Parker, 1860. SNYDER, HALE and KONTROVITZ, 1990, p. 279, Pl. 8, fig. 1.

Description: test free, small, low trochoidal, excavated on umbilical side; wall finely arenaceous, with occasional larger grains, smoothly finished; periphery angular in outline, slightly lobulate; chambers not inflated, lunate shaped; 2 whorls visible on spiral side; sutures distinct, apparently flush with surface of test, visible on spiral side as dark brown curved backwards lines; aperture a narrow slit at inner margin of umbilical side of last chamber.

Superfamily VERNEULINACEA Cushman, 1911

Family VERNEULINIDAE Cushman, 1911

Subfamily VERNEULININAE Cushman, 1911

Genus Gaudryina d'Orbigny, 1939

Gaudryina arenaria Galloway and Wissler

Plate 4, figure 1 
Gaudryina arenaria GALLOWAY and WISSLER, 1927, p. 68, Pl. 11, fig. 5; PATTERSON, BURBIDGE and LUTERNAUER, 1998, p. 5, Pl. 1, fig. 6,7.

Description: test free, elongate, of equal with for much of the test length, tapers to base; wall agglutinated, finely perforate, opaque, surface roughened; chambers initially triserial and triangular in cross-section, then become biserial and slightly inflated; sutures indistinct in triserial section, become depressed in biserial portion; aperture arched at base of final chamber.

Superfamily TEXTULARIACEA Ehrenberg, 1838

Family EGGERELLIDAE Cushman, 1937

Subfamily EGGERELLINAE Cushman, 1937

Genus Eggerella Cushman, 1935

Eggerella advena (Cushman, 1922)

Plate 4, figures 4a-d

Verneuilina advena CUSHMAN, 1922, p.141.

Eggerella advena (Cushman, 1922). LOEBLICH and TAPPAN, 1953, p. 36, Pl. 3, fig. 8-10; PATTERSON, BURBIDGE and LUTERNAUER, 1998, p. 5, Pl. 28 , fig. 6. Description: test free, elongate, sharply tapering, early portion with 4 to 5 chambers in a whorl, later portion triserial; wall finely agglutinated with occasional larger grains; chambers numerous, low and broad in early portion, increase in relative height as added, those of final whorl approximately equal in height and breadth; sutures distinct and depressed; aperture small, central, low arch at base of final chamber.

Eggerella belizensis n. sp.

Plate 4, figures 5a-d 
Eggerella advena (Cushman, 1922). RESIG, 1963, p. 125, fig. 2.

Diagnosis: a species of Eggerella with triangular cross-section and inflated last chambers.

Description: test free, elongate, sharply tapering, early portion with 4 to 5 chambers in a whorl, later portion triserial, triangular in cross-section; wall finely agglutinated with occasional larger grains; normally 4 to 5 whorls; chambers numerous, low and broad in early portion, increasing slowly in relative height as added, normally three chambers in final whorl, very inflated and extending outwards of the axis of the test, giving the test a triangular outline in apertural view and an almost flat apertural face; sides straight, except for sutures, increasing at $25^{\circ}$ from the axis; sutures distinct and depressed; aperture small, central, low arch at base of final chamber, sometimes with a narrow lip.

Etymology: from Belize Inlet, British Columbia, Canada, and -ensis, denoting place, locality.

Types and occurrences: holotype collected from freeze core FC04, collected from Belize Inlet in the Seymour-Belize Inlet Complex, in the coast of British Columbia, $51^{\circ} 7.90^{\prime} \mathrm{N}, 127^{\circ} 9.02^{\prime} \mathrm{W}$, at a depth of $274 \mathrm{~m}$.

Remarks: Eggerella belizensis appears together with E. advena (Cushman), although the latter is easily differentiated by the tapering of the final chambers and the more elongated test, as well as by the last chambers being equal in height and width, while the ones of $E$. belizensis are more inflated and shorter. The test of $E$. advena is narrower, with a smaller angle with respect to the longitudinal axis. Eggerella belizensis is most similar to Eggerella scabra (Williamson, 1858), a species known 
from European waters; however, it is differentiated by the more elongated test shape and globular chambers of the latter. Eggerella belizensis has been described from the shelf of Washington State as a short morphotype of Eggerella advena present in deep waters (Resig, 1963). Harmon (1972) described, but did not illustrate, two morphotypes of E. advena, one of which seems to correspond with E. belizensis. Members of $E$. belizensis and $E$. advena found within the SBIC have the same size, indicating that $E$. belizensis is not a juvenile form.

Family TEXTULARIIDAE Ehrenberg, 1838

Subfamily TEXTULARIINAE Ehrenberg, 1838

Genus Textularia Defrance, 1824

Textularia earlandi Parker, 1952

Plate 4, figures $2 a, b$

Textularia earlandi PARKER, 1952, new name for Textularia tenuissima Earland, 1933, p. 95, Pl. 3, fig. 21-40; MURRAY, 1971, p. 33, Pl. 9, fig. 1-5; BLAIS, 1995, p. 92, Pl. 2-2, fig. 1

Description: test minute, very elongate, biserial, straight or slightly curved, oval in section, tapering very gradually to the oral, thickest portion; wall agglutinated, thin, smooth, with little sign of cement; periphery straight in first half of test, then slightly lobulate, rounded throughout; chambers very numerous, distinct, regularly increasing in size and thickness, finally becoming slightly inflated; sutures distinct, depressed; aperture an interiomarginal arch, distinct.

Suborder MILIOLINA Delage and Hérouard, 1896 Superfamily CORNUSPIRACEA Schultze, 1854 
Family HAUERINIDAE Schwager, 1876

Subfamily HAUERININAE Schwager, 1876

Genus Quinqueloculina d'Orbigny, 1926

Quinqueloculina sp.

Description: test ovate in outline; wall calcareous, imperforate, porcelanous; aperture ovate, flush with surface; chambers quinqueloculine, one-half coil in length, five chambers visible from exterior.

$\underline{\text { Remarks: }}$ the specimens were too badly preserved to identify to species level.

Superfamily NODOSARIACEA Ehrenberg, 1838

Family NODOSARIIDAE Ehrenberg, 1838

Subfamily NODOSARIINAE Ehrenberg, 1838

Genus Dentalina Risso, 1826

Dentalina ittai Loeblich and Tappan, 1953

Plate 5, figures 1a, b

Dentalina ittai LOEBLICH and TAPPAN, 1953, p. 56, Pl. 10, fig. 10-12; RODRIGUES, 1980, p. 150, Pl. 3-7, fig. 6.

Description: test free, narrow, elongate, arcuate; 2 to 6 elliptical chambers, nearly equal in diameter, slightly overlapping; sutures distinct, constricted, straight; wall calcareous, finely perforate, translucent, so that neck and aperture of earlier chambers may be seen through wall of following chamber, surface smooth and unornamented; aperture radiate, terminal and central in position, very slightly produced.

Suborder LAGENINA Delage and Hérouard, 1896

Superfamily NODOSARIACEA Ehrenberg, 1838 
Family LAGENIDAE Reuss, 1862

Genus Hyalinonetrion Patterson and Richardson, 1988

Hyalinonetrion dentaliforme (Bagg, 1912)

Plate 5, figure 10

Lagena dentaliformis BAGG, 1912, p. 45, Pl. 13, fig. 1,2.

Hyalinonetrion dentaliforme (Bagg, 1912). PATTERSON, BURBIDGE and LUTERNAUER, 1998, p. 8, Pl. 2, fig. 9.

Description: test free, large, elongate, circular in cross-section, tapers at ends; wall calcareous, hyaline, smooth, finely perforate, although pores do not penetrate outer wall; aperture small and circular with phialine lip.

Genus Lagena Walker and Jacob, 1798

Lagena laevis (Montagu, 1803)

Plate 5, figures 3a, b

Vermiculum leave MONTAGU, 1803, p. 524.

Lagena laevis (Montagu, 1803). LOEBLICH and TAPPAN, 1953, p. 61, Pl. 11, fig. 5-8; MURRAY, 1971, p. 83, Pl. 32, fig. 6, 7.

Description: test free, unilocular, flask-shaped, somewhat elongate, widest slightly below midportion of test, base rounded; wall calcareous, hyaline, finely perforate, surface smooth except occasionally very slightly and finely hispid at base, but without distinct spines; upper portion of test tapering gradually to very elongate and slender neck; rounded aperture at top of neck.

Lagena meridionalis Wiesner, 1931

Plate 5, figures $4 a, b$ 
Lagena gracilis var. meridionalis Wiesner, 1931, p. 117, Pl. 18, fig. 211

Lagena meridionalis Wiesner, 1931. TODD and LOW, 1967, p. 24, Pl. 3, fig. 21.

Description: test free, unilocular, minute, flask-shaped, wider near rounded base, tapering into long, slender neck; wall calcareous, hyaline, finely perforate, surface ornamented with longitudinal costae, of which every second one is shorter, stopping at the base of the neck, the long costae extend onto neck; aperture simple, terminal, rounded.

Lagena parri Loeblich and Tappan, 1953

Lagena laevis (Montagu) var. baggi CUSHMAN and GRAY, 1946, p. 18, Pl. 3, fig. $26,27$.

Lagena parri LOEBLICH and TAPPAN, 1953, p. 64, Pl. 11, fig. 11-13.

Description: test free, unilocular, flask-shaped to ovate, widest in lower half of test, with single distinct basal spine; long, very slender neck; wall calcareous, hyaline, finely perforate, smooth; aperture terminal at top of delicate neck.

Lagena semilineata Wright, 1886

Plate 5, figures 5a, b

Lagena semilineata WRIGHT, 1886, p. 320, Pl. 26, fig. 7; LOEBLICH and TAPPAN, 1953, p. 65, Pl. 11, fig. 14-22.

Description: test free, unilocular, flask-shaped, widest near apiculate base, somewhat tapered at upper portion and grading into very long, slender, delicate neck; wall calcareous, hyaline, finely perforate, upper one-half to two-thirds of test is smooth, lower portion ornamented with fine costae, which double in number by intercalation a short distance from the base, in occasional specimens intercalary costae do not 
develop; delicate basal spine of about one-half the diameter of neck, sometimes broken; neck long, slender, length about two-thirds of chamber; aperture terminal at end of neck, surrounded by slight lip.

Genus Procerolagena Puri, 1953

Procerolagena cf. amphora (Reuss, 1862)

Plate 5, figures 9a, b

Lagena amphora REUSS, 1862, p. 330, Pl. 4, fig. 57; TODD and LOW, 1967, p. 23. Description: test free, unilocular, big, amphora-shaped, elongate, tapering into long, slender neck; wall calcareous, hyaline, finely perforate, surface ornamented with thick, longitudinal, plate-like costae that extend onto neck; aperture simple, terminal, rounded, with phialine lip.

Procerolagena gracilis (Williamson, 1848)

Plate 5, figure 7

Lagena gracilis WILLIAMSON, 1848, p. 13, Pl. 1, fig. 5

Procerolagena gracilis (Williamson, 1848). PATTERSON, BURBIDGE and LUTERNAUER, 1998, p. 9, P1. 6, fig. 1.

Description: test free, unilocular, elongate, circular in cross-section, widest near midpoint; wall calcareous, hyaline; 16 to 20 discontinuous and occasionally anastomosing longitudinal costae that extend from base to neck, in some specimens costae unite to form an elongate process in aboral region; neck narrow and elongate, comprises less than one-half of test length; aperture small and circular with phialine lip.

Procerolagena mollis (Cushman, 1944) 
Plate 5, figure 6

Lagena gracillima (Seguenza) var. mollis CUSHMAN, 1944, p. 21, Pl. 3, fig. 3.

Lagena mollis (Cushman, 1944). LOEBLICH and TAPPAN, 1953, p. 63, Pl. 11, fig. 25-27.

Description: test free, unilocular, elongate-fusiform, with basal spine and extremely long and slender neck at opposite end, sides nearly parallel over central portion of test; wall calcareous, hyaline, finely perforate, ornamented with numerous very fine longitudinal ribs which die out at beginning of neck; aperture terminal, surrounded by flared lip, at end of long, slender and smooth neck.

Procerolagena wiesneri (Parr, 1950)

Plate 5, figure 9

Lagena striata (Montagu) var. wiesneri PARR, 1950, p. 301.

Procerolagena wiesneri (Parr, 1950). PATTERSON, BURBIDGE and LUTERNAUER, 1998, p. 10, Pl. 5, fig. 5,6.

Description: test free, unilocular, subglobular, broadest near midpoint; wall calcareous, hyaline, surface smooth, finely perforated between costae; on average 28 delicate costae extending from base, every sixth terminates at aperture, 3 intervening costae terminate at base of neck, separated by 2 costae of intermediate length which terminate halfway up to neck; no tendency for costae to form an elongate aboral process; aperture round with a phialine lip.

Genus Pygmaeoseistron Patterson and Richardson, 1988

Pygmaeoseistron hispidulum (Cushman, 1913)

Plate 5, figures $2 \mathrm{a}, \mathrm{b}$ 
Lagena hispidula CUSHMAN, 1913, p. 14, Pl. 5, fig. 2,3.

Pygmaeoseistron hispidulum (Cushman, 1913). PATTERSON and RICHARDSON, 1988, p. 243, 245, fig. 7-10; PATTERSON, BURBIDGE and LUTERNAUER, 1998, p. 10, Pl. 6, fig. 2,3.

Description: test free, unilocular, elongate, circular in section; wall calcareous, translucent, surface coarse, imperforate; aperture small, circular, with phialine lip, terminal on narrow neck.

Family ELLIPSOLAGENIDAE Silvestri, 1923

Subfamily OOLININAE Loeblich and Tappan, 1961

Genus Favulina Patterson and Richardson, 1988

Favulina epibathra Patterson and Richardson, 1988

Plate 6, figures 1a-c

Favulina epibathra PATTERSON and RICHARDSON, 1988, p. 250, fig. 30, 31.

Description: test free, unilocular, subspherical; wall calcareous, hyaline; surface ornamented with 8 to 10 high, stout longitudinal costae, and discontinuous transverse costae, about one-half the height of longidudinal costae, so pattern on test is rectangular; longitudinal costae bifurcate near apex of text to form a single row of hexagonal reticulations; aperture small, round, with phialine lip, may have entosolenian tube.

Favulina melo (d'Orbigny, 1839)

Plate 6, figures 2a, b

Oolina melo D'ORBIGNY, 1839, p. 20, PI. 5, fig. 9; LOEBLICH and TAPPAN, 1953, p. 71, Pl. 12, fig. 8-15; MURRAY, 1971, p. 93, Pl. 37, fig. 4-6. 
Favulina melo (d'Orbigny, 1839). PATTERSON, BURBIDGE and LUTERNAUER, 1998, p. 11, Pl. 6, fig. 6-9.

Description: test free, unilocular, globular, circular in section; wall calcareous, hyaline, fine perforations do not penetrate outer wall; 9 to 14 longitudinal costae extend from base to aperture; numerous downward curved cross struts unite longitudinal costae giving squamiform appearance to test surface; aperture small and circular, phialine lip; entosolenian tube short and straight.

Genus Homalohedra Patterson and Richardson, 1987

Homalohedra apiopleura (Loeblich and Tappan, 1953)

Plate 6, figures 3a-c

Lagena apiopleura LOEBLICH and TAPPAN, 1953, p. 59, P1. 10, fig. 14, 15.

Homalohedra apiopleura (Loeblich and Tappan, 1953). PATTERSON, BURBIDGE and LUTERNAUER, 1998, p. 11, Pl. 28, fig. 4,5.

Description: test free, unilocular, rare twins occur, ovate to pyriform, circular in section, base rounded; wall calcareous, hyaline, finely perforate, translucent; 14 longitudinal costae merge to 7 on upper part of test; collar terminates at base of apertural neck, surface smooth or may have costae with slight bifurcations; aperture small, circular, at end of short smooth neck.

Homalohedra borealis (Loeblich and Tappan, 1954)

Plate 6, figures 4a-c

Oolina costata (Williamson, 1858). LOEBLICH and TAPPAN, 1953, p. 68, Pl. 13, fig. 4-6, new name for Entosolenia costata Williamson, 1858, p. 9, Pl. 1, fig. 18. 
Homalohedra borealis (Loeblich and Tappan, 1954). PATTERSON, BURBIDGE and LUTERNAUER, 1998, p. 11, P1. 7, fig. 1,2.

Description: test free, unilocular, globular, circular in section; wall calcareous, hyaline, finely perforate but pores do not penetrate outer surface; 11 to 17 narrow longitudinal ribs extend from circular basal ring and grade into smooth area surrounding aperture; aperture terminal and circular with slightly produced rim; entosolenian tube short and straight.

\section{Homalohedra guntheri (Earland, 1934)}

Plate 6, figures 5a, b, 6a-c

Lagena guntheri EARLAND, 1934, p. 151, P1. 6, fig. 53, 54.

Homalohedra guntheri (Earland, 1934). PATTERSON, BURBIDGE and LUTERNAUER, 1998, p. 11, Pl. 28, fig. 1,2.

Description: test free, unilocular, pyriform, broadest near midpoint, circular in section; wall calcareous, translucent, imperforate; 6 to 9 longitudinal costae extend from basal ring, then bifurcate and rejoin forming hexagonal pits encircling upper part of test; aperture terminal, small, and round; entosolenian tube short and straight.

$\underline{\text { Remarks: }}$ there is a variation in the number of costae present in this species, going from 9 to 14 .

Subfamily ELLIPSOLAGENINAE Silvestri, 1923

Genus Fissurina Reuss, 1850

Fissurina cucurbitasema Loeblich and Tappan, 1953

Plate 7, figures 3a-c

Fissurina cucurbitasema LOEBLICH and TAPPAN, 1953, p. 76, Pl. 14, fig. 10, 11. 
Description: test free, unilocular, ovate, depressed in cross section, with seed-like outline, occasionally very slightly produced at the base; wall calcareous, translucent, finely perforate, with thin marginal keel, surface smooth; aperture terminal, ovate, with slight lip, entosolenian tube extending about one-half the length of the test.

Fissurina eburnea (Buchner, 1940)

Plate 7, figures 1a, b, 9

Lagena eburnea BUCHNER, 1940, p. 458, Pl. 9, fig. 146, 147.

Fissurina eburnea (Buchner, 1940). PATTERSON, BURBIDGE and LUTERNAUER, 1998, p. 12, Pl. 8, fig. 3,4.

Description: test free, unilocular, compressed, circular in side view; marginal carina completely encircling test; wall calcareous, hyaline, smooth, finely perforate; aperture circular at centre of fissurine opening; entosolenian tube short and straight.

Fissurina lucida (Williamson, 1848)

Plate 7 , figure $2 \mathrm{a}, \mathrm{b}$

Fissurina lucida (Williamson, 1848). LOEBLICH and TAPPAN, 1953, p. 76, Pl. 14, fig. 4; MURRAY, 1971, p. 97, Pl. 39, fig. 1-3; PATTERSON, BURBIDGE and LUTERNAUER, 1998, p. 12, Pl. 8, fig. 5,6.

Description: test free, unilocular, slightly elongated, compressed in section; wall calcareous, hyaline, smooth; broad horseshoe-shaped white band follows the margin except in the upper part of test; test entirely encircled by broad and thick marginal carina; aperture slightly produced, fissurine and very elongate, within marginal carina; entosolenian tube short and straight.

Fissurina quadrata (Williamson, 1858) 
Plate 7, figure 6

Entosolenia marginata (Montagu) var. quadrata WILLIAMSON, 1858, p. 11, P1. 1, fig, 27, 28.

Fissurina quadrata (Williamson, 1858). LOEBLICH and TAPPAN, 1994, p. 90, Pl. 155, fig. 1-6

Description: test free, unilocular, compressed in section, with the shape of a parallelogram; wall calcareous, hyaline, smooth; test encircled by thin marginal carina; aperture slightly produced, fissurine and very elongate, within marginal carina; entosolenian tube short and straight.

Fissurina vitreola (Buchner, 1940)

Lagena vitreola BUCHNER, 1940, p. 477, Pl. 13, fig. 256-258.

Fissurina vitreola (Buchner, 1940). PATTERSON, BURBIDGE and LUTERNAUER, 1998, p. 12, Pl. 9, fig. 1-5.

Description: test free, unilocular, oval in side view, compressed; wall calcareous, hyaline, smooth, fine pores do not penetrate outer wall; 2 while longitudinal bands near margins, may be connected at base forming horseshoe-shaped structure; aperture an elongate fissurine slit on slight extension of test; entosolenian tube short and straight.

Genus Palliolatella Patterson and Richardson, 1987

Palliolatella frangens Buchner, 1940

Plate 7 , figure 4

Lagena frangens BUCHNER, 1940, p. 504, Pl. 19, fig. 407-409. 
Palliolatella frangens (Buchner, 1940). PATTERSON, BURBIDGE and LUTERNAUER, 1998, p. 12, Pl. 10, fig. 3,4.

Description: test free, unilocular, oblong, compressed in cross-section; wall calcareous, hyaline, smooth, finely perforate; wide marginal carina completely encircles test forming a very slight recurved lip around the aperture; 2 high, thin longitudinal costae nearly encircle each test face; aperture a fissurine slit, entosolenian tube attached to one wall and terminating half way down test wall.

\section{Palliolatella immemora Patterson, 1990}

Plate 7, figures 5a-c

Lagena neglecta BUCHNER, 1940, p. 503, Pl. 19, fig. 405 (not Lagena neglecta Buchner, 1940, p. 463, Pl. 11, fig. 173-178).

Palliolatella immemora PATTERSON, 1990, p. 686, fig. 5; PATTERSON, BURBIDGE and LUTERNAUER, 1998, p. 13, Pl. 10, fig. 1,2.

Description: test free, unilocular, compressed, oblong in side view; wall calcareous, hyaline, smooth, finely perforate; thin marginal carina completely encircles test, becomes much wider on short neck; outer margin of carina also thickens on neck, forms recurved area around aperture; aperture small and circular within narrow fissurine slit; entosolenian tube attached to one wall and terminates near test base.

Subfamily PARAFISSURININAE Jones, 1984

Genus Parafissurina Parr, 1947

Parafissurina semicarinata (Buchner, 1940)

Parafissurina lateralis (Cushman) forma semicarinata BUCHNER, 1940, p. 520, Pl. 23, fig. 493-494. 
Parafissurina semicarinata (Buchner, 1940). PATTERSON, BURBIDGE and LUTERNAUER, 1998, p. 13, Pl. 10, fig. 5-8.

Description: test free, unilocular, oblong, compressed in section; wall calcareous, hyaline, smooth, finely perforate; narrow lateral carina encircles test; aperture arched; subterminal slit at one side of test with overhanging hood-like extension of opposite wall; entosolenian tube attached to overhanging wall and terminates halfway down test.

Family GLANDULINIDAE Reuss, 1860

Subfamily GLANDULININAE Reuss, 1860

Genus Laryngosigma Loeblich and Tappan, 1953

Laryngosigma trilocularis (Bagg, 1912)

Plate 7, figures $7 \mathrm{a}, \mathrm{b}$

Polymorphina trilocularis BAGG, 1912, p. 75, Pl. 20, fig. 15-18.

Laryngosigma trilocularis (Bagg, 1912). PATTERSON, BURBIDGE and LUTERNAUER, 1998, p. 13, Pl. 12, fig. 7,8.

Description: test free, elongate, compressed; wall calcareous, hyaline, smooth, finely perforate; chambers 3 to 4 pairs, high, narrow, biserial, added slightly less than $180^{\circ}$ apart, form a sigmoid series; aperture terminal and radiate; entosolenian tube short and straight.

Suborder GLOBIGERININA Delage and Hérouard, 1896

Superfamily GLOBOROTALIACEA Cushman, 1927

Family CANDEINIDAE Cushman, 1927

Subfamily GLOBIGERINITINAE Bermúdez, 1961 
Genus Globigerinita Brönnimann, 1951

Globigerinita uvula (Ehrenberg, 1861)

Plate 15, figures $1 \mathrm{a}, \mathrm{b}$

Pylodexia uvula EHRENBERG, 1861, pp. 276, 277, 308.

Globigerinita uvula (Ehrenberg, 1861). SAITO, THOMPSON and BREGER, 1981, p. 81, Pl. 24.2, fig. 3 .

Description: test free, very small, high trochospiral; 3 or 4 whorls with 15 to 20 chambers, 3 or 4 chambers in last whorl; chambers spherical, increasing slowly in size as added, much embracing; sutures distinct; wall calcareous, fragile, translucent, very smooth, finely perforate, non-spinose, slightly pustulate near aperture; aperture interiomarginal, umbilical, a small, low arch.

Superfamily GLOBIGERINACEA Carpenter, Parker and Jones, 1862 Family GLOBIGERINIDAE Carpenter, Parker and Jones, 1862 Subfamily GLOBIGERININAE Carpenter, Parker and Jones, 1862

Genus Globigerina d'Orbigny, 1826

Globigerina bulloides d'Orbigny, 1826

Plate 15 , figures $2 \mathrm{a}, \mathrm{b}$

Globigerina bulloides D'ORBIGNY, 1826, p. 277; MURRAY, 1971, p. 211, Pl. 87, fig. 1-5; SAITO, THOMPSON and BREGER, 1981, p. 40, PI. 7.1, fig. 1.

Description: test free, size variable, low to medium trochospiral, well lobulate; 2 to two-and-one-half whorls with 8 to 10 chambers, 3 to 5 globular chambers in the last whorl; chambers spherical to slightly ovoid, well separated, size increasing slowly; sutures deep; wall calcareous, uniformly and densely perforated, spines simple and 
with circular cross-sections; aperture umbilical, interiomarginal, a high, symmetrical arch occasionally with thin rim-like lip.

Globigerina quinqueloba Natland, 1938

Plate 15, figures $3 a, b$

Globigerina quinqueloba NATLAND, 1938, p. 149, Pl. 6, fig. 7; MURRAY, 1971, p. 217, Pl. 90, fig. 1-5; SAITO, THOMPSON and BREGER, 1981, p. 48, Pl. 10, fig. 1.

Description: test free, small, low trochospiral; two-and-one-half whorls with 15 chambers, 5 chambers in final whorl; chambers subglobular, slightly flattened radially, final chamber of mature specimens typically partially or completely covers umbilicus like a bulla; sutures distinct, slightly incised; wall calcareous, thick, finely perforated, hispid, spinose; aperture umbilical-extraumbilical, interiomarginal, frequently obscured by final chamber with its rim-like basal lip.

Genus Globigerinoides Cushman, 1927

Globigerinoides cyclostomus (Galloway and Wissler, 1927)

Plate 15, figures $4 \mathrm{a}, \mathrm{b}$

Globigerina cyclostoma GALLOWAY and WISSLER, 1927, p. 42, Pl. 7, fig. 8, 9.

Globigerinoides cyclostomus (Galloway and Wissler, 1927). SAITO, THOMPSON and BREGER, 1981, p. 60, Pl. 15, fig. 2.

Description: test free, small, low to medium trochospiral; 3 whorls with 11 chambers, 3 chambers on final whorl; chambers subspherical to ovoid, increasing moderately in size but closely packed giving the test a rectangular outline; wall calcareous, coarsely perforated, spinose; spines simple rounded cross sections, in simple raised bases; 
primary aperture umbilical, small oval opening, secondary aperture(s) on spiral side at intersection of spiral and intercameral sutures.

Suborder ROTALIINA Delage and Hérouard, 1896

Superfamily BOLIVINACEA Glaessner, 1937

Family BOLIVINIDAE Glaessner, 1937

Genus Bolivina d'Orbigny, 1839

Bolivina decussata Brady, 1881

Plate 8, figures $1 \mathrm{a}, \mathrm{b}$

Bulimina (Bolivina) decussata BRADY, 1881, p. 58, fig. in Brady, 1884, p. 423, Pl. 53, fig. $12,13$.

Bolivina decussata Brady, 1881. PATTERSON, BURBIDGE and LUTERNAUER, 1998, p. 14, Pl. 11, fig. 5,6.

Description: test free, elongate, very compressed, of nearly equal thickness throughout; wall calcareous, translucent, finely perforate although perforations commonly obscured by coarse reticulations formed by secondary calcification; chambers 8 to 10 pairs, rapidly expand from subacute initial end; sutures distinct, slightly curved at about $45^{\circ}$ to longitudinal axis; aperture loop shaped at top of final formed chamber, with internal toothplate attached to one side.

Bolivina minuta Natland, 1938

Plate 8 , figures $2 \mathrm{a}, \mathrm{b}$

Bolivina minuta NATLAND, 1938, p. 146, Pl. 5, fig. 10.

Description: test free, very compressed, sides nearly parallel, periphery angled, flattened, forming a slightly concave side; wall calcareous, thin, finely perforated; 8 
to 10 pairs of chambers biserially arranged, rapidly increasing in size; sutures distinct, curved, quite oblique; aperture a loop-shaped opening in top of last chamber. Genus Bolivinellina Saidova, 1975 Bolivinellina pacifica (Cushman and McCulloch, 1942)

Plate 8 , figures $4 \mathrm{a}, \mathrm{b}$

Bolivina acerosa Cushman var. pacifica CUSHMAN and MCCULLOCH, 1942, p. 185, Pl. 21, fig. 2, 3 .

Bolivinellina pacifica (Cushman and McCulloch, 1942). PATTERSON, BURBIDGE and LUTERNAUER, 1998, p. 14, Pl. 13, fig. 1,2.

Description: test free, elongate, compressed, broadest near aperture and tapers to base; wall calcareous, hyaline, smooth, finely perforate; chambers 10 to 13 pairs, biserially arranged, slightly inflated and wider than high, gradually increase in size as added; sutures slightly curved and depressed, about $60^{\circ}$ to longitudinal axis; aperture lipped, loop-shaped at base of final formed chamber, with internal toothplate attached to one side.

Superfamily CASSIDULINACEA d'Orbigny, 1939

Family CASSIDULINIDAE d'Orbigny, 1939

Subfamily CASSIDULININAE d'Orbigny, 1939

Genus Cassidulina d'Orbigny, 1826

Cassidulina crassa d'Orbigny, 1839

Plate 8, figures 6a-d

Cassidulina crassa D'ORBIGNY, 1839, p. 56, P1. 7, fig. 18-20. 
Cassidulina crassa d'Orbigny, 1839. ALVES MARTINS and RUIVO DRAGÃO

GOMES, 2004, p. 118, fig. 2.67.

Description: test free, circular to oval, biconvex; periphery slightly rounded; chambers slightly inflated, last chamber rectangular to trapezoidal; sutures slightly depressed; wall calcareous, delicate, translucent, shiny, finely perforated; aperture a simple slit in the middle of a central, triangular depression of the basal suture of the last chamber, partially closed by an apertural plate.

Remarks: C. crassa differs from C. reniforme Nørvang in the more globular test, slightly inflated chambers and depressed sutures.

Genus Islandiella Nørvang, 1959

Islandiella helenae Feyling-Hanssen and Buzas, 1976

Plate 8, figures 5a-c

Islandiella helenae FEYLING-HANSSEN and BUZAS, 1976, p. 155, fig. 1-4; PATTERSON, BURBIDGE and LUTERNAUER, 1998, p. 15, Pl. 31, fig. 1-3.

Description: test free, biconvex with a sub acutely thickened peripheral margin, lenticular; wall calcareous, perforate, translucent to hyaline, very distinctly radial when viewed in polarized light; about 5 pairs of chambers in the final whorl, biserially arranged, evolutely coiled so that the previous whorls are seen through the thick, clear shell material of the umbilical region, chambers felly bean-shaped, oriented at $45^{\circ}$ to umbilicus giving them the appearance of leaning into side of previous chamber; sutures distinct, thickened, flush with the surface, outlining the chambers; aperture a broad short slit paralleling the periphery and with a free apertural tongue projecting out of it. 
Superfamily TURRILINACEA Cushman, 1927

Family STAINFORTHIDAE Reiss, 1963

Genus Stainforthia Hofker, 1956

Stainforthia feylingi Knudsen and Seidenkrantz, 1994

Plate 8, figures $3 a-c$

Stainforthia feylingi KNUDSEN and SEIDENKRANTZ, 1994, P1. 1, fig. 1-32; Pl. 2, fig. 1-6, 8; PATTERSON, BURBIDGE and LUTERNAUER, 1998, p. 16, P1. 14, fig. 5,6 .

Description: test free, elongate, streamlined, fusiform, compressed and ovate in crosssection, broadest often near the middle; wall calcareous, hyaline, smooth, finely perforate; chambers slightly inflated, approximately 7 to 11 pairs, triserially arranged in early stages, later biserial and often slightly twisted; sutures depressed and slightly curved at $45^{\circ}$ to $50^{\circ}$ to longitudinal axis; aperture depressed and loop-shaped at base of final chamber, with narrow incurved lip at one side and broad toothplate at opposite side bending under lip and partially closing opening; toothplate with serrated free folded portion, lower portion attached to preceding chamber wall.

Superfamily BULIMINACEA Jones, 1875

Family BULIMINIDAE Jones, 1875

Genus Protoglobulimina Hofker, 1951

Protoglobulimina pupoides (d'Orbigny, 1846)

Plate 9, figures 1a-c

Bulimina pupoides D’ORBIGNY, 1846, p. 185, Pl. 11, fig. 11, 12. 
Protoglobulimina pupoides (d'Orbigny, 1846). PATTERSON, BURBIDGE and LUTERNAUER, 1998, p. 17, Pl. 17, fig. 7,8.

Description: test free, elongate, broadest near base, almost circular in cross-section; wall calcareous, hyaline, smooth, finely perforate; chambers inflated, much higher than wide and strongly overlapping, triserially arranged, in 2 or 3 whorls; sutures depressed; aperture elongate, extends up from base of final chamber; successive chambers connected by an internal toothplate; toothplate final tip can be seen in aperture.

Family BULIMINELLA Cushman, 1911

Genus Buliminella Cushman, 1911

Buliminella elegantissima (d'Orbigny, 1839)

Plate 9, figures 2a-d

Bulimina elegantissima D'ORBIGNY, 1839, p. 51, Pl. 7, fig. 13, 14.

Buliminella elegantissima (d'Orbigny, 1839). MURRAY, 1971, p. 105, Pl. 42, fig. 14; PATTERSON, BURBIDGE and LUTERNAUER, 1998, p. 17, Pl. 16, fig. 6,7.

Description: test free, elongate, with a high and close spiral formed by numerous high narrow chambers in 3 to 4 whorls; wall calcareous, hyaline, smooth, finely perforate; aperture loop-shaped with internal toothplate connecting aperture with foramen of previous chamber.

Subfamily UVIGERININAE Haeckel, 1894

Genus Euuvigerina Thalmann, 1952

Euuvigerina aculeata (d'Orbigny, 1846)

Plate 9, figures 3a-c 
Uvigerina aculeata D'ORBIGNY, 1846, p. 191, Pl. 11, fig. 27, 28.

Euuvigerina aculeata (d'Orbigny, 1846). PATTERSON, BURBIDGE and LUTERNAUER, 1998, p. 17, Pl. 16, fig. 1-3.

Description: test free, elongated, rounded in section; wall calcareous, hyaline, surface finely perforate and covered with numerous cone-shaped spines occasionally uniting to form discontinuous rib-like elements; 4 to 5 whorls of inflated, triserially arranged chambers become cuneate in later whorls; aperture small and circular within a phialine lip at top of tubular neck; toothplate a narrow twisted ribbon extending from the aperture to fasten against the previous foramen.

Euuvigerina peregrina (Cushman, 1923)

Plate 9, figures 5a-d

Uvigerina peregrina CUSHMAN, 1923, p. 166, Pl. 42, fig. 7-10; MURRAY, 1971, p. 121, Pl. 50, fig. 1-7;

Euuvigerina peregrina (Cushman, 1923). ALVES MARTINS and RUIVO DRAGÃO GOMES, 2004, p. 162, fig. 2.93, 2.94.

Description: test free, elongate, triserial to biserial in last chambers; chambers numerous, distinct, inflated; sutures depressed; wall calcareous, perforate, surface with numerous longitudinal costae, generally discontinous, disrupted by sutures; space between costae presents little pustules; aperture terminal, rounded, on tubular neck, bordered with phialine lip, narrow ribbon like and twisted toothplate extends within from aperture to fasten against previous foramen.

Genus Neouvigerina Thalmann, 1952

Neouvigerina cf. proboscidea (Schwager, 1866) 
Uvigerina proboscidea SCHWAGER, 1866, p. 250, Pl. 7, fig. 96.

Neouvigerina proboscidea (Schwager, 1866). NARAYAN, BARNES and JOHNS, 2005, p. 137, Pl. 5., fig. 20, 21.

Description: test small to medium, stout, one-and-one-and-a-half times as long as wide; 3 to 4 whorls; chambers in early portion triserially arranged, small, closely packed, later portion biserial, much inflated, globular; periphery lobulate; sutures distinct, depressed; wall calcareous, finely perforate, ornamented with numerous fine papillae, appearing slightly spinose or granular; aperture terminal, rounded, at end of elongate, papilliose neck with phialine lip.

Remarks: the ornamentation in these specimens is much damaged, making it difficult to ascribe them with certainty to this species. However, the overall shape and fainted papillae seem to belong to $N$. proboscidea.

Subfamily ANGULOGERININAE Galloway, 1933

Genus Angulogerina Cushman, 1927

Angulogerina fluens Todd, 1947

Plate 9, figures $4 \mathrm{a}, \mathrm{b}$

Angulogerina fluens TODD, 1947, in CUSHMAN and MCCULLOCH, 1948, p. 288, Pl. 36, fig. 1; LOEBLICH and TAPPAN, 1953, p. 112, Pl. 20, fig. 10-12; PATTERSON, BURBIDGE and LUTERNAUER, 1998, p. 18, Pl. 16, fig. 4,5.

Description: test free, elongate, trigonal in cross-section, angles subrounded and carinate; wall calcareous, hyaline, smooth except numerous discontinuous longitudinal costae cross suture lines and extend from base to aperture; chambers arranged in 4 to 5 whorls, initially triserial, become cuneate; sutures depressed and 
curved; aperture terminal, reniform, produced on very short neck and bordered by pronounced lip; internal toothplate extends from foramen to foramen, externally visible as narrow projection in aperture.

Superfamily DISCORBACEA Ehrenberg, 1838

Family ROSALINIDAE Reiss, 1963

Genus Gavelinopsis Hofker, 1951

Gavelinopsis campanulata (Galloway and Wissler, 1927)

Plate 10, figures 1a-c

Globorotalia campanulata GALLOWAY and WISSLER, 1927, p. 58, Pl. 9, fig. 14.

Gavelinopsis campanulata (Galloway and Wissler, 1927). PATTERSON, BURBIDGE and LUTERNAUER, 1998, p. 18, Pl. 18, fig. 5-7.

Description: test free, plano-convex; wall calcareous, hyaline, smooth; all chambers visible on convex spiral side, only final 6 to 7 of final whorl visible on ventral side; sutures smooth and radiating on spiral side, depressed and slightly curved on ventral side, radiating from open umbilicus with central umbilical plug, often invisible, partially filling gap; aperture an interiomarginal extra umbilical arch with secondary sutural openings at margins of previous chambers.

Genus Rosalina d'Orbigny, 1926

Rosalina columbiensis (Cushman, 1925)

Plate 10, figures $2 \mathrm{a}-\mathrm{c}$

Discorbis columbiensis CUSHMAN, 1925, p. 43, Pl. 6, fig. 13.

Rosalina columbiensis (Cushman, 1925). PATTERSON, BURBIDGE and LUTERNAUER, 1998, p. 18, Pl. 19, fig. 1-3. 
Description: test free or attached, plano-convex, trochospiral; wall calcareous, hyaline, smooth, finely perforate; chambers irregular in shape and gradually increase in size as added, all visible on spiral side, and only 6 to 7 visible on final whorl around open umbilicus on partially evolute umbilical side; sutures depressed and slightly curved; aperture an interiomarginal arch at base of final chamber, near periphery on umbilical side extending into umbilicus; planktic-stage specimens have large subglobular float chamber completely covering umbilical side.

Superfamily DISCORBINELLACEA Sigal, 1952

Family PSEUDOPARRELLIDAE Voloshinova, 1952

Subfamily PSEUDOPARRELLINAE Voloshinova, 1952

Genus Epistominella Husezima and Maruhasi, 1944

Epistominella vitrea Parker, 1953

Plate 10, figures 3a-c

Epistominella vitrea PARKER, 1953, in PARKER, PHLEGER and PEIRSON, 1953, p. 9, Pl. 4, fig. 34-36, 40, 41; MURRAY, 1971, p. 131 Pl. 54, fig. 1-6; PATTERSON, BURBIDGE and LUTERNAUER, 1998, p. 19, Pl. 20, fig. 3-5.

Description: test free, trochospiral, biconvex, periphery rounded, and slightly lobulate; wall calcareous, hyaline, smooth, finely perforate; test spiral side with all 3 whorls and chambers visible and sutures straight, depressed, and oblique; only final 6 chambers visible on umbilical side with sutures radial and depressed; aperture narrow lipped slit oriented slightly oblique to peripheral margin.

Superfamily PLANORBULINACEA Schwager, 1877

Family CIBICIDIDAE Cushman, 1927 
Subfamily CIBICIDINAE Cushman, 1927

Genus Lobatula Fleming, 1828

Lobatula fletcheri (Galloway and Wissler, 1927)

Plate 10, figures 4a-c

Cibicides fletcheri GALLOWAY and WISSLER, 1927, p. 64, Pl. 10, fig. 8, 9.

Lobatula fletcheri (Galloway and Wissler, 1927). PATTERSON, BURBIDGE and LUTERNAUER, 1998, p. 19, P1. 19, fig. 4-6.

Description: test free, plano-convex, trochospiral with spiral side flattened and umbilical side rounded and convex; wall calcareous, translucent, smooth, coarsely perforate on spiral side; 8 to 9 slightly inflated chambers visible on concave umbilical side; all chambers visible on spiral side with a well developed umbilical boss; sutures slightly curved and depressed; aperture low interiomarginal lipped, may extend along spiral suture on spiral side.

Lobatula lobatula (Walker and Jacob, 1784)

Plate 10, figures 5a-d

Nautilus lobatulus WALKER and JACOB, 1784, p. 20, Pl. 3, fig. 71.

Cibicides lobatulus (Walker and Jacob, 1784). MURRAY, 1971, p. 175, Pl. 73, fig. 17.

Lobatula lobatula (Walker and Jacob, 1784). LOEBLICH and TAPPAN, 1987, p. 168, Pl. 637, fig. 10-13; VILLANUEVA GUIMERANS and CERVERA CURRADO, 1999, p. 186, fig. 2.3; ALVES MARTINS and RUIVO DRAGÃO GOMES, 2004, p. 211, fig. 2.126 . 
Description: test trochospiral, ovate; wall calcareous, coarsely perforate or lacking pores on umbilical side, on spiral side with pores of intermediate size and uniformly distributed; spiral side flat or irregular, umbilical side convex; chambers inflated, 7 or 8 in final whorl, gradually increasing in size as added; periphery acute, carinate; sutures on spiral side slightly raised and imperforate, depressed and slightly backwards on umbilical side; aperture interiomarginal, extraumbilical-equatorial, bordered by protruding rim continuing into spiral supplementary aperture, open in last 1 to 3 chambers.

\section{Lobatula mckannai (Galloway and Wissler, 1927)}

Plate 11, figures 1a-c

Cibicides mckannai GALLOWAY and WISSLER, 1927, p. 65, P1. 10, fig. 5-6.

Lobatula mckannai (Galloway and Wissler, 1927). PATTERSON and KUMAR, 2002, p. 121, Pl. 1, fig. 5; PATTERSON, BURBIDGE and LUTERNAUER, 1998, p. 19, Pl. 19, fig. 7-9.

Description: test free, plano-convex, trochospiral with flattened spiral side and high convex umbilical side; wall calcareous, translucent, coarsely perforate, especially on umbilical side where has roughened appearance; only final 9 slightly inflated chambers of umbilical side visible; all chambers visible on spiral side; sutures slightly depressed and radiate; aperture low interiomarginal lipped slit which may extend back several chambers on spiral side.

Subfamily STICHOCIBICIDINAE Saidova, 1981

Genus Dyocibicides Cushman and Valentine, 1930

Dyocibicides biserialis Cushman and Valentine, 1930 
Plate 11, figures $2 \mathrm{a}, \mathrm{b}$

Dyocibicides biserialis CUSHMAN and VALENTINE, 1930, p. 31, Pl. 10, fig. 1,2; PATTERSON, BURBIDGE and LUTERNAUER, 1998, p. 20, Pl. 20, fig. 1,2.

Description: test attached, elongate, trochospiral, with attachment area on spiral side; wall calcareous, translucent, smooth, coarsely perforate; all chambers visible on flattened spiral side; only 7 to 8 slightly inflated chambers visible in final whorl of umbilical side, gradually increasing in size as added; later chambers uncoiled and irregularly biserial, increasing greatly in size as added; sutures depressed and curved; aperture terminal and lipped.

Superfamily NONIONACEA Schultze, 1854

Family NONIONIDAE Schultze, 1854

Subfamily NONIONINAE Schultze, 1854

Genus Nonionella Cushman, 1926

Nonionella digitata Nørvang, 1945

Plate 11, figure 5

Nonionella turgida (Williamson) var. digitata NØRVANG, 1945, p. 29, fig. 4.

Nonionella digitata Nørvang, 1945. PATTERSON, BURBIDGE and LUTERNAUER, 1998, p. 20, Pl. 21, fig. 1-3.

Description: test free, compressed, general outline elongate, elliptical, in low trochospiral coil, periphery rounded; wall calcareous, hyaline, smooth, finely perforate without pustules; spiral side partially evolute around umbonal boss with all chambers visible (about 10), rapidly increasing in size; sutures strongly depressed and slightly curved; umbilical side involute with only 5 to 6 chambers of final whorl 
visible, flap-like extensions of final chambers subdivided in finger-like projections that cross umbilical regions, obscuring it; aperture small interiomarginal and nearly equatorial arch, extending onto umbilical side.

Nonionella stella Cushman and Moyer, 1930

Plate 11, figures 3a-c

Nonionella miocenica Cushman var. stella CUSHMAN and MOYER, 1930, p. 56, Pl. 7, fig. 17 .

Nonionella stella Cushman and Moyer, 1930. PATTERSON, BURBIDGE and LUTERNAUER, 1998, p. 20, Pl. 22, fig. 1-3.

Description: test free, trochospiral, slightly compressed; wall calcareous, translucent, smooth, finely perforate; 7 to 10 inflated low chambers rapidly increase in size as added; large umbilical flap extends from last chamber and covers umbilical region; all chambers visible on spiral side; aperture low arch extending somewhat onto umbilical side, at base of large flat apertural face.

Nonionella cf. turgida (Williamson, 1858)

Plate 11, figure 4

Rotalina turgida WILLIAMSON, 1858, p. 50, P1. 9, fig. 95-97.

Nonionella turgida (Williamson, 1858). MURRAY, 1971, p. 193, Pl. 81, fig. 1-5.

Nonionella cf. N. turgida (Williamson, 1858). PATTERSON, BURBIDGE and LUTERNAUER, 1998, p. 20, Pl. 23, fig. 8.

Description: test free, compressed, slightly elongated in low trochospiral coil, periphery rounded; all chambers visible on spiral side, partially evolute around umbonate boss; only 9 final chambers visible on umbilical side, extension of final 
chambers into umbilicus, partially obscuring it; sutures depressed and slightly curved on both sides; wall calcareous, hyaline, smooth, finely perforate; aperture low, interiomarginal, a nearly equatorial arch, extending slightly onto umbilical side.

$\underline{\text { Remarks: }}$ the few specimens recovered were broken in the last chamber, therefore the species is named $N$. cf. turgida.

Genus Nonionellina Voloshinova, 1958

Nonionellina labradorica (Dawson, 1860)

Plate 11, figures $7 \mathrm{a}-\mathrm{c}$

Nonionica scapha var. labradorica DAWSON, 1860, p. 191, fig. 4.

Nonion labradoricum (Dawson, 1860). LOEBLICH and TAPPAN, 1953, p. 86, Pl. 17, fig. 1,2 .

Nonionellina labradorica (Dawson, 1860). PATTERSON, BURBIDGE and LUTERNAUER, 1998, p. 20, P1. 23, fig. 1,2.

Description: test free, trochospiral in early stage, later nearly planispiral and involute, periphery rounded and slightly lobulate; wall calcareous, hyaline, smooth other than fine pustules clustered in sutural depression and filling umbilicus, finely perforate; 14 chambers visible on both umbilical and spiral sides; sutures strongly depressed and curved; aperture low arched slit at base of final chamber.

Genus Pseudononion Asano, 1936

Pseudononion basispinata (Cushman and Moyer, 1930)

Plate 11 , figures $6 a, b$

Nonion pizarrensis Berry var. basispinata CUSHMAN and MOYER, 1930, p. 54, Pl. 7, fig. 18 . 
Pseudononion basispinata (Cushman and Moyer, 1930). PATTERSON, BURBIDGE and LUTERNAUER, 1998, p. 21, Pl. 23, fig. 3-5.

Description: test free, asymmetric planispiral and involute, compressed; wall calcareous, hyaline, smooth, finely perforate; 10 to 16 slightly inflated low chambers rapidly increasing in size as added; sutures slightly depressed and curved, hispid material found in open umbilicus and along lower parts of sutures on one side, or with an umbilical knob on the other side; aperture narrow, interiomarginal with equatorial opening.

Subfamily ASTRONONIONINAE Saidova, 1981

Genus Astrononion Cushman, 1937

Astrononion gallowayi Loeblich and Tappan, 1953

Plate 12, figures 1a-c

Astrononion gallowayi LOEBLICH and TAPPAN, 1953, p. 90, Pl. 17, fig. 4-7; PATTERSON, BURBIDGE and LUTERNAUER, 1998, p. 21, Pl. 23, fig. 6-7.

Description: test free, planispiral and involute, compressed, periphery rounded and lobulate; wall calcareous, hyaline, with medium sized perforations; 7 to 8 strongly inflated chambers of final whorl visible, increase gradually in size as added; wedgeshaped supplementary chambers surround umbilicus on each side, taper outward to suture about two-thirds the distance to periphery; sutures slightly curved and depressed; aperture low arch at base of final chamber extending on each side toward umbilicus with supplementary opening at outer posterior margin or each of the supplementary chambers.

Family TRICHOHYALIDAE Saidova, 1981 
Genus Buccella Andersen, 1952

Buccella depressa Andersen, 1952

Plate 12, figures $2 \mathrm{a}, \mathrm{b}$

Buccella depressa ANDERSEN, 1952, p. 145, 146, fig. 7, 8; PATTERSON, BURBIDGE and LUTERNAUER, 1998, p. 22, Pl. 24 fig. 1-3.

Description: test free, trochospiral, roughly biconvex, periphery rounded, lobulate; wall calcareous, hyaline, smooth except concentrations of fine pustules in umbilicus and in narrow bands along sutures, coarsely perforate; two-and-one-half whorls and all chambers visible on slightly convex spiral side; spiral side sutures slightly curved, oblique, and very slightly depressed; only highly inflated final 7 to 9 chambers of final whorl visible on umbilical side and gradually increase in size as added; umbilical side sutures slightly curved and radial; aperture interiomarginal with slitlike supplementary apertures found along posterior margins of chambers on umbilical side.

Buccella frigida (Cushman, 1922)

Plate 12, figures 3a-c

Pulvinulina frigida CUSHMAN, 1922, p. 144; LOEBLICH and TAPPAN, 1953, p. 115, Pl. 22, fig. 2, 3; MURRAY, 1971, p. 129, Pl. 53, fig. 1-5; REINHARDT, EASTON and PATTERSON, 1996, p. 41, fig. 3; PATTERSON, BURBIDGE and LUTERNAUER, 1998, p. 22, Pl. 25 fig. 6-8.

Description: test free, trochospiral, plano-convex; wall calcareous, hyaline, smooth, finely perforate; all chambers visible on convex, spiral side; only 6 to 7 slightly inflated chambers gradually increase in size as added and visible on flattened 
umbilical side; sutures oblique on spiral side, slightly curved and radial and depressed on umbilical side; pustulose material most concentrated on the umbilicus partially obscures sutures; aperture interiomarginal with supplementary sutural apertures at posterior margin or each chamber.

Buccella hannai (Phleger and Parker, 1951), emend. Andersen, 1952

Plate 12, figures $4 a-c$

Eponides hannai PHLEGER and PARKER, 1951, p. 21, Pl. 10, fig. 11-14.

Buccella hannai (Phleger and Parker, 1951). ANDERSEN, 1952, p. 147, fig. 3

Description: test free, trochospiral, biconvex, ranging from specimens with equal convexity on both sides to extremely convex on dorsal side and flat on ventral side; wall calcareous, hyaline, smooth, finely perforate; 7 to 9 chambers, slightly inflated; three to three-and-one-half whorls; sutures curved, limbate on spiral side, depressed and radial on umbilical side; periphery distinctly lobulate, typically acute and limbate; pustulose material most concentrated on the umbilicus partially obscures sutures; aperture interiomarginal with supplementary sutural apertures at posterior margin or each chamber.

Buccella inusitata Andersen, 1952

Plate 12, figures 5a, b

Buccella inusitata ANDERSEN, 1952, p. 148, fig. 10a-c, 11a-c; LOEBLICH and TAPPAN, 1953, p. 116, Pl. 22, fig. 1.

Description: test free, trochospiral, dorsal and ventral sides equally biconvex in the microspheric form, ventral side nearly flat and dorsal side extremely convex in the megalospheric form; wall calcareous, hyaline, smooth, finely perforated; all chambers 
visible on convex, spiral side; only 7 to 9 slightly inflated chambers visible on flattened umbilical side; sutures slightly limbate, strongly oblique to the peripheral margin on dorsal side, depresses and radial on ventral side; umbilicus, sutures and basal margin of last chamber with thick coating of pustules; periphery acute and limbate, last 2 or 3 chambers usually lobate; sutural apertures at posterior margin or each chamber.

Buccella tenerrima (Bandy, 1950)

Plate 12, figures $6 a-c$

Rotalia tenerrima BANDY, 1950, p. 278, Pl. 42, fig. 3.

Buccella tenerrima (Bandy, 1950). REINHARDT, EASTON and PATTERSON, 1996, p. 41 , fig. 3 .

Description: test free, trochospiral, biconvex; wall calcareous, hyaline, smooth, finely perforated; periphery slightly lobulate, carinate; umbilicus pustulose; three-and-onehalf whorls, 8 to 10 chambers in last whorl; dorsal sutures somewhat oblique and slightly curved, ventral sutures depressed, nearly radial; pustulose material covering umbilicus and sutures; aperture a series of pores at base of last septal face.

Superfamily ROTALIACEA Ehrenberg, 1839

Family ELPHIDIIDAE Galloway, 1933

Subfamily ELPHIDIINAE Galloway, 1933

Genus Cribroelphidium Cushman and Brönnimann, 1948

Cribroelphidium excavatum (Terquem, 1876)

Plate 13, figures 1-5

Polystomella excavata TERQUEM, 1876, p. 25, Pl. 2, fig. 2. 
Elphidium excavatum (Terquem, 1876). MURRAY, 1971, p. 159, Pl. 66, fig. 1-7.

Cribroelphidium excavatum (Terquem, 1876). PATTERSON, BURBIDGE and LUTERNAUER, 1998, p. 22, Pl. 25, fig. 4,5; P1. 26, fig. 1,2.

Description: test free, planispiral, involute, biumbonate, periphery rounded; wall calcareous, thin, smooth except concentrations of pustules found along sutures, in umbilicus, and around aperture; fine circular pores less concentrated along septa and on apertural face; no pores in central extensions of chamber walls; usually 9 to 11 gradually enlarging chambers in last whorl; sutures depressed, backward-curved, usually closed before reaching the umbilical region, with single row of large sutural pores, and few 2 to 7 short sutural bridges which may not be visible in smaller specimens; aperture multiple interiomarginal.

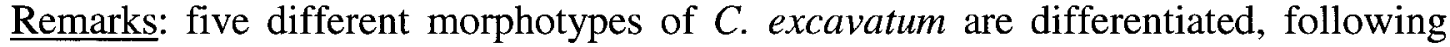
the work of Miller et al., (1982). They are grouped on five formae: C. excavatum forma excavata (Terquem, 1876), C. excavatum forma selseyensis (Heron-Allen and Earland, 1911), C. excavatum forma clavata (Cushman, 1930), C. excavatum forma lidoensis (Cushman, 1936), and C. excavatum forma magna (Miller et al., 1982). For more information on the taxonomy and ecology of these formae, the reader is referred to Miller et al., 1982.

Cribroelphidium foraminosum (Cushman, 1927)

Plate 14, figures 1a-c

Elphidium hughesi var. foraminosum CUSHMAN, 1939, p. 49, Pl. 13, fig. 8. 
Cribroelphidium foraminosum (Cushman, 1927). REINHARDT, EASTON and PATTERSON, 1996, p. 41, fig. 3; PATTERSON, BURBIDGE and LUTERNAUER, 1998, p. 22, Pl. 24, fig. 6-8.

Description: test free, planispiral, involute, biumbonate, periphery rounded; wall calcareous, hyaline, smooth, coarsely perforate except on imperforate apertural face; 10 to 11 chambers of last whorl visible and gradually increase in size as added; sutures depressed, backward-curved, with single row of large oblong sutural pores separated by short sutural bridges; aperture multiple interiomarginal.

Cribroelphidium hallandense (Brotzen, 1943)

Plate 14, figures 3a-c

Elphidium hallandense BROTZEN, 1943, p. 268, fig. 109.

Cribroelphidium hallandense (Brotzen, 1943). PATTERSON, BURBIDGE and LUTERNAUER, 1998, p. 22, Pl. 25, fig. 1-3.

Description: test free, planispiral, involute, sides flat, periphery broadly rounded, slightly lobulate margin; wall calcareous, hyaline, smooth except bands of granular material found in umbilicus along sutures and near aperture; 7 to 9 slightly inflated and gradually enlarging chambers in final whorl; sutures slightly depressed and curved; aperture a low interiomarginal equatorial arch often obscured by granular material covering apertural face.

Cribroelphidium magellanicum (Heron-Allen and Earland, 1932)

Plate 14, figures $4 \mathrm{a}-\mathrm{c}$

Elphidium (Polystomella) magellanicum HERON-ALLEN and EARLAND, 1932, p. 440, Pl. 16, fig. 26-28. 
Elphidium magellanicum (Heron-Allen and Earland, 1932). MURRAY, 1971, p.

163, Pl. 68, fig. 1-7; MURRAY, 2003, p. 21, fig. 7.9, 7.10.

Description: test free, planispiral, involute, biumbonate, compressed; 5 to 6 chambers in the last whorl; sutures backward curved and strongly depressed, chambers slightly inflated; periphery rounded, markedly lobulate; sutures filled with very finely granular matter, contrasting with glassy chambers; fossettes concealed under granules; aperture a series of interiomarginal pores.

Cribroelphidium microgranulosum (Galloway and Wissler, 1927)

Plate 14, figures 2a-c

Themeon decipiens GALLOWAY and WISSLER, 1927, p. 83, Pl. 12, fig. 15,16.

Cribroelphidium microgranulosum (Galloway and Wissler, 1927). PATTERSON, BRUNNER, CAPO and DAHL, 1990, p. 11, fig. 13; REINHARDT, EASTON and PATTERSON, 1996, p. 41, fig. 3.

Description: test free, planispiral, involute, biumbonate, compressed; 5 to 6 chambers in the last whorl; periphery very slightly lobulate; sutures slightly curved, slightly depressed and each provided with 8 to 10 small, indistinct, round pores; wall calcareous, granular, completely covered with pustulose material; aperture a very narrow curved slit.

Genus Elphidiella Cushman, 1936

Elphidiella hannai (Cushman and Grant, 1927)

Plate 14, figures 5a-c

Elphidium hannai CUSHMAN and GRANT, 1927, p. 77, Pl. 7, fig. 1 
Elphidiella hannai (Cushman and Grant, 1927). REINHARDT, EASTON and PATTERSON, 1996, p. 41, fig. 3; PATTERSON, BURBIDGE and LUTERNAUER, 1998, p. 22, Pl. 26, fig. 3,4.

Description: test free, lenticular, planispiral, involute, bilaterally symmetrical, periphery rounded; wall calcareous, hyaline, smooth except concentration of granular material near aperture; 13 to 15 chambers of the last whorl visible and increase gradually in size as added; sutures distinct, thickened but not raised, slightly curved, bordered by double row of fine sutural pores that extend to smooth umbilical region; aperture a row of pores at base of apertural face of final formed chamber.

Subphylum SARCODINA Schmarda, 1871

Class RHIZOPODEA von Siebold, 1845

Subclass LOBOSA Carpenter, 1861

Order ARCELLINIDA Kent, 1880

Superfamily ARCELLACEA Ehrenberg, 1830

Family CENTROPYXIDIDAE Deflandre, 1953

Genus Centropyxis Stein, 1859

Centropyxis aculeata (Ehrenberg, 1832)

Strain 'aculeata' Reinhardt, Dalby, Kumar and Patterson, 1998

Arcella aculeata EHRENBERG, 1832, p. 91.

Centropyxis aculeata (Ehrenberg, 1832). MEDIOLI and SCOTT, 1983, p. 39, fig. 11.7-11.16, Pl. 7, fig. 10-12, 18, 19.

Centropyxis aculeata (Ehrenberg, 1832) strain aculeata REINHARDT, DALBY, KUMAR and PATTERSON, 1998, Pl. 1, fig. 1. 
Description: test depressed; in dorsal view, usually large and more or less circular; anterior slope large, with small $\left(15^{\circ}\right.$ to $\left.45^{\circ}\right)$ anterior angle; posterior slope ill-defined, practically absent, fusing into fundus; fundus quite posterior; 1 to 8 spines in posterolateral margin; wall basically organic, agglutinated, with siliceous particles completely covering the membrane; aperture subcentral, usually slightly anterior, invaginated.

Centropyxis constricta (Ehrenberg, 1843)

Strain 'constricta' Reinhardt, Dalby, Kumar and Patterson, 1998

Plate 15, figure 9

Arcella constricta EHRENBERG, 1843, p. 410, Pl. 4, fig. 35, Pl. 5, fig. 1.

Centropyxis constricta (Ehrenberg, 1843). MEDIOLI and SCOTT, 1983, p. 41, fig. $12.7,12.14,12.16,12.17$, Pl. 7 , fig. 1-4, 6-9.

Centropyxis constricta (Ehrenberg, 1843) strain constricta REINHARDT, DALBY, KUMAR and PATTERSON, 1998, Pl. 1, fig. 4.

Description: test much less depressed than in C. aculeata, usually elliptical on dorsal view, with profile usually raised posteriorly; large $\left(40^{\circ}\right.$ to $\left.65^{\circ}\right)$ anterior angle; posterior angle well-defined; fundus raised in uppermost position; ventral side often small; 3 or less spines on fundus; wall agglutinated, completely covered with mineral particles of various nature; aperture antero-marginal, with variable degree of invagination.

Centropyxis constricta (Ehrenberg, 1843)

Strain 'aerophila' Reinhardt, Dalby, Kumar and Patterson, 1998

Plate 15, figure 5 
Centropyxis aerophila DEFLANDRE, 1929.

Centropyxis aerophila Deflandre, 1929. OGDEN and HEDLEY 1980, p. 48-49.

Centropyxis constricta (Ehrenberg, 1843). MEDIOLI and SCOTT, 1983, p. 41, fig. 12.6, 12.8-12.12, 12.15, 12.18-12.26, Pl. 7, fig. 5 .

Cucurbitella [sic.] constricta REINHARDT, DALBY, KUMAR and PATTERSON 1998, Pl. 1, fig. 6.

Centropyxis constricta (Ehrenberg, 1843) strain aerophila KUMAR and DALBY, 1998, fig. 5.1.

Description: test much less depressed than in $C$. aculeata, usually elliptical on dorsal view, with profile usually raised posteriorly; large $\left(40^{\circ}\right.$ to $\left.65^{\circ}\right)$ anterior angle; posterior angle well-defined; fundus raised in uppermost position; ventral side often small; spines absent; wall agglutinated, completely covered with mineral particles of various nature; aperture antero-marginal, with variable degree of invagination.

Genus Cyclopyxis Deflandre, 1929

Cyclopyxis kahli (Deflandre, 1929)

Plate 15 , figure 10

Centropyxis kahli DEFLANDRE, 1929, p. 330

Cyclopyxis kahli (Deflandre, 1920). OGDEN and HEDLEY, 1980, p. 70-71, pl. 24, figs. a-e; ROE and PATTERSON, 2006, p. 29, Pl. 1, fig. 7, p. 33, Pl. 3, fig. 1-6.

Description: test plano-convex, radially symmetrical, hemispherical; wall agglutinated; aperture circular, large, centered.

Family HYALOSPHENIIDAE Schulze, 1877

Genus Heleopera Leidy, 1879 
Heleopera sphagni (Leidy, 1874)

Plate 15 , figures $11 \mathrm{a}, \mathrm{b}$

Difflugia sphagni LEIDY, 1874, p. 157

Heleopera picta LEIDY, 1879.

Heleopera sphagni (Leidy, 1879). MEDIOLI and SCOTT, 1983, p. 37-38, fig. 9, Pl. 6, figs. 15-18.

Description: test strongly compressed, ovoid; oral pole narrower in broadside view; test composed of siliceous idiosomes, substituted more or less extensively by xenosomes; aperture at narrow end of test, an elongated, narrow ellipse with acute commissures.

Genus Nebela (Leidy, 1874)

Nebela collaris (Ehrenberg, 1848)

Nebela collaris EHRENBERG, 1848; OGDEN and HEDLEY 1980, p. 94-95; KUMAR and DALBY, 1998, fig. 9.2.

Description: test strongly compressed, ovoid; oral pole narrower in broadside view; test composed of siliceous plates; collar showing at narrow end of test; aperture elongate, narrow, at end of collar.

Family DIFFLUGIDAE Stein, 1859

Genus Difflugia Leclerc in Lamarck, 1816

Difflugia oblonga Ehrenberg, 1832

Plate 15, figure 6 
Difflugia oblonga EHRENBERG, 1832, p. 90; OGDEN and HEDLEY, 1980, p.

148, pl. 63, figs. a-c; HAMAN, 1982, p. 397, Pl. 3, Figs. 19-25; SCOTT and MEDIOLI, 1983, p. 818, fig. 6, P1. 2, fig. 1-17.

Description: test variable in shape and size, pyriform, flask-shaped, rounded in crosssection; fundus rounded to subacute; neck subcylindrical, more or less long, gradually narrowed toward oral end; test agglutinated, made of sand particles, sometimes mixed with diatom frustules; aperture terminal, circular to slightly oval.

Difflugia protaeiformis Lamarck, 1816

Plate 15 , figure 7

Difflugia protaeiformis LAMARCK, 1816, p. 95; KUMAR and DALBY, 1998, fig. $14.1,15.1,15.2$.

Description: test pyriform, flask shaped, rounded in cross-section; fundus tapering, acuminate with one or more spines; oral end sometimes narrower; test agglutinated, fine to coarse grains; aperture terminal, circular.

Difflugia urceolata Carter, 1864

Plate 15, figure 8

Difflugia urceolata CARTER, 1864, p. 27, Pl. 1, fig. 7; MEDIOLI and SCOTT, 1983, p. 31, fig. 1-23, Pl. 4, fig. 1-4; KUMAR and DALBY, 1998, fig. 22.1, 22.2.

Description: test spheroid to acutely ovate, amphora-like to cauldron-like; fundus rounded to acuminate; neck short, terminating in evaginated, sometimes recurved or straight collar of variable shape and size; wall agglutinated, composed of sand grains of variable coarseness; aperture wide, circular, terminal.

Genus Lagenodifflugia Medioli and Scott, 1983 
Lagenodifflugia vas (Leidy, 1874)

Difflugia vas LEIDY, 1874, p. 155.

Lagenodifflugia vas (Leidy, 1874). MEDIOLI and SCOTT 1983, p. 33, Pl. 2, figs. 1823, 27, 28; REINHARDT, DALBY, KUMAR and PATTERSON 1998, Pl. 1, fig. 8.

Description: main part of test usually ovoid, with neck arising form its narrower extremity; wide fundus; neck usually slightly higher than wide, coniform, truncated at aperture and constriction; constriction between body and neck not always conspicuous, normally visible in wet specimens; wall agglutinated; aperture rounded, terminal.

\section{Plates}

The following plates 1 to 15 illustrate most of the foraminiferal and thecamoebian species found within the SBIC with scanning electron photomicrographs obtained using a JEOL 6400 Scanning Electron Microscope at the Carleton University Research Facility for Electron Microscopy (CURFEM). These digital images were converted into plates using Adobe (C) Photoshop 7.0 and Adobe $(\subset)$ Illustrator 11 for Mac OS X. 
Plate 1:

1.- Ammodiscus gullmarensis Höglund, from sample FC04-86, side view. 2.Cribrostomoides crassimargo (Norman), from sample FC04-90, side view showing lobulate periphery and coarse agglutination. 3.- Cribrostomoides sp. A, from sample FC04-77; 3a, side view, showing rounded periphery and inflated last chamber; $3 \mathrm{~b}$, apertural view, showing inflated last chamber. 4.- Cribrostomoides jeffreysii (Williamson), from sample BE5; 4a, side view, showing ovate periphery; 4b, apertural view, showing depressed test and typical aperture; $4 \mathrm{c}$, apertural view from another specimen from sample BE7, showing leaf-like aperture. 5.- Cribrostomoides cf. subglobosum (Cushman), from sample ALS2; 5a, side view showing rounded periphery; $5 b$, apertural view showing globular test and characteristic aperture. 6.Haplophragmoides bradyi (Brady), from sample BE3; 6a, side view showing very smooth test; $6 \mathrm{~b}$, apertural view showing characteristic interiomarginal aperture; $6 \mathrm{c}$, side view of a more evolute specimen from sample BE5. 7.- Recurvoides turbinatus (Brady), from sample ALS1; 7a, side view; 7b, apertural view showing asymmetry of test and angled aperture. All scales are $10 \mu \mathrm{m}$ unless otherwise indicated. 

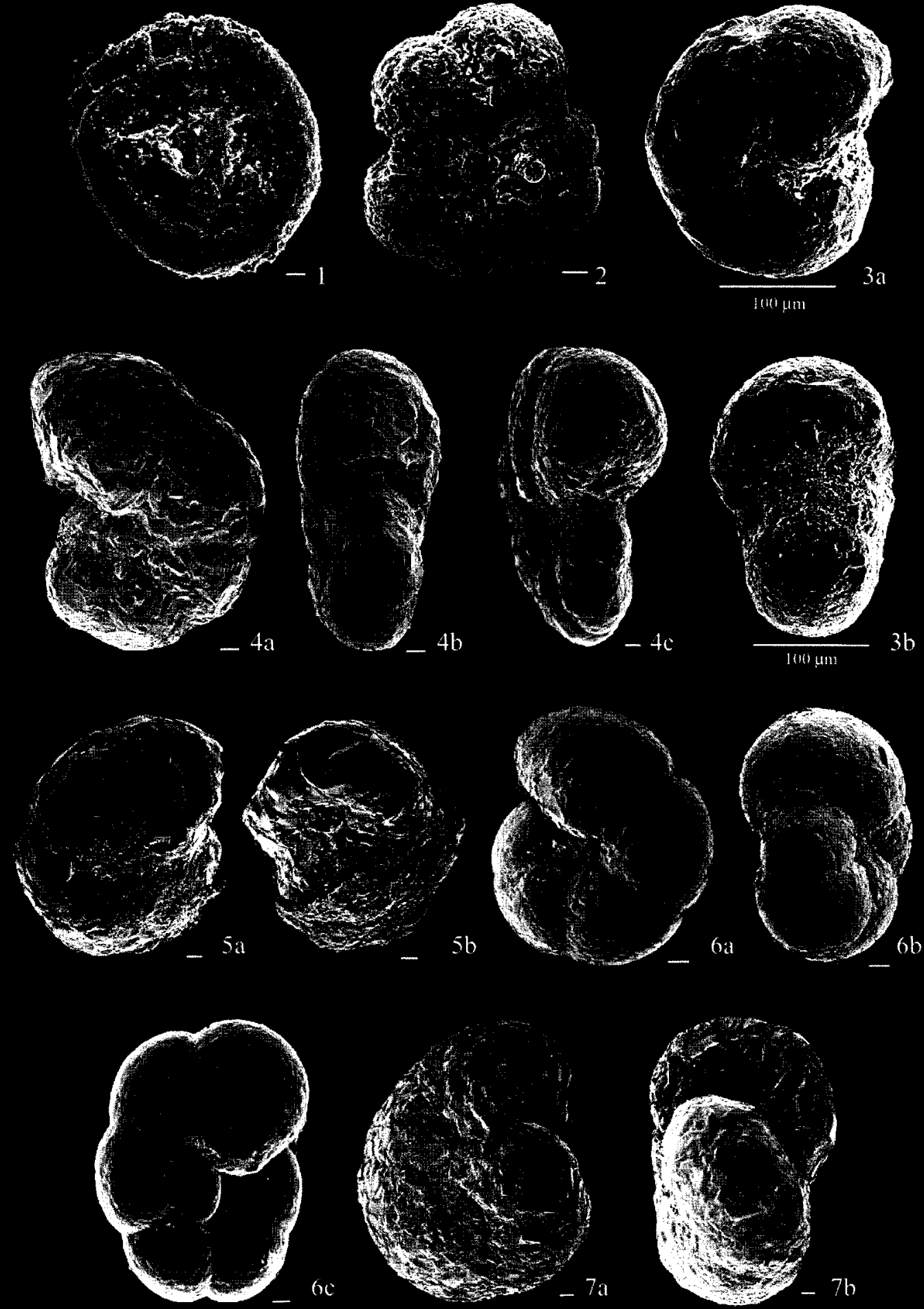
Plate 2:

1.- Cribrostomoides wiesneri (Parr); 1a, side view of specimen from sample FC04-99; 1b, side view of another specimen from sample FC04-99; 1c, apertural view of a third specimen from sample FC04-99. 2.- Trochammina inflata (Montagu), from sample BE3; 2a, dorsal view; 2b, umbilical view. 3.- Portatrochammina bipolaris Brönnimann and Whitaker, from sample BE7; 3a, dorsal view; 3b, umbilical view, showing characteristic umbilical flap; $3 c$, side view from another specimen from sample BE7. 4.- Trochammina charlottensis Cushman, from sample BE5; 4a, dorsal view; 4b, umbilical view, showing characteristic very inflated last chamber; 4c, side view, from another specimen from sample ALS3, with first chamber broken. 5.Trochammina nana (Brady), from sample FC04-77; 5a, dorsal view; 5b, umbilical view, showing very deep umbilicus. 6.- Trochammina discorbis Earland, from sample BE5; 6a, dorsal view; $6 \mathrm{~b}$, umbilical view; $6 \mathrm{c}$, side view showing very high spiral. All scales are $10 \mu \mathrm{m}$ unless otherwise indicated. 


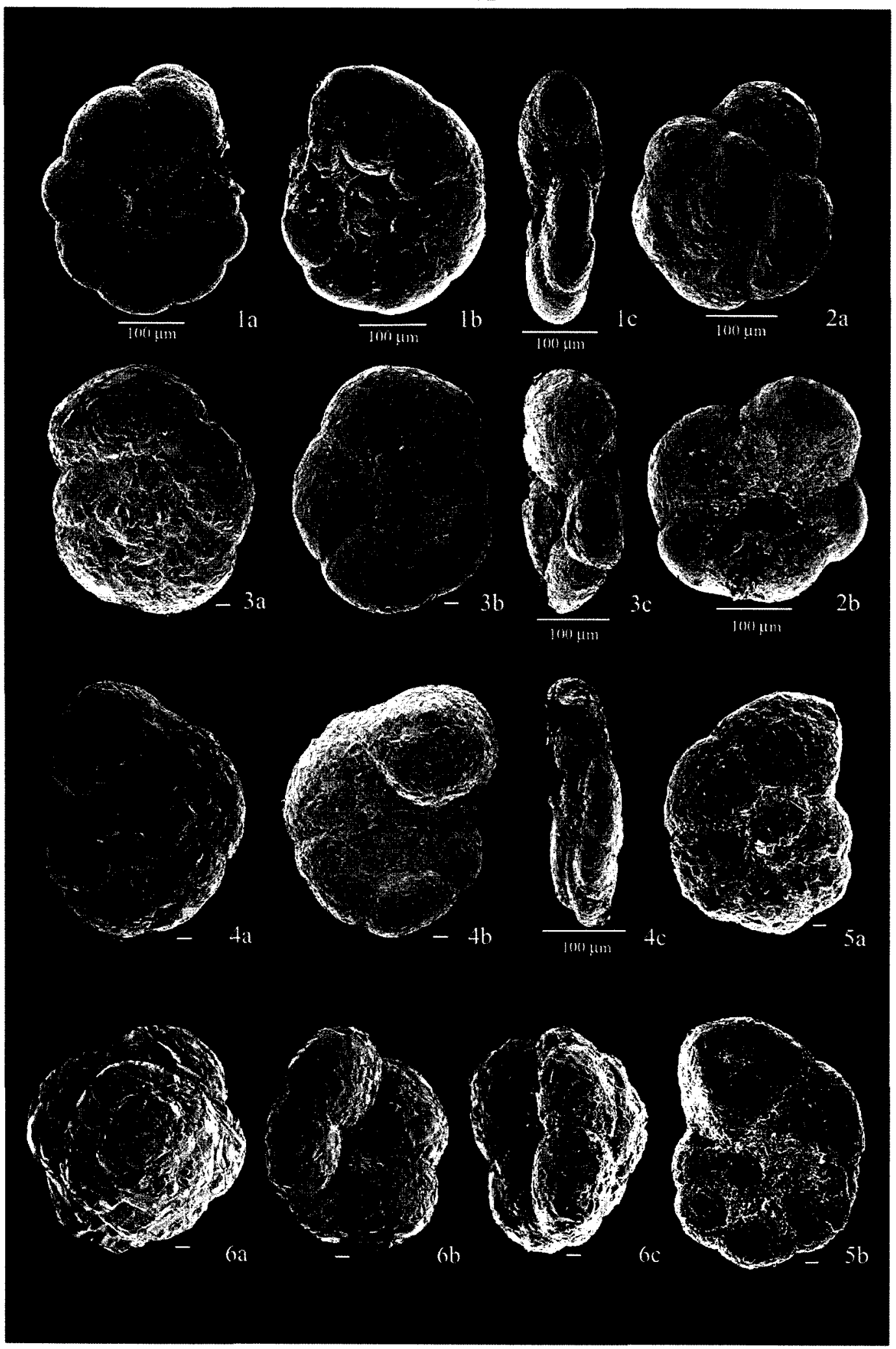


Plate 3:

1.- Trochammina nitida Brady, from sample BE7; 1a, dorsal view, showing very straight sutures; $1 \mathrm{~b}$, umbilical view. 2.- Trochammina squamata Jones and Parker, from sample FC04-96; 2a, dorsal view; 2b, umbilical view. 3.- Trochammina ochracea (Williamson), from sample ALS1; 3a, dorsal view; 3b, umbilical view, with umbilical region filled with organic matter; $3 c$, side view, showing depressed concave test. 4.- Two forms of $T$. discorbis attached to each other, from sample FC04-79. 5.Trochammina pacifica Cushman, from sample BE5; 5a, dorsal view; 5b, umbilical view, showing inflated chambers; $5 c$, side view, showing aperture reaching the umbilicus; 5d, detail of aperture showing lip. 6.- Trochammina rotaliformis HeronAllen and Earland, both specimens from sample BE1; 6a, dorsal view; 6b, umbilical view, with debris partially obscuring star-shaped umbilicus. 7.- Trochammina cf. globigeriniformis (Parker and Jones) from sample BE5; 7a, dorsal view of specimen with last chamber broken; $7 \mathrm{~b}$, umbilical view of another specimen. All scales are 10 $\mu \mathrm{m}$ unless otherwise indicated. 


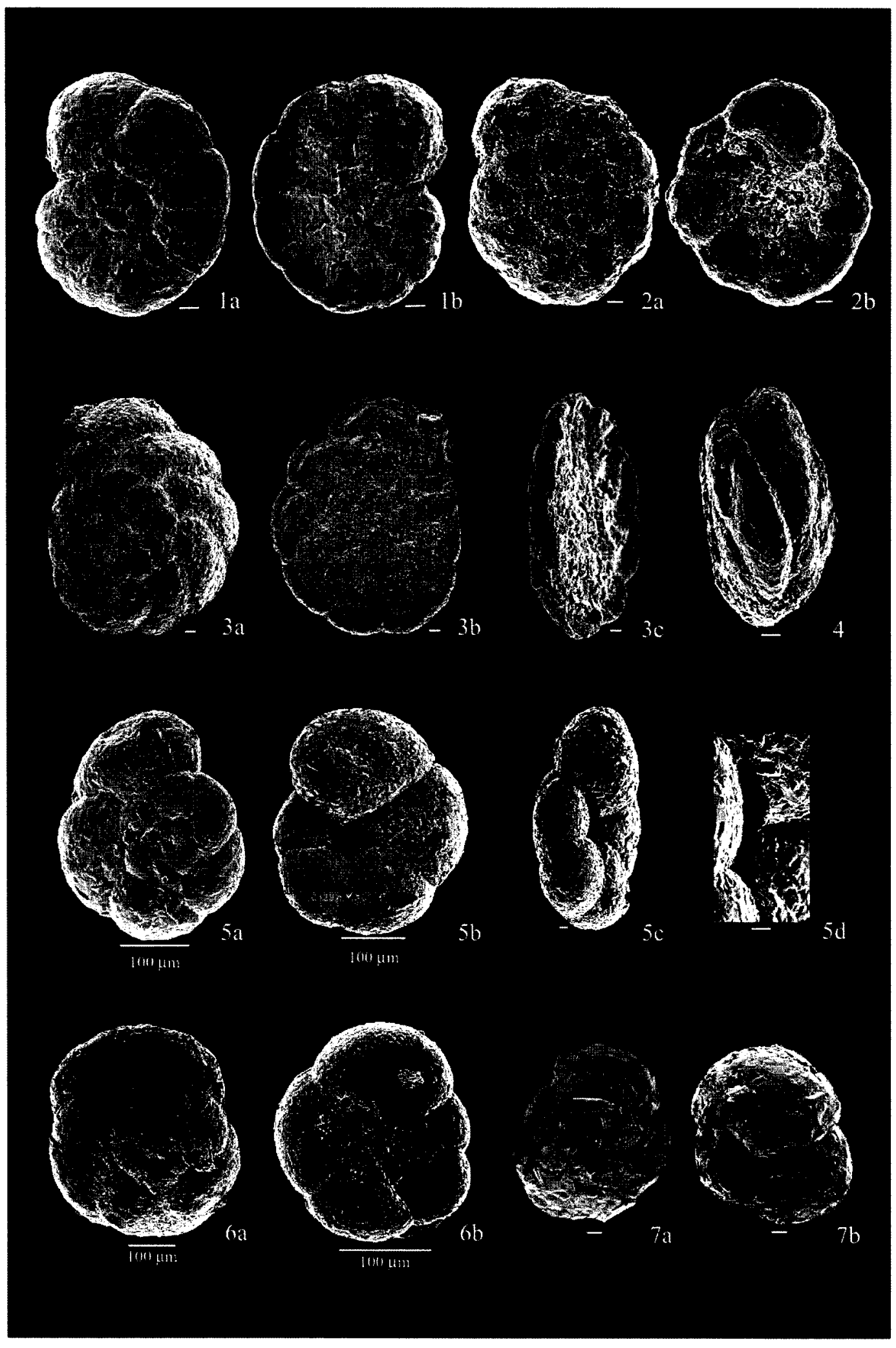


Plate 4:

1.- Gaudryina arenaria Galloway and Wissler, from sample BE1, side view of eroded specimen. 2.- Textularia earlandi Parker, from sample BE7; 2a, side view of broken specimen, with first chambers missing; $2 b$, apertural view, showing interiomarginal arch. 3.- Reophax catella Höglund, from sample FC04-121, side view. 4.- Eggerella advena Cushman, from sample ALS3; 4a, side view; 4b, apertural view; $4 c$, side view of second specimen, from sample ALS3; 4d, apertural view of specimen 4c. 5.- Eggerella belizensis, n. sp., from sample ALS2; 5a, side view; 5b, apertural view; $5 c$, side view of a second specimen from sample ALS3; 5d, apertural view of specimen 5d. 6.- Spiroplectammina biformis (Parker and Jones), from sample ALS1; $6 a$, side view of long specimen; $6 \mathrm{~b}$, side view of shorter specimen from sample BE1; $6 c$, apertural view of specimen $6 b$. 


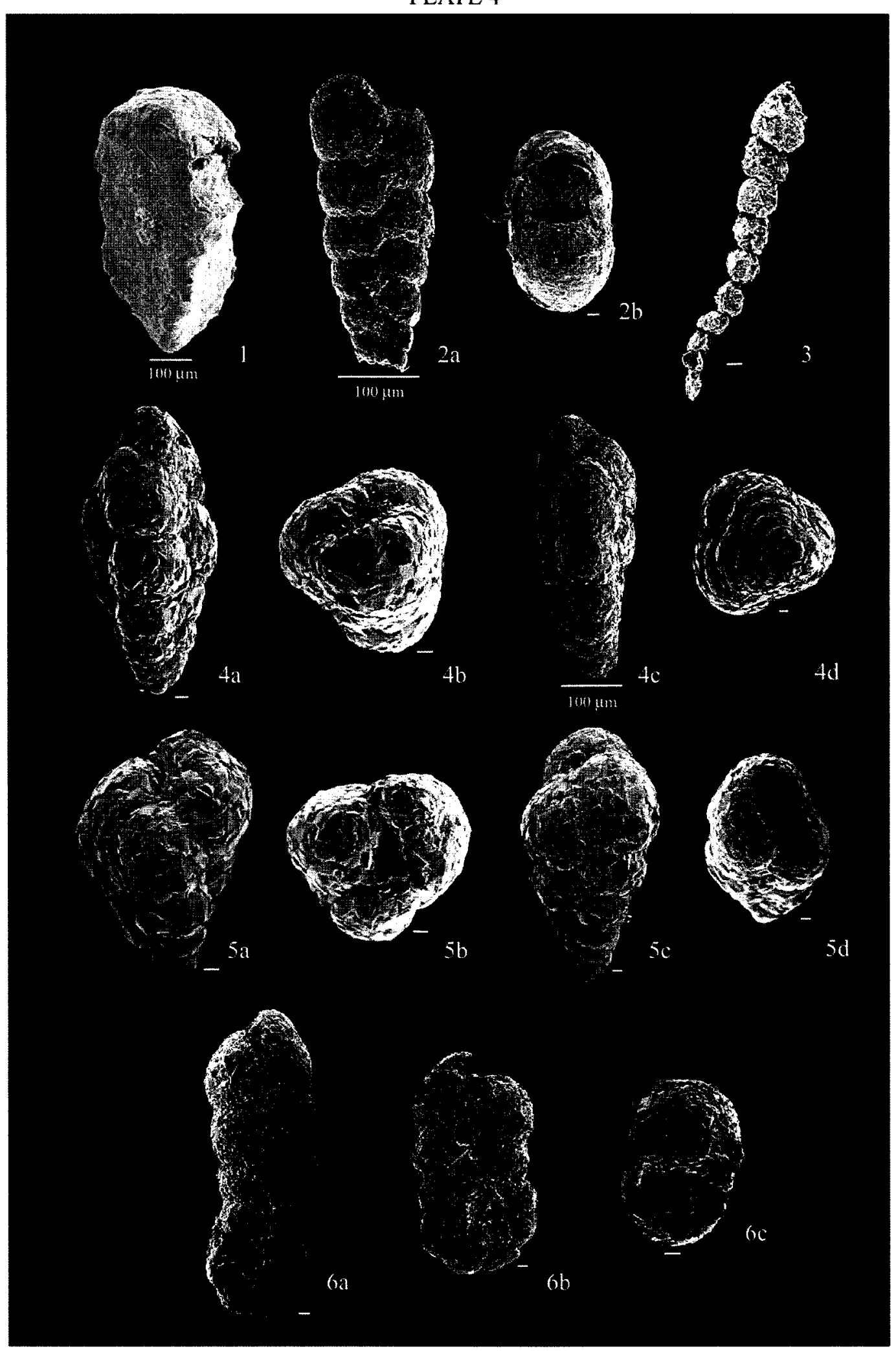


Plate 5:

1.- Dentalina ittai Loeblich and Tappan, from sample BE1; $1 \mathrm{a}$, side view; 1b, detail of apertural end. 2.- Pygmaeoseistron hispidulum (Cushman), from sample BE3; 2a, side view of very corroded specimen; 2 b, apertural view. 3.- Lagena laevis (Montagu), from sample BE2; 3a, side view; 3b, apertural view. 4.- Lagena meridionalis Wiesner, from sample FC04-68; 4a, side view of well preserved specimen; $4 b$, side view of very corroded specimen. 5.- Lagena semilineata Wright, from sample BE1; 5a, side view; 5b, bottom view, showing hollow basal spine. 6.Procerolagena mollis Cushman, from sample FC04-66, side view. 7.- Procerolagena gracilis (Williamson), from sample FC04-75, side view; 8.- Procerolagena cf. amphora (Reuss), from sample $\mathrm{BE} 1 ; 8 \mathrm{a}$, side view; 8b, apertural view. 9.Procerolagena wiesneri (Parr), from sample BE1, side view. 10.- Hyalinonetrion dentaliforme (Bagg), from sample $\mathrm{BE} 1$; side view. All scales are $10 \mu \mathrm{m}$ unless otherwise indicated. 


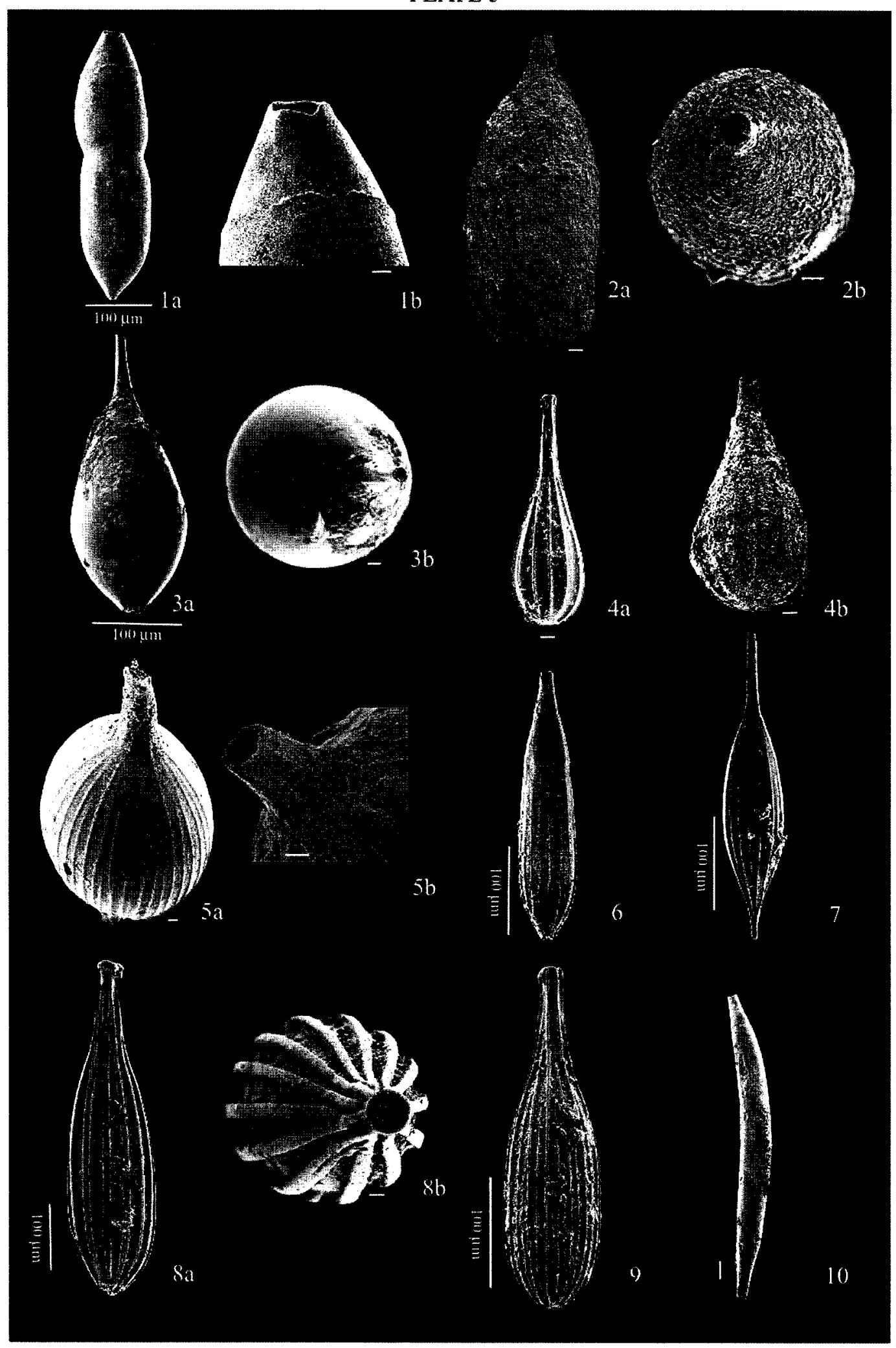


Plate 6:

1.- Favulina epibathra Patterson and Richardson, from sample $\mathrm{BE} 1 ; 1 \mathrm{a}$, side view; 1b, apertural view; 1c, bottom view. 2.- Favulina melo (d'Orbigny), from sample BE2; 2a, side view; 2b, apertural view. 3.- Homalohedra apiopleura (Loeblich and Tappan), from sample BE1; 3a, side view; 3b, apertural view; 3c, bottom view. 4.- Homalohedra borealis (Loeblich and Tappan), from sample BE1; 4a, side view; $4 \mathrm{~b}$, apertural view; $4 \mathrm{c}$, bottom view. 5-6.- Homalohedra guntheri (Earland), from sample BE1; 5a, side view of specimen showing few longitudinal costae; $5 \mathrm{~b}$, apertural view of specimen $5 \mathrm{a} ; 6 \mathrm{a}$, side view of specimen from sample FC04-38 showing more longitudinal costae; 6b, apertural view of specimen $6 a ; 6 c$, bottom view of specimen $6 \mathrm{a}$. All scales are $10 \mu \mathrm{m}$ unless otherwise indicated. 
PLATE 6

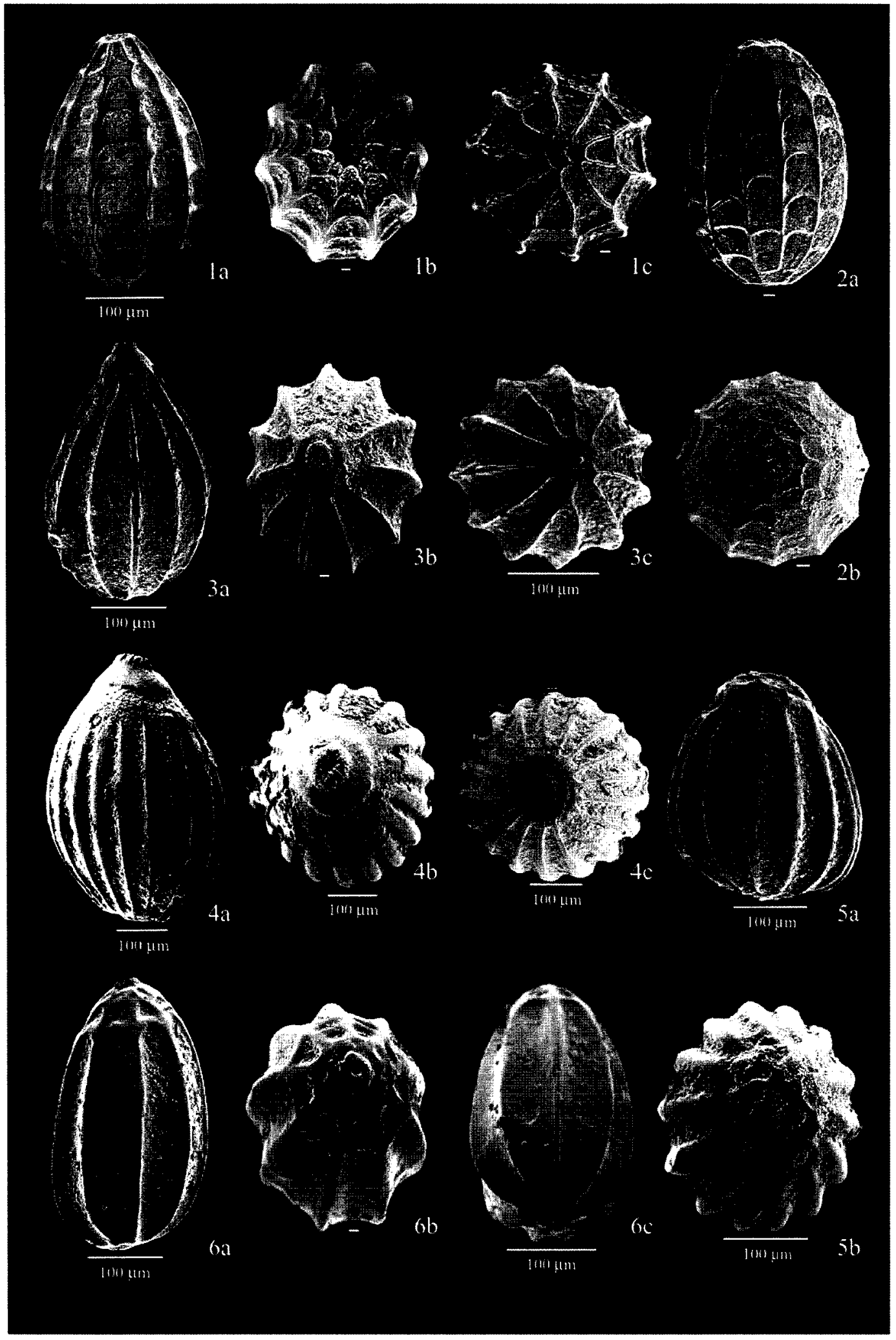


Plate 7:

1.- Fissurina eburnea (Buchner), from sample BE1; 1a, side view; 1b, lateral view showing aperture. 2.- Fissurina lucida (Williamson), from sample FC04-59; 2a, side view; 2b, apertural view. 3.- Fissurina cucurbitasema Loeblich and Tappan; 3a, side view of specimen from sample FC04-65, showing thin marginal keel; $3 b$, apertural view of specimen from sample FC04-67; 3c, side view of specimen from sample FC04-76, showing seed-like shape. 4.- Palliolatella frangens (Buchner), side view of specimen from sample BE1. 5.- Palliolatella immemora Patterson, from sample BE1; 5a, side view; 5b, apertural view; 5c, detail of the aperture. 6.- Fissurina quadrata Williamson, from sample BE1, side view. 7.- Laryngosigma trilocularis (Bagg), pictures of two specimens from sample BE1; 7a, side view; 7b, apertural view showing radiate aperture. 8.- Fissurina eburnea (Buchner), from sample BE1, apertural view of specimen with more globular test. All scales are $10 \mu \mathrm{m}$ unless otherwise indicated. 


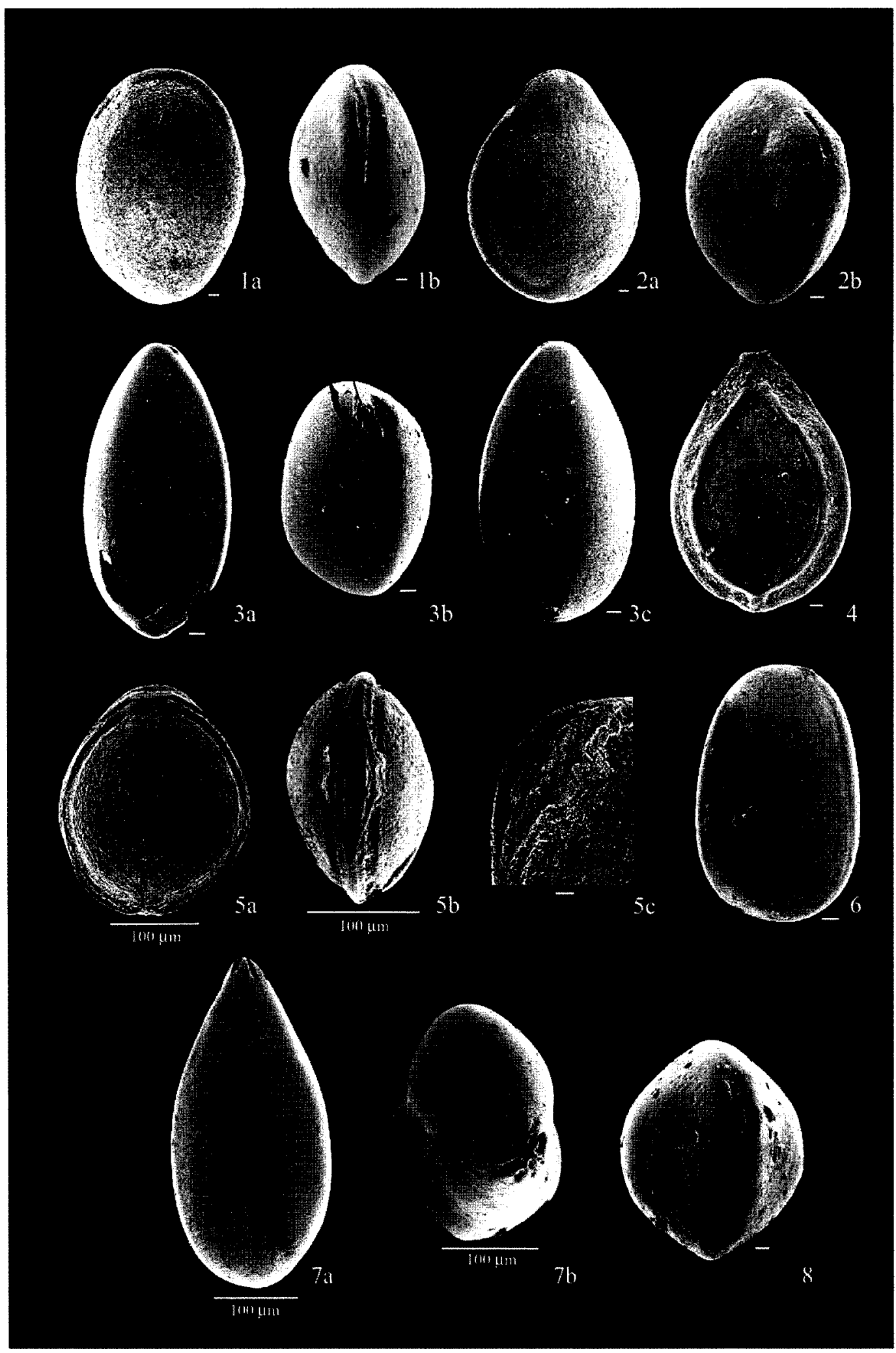


Plate 8:

1.- Bolivina decussata Brady, from sample BE1; 1a, side view showing roughened surface; 1b, apertural view. 2.- Bolivina minuta Natland, from sample $\mathrm{BE} 1 ; 2 \mathrm{a}$, side view showing nearly parallel sides; $2 \mathrm{~b}$, apertural view. 3.- Stainforthia feylingi Knudsen and Seidenkrantz, from sample BE1; 3a, side view showing smooth, finely perforated test; $3 \mathrm{~b}$, side view showing fusiform test; $3 \mathrm{c}$, detail of aperture showing toothplate. 4.- Bolivinellina pacifica (Cushman and McCulloch), from sample $\mathrm{BE} 1 ; 4 \mathrm{a}$, side view showing elongated test and biserial arrangement; $4 \mathrm{~b}$, apertural view, showing lip and internal toothplate. 5.- Islandiella helenae FeylingHanssen and Buzas, from sample BE1; 5a, side view showing smooth test; $5 \mathrm{~b}$, view of the other side, showing position of aperture along periphery; $5 \mathrm{c}$, apertural view showing biconvex test. 6.- Cassidulina crassa d'Orbigny, from sample FC04-14; 6a, side view showing rectangular last chamber; $6 \mathrm{~b}$, view of the other side, showing slightly inflated chambers; $6 \mathrm{c}$, detail of aperture; $6 \mathrm{~d}$, view of another specimen from sample BE3, showing rounded outline and depressed sutures, different from the more compressed test and flushed sutures of $C$. reniforme. All scales are $10 \mu \mathrm{m}$ unless otherwise indicated. 


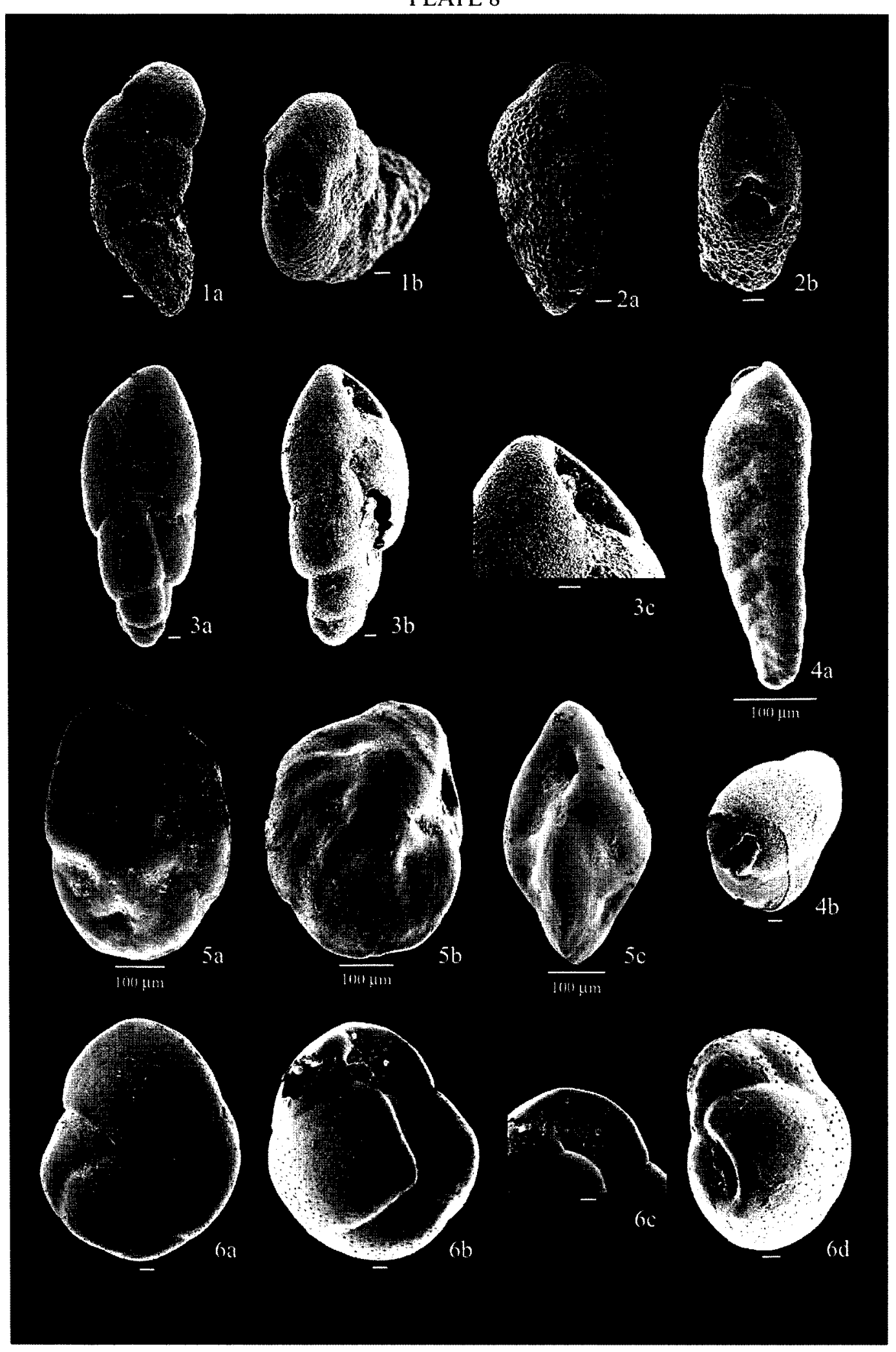


Plate 9:

1.- Protoglobulimina pupoides (d'Orbigny), three specimens from sample FC04-76; 1a, side view showing strongly overlapping chambers; $1 \mathrm{~b}$, apertural view showing internal toothplate; 1c, basal view showing circular cross-section and triserial arrangement. 2.- Buliminella elegantissima (d'Orbigny); 2a, side view of specimen from sample BE1, showing close spiral; 2b, side view of specimen from sample FC04-64, showing aperture obscured by debris; 2c, apertural view of specimen from sample FC04-63, showing internal toothplate; 2 d, detail of aperture of specimen 2c. 3.- Euuvigerina aculeata (d'Orbigny), from sample FC04-52; 3a, side view showing elongated shape; $3 \mathrm{~b}$, side view showing etched surface, spines uniting to form ribs at the base of test can be discerned; $3 \mathrm{c}$, detail of tubular neck, showing remnants of cone-shaped spines at the base. 4.- Angulogerina fluens Todd, from sample BE1; 4a, side view showing elongate test and longitudinal costae crossing the sutures; 4b, apertural view showing trigonal cross-section. 5.- Euuvigerina peregrina (Cushman); 5a, side view of specimen from sample FC04-53 showing clear longitudinal costae; $5 \mathrm{~b}$, apertural view of specimen $5 \mathrm{a}$ showing rounded aperture on top of tubular neck; $5 c$, side view of specimen from sample FC04-55, showing etched surface; 5d, side view of specimen from sample FC04-52 showing less developed costae and well developed pustules between them. All scales are $100 \mu \mathrm{m}$ unless otherwise indicated. 


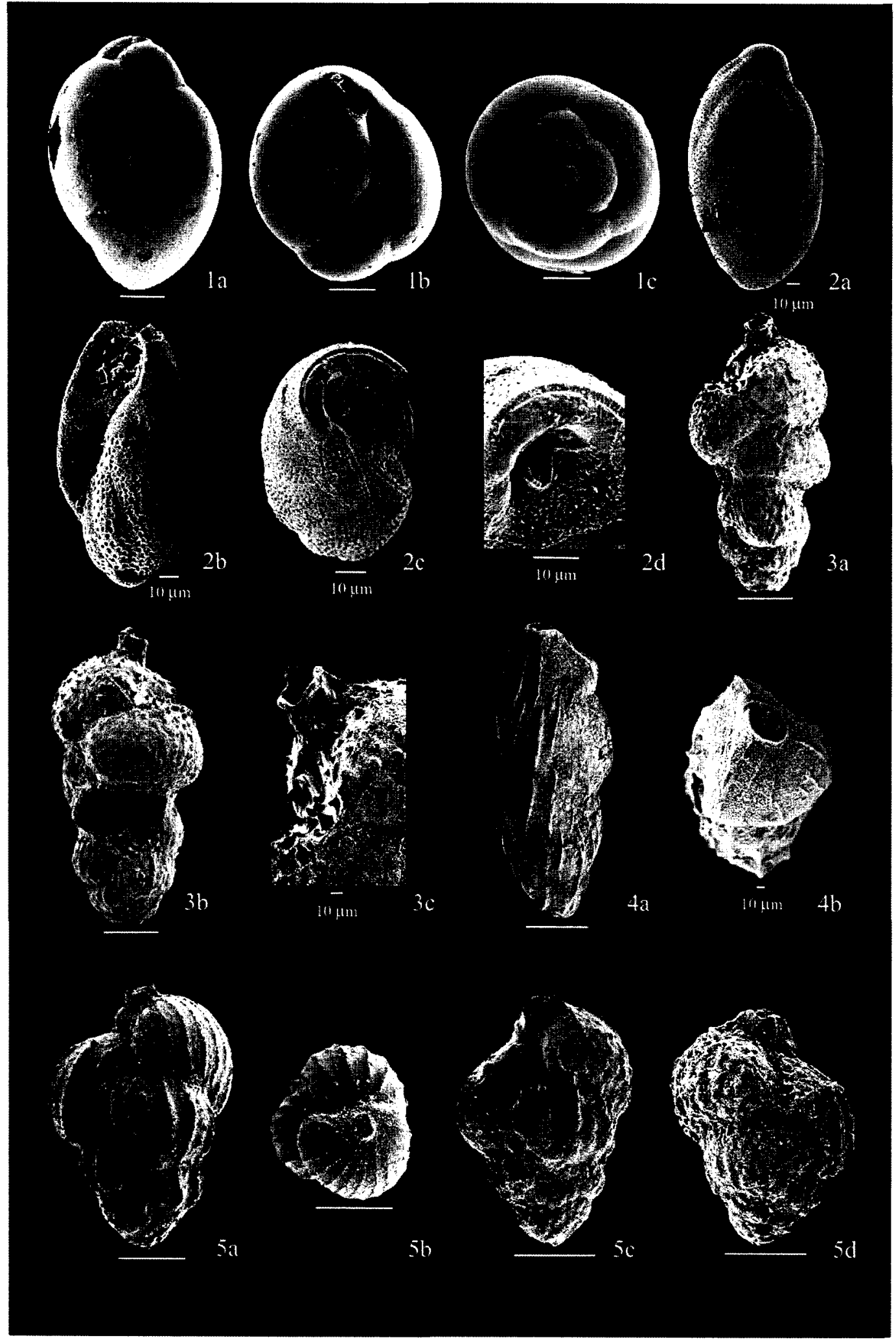


Plate 10:

1.- Gavelinopsis campanulata (Galloway and Wissler), from sample BE1; 1a, dorsal view; $1 \mathrm{~b}$, ventral view showing umbilical plug; $1 \mathrm{c}$, side view showing more convex dorsal side. 2.- Rosalina columbiensis (Cushman), from sample BE1; 2a, dorsal side showing coarse pores; $2 \mathrm{~b}$, ventral view showing aperture extending back along umbilicus; 2c, side view showing lipped marginal aperture. 3.- Epistominella vitrea Parker, from sample BE2; 3a, dorsal side showing smooth test; $3 b$, ventral view showing radial sutures; 3c, side view. 4.- Lobatula fletcheri (Galloway and Wissler), from sample BE1; 4a, dorsal view showing lipped aperture; 4b, ventral view showing coarse perforation; 4c, side view showing well developed umbilical view on spiral side. 5.- Lobatula lobatula (Walker and Jacob), from sample BE1; 5a, dorsal view showing very coarse perforation; $5 \mathrm{~b}$, ventral view showing aperture extending on the last few chambers; $5 \mathrm{c}$, side view showing lipped aperture; $5 \mathrm{~d}$, dorsal view of another specimen with a more ovate outline. All scales are $10 \mu \mathrm{m}$ unless otherwise indicated. 


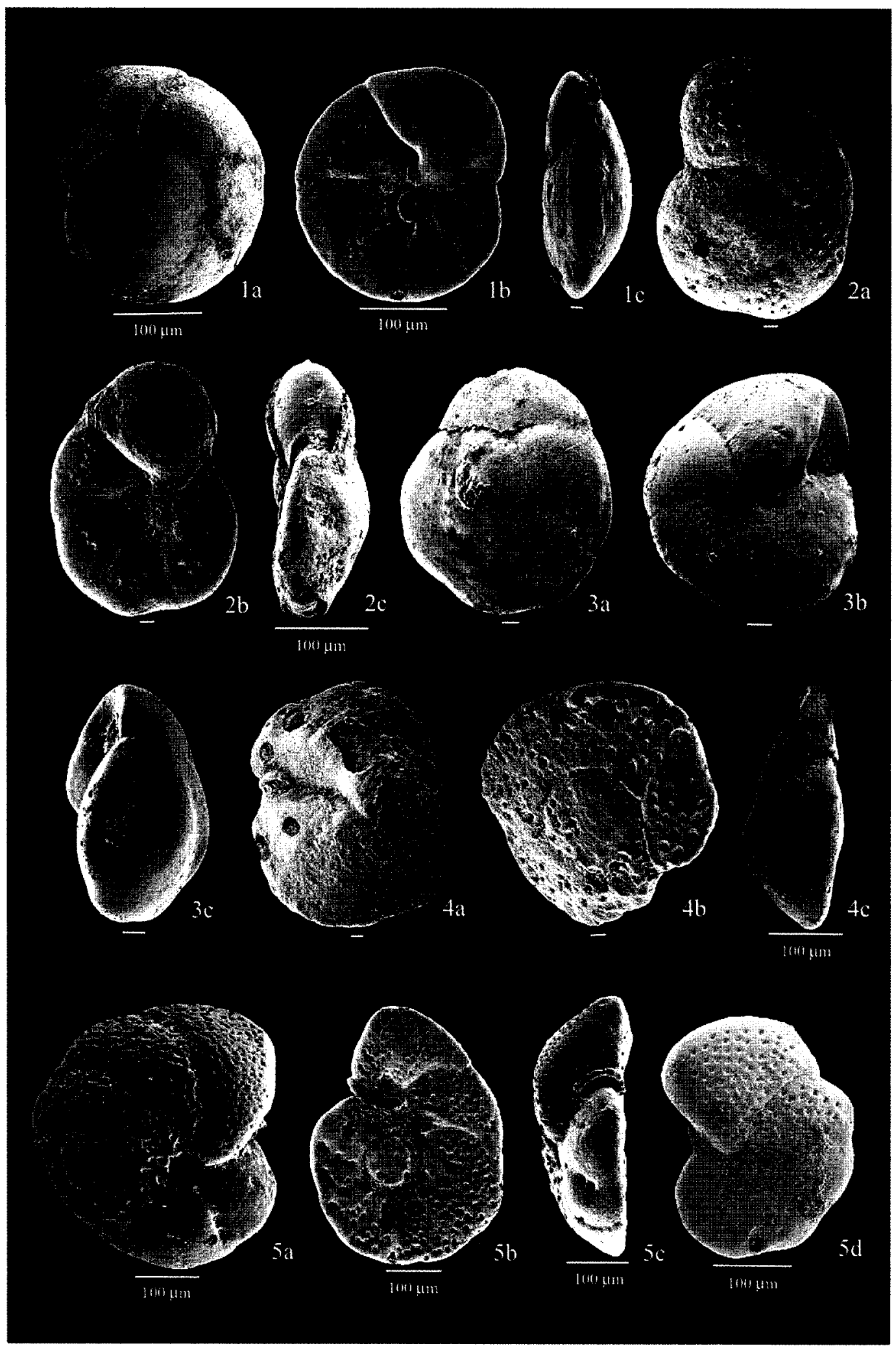


Plate 11:

1.- Lobatula mckannai (Galloway and Wissler), from sample BE1; 1a, dorsal view; $1 \mathrm{~b}$, ventral view covered with debris; $1 \mathrm{c}$, side view showing aperture. 2.Dyocibicides biserialis Cushman and Valentine, from sample BE1; 2a, dorsal view showing irregular outline; $2 \mathrm{~b}$, ventral view showing coarse perforation. 3.- Nonionella stella Cushman and Moyer, from sample BE1; 3a, side view showing umbilical flap extending from broken last chamber and covering the umbilicus; $3 \mathrm{~b}$, view of other side; $3 \mathrm{c}$, apertural view showing basal arcuate aperture. 4.- Nonionella cf. turgida Williamson from sample BE1, side view. 5.- Nonionella digitata Nørvang from sample FC04-76, side view with broken last chamber, showing finger-like projections over umbilicus. 6.- Pseudononion basispinata (Cushman and Moyer) from sample BE2; 6a, side view showing hispid material in open umbilicus; $6 \mathrm{~b}$, apertural view showing compressed test. 7.- Nonionella labradorica (Dawson) from sample BE1; 7a, side view; $7 \mathrm{~b}$, view of the other side showing pustules covering umbilicus; $7 \mathrm{c}$, apertural view showing broad flat apertural face. All scales are $100 \mu \mathrm{m}$ unless otherwise indicated. 


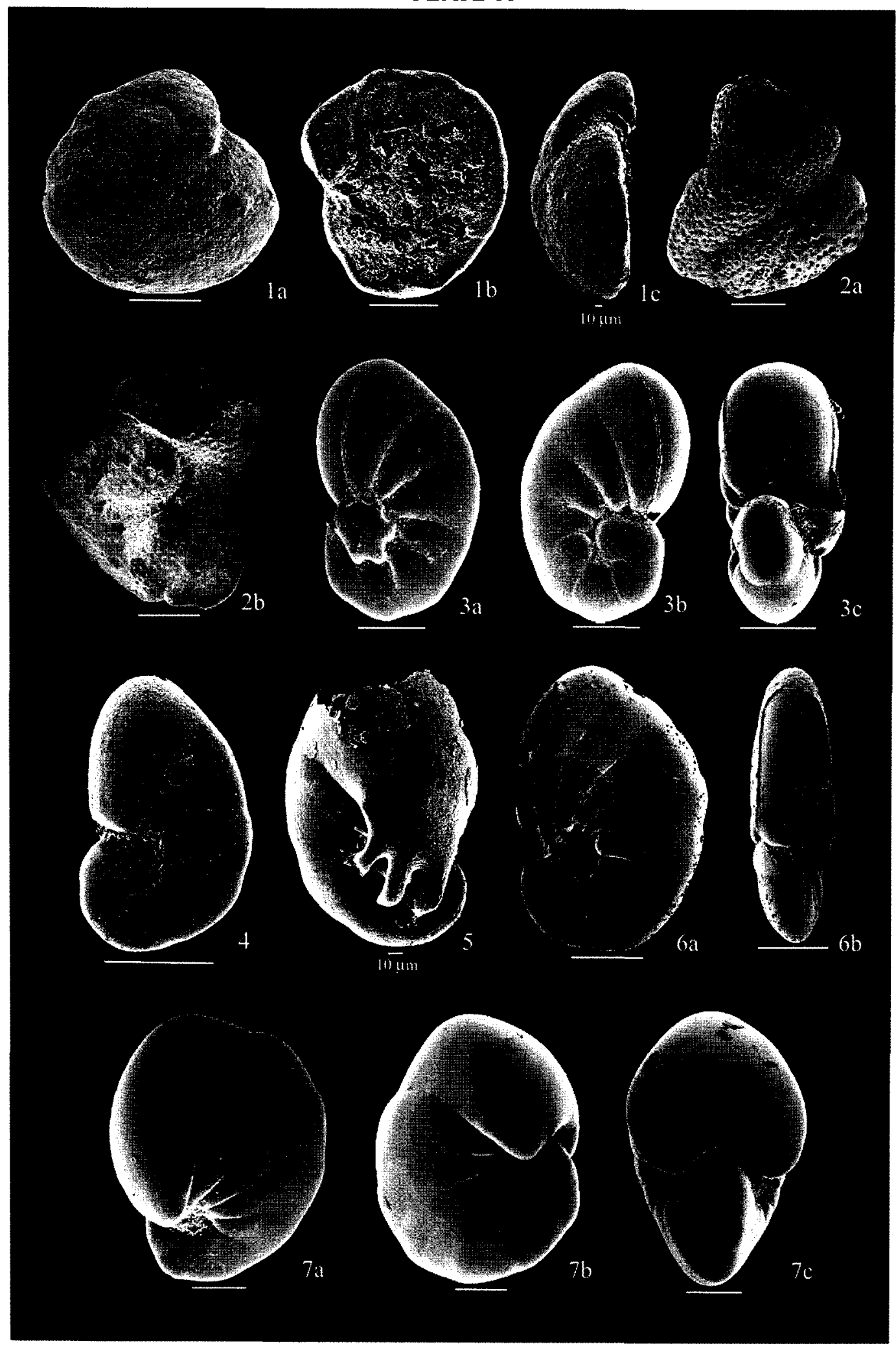


Plate 12:

1.- Astrononion gallowayi Loeblich and Tappan, from sample BE1; 1a, side view showing wedge-shaped supplementary chambers surrounding umbilicus; $1 \mathrm{~b}$, view of the other side showing supplementary apertures at the posterior margin of the supplementary chambers; 1c, apertural view. 2.- Buccella depressa Andersen from sample FC04-39; $2 \mathrm{a}$, dorsal view showing lobulate periphery; $2 \mathrm{~b}$, ventral view. 3.Buccella frigida (Cushman) from sample BE1; 3a, dorsal view showing smooth test; $3 b$, ventral view showing pustules along sutures; $3 c$, side view showing plano-convex test. 4.- Buccella hannai (Phleger and Parker) from sample BE1; 4a, dorsal view; 4b, ventral view showing radial sutures; $4 \mathrm{c}$, side view showing biconvex test and limbate periphery. 5.- Buccella inusitata Andersen from sample BE1; 5a, dorsal view; 5b, ventral view showing thick pustulose coating. 6.- Buccella tenerrima (Bandy) from sample BE1; 6a, dorsal view showing overgrown last chamber; $6 \mathrm{~b}$, ventral view showing 8 chambers; $6 \mathrm{c}$, side view. All scales are $10 \mu \mathrm{m}$ unless otherwise indicated. 


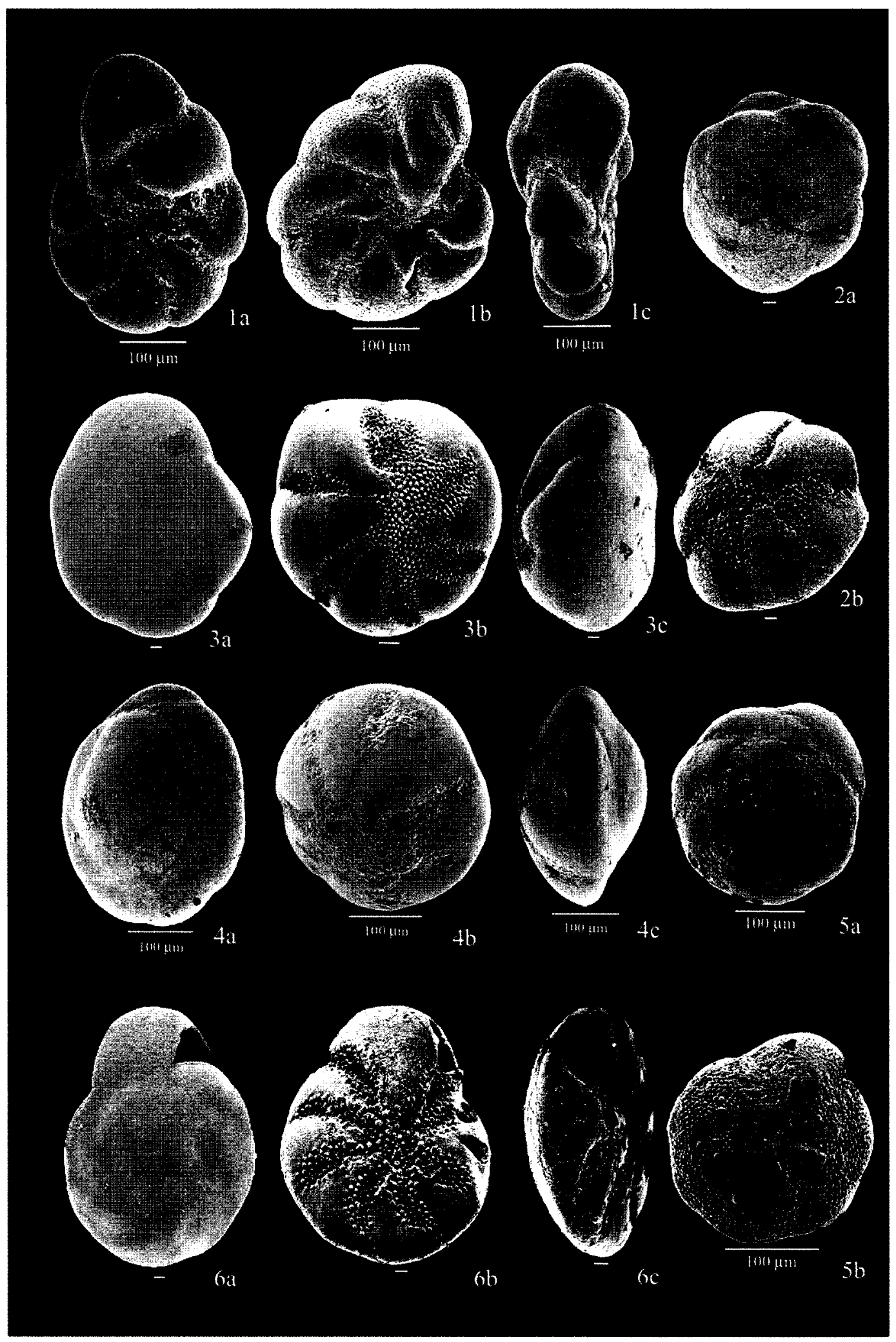


Plate 13:

1.- Cribroelphidium excavatum forma excavata (Terquem); 1a, side view of specimen from sample BE5, showing straight sutures extending unconstricted to the umbilicus; $1 \mathrm{~b}$, apertural view of specimen $1 \mathrm{a} ; 1 \mathrm{c}$, side view of specimen from sample $\mathrm{BE} 1 ; 1 \mathrm{~d}$, apertural view of specimen $1 \mathrm{c} ; 1 \mathrm{~d}$, detail of aperture of specimen $1 \mathrm{c}$, showing pustulose material arranged on triangular patterns on the apertural face. 2.Cribroelphidium excavatum forma lidoensis Cushman, from sample BE1; 2a, side view showing sutures curved backwards, broadening towards the umbilicus, filled with papillae; $2 \mathrm{~b}$, other side; $2 \mathrm{c}$, apertural view. 3.- Cribroelphidium excavatum forma clavata Cushman, from sample BE1; 3a, side view showing umbilical boss and backwards-curved sutures; $3 b$, view of the other side; $3 c$, apertural view. 4.Cribroelphidium excavatum forma selseyensis (Heron-Allen and Earland), from sample BE1; 4a, side view showing granular material filling the umbilicus; 4b, apertural view. 5.- Cribroelphidium excavatum forma magna Miller, from sample FC04-62; 5a, side view showing large umbilicus filled with one knobby boss, and sutures constricted before reaching the umbilicus; 5b, apertural view showing strongly convex walls and raised umbilicus; $5 \mathrm{c}$, view of another specimen from sample FC04-62, with very strongly convex walls that give it an almost circular cross-section. All scales are $10 \mu \mathrm{m}$ unless otherwise indicated. 


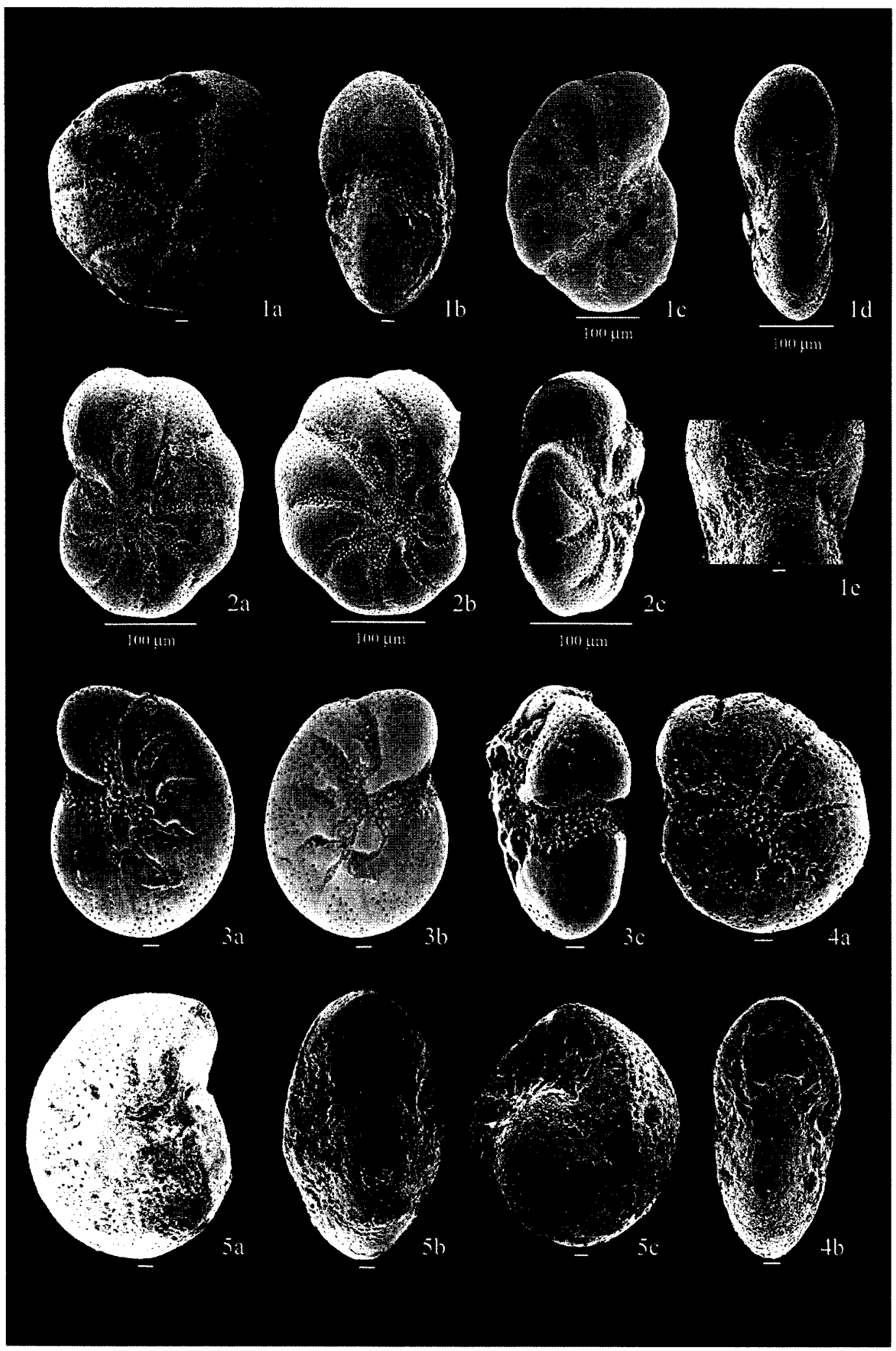


Plate 14:

1.- Cribroelphidium foraminosum (Cushman), from sample BE1; 1a, side view showing coarse perforation, sutural pores and sutural bridges; $1 \mathrm{~b}$, view of the other side; 1c, apertural view showing imperforate apertural face and multiple aperture. 2.- Cribroelphidium microgranulosum (Galloway and Wissler), from sample $\mathrm{BE} 1 ; 2 \mathrm{a}$, side view showing round pores along sutures; $2 \mathrm{~b}$, view of other side showing wall completely covered with pustulose material; $2 \mathrm{c}$, apertural view showing narrow curved aperture. 3.- Cribroelphidium hallandense (Brotzen) from sample $\mathrm{BE} 1 ; 3 \mathrm{a}$, side view showing bands of pustulose material covering umbilicus and along sutures; 3b, view of the other side; 3c, apertural view. 4.- Cribroelphidium magellanicum (Heron-Allen and Earland) from sample BE1; 4a, side view showing very lobulate periphery; $4 \mathrm{~b}$, view of the other side with last chamber broken; $4 \mathrm{c}$, apertural view. 5.- Elphidiella hannai (Cushman and Grant) from sample BE1; 5a, side view showing rounded periphery; $5 \mathrm{~b}$, view of the other side showing thickened flushed sutures with double row of fine pores; 5c, apertural view showing concentration of granular material. All scales are $100 \mu \mathrm{m}$. 


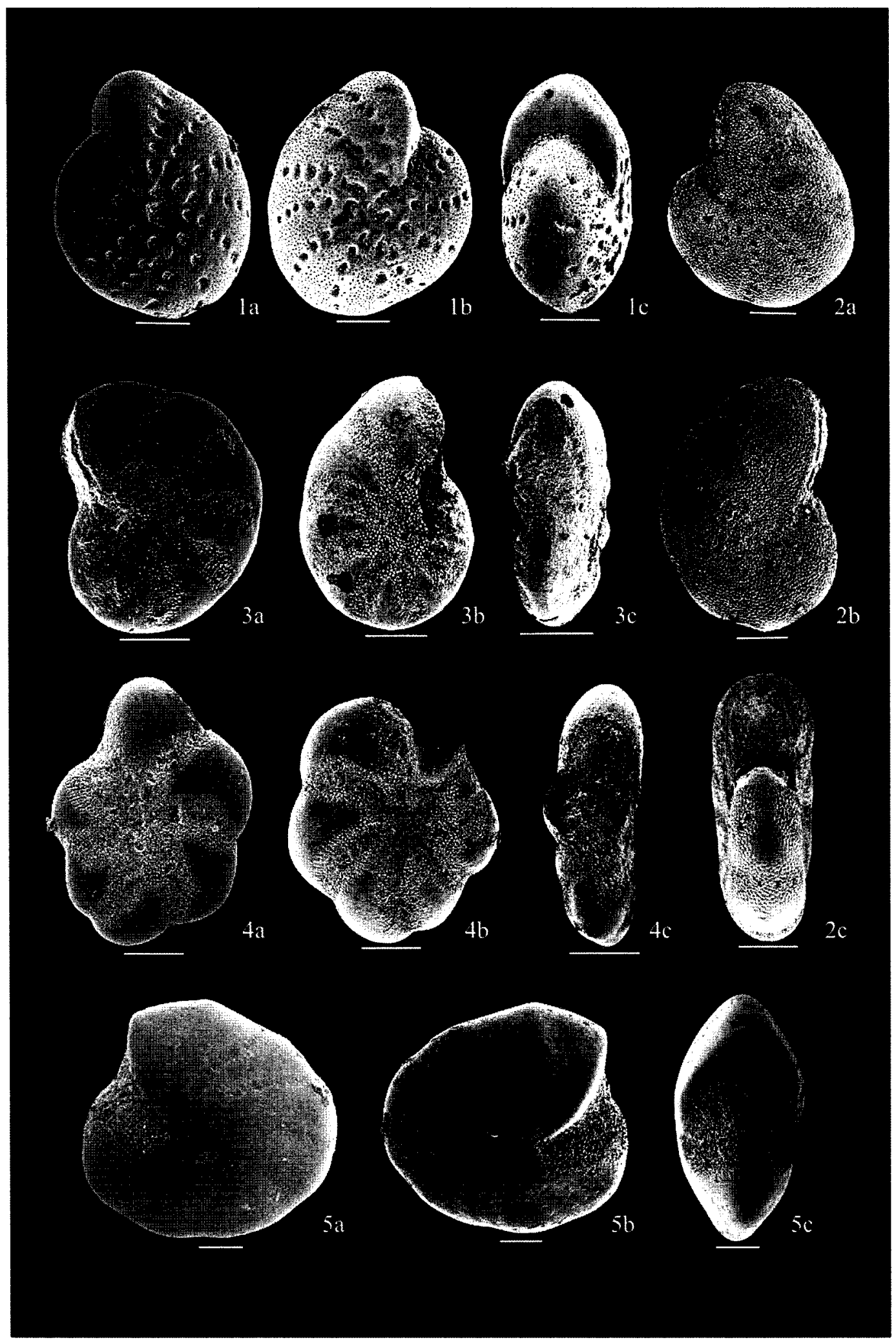


Plate 15:

1.- Globigerinita uvula (Ehrenberg), from sample FC04-64; 1a, dorsal view showing very smooth test; $1 \mathrm{~b}$, ventral view showing low-arched aperture. 2.Globigerina bulloides d'Orbigny from sample FC04-77; 2a, dorsal view showing globular chambers; $2 \mathrm{~b}$, ventral view showing high-arched aperture. 3.- Globigerina quinqueloba Natland from sample FC04-77; 3a, dorsal view showing low trochospiral arrangement; $3 b$, ventral view showing lipped aperture. 4.- Globigerinoides cyclostomus (Galloway and Wissler) from sample BE1; 4a, dorsal view showing ovoid chambers; $4 \mathrm{~b}$, ventral view showing rectangular test outline. 5.- Centropyxis constricta aerophila Reinhardt et al., from sample ..., side view of specimen covered with organic material. 6.- Difflugia oblonga Ehrenberg, from sample ..., side view showing pyriform test. 7.- Difflugia protaeiformis Lamarck, from sample ..., side view showing spine in fundus. 8.- Difflugia urceolata Carter, from sample ..., side view showing cauldron-like test. 9.- Centropyxis constricta constricta Reinhardt et al., from sample FC04-110, showing spines in fundus. 10.- Cyclopyxis kahli (Deflandre), from sample FC04-80, side view showing hemispherical test. 11.Heleopera sphagni (Leidy), from sample FC04-92; 11a, side view showing test entirely composed of idiosomes; $11 \mathrm{~b}$, apertural view showing compressed test and elliptical aperture. All scales are $10 \mu \mathrm{m}$ unless otherwise indicated. 


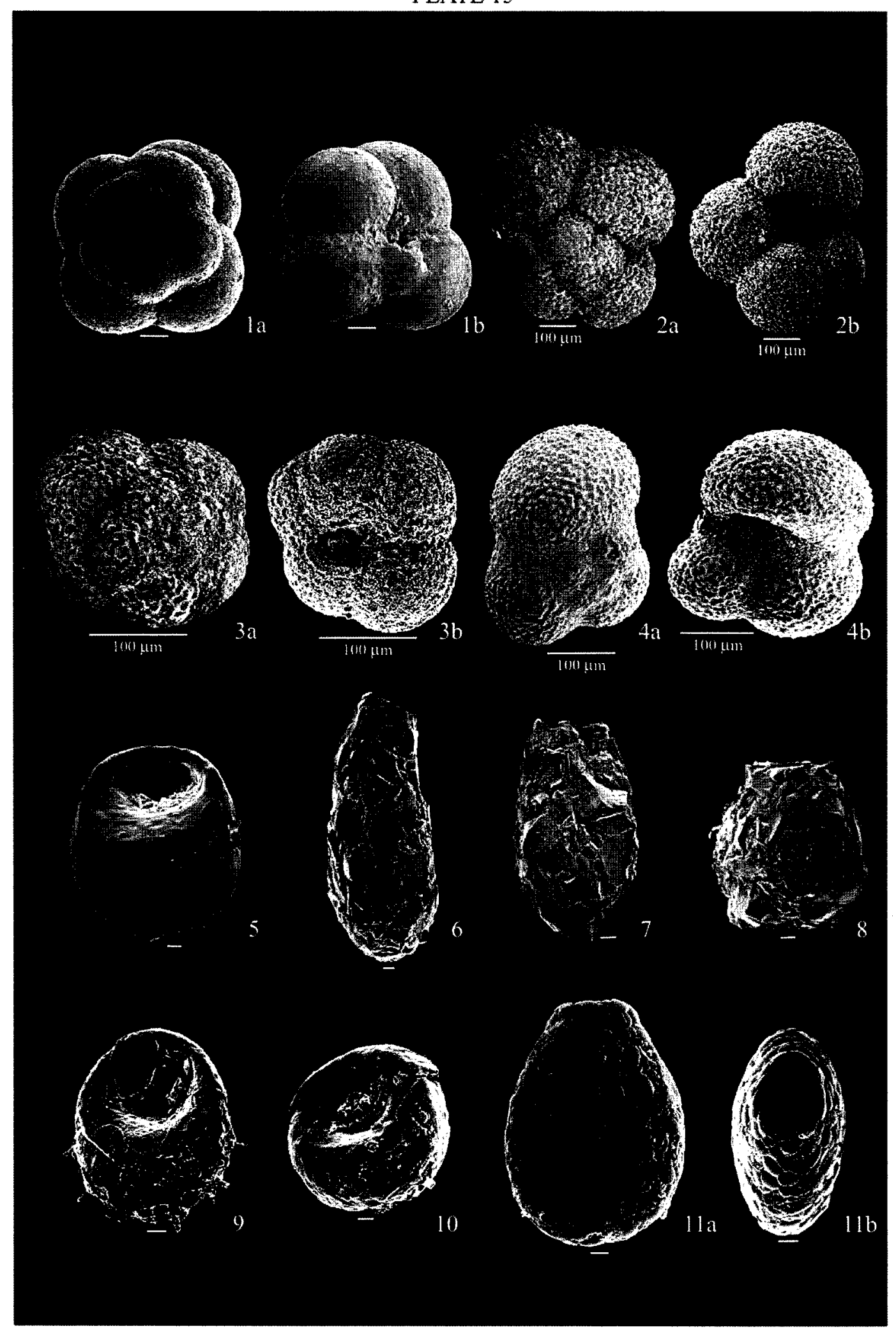




\section{References}

Alekseychik-Mitskevich, L.S., 1973. K klassifikatsii foraminifer semeystva Haplophragmiidae (Towards the classification of the foraminiferal family Haplophragmiidae). Trudy vsesoyuznogo neftyanogo nauchnoissledovatel'skogo geologorazvedochnogo instituta (VNIGRI), 343: 12-44.

Alve, E., 1990. Variations in estuarine foraminiferal biofacies with diminishing oxygen conditions in Drammensfjord, SE Norway. In: C. Hemleben, M.A. Kaminski, W. Kuhnt and D.B. Scott (Editors), Paleoecology, biostratigraphy, paleoceanography and taxonomy of agglutinated foraminifera. NATO ASI Series C: Mathematical and Physical Sciences. Kluwer Academic Publishers, The Netherlands, pp. 661694.

Alve, E., 1991. Foraminifera, climatic change, and pollution: a study of late Holocene sediments in Drammensfjord, southeast Norway. The Holocene, 1(3): 243-261.

Alve, E., 1995. Benthic foraminiferal distribution and recolonization of formerly anoxic environments in Drammensfjord, southern Norway. Marine Micropaleontology, 25: 169-186.

Alve, E., 1996. Benthic foraminiferal evidence of environmental change in the Skagerrak over the past six decades. Bulletin - Norges Geologiske Undersokelse, 430: 85-93. Alve, E., 2000. Environmental stratigraphy. A case study reconstruction bottom water oxygen conditions in Frierfjord, Norway, over the past five centuries. In: R.E. Martin (Editor), Environmental Micropaleontology. Topics in Geobiology. Kluwer Academic/Plenum Publishers., New York, pp. 323-350. 
Alve, E. and Nagy, J., 1986. Estuarine foraminiferal distribution in Sandebukta, a branch of the Oslo Fjord. Journal of Foraminiferal Research, 16(4): 261-284.

Alves Martins, M.V. and Ruivo Dragão Gomes, V.d.C., 2004. Foraminíferos da margem continental NW ibérica: sistemática, ecologia e distribuição. Agenda Comum Comunicação lda., 377 pp.

Andersen, H.V., 1952. Buccella, a new genus of the rotalid foraminifera. Washington Academy of Sciences Journal, 42(5): 148.

Anderson, L., Abbott, M.B., Finney, B.P. and Burns, S.J., 2005. Regional atmospheric circulation change in the North Pacific during the Holocene inferred from lacustrine carbonate oxygen isotopes, Yukon Territory, Canada. Quaternary Research, 64: 21-35.

Appleby, P.G., 2001. Chronostratigraphic techniques in recent sediments. In: W.M. Last and J.P. Smol (Editors), Tracking environmental change using lake sediments. Kluwer Academic Publishers, Dordrecht, The Netherlands, pp. 171-203.

Asano, K., 1936. Pseudononion, a new genus of foraminifera found in Muracks-mura, Kamakura-gori, Kanagawa Prefecture. Journal of the Geological Society of Japan, 43: $347-348$.

Bagg, R.M., Jr., 1912. Pliocene and Pleistocene foraminifera from Southern California. U.S. Geological Survey Bulletin, 513: 45.

Bandy, O.L., 1950. Some later Cenozoic foraminifera from Cape Blanco, Oregon. Journal of Paleontology, 24(3): 278.

Barwell-Clarke, J. and Whitney, F., 1996. Institute of Ocean Sciences nutrient methods and analysis, 182. Canadian Technical Report of Hydrography and Ocean Sciences, 43 pp. 
Beamish, R.J. et al., 1999. The regime concept and natural trends in the production of Pacific salmon. Canadian Journal of Fisheries and Aquatic Sciences, 56(3): 516526.

Bermúdez, P.J., 1961. Contribución al estudio de las Globigerinidea de la region CaribeAntillana (Paleoceno-Reciente). Boletín de Geologia, Venezuela, Publicación Especial, 3: 1119-1393.

Bernhard, J. and Sen Gupta, B.K., 2000. Foraminifera of oxygen-depleted environments. In: B.K. Sen Gupta (Editor), Modern Foraminifera. Kluwer Academic Publishers, Dordrecht, pp. 201-216.

Birks, H.J.B., LIne, J.M., Juggins, S., Stevenson, A.C. and Ter Braak, C.J.F., 1990. Diatoms and $\mathrm{pH}$ reconstruction. Philosophical Transactions of the Royal Society of London, Series B, 327: 263-278.

Blais, A., 1995. Foraminiferal biofacies and Holocene sediments from Saanich Inlet, British Columbia: implications for environmental and neotectonic research. Unpublished Ph.D. thesis Thesis, Carleton University, Ottawa, ON, Canada, 280 pp.

Blais-Stevens, A. and Patterson, R.T., 1998. Environmental indicator potential of foraminifera from Saanich Inlet, Vancouver Island, British Columbia, Canada. Journal of Foraminiferal Research, 28: 201-219.

Bond, G. et al., 2001. Persistent solar influence on North Atlantic Climate during the Holocene. Science, 294: 2130-2136.

Bradley, R.S. and Jones, P.D., 1995. Climate since A.D. 1500. Routledge, New York, USA, 706 pp. 
Brady, G.S. and Robertson, D., 1870. The ostracoda and foraminifera of tidal rivers with an analysis and description of the foraminifera. Annual Magazine of Natural History, 6: 273-309.

Brady, H.B., 1871. On Saccammina carteri, a new foraminifer from the Carboniferous limestone of Northumberland. Annals and Magazine of Natural History, series 4, 7: $177-184$.

Brady, H.B., 1881. Notes on some of the relicularian Rhizopoda of the "Challenger" Expedition; part III. Quarternary Journal of Microscopy Science, London, 21: 50.

Brady, H.B., 1884. Report on the foraminifera dredged by H.M.S. Challenger, during the years 1873-1876, Report on the scientific results of the voyage of the H.M.S. Challenger during the years 1873-1876, Zoology.

Brady, H.B., 1887. A synopsis of the British recent foraminifera. Journal of the Royal Microscopic Society of London, 1887: 893.

Brönnimann, P., 1951. Globigerinita naparimaensis n. gen., n. sp. from the Miocene of Trinidad, B.W.I. Contributions to the Cushman Foundation for Foraminiferal Research, 2: 16-18.

Brönnimann, P. and Whittaker, J.E., 1980. A redescription of Trochammina nana (Brady) (Protozoa: Foraminiferida), with observations on several other recent Trochamminidae in the Collections of the British Museum (Natural History). British Museum of Natural History Bulletin, Zoology Series, 38(4): 181-183.

Brotzen, F., 1943. Appendix. In: I. Hessland (Editor), Marine Schalenablagerungen NordBohusläns. Bulletin of the Geological Institute of the University of Uppsala, pp. 268. 
Buchner, P., 1940. Die Lagenen des Golfes von Neapel und der marinen Ablagerungen auf Ischia. Nova Acta Academiae Cesareae Leopoldino-Carolinae Germanicae Natura Curiosorum, 9(62): 477.

Campeau, S., Pienitz, R. and Héquette, A., 1999. Diatoms as quantitative paleodepth indicators in coastal areas of the southeastern Beaufort Sea, Artic Ocean. Palaeogeography, Palaeoclimatology, Palaeoecology, 146: 67-97.

Carpenter, J.H., 1965. The Chesapeake Bay Institute technique for the Winkler dissolver oxygen method. Limnology \& Oceanography, 10: 141-143.

Carpenter, W.B., 1861. On the systematic arrangement of the Rhizopoda. Natural History Review, 1(4): 456-472.

Carpenter, W.B., 1869. On the rhizopodal fauna of the deep sea. Proceedings of the Royal Society of London, 18: 59-62.

Carpenter, W.B., 1875. The microscope and its revelations. Lindsay and Blakiston, Philadelphia, PA, USA.

Carpenter, W.B., Parker, W.K. and Jones, T.R., 1862. Introduction to the study of the Foraminifera. Ray Society, London.

Carter, H.J., 1864. On freshwater Rhizopoda of England and India. Annuals and Magazine of Natural History, ser. 3, 13: 18-39.

Cayan, D.R. and Peterson, D.H., 1989. The influence of North Pacific atmospheric circulation on streamflow in the west. In: D.H. Peterson (Editor), Aspects of climate variability in the Pacific and the Western Americas. Geophysical Monograph. American Geophysical Union, Washington D.C., USA, pp. 375-398. 
Chang, A.S. and Patterson, R.T., 2005. Climate shift at 4400 years BP: evidence from high-resolution diatom stratigraphy, Effingham Inlet, British Columbia, Canada. Palaeogeography, Palaeoclimatology, Palaeoecology, 226: 72-92.

Chernykh, V.V., 1967. Novye Pozdnesiluriyskie foraminifery Urala (New Late Silurian Foraminifera of the Urals). Paleontologischeskiy Zhurnal, 2: 37-43.

Clague, J.J. et al., 2004. Late Holocene environmental change at treeline in the northern Coast Mountains, British Columbia, Canada. Quaternary Science Reviews, 23: 2413-2431.

Cockbain, A.E., 1963. Distribution of foraminifera in Juan de Fuca and Georgia Straits, British Columbia, Canada. Cushman Foundation for Foraminiferal Research, Contributions, 14: 37-57.

Cushman, J.A., 1910a. A monograph of the foraminifera of the North Pacific Ocean; Part I - Astrorhizidae and Lituolidae. U.S. National Museum Bulletin, 71: 105.

Cushman, J.A., 1910b. A monograph on the foraminifera of the North Pacific Ocean; Part I - Astrorhizidae and Lituolidae. U.S. National Museum Bulletin, 71: 99.

Cushman, J.A., 1911. A monograph of the foraminifera of the North Pacific Ocean, Pt. 2. Textulariidae. Bulletin of the U.S. National Museum, 71(2): 1-108.

Cushman, J.A., 1913. A monograph of the foraminifera of the North Pacific Ocean. Pt. III. Lagenidae. Bulletin of the U.S. National Museum, 71(3): 1-125.

Cushman, J.A., 1922. Results of the Hudson Bay expedition, 1920; I - The foraminifera. Contributions of Canadian Biology, 1921, Biological Board of Canada, 9: 135147.

Cushman, J.A., 1923. The foraminifera of the Atlantic Ocean; Part 4 - Lagenidae. U.S. National Museum Bulletin, 104: 166. 
Cushman, J.A., 1925. Recent foraminifera from British Columbia. Cushman Laboratory for Foraminiferal Research, Contributions, 1: 38-47.

Cushman, J.A., 1926. Foraminifera of the typical Monterey of California. Contributions to the Cushman Foundation for Foraminiferal Research, 2(3): 64.

Cushman, J.A., 1927. An outline of a re-classification of the foraminifera. Contributions to the Cushman Foundation for Foraminiferal Research, 2: 94-95.

Cushman, J.A., 1930. The foraminifera of the Atlantic Ocean, pt. 7: Nonionidae, Camerinidae, Peneroplidae, and Alveolinellidae. U.S. National Museum Bulletin, 104: 79 .

Cushman, J.A., 1933a. Foraminifera, their classification and economic use. Cushman Foundation Special Publication, 4: 1-349.

Cushman, J.A., 1933b. Some new foraminiferal genera. Contributions to the Cushman Foundation for Foraminiferal Research, 9: 1-21.

Cushman, J.A., 1936. Some new species of Elphidium and related genera. Contributions from the Cushman Laboratory for Foraminiferal Research, 12(4): 78-89.

Cushman, J.A., 1937. A monograph of the foraminiferal family Valvulinidae. Cushman Foundation for Foraminiferal Research Special Publication, 7: 1-157.

Cushman, J.A., 1939. A monograph of the foraminiferal family Nonionidae. U.S. Geological Survey, 191: 49.

Cushman, J.A., 1944. Foraminifera from the shallow water of the New England coast. Cushman Foundation for Foraminiferal Research Special Publication, 12: 5.

Cushman, J.A. and Brönnimann, P., 1948. Some new genera and species of foraminifera from brackish water of Trinidad. Contributions from the Cushman Laboratory for Foraminiferal Research, 24: 15-21. 
Cushman, J.A. and Grant, H.S., 1927. Late Tertiary and Quaternary Elphidiums of the West Coast of North America. San Diego Society of Natural History, Transactions, 5(6): 75 .

Cushman, J.A. and McCulloch, I., 1942. Some Virgulininae in the collections of the Allan Hancock Foundation. Allan Hancock Pacific Expeditions, 6: 179-230.

Cushman, J.A. and Moyer, D.A., 1930. Some recent foraminifera from off San Pedro, California. Contributions to the Cushman Foundation for Foraminiferal Research, 6: 56.

Cushman, J.A. and Valentine, W.W., 1930. Shallow-water foraminifera from the Channel Islands of southern California. Contributions from the Department of Geology of Stanford University, 1: 5-51.

d'Orbigny, A., 1826. Tableau méthodique de la classe des Céphalopodes. Annales des Sciences Naturelles, 7: 245-314.

d'Orbigny, A., 1839. Voyage dans l'Amérique Méridionale; Foraminifères, 5. Levrault, Strasbourg, France.

d'Orbigny, A., 1846. Foraminiféres fossiles du bassin tertiare de Vienne (Autriche). Gide et Comp., Paris, 185 pp.

Dawson, J.W., 1860. Notice of Tertiary fossils from Labrador, Maine, etc., and remarks on the climate of Canada in the newer Pliocene or Pleistocene period. Canadian Natural Geology, 5: p. 191.

de Blainville, H.M.D., 1927. Manuel de malacologie et de conchyologie. F.G. Levrault, Paris.

de Monfort, P.D., 1808. Conchyliologie systématique et classification méthodique des coquilles, 1. F. Schoell, Paris. 
Deflandre, G., 1929. Le genre Centropyxis Stein. Archiv fur Protistenkunde, 67: 322375.

Deflandre, G., 1953. Ordres des Testaceolobosa (De Saedeleer 1934), Testaceofilosa (De Saedeleer 1934), Thalamia (Haeckel 1862) ou Thecamoebiens (Auct.) (Rhizopoda Testacea). In: P.-P. Grasse (Editor), Traite de Zoologie. Masson, Paris, pp. 97148.

Defrance, 1824. In: H.M.D.d. Blainville (Editor), Dictionnaire des sciences naturelles, mollus-morf. F.G. Levrault, Paris.

Delage, Y. and Hérouard, E., 1896. Traité de Zoologia Concrète, 1: La cellule at le protozoaires. Schleicher Frères, Paris.

Department of Energy, M.a.R., 1979. Cape Caution, British Columbia (92 M/4). Department of Energy, Mines and Resources, Ottawa.

Earland, A., 1934. Foraminifera; Part III - The Falklands sector of the Antartic (excluding South Georgia). In: C.O. "Discovery" Committee, London (Editor), "Discovery" Repts. University Press, Cambridge, England, pp. 67.

Echols, R.J., 1971. Distribution of foraminifera in sediments of the Scotia Sea area, Antarctic waters. In: J.L. Reid (Editor), Antarctic Oceanography I. Antarctic Research Series. American Geophysical Union, Washington D.C., USA, pp. 93168.

Edwards, R.J. and Horton, B.P., 2000. Reconstructing relative sea-level change using UK salt-marsh foraminifera. Marine Geology, 169(1-2): 41-56.

Edwards, R.J., van de Plassche, O., Gehrels, W.R. and Wright, A.J., 2004. Assessing sealevel data from Connecticut, USA, using a foraminiferal transfer function for tide level. Marine Micropaleontology, 51(3-4): 239-255. 
Ehrenberg, G.C., 1830. Organisation systematik und geographisches Verhaltnis der Infusionsthierchen. Druckerei del Koniglichen Akademie del Wissenschaften, Berlin, 108 pp pp.

Ehrenberg, G.C., 1832. Beitrage zur Kenntnis del Organisation der Infusorien und ihrer geographischen Verbreitung, besonders in Sibirien. Koningliche Akademie der Wissenschaften zu Berlin Abhandlungen: 1-88.

Ehrenberg, G.C., 1838. Über dem blossen Auge unsichtbare Kalkthierchen und Kieselthierchen als Hauptbestandtheile der Kreidegebirge. Bericht uber die zur Bekanntmachung geeigneten Verhanlungen del Koniglichen Preussischen Akademie der Wissenschaften zu Berlin: 192-200.

Ehrenberg, G.C., 1839. Über die Bildung der Kreidefelsen und des Kreidemergels durch unsichtbare Organismen. Physikalische Abhandlungen der Königlichen Akademie der Wissenschaften zu Berlin, 59-147 pp.

Ehrenberg, G.C., 1843. Verbreitung und Einfluss des mikroskopischen Lebens in Sudund Nord-Amerika: Konigliche Akademie der Wissenschaften zu Berlin Abhandlungen, 1841. Physikalische Abhandlungen: 291-446.

Ehrenberg, G.C., 1848. Fortgesetzte Beobachtungen uber jetzt herrschende atmospharische mikroskopische Verhaltnisse. Bericht uber die zur Bekanntmachung geeigneten Verhanlungen del Koniglichen Preussischen Akademie der Wissenschaften zu Berlin, 13: 370-381.

Ehrenberg, G.C., 1861. Elemente des tiejen Meeresgrundes in Mexifanischen Golfstrome bei Florida; Über die Tiefgrund-Verhältnisse des Oceans am Eingange der Davisstrasse und bei Island. K. Preuss. Akad. Wiss. Berlin, Berlin, 315 pp.

Eichwald, C.E.v., 1830. Zoologia specialis, 2. D.E. Eichwaldus, Vilnae, 323 pp. 
Eimer, G.H.T. and Fickert, C., 1899. Die Artibildung und Verwandtschaft bei den Foraminiferen. Entwurf einer natürlichen Eintheilung derselben. Zeitschrift fur wissenschaftliche Zoologie, 65: 599-708.

Feyling-Hanssen, W. and Buzas, M.A., 1976. Emendation of Cassidulina and Islandiella helenae new species. Journal of Foraminiferal Research, 6(2): 154-158.

Fishbein, E. and Patterson, R.T., 1993. Error-weighted maximum likelihood (EWML): a new statistically based method to cluster quantitative micropaleontological data. Journal of Paleontology, 67(3): 475-486.

Fisheries and Oceans, C., 2003. Tides, currents and water levels, pp. www.tides.gc.ca.

Fleming, J., 1828. A history of British animals, exhibiting the descriptive characters and systematic arrangement of the genera and species of quadrupeds, birds, fishes, mollusca and radiata of the United Kingdom. Bell \& Bradfute, Edinburgh.

Galloway, J.J., 1933. A manual of foraminifera. Principia Press, Bloomington.

Galloway, J.J. and Wissler, S.G., 1927. Pleistocene foraminifera from the Lomita Quarry, Palos Verdes Hills, California. Journal of Paleontology, 1: 35-87.

Galloway, J.M., 2006. Post-glacial vegetation and climate change of the Seymour-Belize Inlet Complex, central coastal British Columbia. Ph.D. Thesis, Carleton University, Ottawa, ON.

Gasse, F., Juggins, S. and Ben Khelifa, L., 1995. Diatom-based transfer functions for inferring past hydrochemical characteristics of African lakes. Palaeogeography, Palaeoclimatology, Palaeoecology, 117: 31-54.

Gehrels, W.R., 2000. Using foraminiferal transfer functions to produce high-resolution sea-level records from salt-marsh deposits, Maine, USA. The Holocene, 10(3): $367-376$. 
Gibbs, M.T., Bowman, M.J. and Dietrich, D.E., 2000. Maintenance of near-surface stratification in Doubtful Sound, a New Zealand fjord. Estuarine, Coastal and Shelf Science, 51: 683-704.

Gillibrand, P.A., Turrell, W.R., Moore, D.C. and Adams, R.D., 1996. Bottom water stagnation and oxygen depletion in a Scottish sea loch. Estuarine, Coastal and Shelf Science, 43: 217-235.

Glaessner, M.F., 1937. Die Entfaltung der Foraminiferenfamilie Buliminidae. Problemy Paleontologii, Paleontologicheskaya Laboatoriya Moskovskogo Gosudarstvennogo Universiteta, 2-3: 411-422.

Green, M.A., Aller, R.C. and Aller, J.Y., 1993. Carbonate dissolution and temporal abundances of Foraminifera in Long Island Sound sediments. Limnology \& Oceanography, 38(2): 331-345.

Green, R.N. and Klinka, K., 1994. A field guide to site identification and interpretation for the Vancouver Forest Region, Land Management Handbook No. 28. British Columbia Ministry of Forests, 285 pp.

Guilbault, J.P., Patterson, R.T., Thomson, R.E., Barrie, J.V. and Conway, K., 1997. Late Quaternary paleoceanographic changes in Dixon Entrance, Northwest British Columbia, Canada: evidence from the foraminiferal faunal succession. Journal of Foraminiferal Research, 27(3): 151-174.

Guilbault, J.P., Radi, T., Barrie, J.V., Conway, K. and Lapointe, M., 2003. Paleoenvironments of the Strait of Georgia, British Columbia during the last deglaciation: Microfaunal and microfloral evidence. Quaternary Science Reviews, 22(8-9): 839-857. 
Gustafsson, M. and Nordberg, K., 2000. Living (stained) benthic foraminifera and their response to the seasonal hydrographic cycle, periodic hypoxia and to primary production in Havstens Fjord on the Swedish West coast. Estuarine, Coastal and Shelf Science, 51: 743-761.

Gustafsson, M. and Nordberg, K., 2002. The impact of climate and shore-level displacement on the late-Holocene environmental development of Havstens Fjord and Koljo Fjord, Swedish west coast. The Holocene, 12: 325-338.

Haeckel, E., 1894. Systematische Phylogenie. Entwurf eines Natürlichen Systems der Organismen auf Grund ihrer Stammesgeschichte. Systematische Phylogenie der Protisten und Pflanzen, 1. Georg Reimer, Berlin.

Haman, D., 1982. Modern Thecamoebinids (Arcellinida) from the Balize Delta, Louisiana. Transactions, Gulf Coast Association of Geological Societies, 32: 353376.

Hare, F.K. and Thomas, M.K., 1979. Climate Canada. John Wiley \& Sons, Toronto, 256 pp.

Harmon, R.A., 1972. The distribution of microbiogenic sediment near the mouth of the Columbia River. In: A.T. Pruter and D.L. Alverson (Editors), The Columbia River estuary and adjacent ocean waters. University of Washington Press, Seattle, WA, pp. 265-277.

Hedley, R.H., Hurdle, C.M. and Burdett, I.D.J., 1964. Trochammina squamata Jones and Parker (foraminifera) with observations on some closely related species. New Zealand Journal of Science, 7(3): 419-425. 
Heron-Allen, E. and Earland, A., 1911. On the recent and fossils foraminifera of the shore-sands of Selsey Bill, Sussex, IV. Journal of the Royal Microscopy Society: 436-448.

Heron-Allen, E. and Earland, A., 1930. Some new foraminifera for the South Atlantic; III. Miliammina, a new siliceous genus. Journal of the Royal Microscopical Society of London, ser. 3, 50: 38-45.

Heron-Allen, E. and Earland, A., 1932. Foraminifera; Part I - The ice-free area of teh Falkland Islands and adjacent seas, "Discovery" Reports, issued by the "Discovery" Committee, Colonial Office, London. University Press, Cambridge, UK, pp. 440.

Hofker, J., 1951. The foraminifera of the Siboga expedition. Part III. Siboga-Expeditie, Monographie IVa. E.J. Brill, Leiden, 513 pp.

Hofker, J., 1956. Tertiary foraminifera of coastal Ecuador: Part II, Additional notes on the Eocene species. Journal of Paleontology, 30: 891-958.

Höglund, H., 1947. Foraminifera in the Gullmar Fjord and the Skagerak, Uppsala University, Uppsala.

Höglund, H., 1948. New names for four homonym species described in "Foraminifera in the Gullmar Fjord and the Skagerak". Contributions to the Cushman Foundation for Foraminiferal Research, 24: 45.

Hu, F.S. et al., 2003. Cyclic variation and solar forcing of Holocene climate in the Alaskan Subartic. Science, 301: 1890-1893.

Husezima, R. and Maruhasi, M., 1944. A new genus and thirteen new species of foraminifera from the core-sample of Kasiwazaki oil field, Niigata-ken. Journal Sigenkagaku Kenkyusyo, 1(3): 391-400. 
Husum, K. and Hald, M., 2004. Modern foraminiferal distribution in the subartic Malangen Fjord and adjoining shelf, Northern Norway. Journal of Foraminiferal Research, 34(1): 34-48.

Hutchinson, I., James, T.S., Reimer, P.J., Bornhold, B.D. and Clague, J.J., 2004. Marine and limnic radiocarbon reservoir corrections for studies of late- and postglacial environments in Georgia Basin and Puget Lowland, British Columbia, Canada and Washington, USA. Quaternary Research, 61: 193-203.

Ingram, B.L. and Southon, J.R., 1996. Reservoir ages in eastern Pacific coastal and estuarine waters. Radiocarbon, 38(3): 573-582.

Jonasson, K.E., 1994. Benthic foraminiferal distribution at Middle Valley, Juan de Fuca Ridge: a northeast Pacific hydrothermal venting site, Carleton University, Ottawa, ON, Canada, 127 pp.

Jonasson, K.E. and Patterson, R.T., 1992. Preservation potential of marsh foraminifera from the Fraser Rivel Delta, British Columbia. Micropaleontology, 38: 289-301.

Jones, 1875. In: J.W. Griffith and A. Henfrey (Editors), The micrographic dictionary. van Voorst, London.

Jones, D.S. and Ross, C.A., 1979. Seasonal distribution of foraminifera in Samish Bay, Washington. Journal of Paleontology, 53: 245-257.

Jones, R.W., 1984. A revised classification of the unilocular Nodosariida and Buliminida (Foraminifera). Revista Española de Micropaleontología, 16: 91-160.

Jones, T.R. and Parker, W.K., 1860. On the Rhizopodal fauna of the Mediterranean, compared with that of the Italian and some other Tertiary deposits. Quarternary Journal of the Geological Society of London, 16: 304. 
Juggins, S., 2005. C2 Version 1.4: Software for ecological and palaeoecological data analysis and visualisation. University of Newcastle, Newcastle upon Tyne.

Kaartvedt, S. and Svendsen, H., 1990. Impact of freshwater runoff on physical oceanography and plankton distribution in a Western Norwegian fjord: an experiment with a controlled discharge from a hydroelectric power plant. Estuarine, Coastal and Shelf Science, 31: 381-395.

Kaiho, K., 1994. Benthic foraminiferal dissolved-oxygen index and dissolved-oxygen levels in the modern ocean. Geology, 22: 719-722.

Kent, W.S., 1880. A manual of the Infusoria: including a description of all known Flagellate, Ciliate, and Tentaculiferous Protozoa, British and foreign, and an account of the organisation and affinities of the Sponges. Bogue, 1: 1-472.

Kiaer, H., 1900. Synopsis of the Norwegian marine Thalamophora. Norwegian Fisheries Marine Investigation, 1(7): 24.

Klitgaard-Kristensen, D. and Buhl-Mortensen, L., 1999. Benthic foraminifera along an offshore-fjord gradient: a comparison with amphipods and molluscs. Journal of Natural History, 33(3): 317-350.

Knudsen, K.L. and Seidenkrantz, M.-S., 1994. Stainforthia feylingi new species from artic to subartic environments, previously recorded as Stainforthia schreibersiana (Czjzek). Cushman Foundation for Foraminiferal Research Special Publication, 32: 5-13.

Kumar, A. and Dalby, A.P., 1998. Identification key for Holocene lacustrine Arcellacean (Thecamoebian) taxa. Palaeontologia Electronica, 1(1): 34 http://www.palaeoelectronica.org/1998 1/dalby/issue1.htm. 
Kumar, A. and Patterson, R.T., 2005. Foraminifera evidence of subaqueous debris flows at ODP site 1033 (Leg 169S), Saanich Inlet, Vancouver Island, Canada. Journal of the Palaeontological Society of India, 50(2): 121-134.

Lamarck, J.B., 1816. Histoire naturelle des animaux sans vertebres, 2. Verdiere, Paris, 568 pp. pp.

Lassen, S.J. et al., 2004. Late-Holocene Atlantic bottom-water variability in Igaliku Fjord, South Greenland, reconstructed from foraminifera faunas. The Holocene, 14: $165-171$.

Leidy, J., 1874. Notice of some Rhizopods. Academy of Natural Sciences of Philadelphia Proceedings, ser. 3, 1874: 13-15.

Leidy, J., 1879. Fresh-water Rhizopods of North America. United States Geological Survey of the Territories Report, 12: 1-324.

Leps, J. and Smilauer, P., 2003. Multivariate analysis of ecological data using CANOCO. Cambridge University Press, Cambridge, UK, 269 pp.

Loeblich, A.R. and Tappan, H., 1953. Studies of Artic foraminifera. Smithsonian Miscellaneous Collections, 121. Smithsonian Institution, Washington, USA, 150 pp.

Loeblich, A.R. and Tappan, H., 1954. New names for two foraminiferal homonyms. Journal of the Washington Academy of Sciences, 44: 384.

Loeblich, A.R. and Tappan, H., 1961. Remarks on the systematics of the Sarcodina (Protozoa), renamed homonyms and new and validated genera. Proceedings of the Biological Society of Washington, 74: 213-234.

Loeblich, A.R. and Tappan, H., 1987. Foraminiferal genera and their classification. Van Norstrand Reinhold Company, New York, 2047 pp. 
Mathewes, R.W., Heusser, L.E. and Patterson, R.T., 1993. Evidence for a Younger Dryas-like cooling event on the British Columbia coast. Geology, 21: 101-104.

Maync, W., 1952. Critical taxonomy study and nomenclatural revision of the Lituolidae based upon the prototype of the family, Lituola nautiloidea Lamarck, 1804. Contributions to the Cushman Foundation for Foraminiferal Research, 3: 35-56.

McCulloch, I., 1977. Qualitative observations on Recent foraminiferal tests with emphasis on the eastern Pacific. University of Southern California, Los Angeles, California, $1078 \mathrm{pp}$.

Medioli, F.S. and Scott, D.B., 1983. Holocene Arcellacea (Thecamoebians) from eastern Canada. Cushman Foundation Special Publication, 21: 63.

Miller, A.A.L., Scott, D.B. and Medioli, F.S., 1982. Elphidium excavatum (Terquem): ecophenotypic versus subespecific variation. Journal of Foraminiferal Research, 12(2): 116-144.

Miller, A.J., Cayan, D.R., Barnett, T.P., Graham, N.E. and Oberhuber, J.M., 1994. The 1976-77 climate shift of the Pacific Ocean. Oceanography, 7(1): 21-26.

Montagu, G., 1803. Testacea Britannica, or natural history of British shells, marine, land and fresh-water, including the most minute. J.S. Hollis, Romsey, England, 524 pp.

Murray, J., 1991. Ecology and palaeoecology of benthic Foraminifera. Logan Scientific \& Technical, Avon, $397 \mathrm{pp}$.

Murray, J., Alve, E. and Cundy, A., 2003. The origin of modern agglutinated foraminiferal assemblages: evidence from a stratified fjord. Estuarine, Coastal and Shelf Science, 58: 677-697.

Murray, J.W., 1971. An atlas of British recent Foraminiferids. Heinemann Educational Books Ltd., London, 244 pp. 
Murray, J.W., 1973. Distribution and ecology of living benthic foraminiferids.

Heinemann Educational Books Ltd., London, UK, 274 pp.

Murray, J.W., 2003. An illustrated guide to the benthic foraminifera of the Hebridean Shelf, west of Scotland, with notes on their mode of life. Palaeontologia Electronica, 5(1): 31 .

Natland, M.L., 1938. New species of foraminifera from off the west coast of North America and from the later Tertiary of the Los Angeles Basin. Scripps Institute of Oceanography Bulletin, Technical Series, 4(5): 146.

Nederbragt, A.J. and Thurow, J.W., 2001. A 6000 yr varve record of Holocene climate in Saanich Inlet, British Columbia, from digital sediment colour analysis of ODP Leg 169S cores. Marine Geology, 174: 95-110.

Neumann, T., Christiansen, C., Clasen, S., Emeis, K.C. and Hunzendorf, H., 1997. Geochemical records of salt-water inflow into the deep basins of the Baltic Sea. Continental Shelf Research, 17(1): 95-115.

Norman, A.M., 1892. Museum Normanianum, Durham, England.

Nørvang, A., 1945. Foraminifera. Zoology of Iceland, 2(2): 1-79.

Nørvang, A., 1959. Islandiella n.g. and Cassidulina d'Orbigny. Videnskabelige Meddeleser fra Dansk Naturhistorisk Forening i Kjøbenhavn, 120: 25-41.

Parker, F.L., Phleger, F.B. and Peirson, J.F., 1953. Ecology of foraminifera from San Antonio Bay and environs, southwest Texas. Cushman Foundation for Foraminiferal Research Special Publication, 2: 9.

Parker, W.C. and Arnold, A.J., 1999. Quantitative methods of data analysis in foraminiferal ecology. In: B.K. Sen Gupta (Editor), Modern foraminifera. Kluwer Academic Publishers, Cornwall, UK, pp. 71-89. 
Parker, W.K. and Jones, T.R., 1859. On the nomenclature of the foraminifera. II. On the species enumerated by Walker and Montagu. Annals and Magazine of Natural History, series 3, 4: 333-351.

Parker, W.K. and Jones, T.R., 1865. On some foraminifera form the North Atlantic and Artic Oceans, including Davis Straits and Baffin's Bay. Royal Society of London Philosophical Transactions, 155: 370.

Parr, W.J., 1947. The Lagenid foraminifera and their relationships. Proceedings of the Royal Society of Victoria, 58: 116-130.

Parr, W.J., 1950. Foraminifera. B.A.N.Z. Antartic Research Expedition 1929-1931, Reports, 5(6): 27 .

Patterson, R.T., 1990a. Intertidal benthic foraminiferal biofacies on the Fraser River Delta, British Columbia: modern distribution and paleoecological importance. Micropaleontology, 36(3): 229-244.

Patterson, R.T., 1990b. New and renamed species of benthic foraminifera from the Pleistocene Santa Barbara formation of California. Journal of Paleontology, 64(5): 681-691.

Patterson, R.T., 1993. Late Quaternary benthic foraminiferal biofacies and paleoceanography of Queen Charlotte Sound and southern Hecate Strait, British Columbia. Journal of Foraminiferal Research, 23(1): 1-18.

Patterson, R.T., Burbidge, S.M. and Luternauer, J.L., 1998. Atlas of common benthic foraminiferal species for Quaternary shelf environments of western Canada. Bulletin - Geological Survey of Canada, 503, 91 pp. 
Patterson, R.T. and Cameron, B.E.B., 1991a. Foraminiferal biofacies succession in the Late Quaternary Fraser River delta, British Columbia. Journal of Foraminiferal Research, 21(3): 228-243.

Patterson, R.T. and Cameron, B.E.B., 1991b. Paleoenvironmental significance of the foraminiferal biofacies succession in the Late Quaternary sediments of the Fraser River Delta, British Columbia. Journal of Foraminiferal Research, 21: 228-243.

Patterson, R.T. and Fishbein, E., 1989. Re-examination of the statistical methods used to determine the number of point counts needed for micropaleontological quantitative research. Journal of Paleontology, 63: 245-248.

Patterson, R.T., Gehrels, W.R., Belknap, D.F. and Dalby, A.P., 2004a. The distribution of salt marsh foraminifera at Little Dipper Harbour, New Brunswick, Canada: implications for development of widely applicable transfer functions in sea-level research. Quaternary International, 120(1): 185-194.

Patterson, R.T., Guilbault, J.-P. and Thomson, R.E., 2000. Oxygen level control on foraminiferal distribution in Effingham Inlet, Vancouver Island, British Columbia, Canada. Journal of Foraminiferal Research, 30(4): 321-335.

Patterson, R.T. and Kumar, A., 2002. Post-glacial paleoceanographic history of Saanich Inlet, British Columbia, based on foraminiferal proxy data. Journal of Foraminiferal Research, 32(2): 110-125.

Patterson, R.T., Prokoph, A., Reinhardt, E.D. and Roe, H.M., 2006. Climate cyclicity in late Holocene marine sediments from the Seymour-Belize Inlet Complex, British Columbia. Marine Geology, submitted.

Patterson, R.T. et al., 2004b. Holocene solar variability and pelagic fish productivity in the NE Pacific. Palaeontologia Electronica, 7(1): Art. 2, 17 pp. 
Patterson, R.T. and Richardson, R.H., 1988. Eight new genera of unilocular Foraminifera. Transactions American Microscopical Society, 107(3): 240-258.

Phleger, F.B. and Parker, F.L., 1951. Ecology of Foraminifera, northwest Gulf of Mexico. Geological Society of America Memories, 46: 21.

Pickard, G.L., 1961. Oceanographic features of inlets in the British Columbia mainland coast. Journal of the Fisheries Research Board of Canada, 18(6): 907-999.

Pickard, G.L. and Stanton, B.R., 1980. Pacific fjords - a review of their water characteristics. In: H.J. Freeland, D.M. Farmer and C.D. Levings (Editors), Fjord Oceanography (Proceedings of the NATO conference on fjord oceanography, Victoria, BC, 1979). Plenum Press, New York, USA, pp. 1-51.

Poag, C.W., 1981. Ecologic atlas of benthic foraminifera of the Gulf of Mexico. Marine Science International, Woods Hole, Massachusetts, 174 pp.

Polyak, L. et al., 2002. Benthic foraminiferal assemblages from the Southern Kara Sea, a river-influenced artic marine environment. Journal of Foraminiferal Research, 32(3): 252-273.

Polyak, L., Murdmaa, I. and Ivanova, E., 2004. A high resolution, 800-year glaciomarine record from Russkaya Gavan', a Novaya Zemlya fjord, eastern Barents Sea. The Holocene, 14(4): 628-634.

Puri, H.S., 1953. Contribution to the study of the Miocene of the Florida panhandle. Geological Bulletin, 36. The Florida Geological Survey, Tallahasse, Florida., 345 pp.

Reimer, P.J. et al., 2004. IntCal04 terrestrial radiocarbon age calibration, 0-26 Cal Kyr BP. Radiocarbon, 46(3): 1029-1058. 
Reinhardt, E.D., Dalby, A.P., Kumar, A. and Patterson, R.T., 1998. Utility of arcellacean morphotype variants as pollution indicators in mine tailing contaminated lakes near Cobalt, Ontario, Canada. Micropaleontology, 44: 1-18.

Reinhardt, E.D., Easton, N.A. and Patterson, R.T., 1996. Foraminiferal evidence of Late Holocene sea-level change and Amerindian site distribution at Montague Harbour, British Columbia. Géographie physique et Quaternaire, 50(1): 35-46.

Reiss, Z., 1963. Reclassification of perforate foraminifera. Bulletin of the Geological Survey of Israel, 35: 1-111.

Resig, J.M., 1963. Size relationships of Eggerella advena to sediment and depth of substratum. Essays in Marine Geology in honor of K.O. Emery: 121-126.

Reuss, A.E., 1850. Neues Foraminiferen aus den Schichten des österreichischen Tertiärbeckens. Denkschriften der Kaiserlichen Akademie del Wissenschaften, Mathematisch-Naturwissenschafliche Classe, 1: 365-390.

Reuss, A.E., 1860. Die Foraminiferen der Westphäalischen Kreideformation. Sitzungsberichte der Kaiserlichen Akademie der Wissenschaften in Wien, Mathematisch-Naturwissenschaftliche Classe, 40: 147-238.

Reuss, A.E., 1862. Entwuf einer systematischen Zusammenstellung der Foraminiferen. Sitzungsberichte der Kaiserlichen Akademie der Wissenschaften in Wien, Mathematisch-Naturwissenschaftliche Classe, 44(1): 355-396.

Risso, A., 1826. Histoire naturelle des principales productions de l'Europe Méridionale et particulièrment de celles des environs de Nice et des Alpes Maritimes, 4. F.G.Levrault, Paris.

Rodrigues, C.G., 1980. Holocene microfauna and paleoceanography of the Gulf of St. Lawrence. Ph.D. Thesis, Carleton University, Ottawa, Canada, 352 pp. 
Sageman, B.B. and Bina, C.R., 1997. Diversity and specices abundance patterns in Late Cenomanian black shale biofacies, Western Interior, US. Palaios, 12: 449466.

Saidova, K.M., 1975. Bentosnye Foraminifery Tikhogo Okeana (Benthonic foraminifera of the Pacific Ocean). Institu Okeanologii P.P. Shirshova, Akademiya Nauk SSSR, Moscow.

Saidova, K.M., 1981. O sovremennom sostoyanii sistemy nadvidovykh Kaynozoyskikh bentosnikh foraminifer (On an up-to-date system of supraspecific taxonomy of Cenozoic benthonic foraminifera). Institut Okeanologii P.P.Shirshova, Akademiya Nauk, SSSR, Moscow.

Saito, T., Thompson, P.R. and Breger, D., 1981. Recent and Pleistocene planktonic foraminifera. University of Tokyo Press, Tokyo, $190 \mathrm{pp}$.

Schafer, C.T., Cole, F.E. and Syvitski, J.P.M., 1989. Bio- and lithofacies of modern sediments in Knight and Bute Inlets, British Columbia. Palaios, 4: 107-126.

Schlitzer, R., 2004. Ocean Data View. http://odv.awi-bremerhaven.de.

Schmarda, L.K., 1871. Zoologie: Band I. Braumüller, Wien, 372 pp.

Schröder, C., 1986. Deep-water arenaceous Foraminifera in the northwest Atlantic Ocean. Canadian Technical Report of Hydrography and Ocean Sciences, 71. Bedford Institute of Oceanography, Dartmout, NS, Canada, $190 \mathrm{pp}$.

Schröder, C., Scott, D.B. and Medioli, F.S., 1987. Can smaller benthic foraminifera be ignored in paleoenvironmental analyses? Journal of Foraminiferal Research, 17: 101-109. 
Schultze, M.S., 1854. Über den Organismus der Polythalamien (Foraminiferen), nebst

Bermekungen über die Rhizopoden im Allgemeinen. Wilhelm Engelmann, Leipzig.

Schulze, F.E., 1877. Rhizopodenstudien VI. Archiv fur Mikroskopische Anatomie, 13: 930.

Schwager, C., 1866. Fossile foraminiferan von kar-nicobar: reise der osterreichischen fregatte novarra. Geologica Theil, 2: 187-268.

Schwager, C., 1876. Saggio di una classificazione dei foraminiferi auto riguarddo alle loro famiglie naturali. Bolletino R. Comitato Geologico d'Italia, 7: 475-485.

Schwager, C., 1877. Quadro del proposto sistema di classificazione dei foraminiferi con guscio. Bolletino R. Comitato Geologico d'Italia, 8: 18-27.

Scott, D.B. and Medioli, F.S., 1983. Agglutinated rizhopods in Lake Erie: modern distribution and stratigraphic implications. Journal of Paleontology, 57(4): 809820.

Scott, D.B., Medioli, F.S. and Schafer, C.T., 2001. Monitoring in coastal environments using foraminifera and thecamoebian indicators. Cambridge University Press, Cambridge, UK.

Sen Gupta, B.K., 1999. Foraminifera in marginal marine environments. In: B.K. Sen Gupta (Editor), Modern Foraminifera. Kluwer Academic Publishers, Dordrecht, pp. 141-159.

Sen Gupta, B.K. and Machain-Castillo, M.L., 1993. Benthic foraminifera in oxygen-poor habitats. Marine Micropaleontology, 20: 183-201.

Shannon, C.E. and Weaver, W., 1949. The mathematical theory of communication. University of Illinois Press., Urbana. 
Sigal, J., 1952. Aperçu stratigraphiquesur la micropaléontologie du Crétacé, XIX Congrés Géologique International. Monographies Régionales, série I, Algérie, pp. $1-47$.

Silvestri, A., 1923. Lo stipite della Elissoforme e le sue affinità. Memorie della Pontificia Accademia della Scienze, Nuovi Lincei, ser. 2, 6: 231-270.

Sorgente, D., Frignani, M., Langone, L. and Ravaioli, M., 1999. Chronology of marine sediments: interpretation of activity-depth profiles of ${ }^{210} \mathrm{~Pb}$ and other radioactive tracers, Consiglio Nazionale delle Ricerche. Instituto per la Geologia Marina, Bologna.

Spooner, I.S. et al., 2003. The impact of air mass circulation dynamics on Late Holocene paleoclimate in northwestern North America. Quaternary International, 108: 7783.

SPSS, 2005. SPSS 11 for Mac OS X. SPSS Inc., Chicago, IL, USA.

Stein, S.F.N.v., 1859. Uber die ihm aus eigener Untersuchung bekannt gewordenen Suswasser-Rhizopoden. Konigliche Bohmishce Gesellschaft der Wissenchaften Abhandlungen, 10(5): 41-43.

Stuiver, M., Reimer, P.J. and Reimer, R., 2005. CALIB manual. http://radiocarbon.pa.qub.ac.uk/calib/manual/index.html.

Syvitski, J.P.M., 1989. On the deposition of sediment within glacier-influenced fjords: oceanographic controls. Marine Geology, 85: 301-329.

Telford, R.J., Heegaard, E. and Birks, H.J.B., 2004. All age-depth models are wrong: but how badly? Quaternary Science Reviews, 23: 1-5.

ter Braak, C.J.F. and Prentice, I.C., 1988. Partial canonical correspondence analysis. Advances in Ecological Research, 18: 271-317. 
ter Braak, C.J.F. and Smilauer, P., 1998a. CANOCO 4. Microcomputer Power, Ithaca, NY, USA.

ter Braak, C.J.F. and Smilauer, P., 1998b. CANOCO reference manual and user's guide to Canoco for Windows: Software for canonical community ordination (version 4). Microcomputer Power, Ithaca, NY, USA, $352 \mathrm{pp}$.

Terquem, O., 1876. Essai sur le classement des animaux qui vivent sur la plage et dans les environs de Dunkerque, pt. 1. Mémoires de la Société Dunkerquoise pour l'Encouragement des Sciences, des Lettres et des Arts (1874-1876), 19: 405-457.

Thalman, H.E., 1952. Bibliography and index to new genera, species and varieties of foraminifera for the year 1951. Journal of Paleontology, 26: 953-992.

Thomson, R.E., 1981. Oceanography of the British Columbia coast. Canadian Special Publication of Fisheries and Aquatic Sciences, 56(291).

Todd, R., 1947. Subfamily Uvigerininae. In: J.A. Cushman and I. McCulloch (Editors), The species of Bulimina and related genera in the collections of teh Allan Hancock Foundation. University of Southern California Publication, Allan Hancock Pacific Expedition, Los Angeles, California, USA, pp. 288.

Todd, R. and Low, D., 1967. Recent foraminifera from the Gulf of Alaska and shoutheastern Alaska. Geological Survey Professional Paper, 573-A, Washington, USA, $46 \mathrm{pp}$.

Trenberth, K.E. and Hurrel, J.W., 1995. Decadal climate variations in the Pacific. In: N.R. Council (Editor), Natural variability on decade-to-century time scales, pp. 472-482. 
Vázquez Riveiros, N. et al., 2006. Modern distribution of saltmarsh foraminifera and thecamoebians in the Seymour-Belize Inlet Complex, British Columbia, Canada. Marine Geology, submitted.

Villanueva Guimerans, P. and Cervera Currado, J.L., 1999. Distribution of Planorbulinacea (benthic foraminifera) assemblages in surface sediments on the northern margin of the Gulf of Cadiz. Boletin del Instituto Espanol de Oceanografia, 15(1-4): 181-190.

Voloshinova, N.A., 1952. In: N.A. Voloshinova and L.G. Dain (Editors), Iskopaemye Foraminifery SSRS. Nonionidy, Kassidulinidy i Khilostomellidy (Fossil foraminifera of the USSR. Nonionidae, Cassidulinidae and Chilostomellidae. Vsesoyuznogo Neftyanogo Nauchnoissledovatel'skogo Geologo-razvedochnogo Instituta (VNIGRI), pp. 1-151.

Voloshinova, N.A., 1958. O novy sistematike Nonionid (On new systematics of the Nonionidae). Trudy vsesoyuznogo neftyanogo nauchnoissledovatel'skogo geologorazvedochnogo instituta (VNIGRI), 115: 117-191.

von Siebold, C.T.E., 1864. Wirbellose Thiere: part 1. In: C.T.E. von Siebold and H. von Stannius (Editors), Lehrbuch del Vergleichenden Anatomie, pp. 679.

Walker, D.A. and Jacob, E., 1789. In: F. Kanmacher (Editor), Adam's essays on the microscope; the second edition with considerable additions and improvements. Dillon \& Keating, London.

Walker, G. and Jacob, E., 1784. In: F. Kanmacher (Editor), Adams' essays on the microscope. Dillon and Keating, London, UK, pp. 642.

Wallach, D. and Goffinet, B., 1989. Mean squared error of prediction as a criterion for evaluating and comparing system models. Ecological Modelling, 44: 299-306. 
Ware, D.M. and McFarlane, G.A., 1989. Fisheries production domains in the Northeast Pacific Ocean. In: R.J. Beamish and G.A. McFarlane (Editors), Effects of ocean variability on recruitment and an evaluation of parameters used in stock assessment models. Canadian Special Publication of Fisheries and Aquatic Sciences, pp. 359-379.

Ware, D.M. and Thomson, R.E., 2000. Interannual to multidecadal timescale climate variations in the Northeast Pacific. Journal of Climate, 13: 3209-3220.

Wiesner, H., 1931. Die Foraminiferen der deutschen Südpolar-Expetidion 1901-1903. In: E.v. Drygalski (Editor), Deustche Süudpolar-Expedition 1901-1903. de Gruyter, Berlin.

Wigston, A.P., 2006. Late Holocene climate change of Frederick Sound, British Columbia, Canada, Carleton University, Ottawa, ON, Canada, 225 pp.

Williamson, W.C., 1848. On the Recent British species of the genus Lagena. Annals and Magazine of Natural History, series 2, 1: 1-20.

Williamson, W.C., 1858. On the recent foraminifera of Great Britain. Ray Society, London: 34. 


\section{APPENDIX A}

Fractional abundance of all foraminiferal taxa from all samples. Species indicated with * represent the ones present in statistically significant numbers. 


\begin{tabular}{|c|c|c|c|c|c|c|c|c|c|c|c|c|c|c|}
\hline & $\mathrm{BE}]$ & BE2 & BE3 & BE5 & BE7 & ALS1 & ALS2 & ALS3 & $\begin{array}{l}\mathrm{FCO} 4- \\
2^{\wedge} 10\end{array}$ & $\begin{array}{l}\mathrm{F} C 04- \\
11^{\wedge} 18\end{array}$ & $\begin{array}{l}\mathrm{FC} 04- \\
19^{\wedge} 26\end{array}$ & $\begin{array}{l}\mathrm{FC} 04- \\
27+29\end{array}$ & $\begin{array}{l}\text { FCO4- } \\
30+3 !\end{array}$ & FC04-32 \\
\hline Angulogerina fluens & 0.01 & & & & & & & & 0.05 & & & & & \\
\hline \multicolumn{15}{|l|}{ Ammodiscus gullmarensis** } \\
\hline Astronomion gallowayi* & 0.02 & & & & & & & & & & & & & \\
\hline Bolivina decussata & 0.00 & 0.01 & & & & & & & & & & & & \\
\hline Botivina mimula ${ }^{*}$ & 0.01 & 0.03 & & & & & & & & & 0.01 & & & \\
\hline Bolivinellina pacifica* ${ }^{*}$ & 0.03 & 0.01 & & & & & & & & & & & & \\
\hline Botuloides paucilocultus & 0.00 & & & & & & & & & & & & & \\
\hline Buccella frigida* & 0.12 & 0.14 & & & & & 0.33 & & 0.11 & 0.15 & 0.53 & 0.36 & 0.40 & 0.47 \\
\hline Buccella hamnai & & & & & & & & & & 0.01 & & 0.03 & 0.01 & \\
\hline Buccella imusitata & 0.01 & 0.01 & & & & & & & & & & & & \\
\hline Buccella tenerrima* & 0.01 & & & & & & & & & & & & & \\
\hline Buccella depressa & 0.00 & & & & & & & & & & & & & \\
\hline Buliminella elegantissima* & 0.01 & 0.03 & & & & & 0.12 & & & & & & & \\
\hline \multicolumn{15}{|l|}{ Cassidulina sp. } \\
\hline Cassidulima crassa* & 0.00 & 0.02 & 0.05 & & & & & & 0.05 & 0.16 & & & 0.02 & 0.05 \\
\hline Cribroelphidium excavatum* & & 0.18 & 0.02 & & & & & & & & 0.01 & & & \\
\hline C. excavatum $f$. magna* & & & & & & & & & & 0.09 & 0.09 & 0.12 & 0.17 & 0.07 \\
\hline C. excavatum f. clavata* & 0.02 & & & 0.00 & & & & & 0.06 & 0.04 & & 0.11 & 0.14 & 0.27 \\
\hline C. excavatum f. excavata* ${ }^{*}$ & 0.08 & & & & & & & & & & 0.03 & & 0.01 & \\
\hline C. excavatum f. selseyensis* & 0.00 & & & & & & & & & & & & & \\
\hline C. excavatum f. lidoensis & 0.00 & & & & & & & & & & & & & \\
\hline Cribroelphidium foraminosum* & 0.01 & & & & & & & & & & 0.01 & 0.08 & 0.12 & 0.05 \\
\hline Cribroelphidium hallandense* & 0.03 & & & & & & & & & & & & & \\
\hline Cribroelphidium magellanicum* & 0.03 & 0.01 & & & & & & & & & & & & \\
\hline Cribroelphidium microgramulosum ${ }^{*}$ & 0.07 & & & & & & & & & & & & & \\
\hline Cribrastomoides sp. $A^{*}$ & & & & 0.02 & & 0.02 & & 0.01 & & & & & & \\
\hline Cribrostomoides crassimargo ${ }^{*}$ & & & & & & & 0.05 & 0.03 & & & & & & \\
\hline Cribrostomoides jeffreysiti* & 0.00 & & 0.03 & 0.14 & 0.01 & 0.03 & & 0.02 & & & 0.01 & & & \\
\hline Cribrostomoides subglobosum * & & 0.01 & 0.07 & 0.11 & 0.01 & 0.21 & 0.14 & 0.03 & 0.02 & & & 0.01 & 0.01 & \\
\hline \multicolumn{15}{|l|}{ Cribrostomoides wiesneri* } \\
\hline Dyocibicides biserialis & 0.01 & & & & & & & & & & & & & \\
\hline Eggerella advena* & 0.00 & 0.07 & 0.14 & 0.07 & 0.05 & 0.32 & 0.15 & 0.19 & 0.03 & 0.01 & 0.03 & 0.01 & & \\
\hline Eggerella whatever* & & & & 0.02 & & & & 0.26 & 0.08 & & 0.01 & & & \\
\hline Elphidiella hannai* & 0.03 & & & & & & & & & 0.01 & 0.01 & 0.04 & & \\
\hline Epistominella virreq* & 0.01 & 0.02 & & & & & & & 0.03 & 0.01 & & 0.01 & 0.02 & \\
\hline Eutvigerina aculeata & & & 0.02 & & & & & & & 0.03 & & & & \\
\hline Eutuvigerina peregrina* & 0.00 & & 0.03 & 0.00 & & & & & 0.03 & 0.01 & & 0.03 & 0.03 & 0.03 \\
\hline Favulina epibathra* & 0.01 & & & & & & & & & & & & & \\
\hline Favulina melo & 0.00 & & & & & & & & & & & & & \\
\hline Fissurina cucurbitasema & 0.00 & & & & & & & & & & & & & \\
\hline Fissurma eburnea* & 0.01 & & & & & & & & & & & & & \\
\hline \multicolumn{15}{|l|}{ Fissurina Incida } \\
\hline Fissurina vitreola & 0.00 & & & & & & & & & & & & 0.01 & \\
\hline Gavelinopsis campanulata & 0.00 & & & & & & & & & & & & & \\
\hline Gaudryina arenaria & 0.00 & 0.01 & & & & & & & & & & & & \\
\hline Haplophragmoides brady* & & 0.02 & 0.27 & 0.30 & 0.38 & & & & 0.21 & & 0.01 & & & \\
\hline Homatohedra apiopleura & 0.00 & & & & & & & & & & & & & \\
\hline Homalohedra borealis & 0.00 & & & & & & & & & & & & & \\
\hline Homalohedra guntherii & 0.01 & & & & & & & & & & & & & \\
\hline Hyalinonetrion dentaliforme & 0.00 & & & & & & & & & & & & & \\
\hline Islandiella $s p$ & 0.01 & & & & & & & & & & & & & \\
\hline Islandiella helenae* & 0.04 & & & & & & & & & & & & & \\
\hline Lagena sp. & & 0.01 & & & & & & & & & & & & \\
\hline \multicolumn{15}{|l|}{ Lagena meridionalis } \\
\hline Lagena laevis & & 0.01 & & & & & & & & & & & & \\
\hline \multicolumn{15}{|l|}{ Lagena parri } \\
\hline Lagena semilineata & 0.00 & & & & & & & & & & & & & \\
\hline Lanyngosigma trilocularis & 0.01 & & & & & & & & & & & & & \\
\hline Lobatula fletcher $; *$ & 0.11 & 0.10 & 0.02 & & & & & & & 0.01 & & 0.01 & 0.01 & 0.03 \\
\hline Lobatula lobatula* & 0.07 & & & & & & & & & & & & & \\
\hline Lobatula mckamai** & 0.12 & & & & & & & & 0.02 & 0.01 & 0.03 & & & \\
\hline
\end{tabular}




\begin{tabular}{|c|c|c|c|c|c|c|c|c|c|c|c|c|c|c|}
\hline & $\mathrm{BE} 1$ & BE2 & $\mathrm{BE} 3$ & BES & BE7 & ALS1 & ALS2 & ALS3 & $\begin{array}{c}\mathrm{FCO}_{4}- \\
2^{\wedge} 10\end{array}$ & $\begin{array}{l}\text { FCO4- } \\
11^{\wedge} 18\end{array}$ & $\begin{array}{l}\mathrm{FCO} 4- \\
19^{\wedge} 26\end{array}$ & $\begin{array}{l}\mathrm{FCO4}- \\
27+29\end{array}$ & $\begin{array}{l}\mathrm{FCO4} \\
30+31\end{array}$ & $\mathrm{FC} 04-32$ \\
\hline Miliammina fusca ${ }^{*}$ & & & & & & & & 0.09 & & & & & & \\
\hline \multicolumn{15}{|l|}{ Miliammina sp. } \\
\hline \multicolumn{15}{|l|}{ Neouvigerina proboscidea* } \\
\hline Nonionella digitata & 0.00 & & & & & & & & & & & & & \\
\hline Nonionella stella* & 0.01 & & & & & & & & 0.05 & & & & & \\
\hline Nonionella cf. turgida & 0.00 & & & & & & & & & & & & & \\
\hline Nonionellina labradorica* & 0.01 & 0.13 & 0.02 & & & & & & 0.17 & 0.37 & 0.14 & 0.14 & 0.04 & 0,02 \\
\hline Palliolatella fragens & 0.00 & & & & & & & & & & & & & \\
\hline Palliolatella immemora & 0.00 & & & & & & & & & & & & & \\
\hline Parafissurina semicarinata & & & & & & & & & & & & & 0.01 & \\
\hline Portatrochammina bipolaris* & 0.00 & 0.03 & 0.20 & 0.11 & 0.21 & 0.03 & 0.00 & 0.04 & & & 0.01 & 0.01 & & \\
\hline Procerolagena cf. amphora & & 0.01 & & & & & & & & & & & & \\
\hline Procerolagena gracilis & 0.00 & & & & & & & & & & & & & \\
\hline Procerolagena mollis & 0.00 & & & & & & & & & & & & & \\
\hline \multicolumn{15}{|l|}{ Procerolagena wiesneri } \\
\hline Protoglobulimina pupoides* & 0.01 & 0.01 & & & & & & & & & 0.01 & & & \\
\hline Psendononion basispinata & 0.00 & & & & & & & & & & & & & \\
\hline Pygmaeoseistron hispidulum & & & 0.02 & & & & & & & & & & & \\
\hline Quinqueloculina sp. & & & & & & & & & & & 0.03 & & & \\
\hline Rosalina columbiensis* & 0.02 & & & & & & & & & & & & & \\
\hline Recurvoides turbinatus* & & & & 0.03 & & 0.12 & 0.10 & 0.02 & & & 0.01 & 0.01 & 0.01 & \\
\hline \multicolumn{15}{|l|}{ Reophax catella } \\
\hline \multicolumn{15}{|l|}{ Reophax cylindrictss } \\
\hline \multicolumn{15}{|l|}{ Reophax gracilis } \\
\hline \multicolumn{15}{|l|}{ Reophax scottii } \\
\hline \multicolumn{15}{|l|}{ Saccammina atlantica } \\
\hline \multicolumn{15}{|l|}{ Saccammina sphaerica } \\
\hline Spiroplectammina biformis* & & 0.01 & 0.02 & 0.02 & 0.01 & 0.22 & 0.11 & 0.11 & & & & & & \\
\hline Stainforthia feylingi* & 0.01 & 0.01 & & & & & & & & & & & 0.01 & \\
\hline Textularia earlandi* & & & & 0.01 & 0.01 & & & & & & & & & \\
\hline Trochammina sp. & & 0.02 & & & & & & & & & & & & \\
\hline Trochammina charlottensis* & 0.00 & 0.03 & & 0.02 & 0.01 & 0.02 & & 0.04 & 0.02 & & & & & \\
\hline Trochammina discorbis* & & 0.06 & 0.08 & 0.11 & 0.24 & & & & 0.06 & & 0.01 & 0.01 & & \\
\hline Trochammina cf. globigeriniformis* & & 0.05 & 0.02 & 0.02 & & & & & & & & & & \\
\hline \multicolumn{15}{|l|}{ Trochammina grisea } \\
\hline \multicolumn{15}{|l|}{ Trochammina squamata } \\
\hline Trochammina nana* & & & & & & & & 0.02 & & & & & & \\
\hline Trochammina nitida & 0.00 & & & & & & & & & & & & & \\
\hline Trochammina ochracea & 0.00 & 0.02 & & 0.00 & & & & & & & & & & 0.02 \\
\hline Trochammina pacifica & 0.00 & & & & & & & 0.01 & 0.02 & 0.01 & & & & \\
\hline Trochammina rotaliformis & 0.01 & & & & & & & & & & & & & \\
\hline Planktonic sp.* & 0.01 & & & & & & & & & 0.04 & & & & \\
\hline Thecamoebiais* & & 0.01 & & 0.02 & 0.09 & 0.02 & & 0.13 & & & & & & \\
\hline Total Counts & 528 & 193 & 59 & 577 & 117 & 98 & 226 & 161 & 63 & 68 & 78 & 91 & 112 & 60 \\
\hline
\end{tabular}




\begin{tabular}{|c|c|c|c|c|c|c|c|c|c|c|c|c|c|c|}
\hline & $\begin{array}{l}\mathrm{FCO} 4- \\
33^{\wedge} 35\end{array}$ & FC04-36 & $\mathrm{F} C 04-37$ & $\begin{array}{l}\text { FCO4- } \\
38+39\end{array}$ & $\begin{array}{l}F C 04 \\
40+41\end{array}$ & $\mathrm{FCO} 4-42$ & FCO4-43 & $\begin{array}{l}\mathrm{FCO} 4- \\
44+45\end{array}$ & FCO4-46 & FC04-47 & $\begin{array}{l}\mathrm{FC} 04- \\
48+49\end{array}$ & $\begin{array}{l}\mathrm{FCO} 4- \\
50+51\end{array}$ & FC04-52 & $\mathrm{FC} 04-53$ \\
\hline \multicolumn{15}{|l|}{ Angulogerina fluens } \\
\hline \multicolumn{15}{|l|}{ Ammodiscus gullmarensis* } \\
\hline \multicolumn{15}{|l|}{ Astrononion gallowayi* } \\
\hline \multicolumn{15}{|l|}{ Bolivina decussata } \\
\hline Bolivina minuta* & & 0.02 & 0.02 & & 0.01 & & & 0.01 & & & 0.01 & 0.02 & 0.02 & 0.01 \\
\hline \multicolumn{15}{|l|}{ Bolivinellina pacifica* } \\
\hline \multicolumn{15}{|l|}{ Botuloides pauciloculus } \\
\hline Buccella frigida* & 0.42 & 0.16 & 0.29 & 0.30 & 0.39 & 0.39 & 0.38 & 0.34 & 0.31 & 0.29 & 0.33 & 0.24 & 0.24 & 0.16 \\
\hline \multicolumn{15}{|l|}{ Buccella hamai } \\
\hline Buccella imsitata & & & & & 0.03 & & & & & & 0.01 & & & \\
\hline Buccella tenerrima* & & & & 0.07 & & 0.02 & & & 0.06 & & & & 0.02 & 0.04 \\
\hline Buccella depressa & & & & 0.03 & & & & & & & & & & \\
\hline \multicolumn{15}{|l|}{ Buliminella elegantissima* } \\
\hline Cassidutina sp. & & & & & & & & 0.03 & & & & & & \\
\hline Cassidulina crassa* & & 0.07 & 0.09 & 0.02 & 0.01 & & & & & 0.06 & 0.03 & 0.02 & 0.05 & 0.02 \\
\hline Cribroelphidium excavatum ${ }^{*}$ & 0.04 & & & & & & & 0.01 & & & & & & \\
\hline C. excavatum $f$. magna $^{*}$ & 0.13 & 0.26 & 0.23 & 0.19 & 0.25 & 0.30 & 0.17 & 0.19 & 0.26 & 0.18 & 0.20 & 0.44 & 0.29 & 0.22 \\
\hline C. excavatum f. clovata* & 0.19 & 0.28 & 0.17 & 0.10 & 0.12 & 0.11 & 0.21 & 0.18 & 0.16 & 0.16 & 0.10 & 0.08 & 0.20 & 0.20 \\
\hline C. excavatum f. excavata* & & 0.03 & 0.05 & 0.05 & 0.01 & & 0.09 & & & & 0.03 & & 0.01 & 0.05 \\
\hline C. excavatum f. selseyensis* & & & 0.04 & 0.09 & 0.01 & & & 0.03 & & & & & & \\
\hline C. excavatum f. lidoensis & & & & & & & & & & & & & & 0.01 \\
\hline Cribroelphidium foraminostum ${ }^{*}$ & 0.07 & 0.07 & & & 0.02 & 0.05 & & 0.07 & 0.03 & 0.08 & & & 0.02 & 0.06 \\
\hline \multicolumn{15}{|l|}{ Cribroelphiditum hallandense* } \\
\hline \multicolumn{15}{|l|}{ Cribroelphidium magellanicum* } \\
\hline \multicolumn{15}{|l|}{ Cribroelphidium microgranulosum ${ }^{*}$} \\
\hline Cribrostomoides sp. $A^{*}$ & & & & & & & & & & & & & & \\
\hline Cribrostomoides crassimargo* & & & & & & & & & & & & & & \\
\hline Cribrostomoides jeffreysii* & & & & 0.01 & & & & & & 0.02 & & & & \\
\hline Cribrostomoides subglobosum ${ }^{*}$ & & & & & 0.01 & & & 0.01 & & & 0.03 & & & 0.01 \\
\hline Cribrostomoides wiesneri* & & & & & & & & & & & & & & \\
\hline Dyocibicides biserialis & & & & & & & & & & & & & & \\
\hline Eggerella advena* & & & & & & & & & & & & & & \\
\hline Eggerella whatever* & & & & & & & & & & & & & & \\
\hline Elphidiella hannai* & & & & & 0.02 & & & & & 0.02 & & & & \\
\hline Epistominella vitrea* & 0.01 & 0.02 & & 0.05 & & 0.07 & & & 0.03 & 0.04 & 0.03 & 0.03 & 0.01 & 0.04 \\
\hline Etuvigerina aculeata & 0.01 & & & 0.01 & & & & & & & & & 0.01 & \\
\hline Eunvigerina peregrina* & 0.02 & 0.02 & 0.01 & 0.02 & 0.01 & & & & & & & 0.02 & 0.02 & 0.02 \\
\hline Favulina epibathra* & & & & & & & & & & & & & 0.01 & \\
\hline Favulina melo & & & & & & & & & & & & & & \\
\hline Fissurina cucurbitasema & & & & & & & & & & & & & & \\
\hline Fissurina eburnea $*$ & & & & & & & & & & & & & & \\
\hline Fissurina lucida & & & & & & & & & & & & & & \\
\hline Fissurina vitreola & & & & & 0.01 & & & & & & & & & \\
\hline Govelinopsis campanulata & & & & & & & & & & & & & & \\
\hline Gaudryina arenaria & & & & & & & & & & & & & & \\
\hline Haplophragmoides brady* & & & & & 0.01 & & & & 0.03 & 0.02 & & & & \\
\hline Homalohedra apiopleura & & & & & & & & & & & & & & \\
\hline Homalohedra borealis & & & & & & & & & & & & & & \\
\hline Homalohedra guntherii & & & & & & & & & & & & & & \\
\hline Hyalinonetrion dentaliforme & & & & & & & & & & & & & & \\
\hline Islandiella sp. & & & & & & & & & & & & & & \\
\hline Islandiella helenae* & & & & & & & & & & & & & & \\
\hline Lagenasp. & & 0.02 & & & & & & & & & & & & \\
\hline Lagena meridionalis' & & 0.02 & & & & & & & & & & & & \\
\hline Lagena laevis & & & & & & & & & & & & & & \\
\hline Lagena parri & & & & & 0.01 & & & & & & & & & \\
\hline Lagena semilineata & & & & & & & & & & & & & & \\
\hline Laryngosigma trilocwlaris & & & & & & & & & & & & & & \\
\hline Lobatula fletcheri* & 0.01 & 0.02 & 0.04 & 0.02 & & 0.02 & & 0.01 & 0.01 & & 0.03 & & 0.04 & 0.04 \\
\hline Lobatula lobatula* & & & & & & & & & & & & & & \\
\hline Lobatula mckannai* & & & & 0.03 & & & & & & & 0.01 & 0.08 & & 0.02 \\
\hline
\end{tabular}




\begin{tabular}{|c|c|c|c|c|c|c|c|c|c|c|c|c|c|c|}
\hline & $\begin{array}{l}\mathrm{FC} 04- \\
33^{\wedge} 35\end{array}$ & FC04-36 & FCO4-37 & $\begin{array}{l}\mathrm{FC} 04- \\
38+39\end{array}$ & $\begin{array}{l}\mathrm{FCO} 4- \\
40+41\end{array}$ & $\mathrm{FCO} 4-42$ & $\mathrm{FC} 04-43$ & $\begin{array}{l}\text { FCO4- } \\
44+45\end{array}$ & FC04-46 & $\mathrm{FC} 04-47$ & $\begin{array}{l}\mathrm{FC} 04- \\
48+49\end{array}$ & $\begin{array}{l}\mathrm{FCO} 4- \\
50+51\end{array}$ & FC04-52 & $\mathrm{FC} 04-53$ \\
\hline \multicolumn{15}{|l|}{ Miliammina fusca ${ }^{*}$} \\
\hline \multicolumn{15}{|l|}{ Miliammina sp. } \\
\hline Neouvigerima proboscidea* & & & & & & & 0.02 & & & & & & 0.04 & 0.01 \\
\hline \multicolumn{15}{|l|}{ Nonionella digitata } \\
\hline Nonionella stella* ${ }^{*}$ & & & 0.03 & & & & & & & & $0.0 \mathrm{I}$ & & & \\
\hline \multicolumn{15}{|l|}{ Nonionella cf. turgida } \\
\hline $\begin{array}{l}\text { Nonionellina Labradorica } \\
\text { Palliolatella fragens }\end{array}$ & \multicolumn{14}{|c|}{ Palliolatella fragens } \\
\hline Palliolatella immemora & 0.01 & & & & & & & & & & & & & \\
\hline Parafisstrina semicarinata & & & 0.01 & & 0.01 & & & & & & & & & 0.00 \\
\hline Portatrochammina bipolaris* & & & & & & & & & & & & 0.02 & & \\
\hline Procerolagena cf. amphora & & & & & & & & & & & & & & \\
\hline \multicolumn{15}{|l|}{ Procerolagena gracilis } \\
\hline \multicolumn{15}{|l|}{ Procerolagena mollis } \\
\hline \multicolumn{15}{|l|}{ Procerolagena wiesneri } \\
\hline \multicolumn{15}{|l|}{ Protoglobulimina pupoides* } \\
\hline \multicolumn{15}{|l|}{ Pseudononion basispinata } \\
\hline \multicolumn{15}{|l|}{ Pygmaeoseistron hispidultum } \\
\hline Quinqueloculina sp. & & & & & 0.01 & & & & & & & & & \\
\hline \multicolumn{15}{|l|}{ Rosalina columbiensis ${ }^{*}$} \\
\hline Recurvoides turbinatus* ${ }^{*}$ & & & & & & & & & & 0.02 & & & & \\
\hline \multicolumn{15}{|l|}{ Reophax catella } \\
\hline \multicolumn{15}{|l|}{ Reophax cylindricus } \\
\hline \multicolumn{15}{|l|}{ Reophax gracilis } \\
\hline \multicolumn{15}{|l|}{ Reophax scottii } \\
\hline \multicolumn{15}{|l|}{ Saccammina atlantica } \\
\hline \multicolumn{15}{|l|}{ Saccammina sphaerica } \\
\hline \multicolumn{15}{|l|}{ Spiroplectammina biformis* } \\
\hline Stainforthia feylingi* & & & 0.01 & & & & & & & & & & & \\
\hline \multicolumn{15}{|l|}{ Textularia earlandi* } \\
\hline Trochammina sp. & & & & & & & & 0.03 & 0.01 & & 0.01 & & & \\
\hline Trochammina charlottensis ${ }^{*}$ & & & 0.01 & & & & & & & & & & & \\
\hline Trochammina discorbis* & & & & & & & & & 0.01 & & 0.01 & & & \\
\hline Trochammina of. globigerimformis & & & & & & & & & & & & & & \\
\hline Trochammina grisea & & & & & & & & & & & & & & \\
\hline Trochammina squamata & & & & & & & & & & & & & & \\
\hline Trochammina nana* & & & & & 0.01 & & & & & & & & & \\
\hline Trochammina nitida & & & & & & & & & & & & & & \\
\hline Trochammina ochracea & & & & & & & & & & & & & & \\
\hline Trochammina pacifica & & & & & & & & & & & 0.01 & & & \\
\hline Trochammina rotatiformis & & & & & & & & & & & & & & \\
\hline Planktomic sp.* & & & & & & & & & & & & & & \\
\hline Thecamoebians* & & & & & & & & & & & & & & \\
\hline Total Counts & 100 & 61 & 109 & 110 & 134 & 44 & 47 & 68 & 70 & 49 & 70 & 59 & 165 & 224 \\
\hline
\end{tabular}


FC04-54 FC04-55 FC04-56 FC04-57 FC04-58 FC04-59 FC04-61 FC04-62 FC04-63 FC04-64 FC04-65 FC04-66 FC04-67 FC04-68

\begin{tabular}{|c|c|c|c|c|c|c|c|c|c|c|c|c|c|c|}
\hline Angulogerina fluens & & & & & & & & & & & & & & \\
\hline Ammodiscus gullmarensis* & & & & & & & & & & & & 0.00 & 0.00 & \\
\hline \multicolumn{15}{|l|}{ Astrononion gallowayi* } \\
\hline \multicolumn{15}{|l|}{ Bolivina decussata } \\
\hline Bolivina minuta* & 0.03 & 0.08 & 0.02 & 0.02 & & 0.01 & 0.06 & 0.03 & 0.03 & 0.02 & 0.01 & 0.02 & 0.02 & 0.02 \\
\hline \multicolumn{15}{|l|}{ Bolivinellina pacifica* } \\
\hline Botuloides paucilocuhus & & & & & & & & & & & 0.01 & & & \\
\hline Buccella frigida* & 0.18 & 0.25 & 0.11 & 0.19 & 0.26 & 0.23 & 0.06 & 0.16 & 0.16 & 0.18 & 0.01 & 0.06 & 0.05 & 0.05 \\
\hline \multicolumn{15}{|l|}{ Buccella hamai } \\
\hline \multicolumn{15}{|l|}{ Buccella intsitata } \\
\hline Buccella tenerrima* & 0.05 & 0.03 & 0.02 & & 0.07 & 0.01 & 0.05 & 0.02 & 0.02 & 0.02 & & & 0.01 & 0.00 \\
\hline \multicolumn{15}{|l|}{ Buccella depressa } \\
\hline Buliminella elegantissima* & & & & & & & & & 0.02 & 0.03 & & & & \\
\hline \multicolumn{15}{|l|}{ Cassidulina sp. } \\
\hline Cassidulina crassa* & 0.01 & 0.03 & 0.02 & 0.11 & 0.04 & 0.03 & 0.05 & 0.04 & 0.03 & 0.03 & 0.07 & 0.02 & 0.05 & 0.05 \\
\hline \multicolumn{15}{|l|}{ Cribroelphidium excavatum* } \\
\hline C. excanatum f magna* & 0.24 & 0.20 & 0.16 & 0.14 & 0.24 & 0.30 & 0.24 & 0.26 & 0.28 & 0.35 & 0.05 & 0.04 & & 0.03 \\
\hline C. excavaum $f$. clavata* & 0.10 & 0.13 & 0.23 & 0.19 & & 0.15 & 0.28 & 0.26 & 0.22 & & 0.04 & 0.14 & 0.13 & 0.07 \\
\hline C. excavatum f. excavata* & & & 0.02 & & 0.07 & & 0.09 & & 0.09 & 0.09 & 0.06 & 0.02 & & 0.00 \\
\hline \multicolumn{15}{|l|}{ C. excavatumf. selseyensis* } \\
\hline C. excovatum f. lidoensis & & & & & & & & 0.01 & 0.01 & 0.03 & 0.00 & & & \\
\hline Cribroelphidium foraminosum * & 0.09 & & 0.09 & 0.06 & 0.04 & 0.01 & & 0.04 & 0.04 & 0.02 & 0.01 & 0.01 & & 0.01 \\
\hline \multicolumn{15}{|l|}{ Cribroelphidium hallandense* } \\
\hline \multicolumn{15}{|l|}{ Cribroelphidium magellanicum* } \\
\hline Cribroelphidium microgranulosum & & & & & & & & & & & & & & \\
\hline Cribrastomoides sp. $A^{*}$ & & & & & & & & & & & 0.00 & & & \\
\hline Cribrostomoides crassimargo* & & & & & & & & & & & & 0.01 & & \\
\hline Cribrostomoides jeffreysii ${ }^{*}$ & & & & & & & & & & & & & & \\
\hline Cribrostomoides subglobostum* & & & & & & & & & & 0.02 & & 0.01 & 0.01 & 0.00 \\
\hline Cribrostomoides wiesneri* & & & & & & & & & & & & & & \\
\hline Dyocibicides biserialis & & & & & & & & & & & & & & \\
\hline Eggerella advena* & & & & & & 0.02 & & & & & 0.00 & & 0.00 & 0.00 \\
\hline Eggerella whatever* & & & & & & & & & & & & & & 0.00 \\
\hline Elphidiella hannai* & & & & & & & & 0.01 & & & & & & \\
\hline Epistominella vitrea* & 0.05 & 0.03 & 0.07 & 0.05 & & 0.01 & 0.06 & 0.03 & 0,03 & 0.03 & 0.02 & 0.02 & 0.03 & 0.02 \\
\hline Ezuvigerina aculeata & & & & & & 0.02 & & & & & & 0.00 & 0.00 & \\
\hline Ennvigerina peregrina* & 0.03 & 0.05 & & 0.02 & 0.02 & 0.02 & & 0.01 & 0.02 & 0.03 & & & & \\
\hline Favulina epibathra* & & & & & & & & & & & & & & \\
\hline Favulina melo & & & & & & & & & & & & & & \\
\hline Fissurma cucurbitasema & & & & & & & & & & & 0.00 & & 0.00 & 0.00 \\
\hline Fissurina eburnea* & & & & & & & & & & & & & & \\
\hline Fissurina lucida & & & & & 0.02 & 0.02 & & & & & & & 0.00 & \\
\hline Fissurina vitreola & & & & & 0.02 & & & & & & & & & \\
\hline Gavelinopsis campanulata & & & & & & & & & & & & & & \\
\hline Gaudryina arenaria & & & & & & & & & & & & & & \\
\hline Haplophragmoides brady* & 0.01 & & & & & 0.02 & & & & & 0.10 & 0.16 & 0.10 & 0.08 \\
\hline Homalohedra apiopleura & & & & & & & & & & & & & & \\
\hline Homalohedra borealis & & & & & & & & & & & & & & \\
\hline Homalohedra guntherii & & & & & & & & & & & & & & \\
\hline Hyalinonetrion dentaliforme & & & & & & & & & & & & & & \\
\hline Islandiella sp. & & & & & & & & & & & & & & \\
\hline Islandiella helenae* & & & & & & & & & & & & & & \\
\hline Lagena sp. & & & & & & & & & & & & & & \\
\hline Lagena meridionalis & & & & & & & & & & & & & 0.00 & 0.00 \\
\hline Lagena laevis & & & & & & & & & & & & & & \\
\hline Lagena parri & & & & & & & & & & & & & & \\
\hline Lagena semilineata & & & & & & & & & & & & & & \\
\hline Laryngosigma triloctharis & & & & & & & & & & & & & & \\
\hline Lobatula fletcheri* & 0.04 & 0.05 & & 0.02 & & 0.02 & 0.01 & 0.03 & & & 0.00 & & 0.00 & 0.01 \\
\hline Lobatula lobatula* & & & & & & & & & & & & & & \\
\hline Lobatula mckannai* & & & & & & & & & & & 0.0 & & & \\
\hline
\end{tabular}


FC04-54 FC04-55 FC04-56 FC04-57 FC04-58 FC04-59 FC04-61 FC04-62 FC04-63 FC04-64 FC04-65 FC04-66 FC04-67 FC04-68

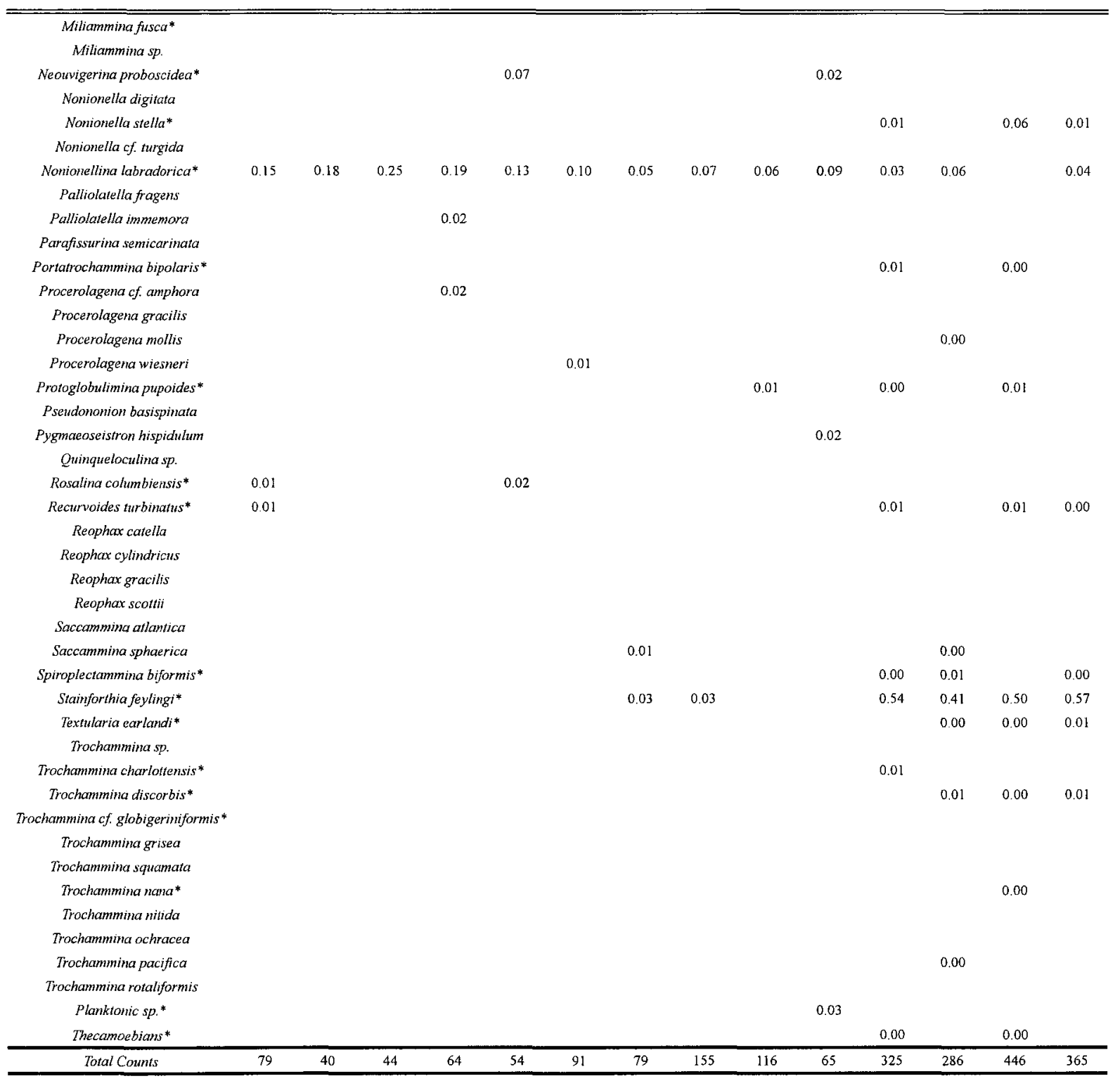




\begin{tabular}{|c|c|c|c|c|c|c|c|c|c|c|c|c|c|c|}
\hline & $\mathrm{FC} 04-70$ & $\mathrm{FCO} 4-73$ & FC04-75 & FC04-76 & $\mathrm{FC} 04-77$ & FC04-78 & $\mathrm{FC} 04-79$ & $\mathrm{FC} 04-80$ & $\begin{array}{l}\mathrm{FC} 04- \\
86+87\end{array}$ & $\begin{array}{l}\mathrm{FC} 04- \\
88+89\end{array}$ & $\begin{array}{l}\text { FCOA- } \\
90^{\wedge} 93\end{array}$ & $\begin{array}{l}\mathrm{FCOA-} \\
94^{\wedge} 97\end{array}$ & $\begin{array}{c}\mathrm{FC} 04- \\
109\end{array}$ & $\begin{array}{c}\text { FCO4- } \\
110\end{array}$ \\
\hline \multicolumn{15}{|l|}{ Angulogerina fluens } \\
\hline Ammodiscus gullmarensis* & & 0.01 & 0.00 & 0.00 & 0.01 & 0.00 & & 0.02 & 0.08 & 0.05 & & & & 0.04 \\
\hline \multicolumn{15}{|l|}{ Astrononion gallowayi* } \\
\hline \multicolumn{15}{|l|}{ Bolivima decussata } \\
\hline Bolivina mimuta* & & 0.00 & 0.01 & 0.01 & & & & & & & & & & \\
\hline Bolivinellina pacifica* & & & & 0.00 & & & & & & & & & & \\
\hline \multicolumn{15}{|l|}{ Botuloides pauciloculus } \\
\hline Buccella frigida* & 0.18 & 0.09 & 0.08 & 0.07 & & & & & & & & & & \\
\hline \multicolumn{15}{|l|}{ Buccella hamai } \\
\hline \multicolumn{15}{|l|}{ Buccella imusitata } \\
\hline Buccella tenerrima* & & & & 0.00 & & & & & & & & & & \\
\hline Buccella depressa & & & & 0.00 & & & & & & & & & & \\
\hline Buliminella elegantissima* & & & 0.00 & & & & & & & & & & & \\
\hline \multicolumn{15}{|l|}{ Cassidulinasp } \\
\hline Cassidulina crassa* & 0.04 & 0.00 & 0.01 & 0.05 & & & & & & & & & & \\
\hline \multicolumn{15}{|l|}{ Cribroelphidium excavatum* } \\
\hline C. excavatum f. magna* & 0.01 & 0.05 & 0.01 & 0.01 & & & & & & & & & & \\
\hline C. excavatum f. clavata* & 0.11 & 0.06 & 0.12 & 0.11 & & & & & & & & & & \\
\hline C. excavatum f. excavata* & 0.01 & 0.02 & 0.01 & 0.04 & & & & & & & & & & \\
\hline C. excavatum f. selseyensis* & 0.01 & 0.01 & & & & & & & & & & & & \\
\hline C. excavatum f. lidoensis & & & 0.00 & & & & & & & & & & & \\
\hline Cribroelphidium foraminosum ${ }^{*}$ & 0.01 & 0.02 & 0.02 & 0.05 & & & & & & & & & & \\
\hline Cribroelphidium hallandense* & & & & 0.00 & & & & & & & & & & \\
\hline \multicolumn{15}{|l|}{ Cribroelphidium magellanicum* } \\
\hline \multicolumn{15}{|l|}{ Cribroelphidium microgranulosum* } \\
\hline Cribrostomoides sp. $A^{*}$ & 0.02 & 0.03 & & 0.00 & & & & & & & & & 0.07 & 0.02 \\
\hline Cribrostomoides crassimargo* & & & & & 0.00 & & & & & & & & & \\
\hline Cribrostomoides jeffreysii ${ }^{*}$ & 0.05 & 0.01 & 0.02 & & 0.03 & 0.01 & 0.03 & 0.01 & & & 0.11 & 0.05 & & 0.01 \\
\hline Cribrostomoides subglobosum ${ }^{*}$ & 0.03 & 0.02 & 0.03 & 0.00 & 0.10 & 0.11 & 0.20 & 0.24 & 0.08 & 0.10 & 0.15 & 0.02 & 0.05 & 0.07 \\
\hline Cribrostomoides wiesneri* & & & & & & & 0.01 & & & & & & & 0.03 \\
\hline \multicolumn{15}{|l|}{ Dyocibicides biserialis } \\
\hline Eggerella advena* & 0.04 & 0.02 & 0.02 & 0.00 & 0.33 & 0.32 & 0.31 & 0.37 & 0.24 & 0.31 & 0.21 & 0.39 & 0.28 & 0.31 \\
\hline Eggerella whatever* & & & & & 0.33 & 0.33 & 0.15 & 0.12 & 0.31 & 0.30 & 0.27 & 0.27 & 0.14 & 0.22 \\
\hline Elphidiella hannai* & & & & & & & & & & & & & & \\
\hline Epistominella vitrea* & 0.01 & 0.02 & 0.05 & 0.03 & & & & & & & & & & \\
\hline Enuvigerina aculeata & & & 0.01 & 0.00 & & & & & & & & & & \\
\hline Eunvigerina peregrina* & 0.01 & 0.01 & & & & & & & & & & & & \\
\hline Favulina epibathra* & & & & & & & & & & & & & & \\
\hline Favulina melo & & & & & & & & & & & & & & \\
\hline Fissurina cucurbilasema & & & & 0.00 & & & & & & & & & & \\
\hline Fissurina eburnea* & & & & & & & & & & & & & & \\
\hline Fissurina lucida & & & 0.00 & & & & & & & & & & & \\
\hline Fissurina vitreola & & & & & & & & & & & & & & \\
\hline Gavelinopsis campanulata & & & & & & & & & & & & & & \\
\hline Gaudryina arenaria & & & & & 0.00 & & & & & & & & & \\
\hline Haplophragmoides brady* & 0.28 & 0.26 & 0.17 & 0.09 & & & & & & & 0.01 & & & \\
\hline Homalohedra apiopleura & & & & & & & & & & & & & & \\
\hline Homalohedra borealis & & & & & & & & & & & & & & \\
\hline Homalohedra gtuntherii & & & & & & & & & & & & & & \\
\hline Hyalinonetrion dentaliforme & & & & & & & & & & & & & & \\
\hline Islandiella sp. & & & & & & & & & & & & & & \\
\hline Islandiella helenae * & & & & & & & & & & & & & & \\
\hline Lagena sp. & & & & & & & & & & & & & & \\
\hline Lagena meridionalis & & & & & & & & & & & & & & \\
\hline Lagena laevis & & & & & & & & & & & & & & \\
\hline Lagena parri & & & & & & & & & & & & & & \\
\hline Lagena semilineata & & & & & & & & & & & & & & \\
\hline Laryngosigma trilocularis & & & & & & & & & & & & & & \\
\hline Lobatula fletcheri* & & 0.01 & & 0.00 & & & & & & & & & & \\
\hline Lobatula lobanla* & & & & & & & & & & & & & & \\
\hline Lobania mckannai* & 0.01 & & & 0.00 & & & & & & & & & & \\
\hline
\end{tabular}




\begin{tabular}{|c|c|c|c|c|c|c|c|c|c|c|c|c|c|c|}
\hline & FC04-70 & $\mathrm{FCO4-73}$ & $\mathrm{FCO4-75}$ & $F C 04-76$ & FC04-77 & $\mathrm{FC} 04-78$ & FC04-79 & FCO4-80 & $\begin{array}{l}\mathrm{FCO} 04- \\
86+87\end{array}$ & $\begin{array}{l}\mathrm{FC} 04 \\
88+89\end{array}$ & $\begin{array}{l}\text { FCOA- } \\
90^{\wedge} 93\end{array}$ & $\begin{array}{l}\text { FCOA- } \\
94^{\wedge} 97\end{array}$ & $\begin{array}{l}\text { FCO4- } \\
109\end{array}$ & $\begin{array}{l}\text { FC04- } \\
110\end{array}$ \\
\hline \multicolumn{15}{|l|}{ Miliammina fusca* } \\
\hline Miliammina sp. & & & & & & & & & & & & & 0.02 & \\
\hline \multicolumn{15}{|l|}{ Neouvigerima proboscidea* } \\
\hline Nonionella digitata & & & & 0.00 & & & & & & & & & & \\
\hline Nonionella stella* & 0.01 & 0.01 & & 0.01 & & & & & & & & & & \\
\hline \multicolumn{15}{|l|}{ Nonionella cf. turgida } \\
\hline $\begin{array}{c}\text { Nonionellina labradorica* } \\
\text { Palliolatella fragens }\end{array}$ & \multicolumn{14}{|c|}{ Palliolatella fragens } \\
\hline \multicolumn{15}{|l|}{ Palliolatella immemora } \\
\hline \multicolumn{15}{|l|}{ Parafissurina semicarinata } \\
\hline \multicolumn{15}{|l|}{ Procerolagena cf. amphora } \\
\hline $\begin{array}{c}\text { Procerolagena gracilis } \\
\text { Procerolagena mollis } \\
\text { Procerolagena wiesneri }\end{array}$ & & & 0.00 & & & & & & & & & & & \\
\hline $\begin{array}{c}\text { Protoglobulimina pupoides* } \\
\text { Pseudononion basispinata }\end{array}$ & 0.01 & 0.02 & 0.00 & 0.00 & & & & & & & & & & \\
\hline $\begin{array}{l}\text { Pygmaeoseistron hispidultum } \\
\text { Quinqueloculina sp. } \\
\text { Rosalina cohmbiensis* }\end{array}$ & & & 0.01 & 0.00 & & & & & & & & & & \\
\hline \multicolumn{15}{|l|}{ Reophax catella } \\
\hline \multicolumn{15}{|l|}{ Reophax cylindricus } \\
\hline \multicolumn{15}{|l|}{ Reophax gracilis } \\
\hline Reophax scottii & 0.01 & & & & & & & & & & & & & \\
\hline Saccammina atlantica & & & & & & & 0.02 & & & & & & & \\
\hline \multicolumn{15}{|l|}{ Saccammina sphaerica } \\
\hline Spiroplectammina biformis* & 0.01 & 0.00 & 0.00 & 0.00 & 0.04 & 0.05 & 0.05 & 0.05 & 0.11 & 0.08 & 0.08 & 0.05 & 0.02 & 0.14 \\
\hline Stainfor thia feylingi* & 0,06 & 0.25 & 0.32 & 0.44 & & & & & & & & & & \\
\hline \multicolumn{15}{|l|}{ Trochammina sp. } \\
\hline Trochammina charlottensis* & & 0.01 & & 0.00 & & 0.00 & & & 0.01 & & & & & \\
\hline Trochammina discorbis* & 0.01 & 0.01 & 0.01 & & 0.00 & 0.00 & 0.02 & & & & & & & \\
\hline Trochammina cf. globigeriniformis* & & & & & 0.00 & & & & & & & & & \\
\hline \multicolumn{15}{|l|}{ Trochammina grisea } \\
\hline Trochammina squamata & & & & & & & & & & & & 0.02 & & \\
\hline Trochammina narta* & & & 0.00 & & 0.01 & 0.02 & & & & & 0.01 & & & 0.02 \\
\hline \multicolumn{15}{|l|}{ Trochammina nitida } \\
\hline \multicolumn{15}{|l|}{ Trochammina ochracea } \\
\hline Trochammina pacifica & 0.01 & & 0.01 & 0.00 & 0.01 & 0.00 & 0.02 & & & & & & & 0.01 \\
\hline \multicolumn{15}{|l|}{ Trochammina rotaliformis } \\
\hline Planktonic sp. ${ }^{*}$ & & & 0.01 & & 0.02 & & & & & & & & & \\
\hline Thecamoebians** & 0.01 & 0.00 & 0.01 & & 0.01 & 0.01 & & 0.04 & 0.03 & 0.11 & 0.01 & 0.14 & 0.19 & 0.05 \\
\hline Total Counts & 140 & 290 & 289 & 512 & 416 & 272 & 110 & 113 & 74 & 88 & 73 & 44 & 43 & 114 \\
\hline
\end{tabular}




\begin{tabular}{|c|c|c|c|c|c|c|c|}
\hline & $\begin{array}{l}\mathrm{FCO4-} \\
112^{\wedge} 116\end{array}$ & $\begin{array}{c}\mathrm{FCO4-} \\
118\end{array}$ & $\begin{array}{c}\mathrm{FC} 04- \\
121\end{array}$ & $\begin{array}{c}\mathrm{FCO} 4- \\
123\end{array}$ & $\begin{array}{c}\mathrm{FC} 04- \\
124\end{array}$ & $\begin{array}{c}\mathrm{FC} 04- \\
132\end{array}$ & $\begin{array}{c}\mathrm{FC} 04- \\
138\end{array}$ \\
\hline \multicolumn{8}{|l|}{ Angulogerina fluens } \\
\hline Ammodiscus gullmarensis* & 0.08 & 0.03 & 0.04 & 0.03 & & & \\
\hline \multicolumn{8}{|l|}{ Astrononion gallowayi* } \\
\hline \multicolumn{8}{|l|}{ Bolivina decussata } \\
\hline \multicolumn{8}{|l|}{ Bolivina minuta* } \\
\hline \multicolumn{8}{|l|}{ Bolivinellina pacifica* } \\
\hline \multicolumn{8}{|l|}{ Botuloides paucilocuhus } \\
\hline \multicolumn{8}{|l|}{ Buccella frigida* } \\
\hline \multicolumn{8}{|l|}{ Buccella hannai } \\
\hline \multicolumn{8}{|l|}{ Buccella imusitata } \\
\hline \multicolumn{8}{|l|}{ Buccella tenerrima* } \\
\hline \multicolumn{8}{|l|}{ Buccella depressa } \\
\hline \multicolumn{8}{|l|}{ Buliminella elegantissima* } \\
\hline \multicolumn{8}{|l|}{ Cassidulina sp. } \\
\hline \multicolumn{8}{|l|}{ Cassidulina crassa* } \\
\hline Cribroelphidium excavattm ${ }^{*}$ & & & & & & & \\
\hline C. excavatumf. magna* & & & & & & & \\
\hline C. excavatum f clavata* & & & & & & & \\
\hline C. excavatum f. excavata* & & & & & & & \\
\hline C. excavatum f. selseyensis* & & & & & & & \\
\hline C. excavatum f. lidoensis & & & & & & & \\
\hline Cribroelphidium foraminosum * & & & & & & & \\
\hline Cribroelphiditum hallandense* & & & & & & & \\
\hline Cribroelphidium magellanicum ${ }^{*}$ & & & & & & & \\
\hline Cribroelphidium microgranulosum * & & & & & & & \\
\hline Cribrostomoides sp. $A^{*}$ & 0.07 & & & & 0.03 & & \\
\hline Cribrostomoides crassimargo* & & 0.01 & 0.04 & 0.03 & 0.02 & 0.03 & 0.01 \\
\hline Cribrostomoides jeffreysii ${ }^{*}$ & 0.02 & 0.03 & & 0.02 & & & 0.04 \\
\hline Cribrostomoides subglobosum* & 0.05 & 0.01 & & 0.17 & 0.12 & 0.07 & 0.02 \\
\hline Cribrostomoides wiesneri* & & & & & & & \\
\hline Dyocibicides biserialis & & & & & & & \\
\hline Eggerella advena* & 0.31 & 0.35 & 0.33 & 0.24 & 0.47 & 0.22 & 0.16 \\
\hline Eggerella whatever* & 0.27 & 0.28 & 0.35 & 0.33 & 0.19 & 0.28 & 0.20 \\
\hline Elphidiella hannai* & & & & & & & \\
\hline Epistominella vitrea* & & & & & & & \\
\hline Eutvigerina aculeata & & & & & & & \\
\hline Eutvigerina peregrina* & & & & & & & \\
\hline Favwina epibathra* & & & & & & & \\
\hline Favulina melo & & & & & & & \\
\hline Fissurina cucurbitasema & & & & & & & \\
\hline Fissuring eburnea* & & & & & & & \\
\hline Fissurina lucida & & & & & & & \\
\hline Fissurina vitreola & & & & & & & \\
\hline Gavelinopsis campantala & & & & & & & \\
\hline Gandryina arenaria & & 0.01 & & & & & \\
\hline Haplophragmoides brady* & & & & & 0.01 & & 0.01 \\
\hline Homalohedra apiopleura & & & & & & & \\
\hline Homalohedra borealis & & & & & & & \\
\hline Homalohedra gumtherii & & & & & & & \\
\hline Hyalinonetrion dentaliforme & & & & & & & \\
\hline Istandiella sp. & & & & & & & \\
\hline Islandiella helenae* & & & & & & & \\
\hline Lagena sp. & & & & & & & \\
\hline Lagena meridionalis & & & & & & & \\
\hline Lagena laevis & & & & & & & \\
\hline Lagena parri & & & & & & & \\
\hline Lagena semilineata & & & & & & & \\
\hline Laryngosigma trilocularis & & & & & & & \\
\hline Lobatula fletcheri ${ }^{*}$ & & & & & & & \\
\hline Lobatula lobatula* & & & & & & & \\
\hline Lobatula mckamnai* & & & & & & & \\
\hline
\end{tabular}




\begin{tabular}{|c|c|c|c|c|c|c|c|}
\hline & $\begin{array}{c}\text { FCO4- } \\
112^{\wedge} 116\end{array}$ & $\begin{array}{c}\text { FC04- } \\
118\end{array}$ & $\begin{array}{c}\mathrm{FCO} 4- \\
121\end{array}$ & $\begin{array}{c}\mathrm{FCO4-} \\
123\end{array}$ & $\begin{array}{c}\mathrm{FCO} 4- \\
124\end{array}$ & $\begin{array}{c}\mathrm{FC} 04- \\
132\end{array}$ & $\begin{array}{c}\text { FC04- } \\
138\end{array}$ \\
\hline \multicolumn{8}{|l|}{ Miliammina fusca* } \\
\hline \multicolumn{8}{|l|}{ Miliammina sp. } \\
\hline \multicolumn{8}{|l|}{ Neouvigerina proboscidea* } \\
\hline \multicolumn{8}{|l|}{ Nonionella digitata } \\
\hline \multicolumn{8}{|l|}{ Nonionella stella* } \\
\hline \multicolumn{8}{|l|}{ Nonionella cf. turgida } \\
\hline \multicolumn{8}{|l|}{ Nonionellina labradorica ${ }^{*}$} \\
\hline \multicolumn{8}{|l|}{ Palliolatella fragens } \\
\hline \multicolumn{8}{|l|}{ Palliolatella immemora } \\
\hline \multicolumn{8}{|l|}{ Parafissurina semicarinata } \\
\hline Portatrachammina bipolaris* & & 0.01 & & & 0.01 & 0.02 & \\
\hline \multicolumn{8}{|l|}{ Procerolagena cf. amphora } \\
\hline \multicolumn{8}{|l|}{ Procerolagena gracilis } \\
\hline \multicolumn{8}{|l|}{ Procerolagena mollis } \\
\hline \multicolumn{8}{|l|}{ Procerolagena wiesneri } \\
\hline \multicolumn{8}{|l|}{ Protoglobulimina pupoides* } \\
\hline \multicolumn{8}{|l|}{ Pseudononion basispinata } \\
\hline \multicolumn{8}{|l|}{ Pygmaeoseistron hispidulum } \\
\hline \multicolumn{8}{|l|}{ Quimqueloculina sp. } \\
\hline \multicolumn{8}{|l|}{ Rosalina columbiensis* } \\
\hline Recurvoides turbinatus* & 0.11 & 0.11 & 0.13 & 0.06 & 0.07 & 0.22 & 0.08 \\
\hline Reophax catella & & & & & & & 0.01 \\
\hline Reophax cylindricus & & & & & & & 0.01 \\
\hline Reophax gracilis & 0.02 & & & & 0.02 & & \\
\hline \multicolumn{8}{|l|}{ Reophax scotiii } \\
\hline \multicolumn{8}{|l|}{ Saccammina atlantica } \\
\hline \multicolumn{8}{|l|}{ Saccammina sphaerica } \\
\hline Spiroplectammina biformis* & & 0.07 & 0.09 & 0.05 & 0.05 & 0.10 & 0.11 \\
\hline Stainfor thia feylingi* & & & & & & & 0.05 \\
\hline \multicolumn{8}{|l|}{ Textularia earlandi* } \\
\hline Trochammina sp. & & 0.01 & & & & & \\
\hline Trochammina charlottensis* & & 0.03 & 0.02 & 0.02 & & & \\
\hline Trochammina discorbis* & & & & & & & \\
\hline Trochammina cf. globigurimformi & & & & & & & \\
\hline Trochammina grisea & & & & & & & \\
\hline Trochammina squamata & & & & & & & \\
\hline Trochammina nana* & & 0.01 & & & 0.02 & & 0.02 \\
\hline Trochammina nitida & & & & & & & \\
\hline Trochammina ochracea & & & & & & & \\
\hline Trochammina pacifica & 0.02 & 0.01 & & & & & \\
\hline Trochammina rotaliformis & & & & & & & \\
\hline Planktonic sp. ${ }^{*}$ & & & & & & & \\
\hline Thecamoebians* & 0.04 & 0.05 & & 0.06 & & 0.05 & 0.27 \\
\hline Total Coumts & 91 & 148 & 46 & 66 & 123 & 58 & 83 \\
\hline
\end{tabular}




\begin{abstract}
APPENDIX B
AMS radiocarbon dates from core $\mathrm{FC} 04$. The following are copies of the original reports supplied by Dr. Rolf Beukens of IsoTrace Laboratories (Toronto, ON).
\end{abstract}




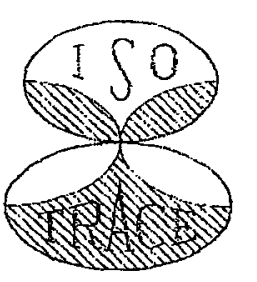

ISOTRACE Laboratory Accelerator Mass Spectrometry Facility at the University of Toronto

From: Alice W. C. Leung Business Officer

Send to: Prof. R. Timothy Patterson

Dept. of Earth Sciences

Carleton University

$$
2569
$$

FAX No: $\quad 613-520-440$

Number of pages including this page.
IsoTrace Laboratory 60 St. George Street

Toronto, Ontario

Canada. M5S 1A7

Telephone

(416) 9782258

Email alice.leung@utoronto.ca

Fax (416) 9784711
Date:

1 
IsoTrace Radiocarbon Laboratory

Accelerator Mass Spectrometry Facility at the University of Toronto
60 St. George Street Toronto (Ont) Canada M5S 1A7

Telephone: $416-978-4628$

Fax: $416-978-4711$

Email: roelf.beukens@utoronto.ca

\section{Radiocarbon Analysis Report}

January 26,2006

Submitter: R.T.Patterson, Dept of Earth Sciences, Carleton Univ, Ottawa ON

These results are the average of 2 separate analyses (normal precision) and are corrected for natural and sputtering isotope fractionation, using the measured ${ }^{13} \mathrm{C} /{ }^{12} \mathrm{C}$ ratios. The sample ages are quoted as uncalibrated conventional radiocarbon dates in years before present (BP), using the Libby ${ }^{14} \mathrm{C}$ meanlife of 8033 years. The errors represent $68.3 \%$ confidence limits.

\begin{tabular}{llccr}
$\begin{array}{l}\text { Sample } \\
\text { Identification }\end{array}$ & Description & $\begin{array}{c}\text { Weight } \\
\text { used }(\mathrm{mg})\end{array}$ & $\begin{array}{c}\text { IsoTrace } \\
\text { Lab number }\end{array}$ & $\begin{array}{c}\text { Age } \\
\text { (years BP) }\end{array}$ \\
\hline FC04.77 & wood & 15 & TO-12566 & $530 \pm 40$ \\
* FC04.J5 & gyttja & 4000 & TO-12567 & $1060 \pm 50$ \\
TL136 & gyttja & 3200 & TO-12568 & $8740 \pm 70$ \\
TL160 & gyttja & 745 & TO-12569 & $8840 \pm 60$ \\
\hline
\end{tabular}

I would like to hear your comments on these results. If these results are used in a publication, I would appreciate it if you could send me a reprint.

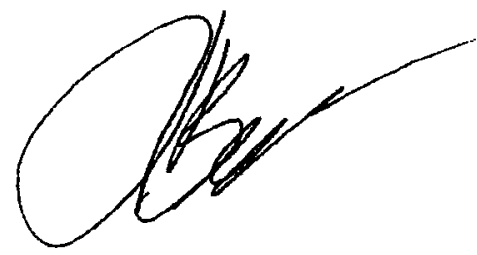

Dr. R. P. Beukens 
ISOTRACE RADIOCARBON CALIBRATION REPORT

output by calibration program C14CAL04

Copyright (c) R.P.Beukens

$$
\text { 26-Jan-06 }
$$

TO-12566 FC04.77 wood

Radiocarbon date : $530 \pm 40 \mathrm{BP}$

All solutions, with a probability of $50 \%$ or greater for the calibrated age of this radiocarbon date, have been calculated from the dendro calibration data. The $68 \%$ and $95 \%$ confidence intervals, which are the $1 \sigma$ and $2 \sigma 1$ imits for a normal distribution, are also given. A probability of $100 \%$ means the radiocarbon date intersects the dendro calibration curve at this age. All results are rounded to the nearest multiple of 5 years.

\begin{tabular}{cccc} 
Probability & cal Age & $68.3 \%$ c.i. & $95.5 \%$ c.i. \\
\hline $100 \frac{\circ}{6}$ & $1410 \mathrm{cal} A D$ & $1400 \mathrm{AD}-1430 \mathrm{AD}$ & $1385 \mathrm{AD}-1440 \mathrm{AD}$
\end{tabular}

\footnotetext{
Calibrated with the standard data set from: INTCAL04 Terrestrial Radiocarbon Age Calibration, 0-26 cal kyr BP P.J.Reimer et al.; Radiocarbon 46\#3 (2004) p1029
}

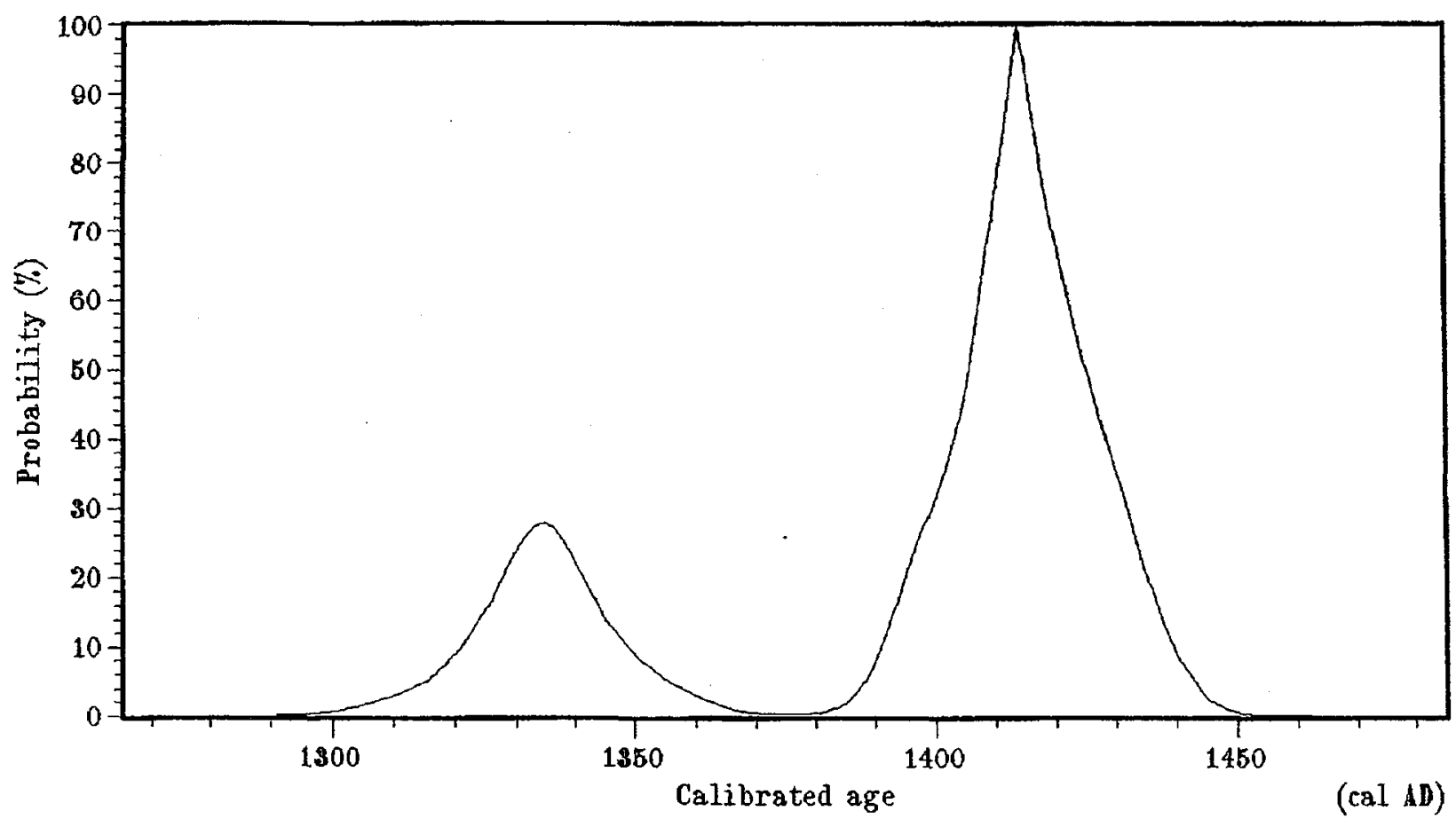

Reproduced with permission of the copyright owner. Further reproduction prohibited without permission. 
ISOTRACE RADIOCARBON CALIBRATION REPORT

Output by calibration program C14CAL04

Copyright (c) R.P.Beukens

$$
\text { 26-Jan-06 }
$$

TO-12567 FCO4.J5 gyttja

Radiocarbon date : $1060 \pm 50 \mathrm{BP}$

All solutions, with a probability of $50 \%$ or greater for the calibrated age of this radiocarbon date, have been calculated from the dendro calibration data. The $68 \%$ and $95 \%$ confidence intervals, which are the $1 \sigma$ and $2 \sigma$ limits for a normal distribution, are also given. A probability of $100 \%$ means the radiocarbon date intersects the dendro calibration curve at this age. All results are rounded to the nearest multiple of 5 years.

$\begin{array}{llll}\text { Probability } & \text { cal Age } & 68.3 \% \text { c.i. } & 95.5 \% \text { c.i. } \\ 100 \text { 의 } & 990 \mathrm{cal} A D & 965 \mathrm{AD}-1020 \mathrm{AD} & 885 \mathrm{AD}-1035 \mathrm{AD}\end{array}$

Calibrated with the standard data set from:

INTCAL04 Terrestrial Radiocarbon Age Calibration, 0-26 cal kyr BP P.J.Reimer et al.; Radiocarbon $46 \# 3$ (2004) p1029

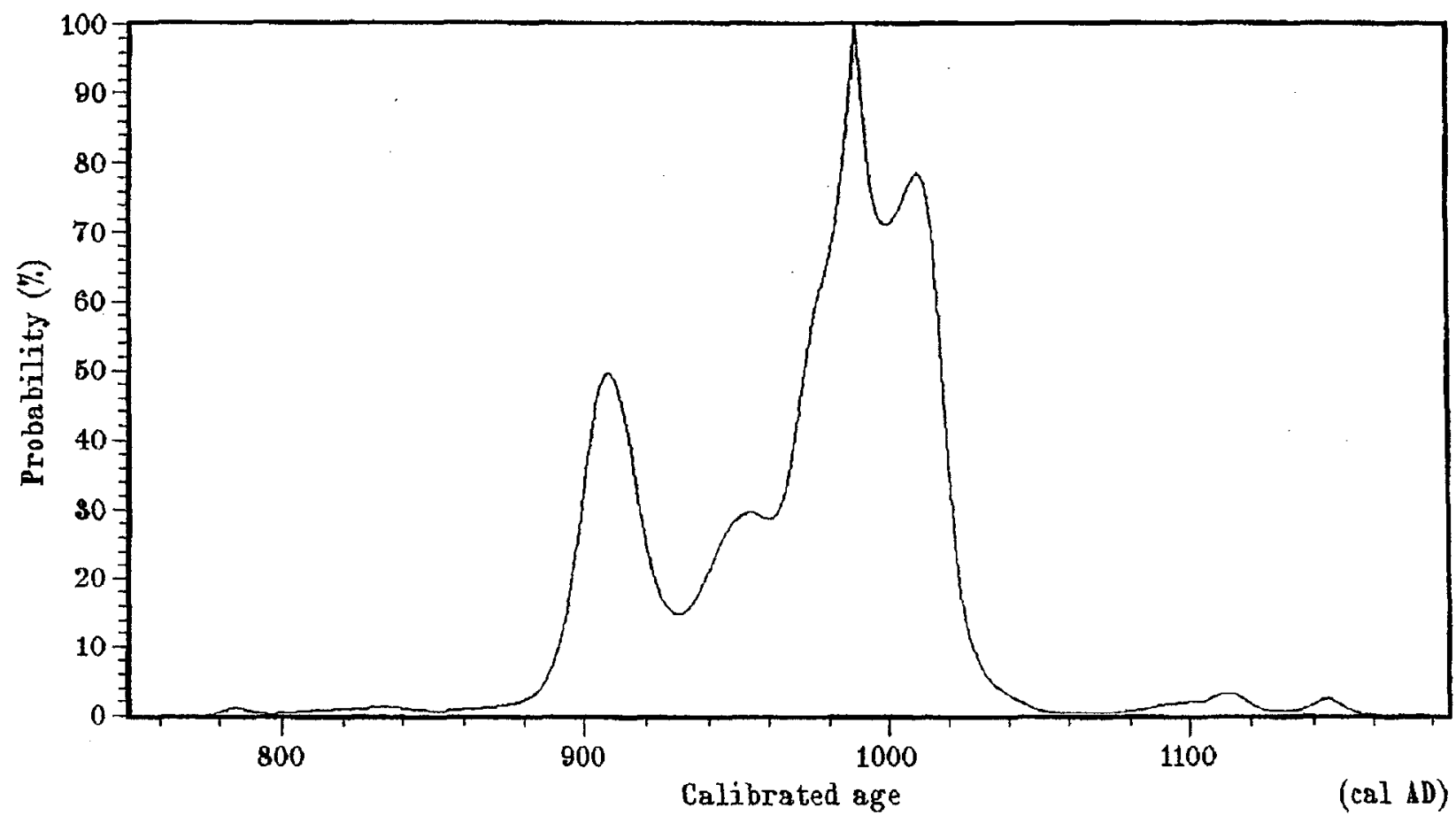

Reproduced with permission of the copyright owner. Further reproduction prohibited without permission. 
ISOTRACE RADIOCARBON CALIBRATION REPORT

Output by calibration program C14CALO4

Copyright (c) R.P.Beukens

$$
\text { 26-Jan-06 }
$$

TO-12568 TLI36 gyttja

Radiocarbon date : $8740 \pm 70 \mathrm{BP}$

All solutions, with a probability of 50\% or greater for the calibrated age of this radiocarbon date, have been calculated from the dendro calibration data. The $68 \%$ and $95 \%$ confidence intervals, which are the $1 \sigma$ and $2 \sigma$ limits for a normal distribution, are also given. A probability of $100 \%$ means the radiocarbon date intersects the dendro calibration curve at this age. All results are rounded to the nearest multiple of 5 years.

\begin{tabular}{cccc} 
Probability & cal Age & 68.3 \%.i. & 95.5 \%.i. \\
\hline $100 \%$ & $7745 \mathrm{cal} \mathrm{BC}$ & $7940 \mathrm{BC}-7605 \mathrm{BC}$ & $7990 \mathrm{BC}-7590 \mathrm{BC}$
\end{tabular}

\footnotetext{
Calibrated with the standard data set from: INTCAL04 Terrestrial Radiocarbon Age Calibration, 0-26 cal kyr BP P.J.Reimer et al.; Radiocarbon $46 \# 3$ (2004) p1029
}

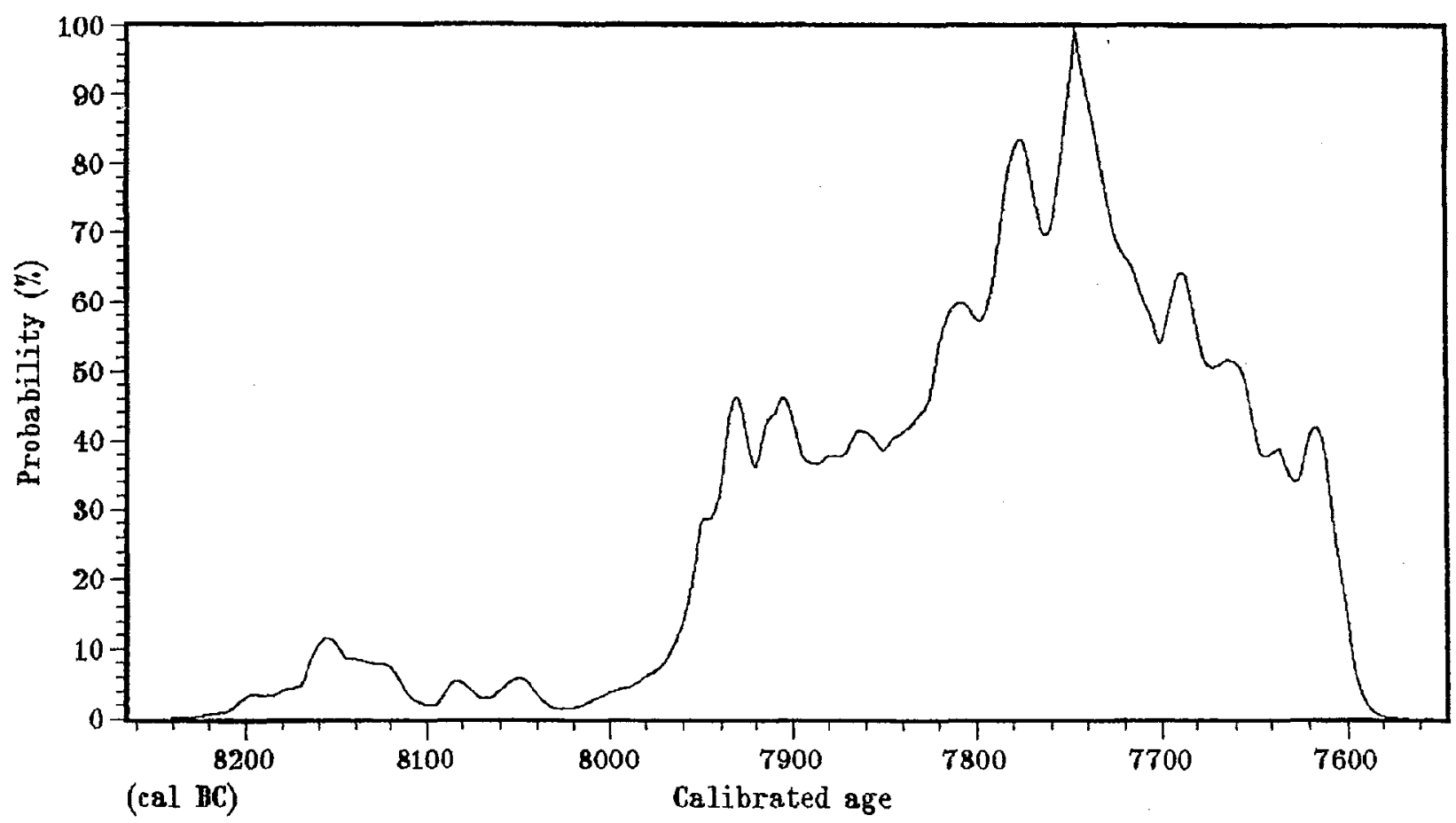

Reproduced with permission of the copyright owner. Further reproduction prohibited without permission. 
ISOTRACE RADIOCARBON CALIBRATION REPORT

output by calibration program C14CAL04

$$
\text { Copyright (c) R.P.Beukens }
$$

26-Jan-06

T0-12569 TL160 gyttja

Radiocarbon date : $8840 \pm 60 \mathrm{BP}$

All solutions, with a probability of 50 or or greater for the calibrated age of this radiocarbon date, have been calculated from the dendro calibration data. The $68 \%$ and $95 \%$ confidence intervals, which are the $1 \sigma$ and $2 \sigma$ limits for a normal distribution, are also given. A probability of 100 means the radiocarbon date intersects the dendro calibration curve at this age.

All reaults axe counded to the nearest multiple of 5 years.

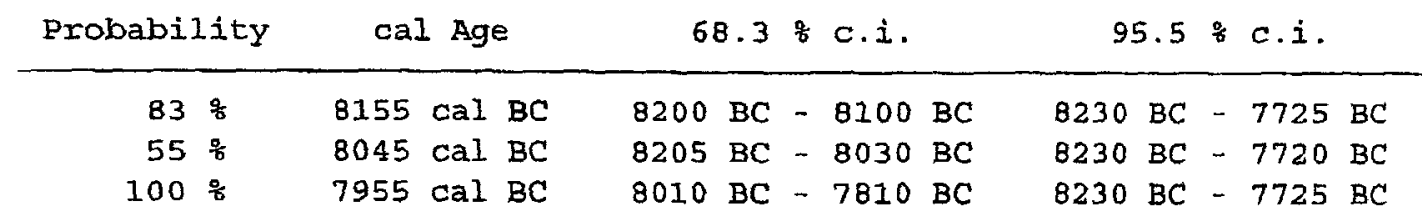

Calibrated with the standard data set from:

INTCAL04 Terrestrial Radiocarbon Age Calibration, 0-26 cal kyr BP P.J.Reimer et al.; Radiocarbon $46 \# 3$ (2004) p1029

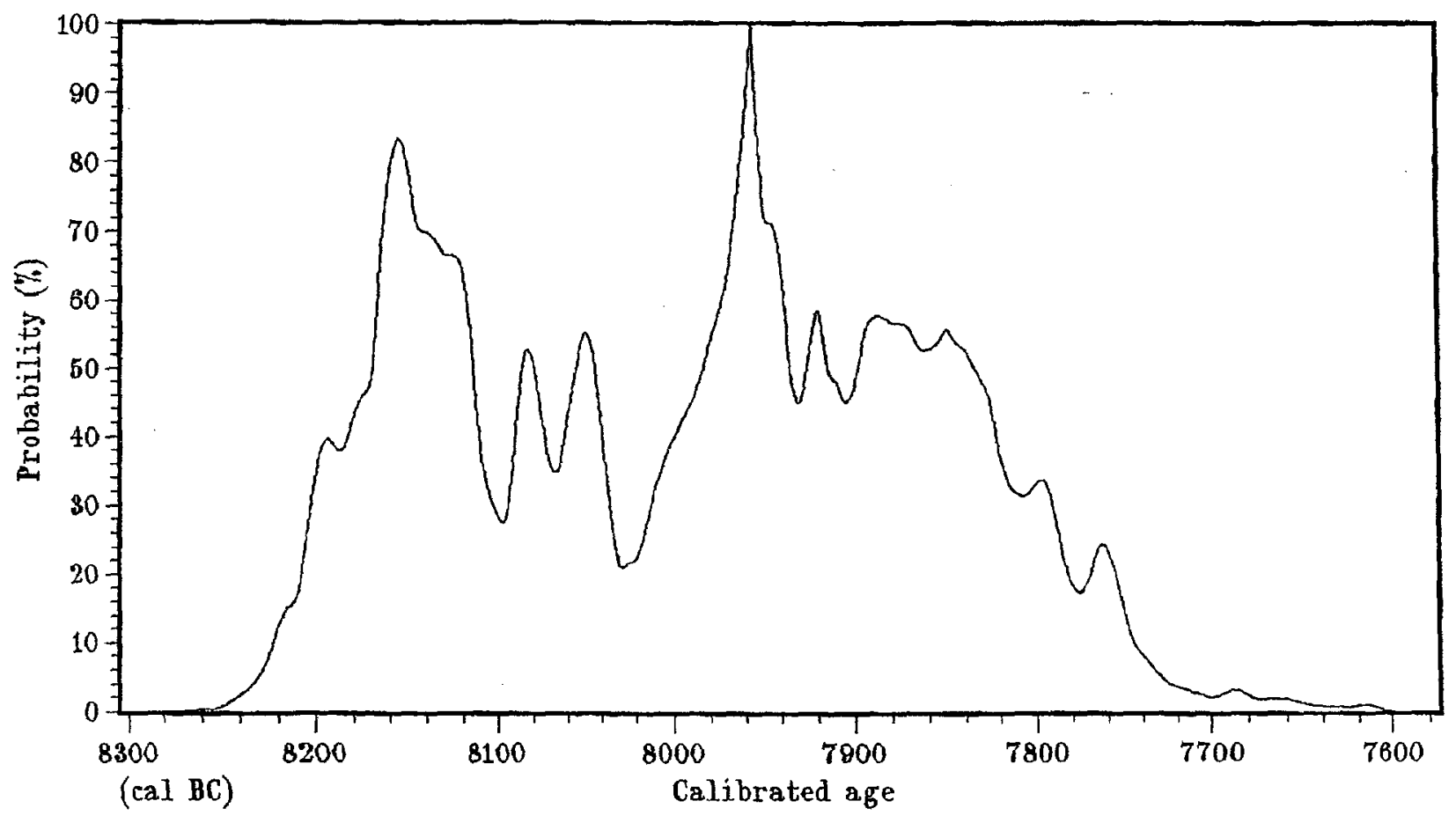

Reproduced with permission of the copyright owner. Further reproduction prohibited without permission. 
ISOTRACE RADIOCARBON CALIBRATION SUMMARY

Output by calibration program C14CALO4

Copyright (c) R.P.Beukens

$$
\text { 26-Jan-06 }
$$

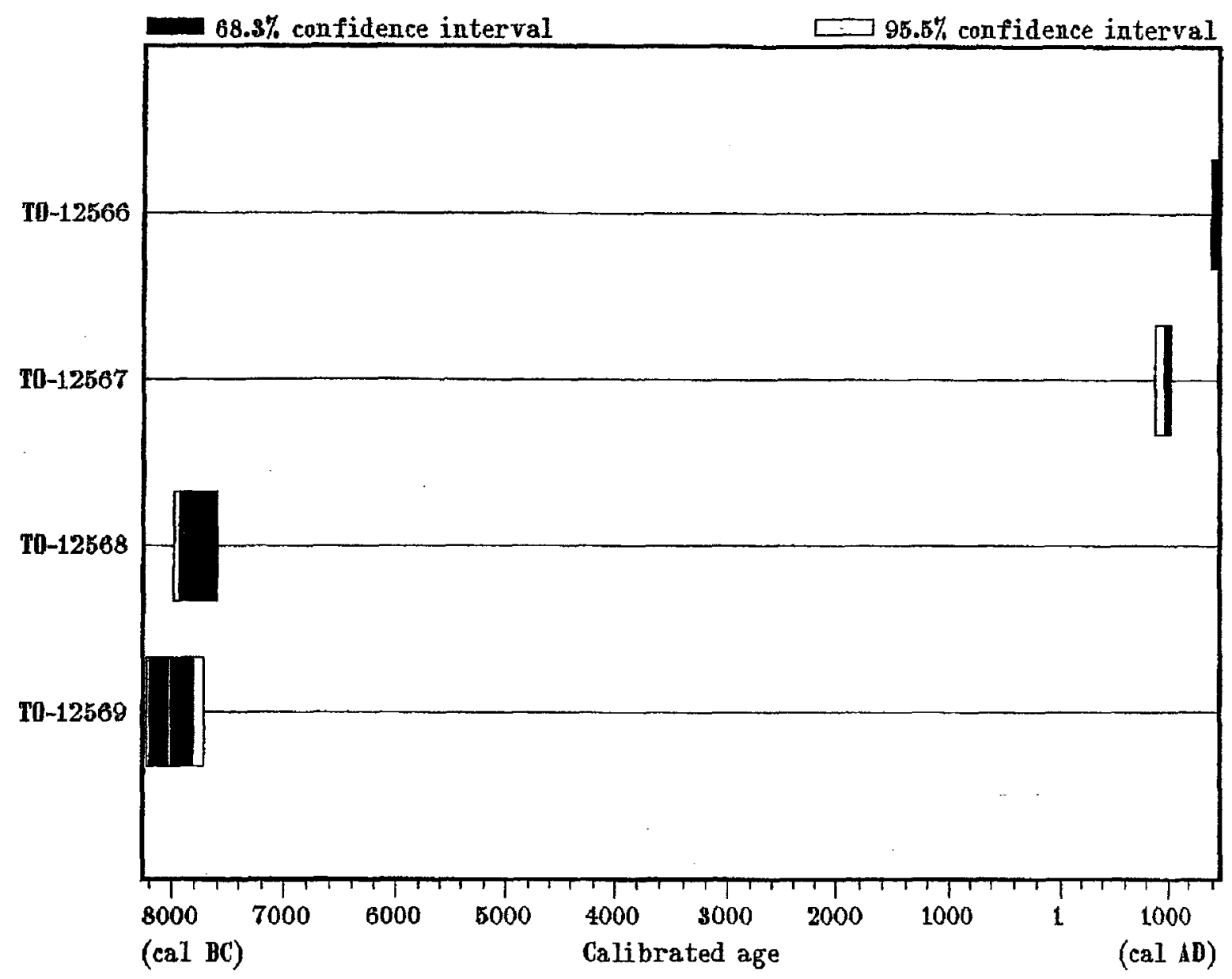

